UCRL-ID-113867-03

\title{
LLNL NESHAPs 2002 Annual Report
}

R. J. Harrach, G. N., Gallegos, S.-R. Peterson, P. J. Tate, N. A. Bertoldo, K. R. Wilson, P. E. Althouse, J. M. Larson

\section{June 1, 2003}

Lawrence

Livermore

National

Laboratory 
This document was prepared as an account of work sponsored by an agency of the United States Government. Neither the United States Government nor the University of California nor any of their employees, makes any warranty, express or implied, or assumes any legal liability or responsibility for the accuracy, completeness, or usefulness of any information, apparatus, product, or process disclosed, or represents that its use would not infringe privately owned rights. Reference herein to any specific commercial product, process, or service by trade name, trademark, manufacturer, or otherwise, does not necessarily constitute or imply its endorsement, recommendation, or favoring by the United States Government or the University of California. The views and opinions of authors expressed herein do not necessarily state or reflect those of the United States Government or the University of California, and shall not be used for advertising or product endorsement purposes.

This work was performed under the auspices of the U.S. Department of Energy by University of California, Lawrence Livermore National Laboratory under Contract W-7405-Eng-48. 


\section{Environmental Protection Department} Operations and Regulatory Affairs Division

\section{LLNL NESHAPs 2002 Annual Report}

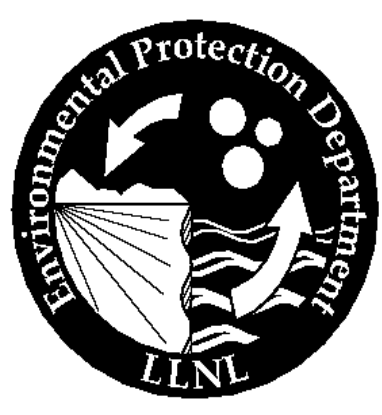

Lawrence Livermore National Laboratory

University of California Livermore, California 94551 


\section{LLNL NESHAPs 2002 Annual Report}

Robert J. Harrach

Gretchen M. Gallegos Sylvie-Ring Peterson

Paula J. Tate

Nicholas A. Bertoldo

Kent R. Wilson

Paris E. Althouse

Jennifer M. Larson

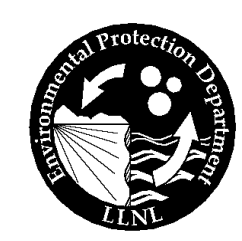

Contributors:

Donald H. MacQueen Judy L. Kelly Brent Bowen 


\section{U.S. Department of Energy \\ Radionuclide Air Emission Annual Report \\ (under Subpart H of 40 CFR Part 61) \\ Calendar Year 2002}

Site Name: $\quad$ Lawrence Livermore National Laboratory

\section{Operations Office Information}

Office: $\quad$ U.S. Department of Energy

Livermore Site Office

Address: $\quad 7000$ East Avenue, L-293

Livermore, CA 94550

Contact: Vijay Mishra Phone: 925-423-8163

\section{Site Information}

Operator: University of California

Address: $\quad 7000$ East Avenue

Livermore, CA 94551

Contact: C. Susi Jackson Phone: 925-423-6577 


\section{Table of Contents}

SYNOPSIS

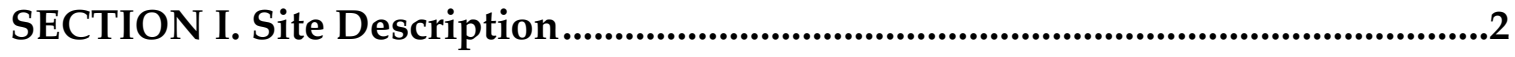

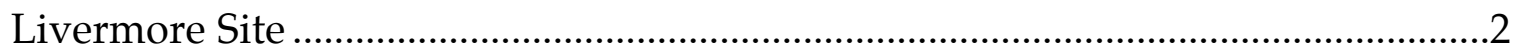

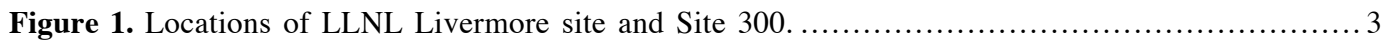

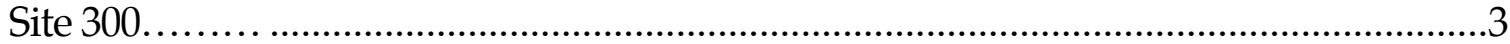

Figure 2. Wind rose showing the average annual wind speed, frequency of occurrence, and direction at the Livermore site, 2001.

Figure 3. Wind rose showing the average annual wind speed, frequency of occurrence, and direction at Site 300,2001 ......

SECTION II. Air Emission Sources and Data .................................................................6

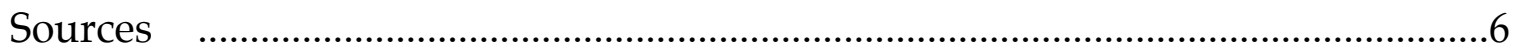

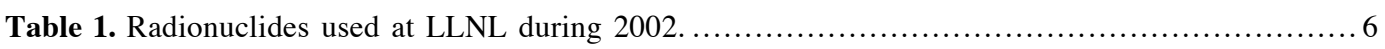

2001 Air Monitoring..............................................................................

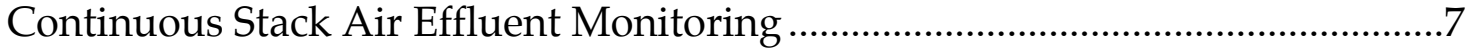

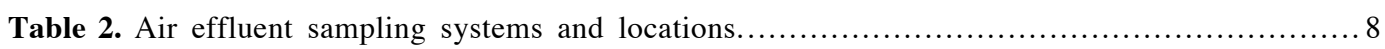

Results of stack monitoring for tritium .................................................8

Figure 4. Combined HT and HTO emissions from the Tritium Facility, 1981-2002,

distinguishing between chronic releases during normal operations (black bars) and acute accidental releases (gray bars). Accidental releases are predominantly HT gas.......................9

Stack monitoring for gross alpha and gross beta radiation ..................................

Air Surveillance Monitoring for Radioactive Particles and Gases.........................10

Radionuclide Usage Inventory Update.....................................................................11

SECTION III. Dose Assessment Methods and Concepts............................................12

Description of the Air Dispersion and Dose Model ...................................................12

Summary of Model Input Parameters .....................................................................12

General model inputs ....................................................................................12

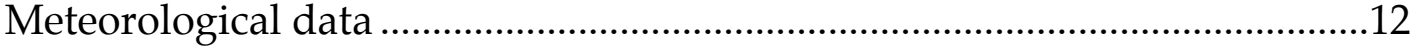

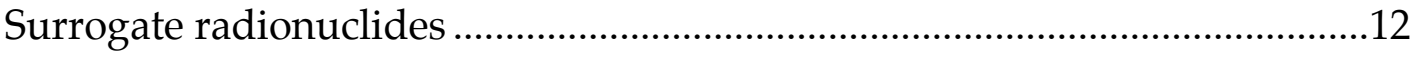

Population inputs ..........................................................................................13

Land use and agricultural inputs.....................................................................13

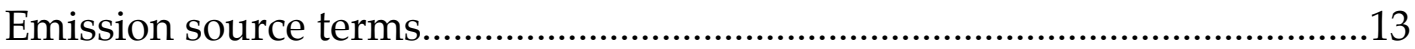

Table 3. List of materials exempted from the "treat as a gas above $100^{\circ} \mathrm{C}$ " rule, and temperatures

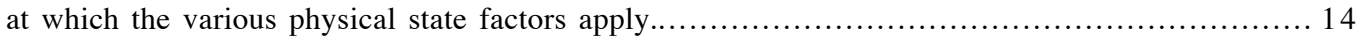

Site-wide maximally exposed individual ...........................................14

Figure 5. Location of site-wide maximally exposed individual (SW-MEI) at the

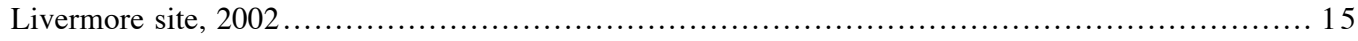

Maximally exposed public individual......................................................15 
Figure 6. Location of site-wide maximally exposed individual (SW-MEI) at Site 300, 2002 „....... 16

Special Modeling Challenges................................................................16

Site 300 explosives experiments ............................................................16

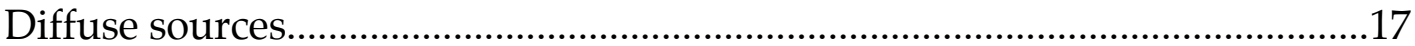

Modeling Documentation .........................................................................17

SECTION IV. Results of 2002 Radiological Dose Assessment.............................18

Total Dose to Site-Wide Maximally Exposed Individuals...................................18

Doses from Unplanned Releases ..................................................................18

Table 4. List of facilities or sources whose emissions accounted for more than $90 \%$ of the SW-MEI

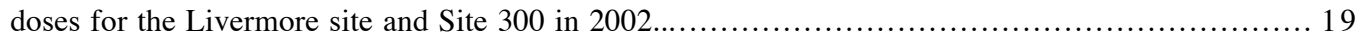

Population Doses...............................................................................19

Table 5. Doses (in mrem) calculated for the site-wide maximally exposed individual (SW-MEI)

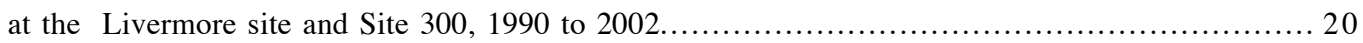

Compliance with 40 CFR 61 Subpart H (61.93) ...........................................20

SECTION V. Certification.......................................................................................22

\section{SECTION VI. Supplemental Information on NESHAPs Compliance and}

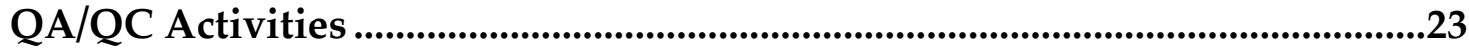

Requirements Under New EPA Standard for Stack Sampling.........................23

Table 6. Livermore site and Site 300 stack sampling systems that must satisfy the maintenance and inspection requirements in the ANSI N13.1-1999 standard...................................... 23

Periodic Confirmatory Measurements .........................................................24

Proposal to EPA for Use of Surveillance Air Monitoring in Demonstrating NESHAPs Compliance for LLNL's Numerous Minor Sources...........................24

NESHAPs Quality Assurance (QA) Program....................................................24

Quality Control (QC) for 2002 Radiological Usage Inventory and Modeling ...25

\section{SECTION VII. Supplementary Information on Radiological Dose Assessment}

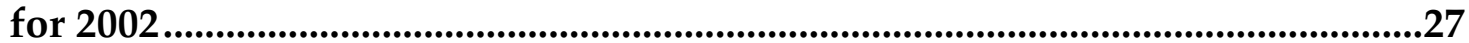

Livermore Site Principal Diffuse Sources.........................................................27

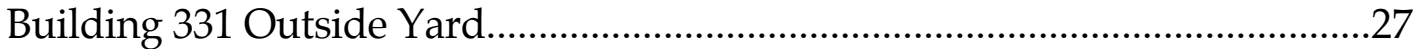

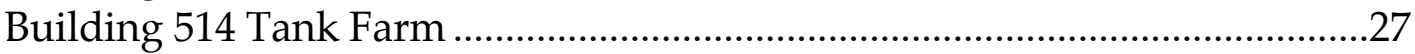

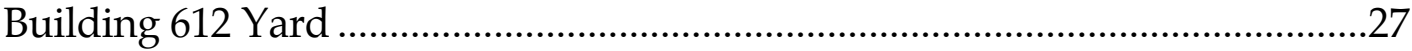

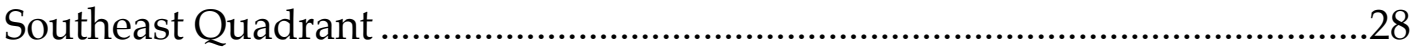

Site 300 Principal Diffuse Sources..................................................................28

Tritium Evaporation and Migration at Site 300 ............................................28

Resuspension of Depleted Uranium in Soil at Site 300 ................................29

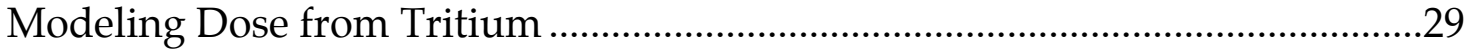

Comparison of 2002 Modeling Results with Tritium Surveillance

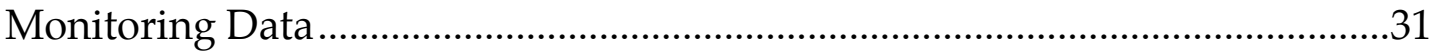

Figure 7. Tritiated water vapor surveillance sampling locations, Livermore site.................... 32 
LLNL NESHAPs Report 2002

Table 7. Comparison of measured and modeled annual mean concentrations of tritiated water

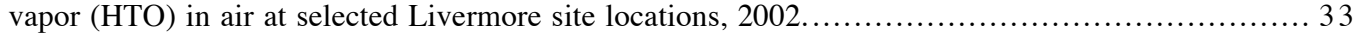

SECTION VIII. Supplemental Information on Other Compliance.........................34

Status of Compliance with Other Regulations..........................................................34

Status of Compliance with 40 CFR 61 Subpart Q - National Emission

Standards for Radon Emissions from Department of Energy Facilities.....34

Status of Compliance with 40 CFR 61 Subpart T - National Emission

Standards for Radon Emissions from the Disposal of Uranium

Mill Tailings ...........................................................................................................34

Information on Radon-220 and Radon-222 Emissions .......................................34

Attachment 1. LLNL NESHAPs 2002 Annual Report Spreadsheet ..........................35

Guidance for Interpreting the Data Spreadsheet .......................................................35

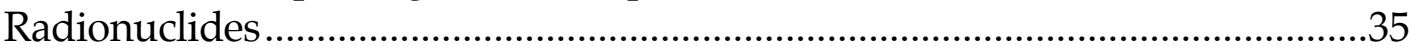

Radionuclide Usage Inventories with Potential for Release.............................35

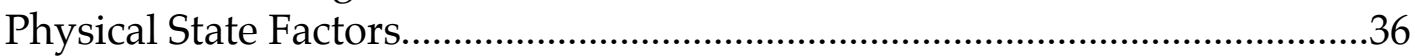

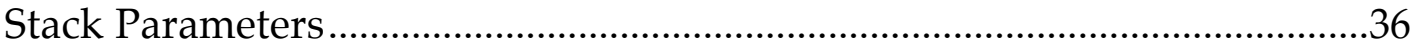

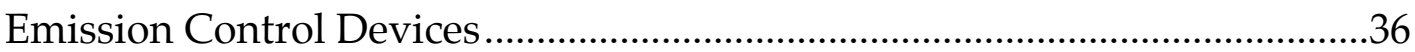

Control Device Abatement Factors.....................................................................36

Estimated Annual Emissions ……………………….........................................36

$10 \mathrm{mrem} / \mathrm{y}$ Site-Wide Dose Requirement..........................................................37

$0.1 \mathrm{mrem} / \mathrm{y}$ Monitoring Requirement .............................................................37

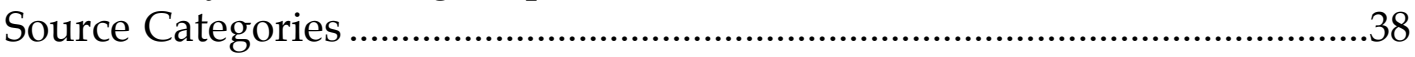

Attachment 2. Surrogate Radionuclides List ..................................................................59

Table 2-1. List of surrogate radionuclides.

60

Attachment 3. Content and Outcome of Proposal to EPA for Use of Air

Monitoring in Demonstrating NESHAPs Compliance for Minor Sources .....61 


\section{Lawrence Livermore National Laboratory NESHAPs 2002 Annual Report}

This annual report is prepared pursuant to the National Emission Standards for Hazardous Air Pollutants (NESHAPs; Title 40 Code of Federal Regulations [CFR] Part 61, Subpart H). Subpart H governs radionuclide emissions to air from Department of Energy (DOE) facilities.

\section{SYNOPSIS}

NESHAPs limits the emission of radionuclides to the ambient air from DOE facilities to levels resulting in an annual effective dose equivalent (EDE) of 10 mrem $(100 \mu \mathrm{Sv})$ to any member of the public. The EDEs for the Lawrence Livermore National Laboratory (LLNL) site-wide maximally exposed members of the public from operations in 2002 are summarized here.

- $\quad$ Livermore site: 0.023 mrem $(0.23 \mu \mathrm{Sv})$ (43\% from point-source emissions, $57 \%$ from diffuse-source emissions). The point-source emissions include gaseous tritium modeled as tritiated water vapor as directed by EPA Region IX; the resulting dose is used for compliance purposes.

- $\quad$ Site 300: $0.021 \mathrm{mrem}(0.21 \mu \mathrm{Sv})(85 \%$ from point-source emissions, $15 \%$ from diffuse-source emissions).

The EDEs were calculated using the EPA-approved CAP88-PC air dispersion/doseassessment model, except for doses for three diffuse sources, which were calculated from measured concentrations and dose coefficients. Site specific meteorological data, stack flow data, and emissions estimates based on radionuclide usage inventory data or continuous stack monitoring data were the specific inputs to CAP88-PC for each modeled source. 
LLNL NESHAPs Report 2002

\section{SECTION I. Site Description}

LLNL was established in 1952 to conduct nuclear weapons research and development. The Laboratory's mission is dynamic and has been broadened over the years to meet new national needs. LLNL serves as a national resource in science and engineering; its activities focus on global security, energy, global ecology, biomedicine, economic competitiveness, and science and mathematics education. LLNL comprises two sites-the main laboratory site located in Livermore, California (Livermore site), and the Experimental Test Facility (Site 300) located near Tracy, California. Figure 1 shows the locations of the sites. The University of California operates LLNL for DOE.

\section{Livermore Site}

LLNL's Livermore site occupies an area of $3.3 \mathrm{~km}^{2}$ located about $60 \mathrm{~km}$ east of San Francisco, California, adjacent to the City of Livermore in the eastern part of Alameda County. In round numbers, 7 million people live within $80 \mathrm{~km}$ of the Livermore site; 76,700 of them live in the City of Livermore.

The Livermore site is located in the southeastern portion of the Livermore Valley, a topographical and structural depression oriented east-west within the Diablo Range of the California Coast Range Province. The Livermore Valley forms an irregularly shaped lowland area approximately $26 \mathrm{~km}$ long and an average of $11 \mathrm{~km}$ wide. The floor of the valley slopes from an elevation of approximately $200 \mathrm{~m}$ above sea level at the eastern end to approximately $90 \mathrm{~m}$ above sea level at the southwest corner.

The climate of the Livermore Valley is characterized by mild, rainy winters and warm, dry summers. The mean annual temperature is about $15^{\circ} \mathrm{C}$. Temperatures typically range from $-5^{\circ} \mathrm{C}$ during some pre-dawn hours in the winter, to $40^{\circ} \mathrm{C}$ on a few summer afternoons. The 2002 annual wind data for the Livermore site are displayed as a wind rose in Figure 2. Although winds are variable, the prevailing wind direction is from the southwest, especially during the summer. However, during the winter, the wind often blows from the northeast. Most precipitation occurs as rain between October and April with very little rainfall during the summer months. In 2002, the Livermore site received $271 \mathrm{~mm}$ of precipitation. 
LLNL NESHAPs Report 2002

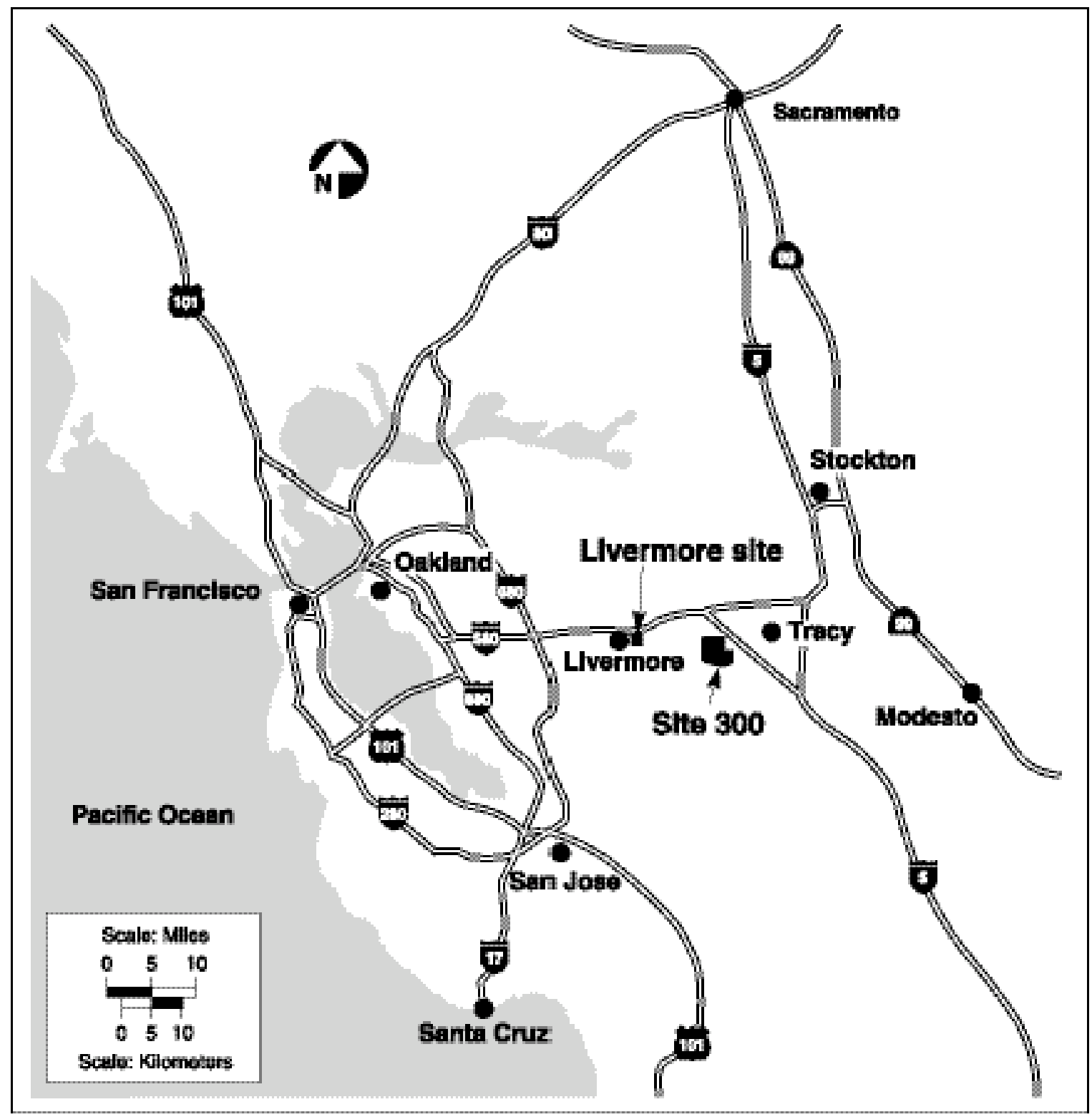

Figure 1. Locations of LLNL Livermore site and Site 300.

\section{Site 300}

Site 300, LLNL's Experimental Test Facility, is located $24 \mathrm{~km}$ east of the Livermore site in the Altamont Hills of the Diablo Range and occupies an area of $30.3 \mathrm{~km}^{2}$. A State of California vehicular-recreation area is located nearby, and wind-turbine generators line the surrounding hills. The remainder of the surrounding area is in agricultural use, primarily pasture land for cattle and sheep. The nearest residential 
LLNL NESHAPs Report 2002

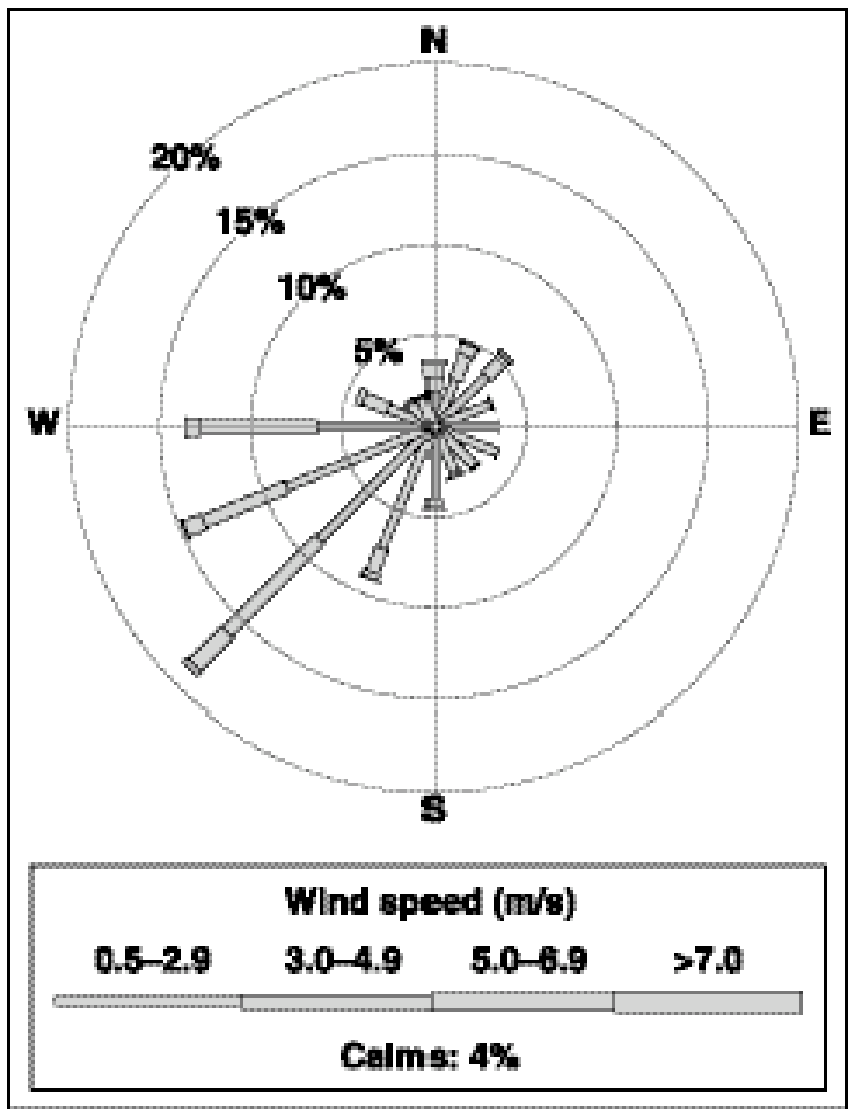

Figure 2. Wind rose showing the average annual wind speed, frequency of occurrence, and direction at the Livermore site, 2002.

area is the city of Tracy (population approximately 65,600), located $10 \mathrm{~km}$ to the northeast.

The topography of Site 300 is much more irregular than that of the Livermore site; it consists of a series of steep hills and ridges, which are oriented along a generally northwest/southeast trend, separated by intervening ravines. The elevation ranges from approximately $540 \mathrm{~m}$ in the northwestern portion of the site to $150 \mathrm{~m}$ at the southeast corner. The climate at Site 300 is similar to that of the Livermore site, with mild winters and dry summers. The complex topography of the site significantly influences local wind and temperature patterns, making the temperature range 
LLNL NESHAPs Report 2002

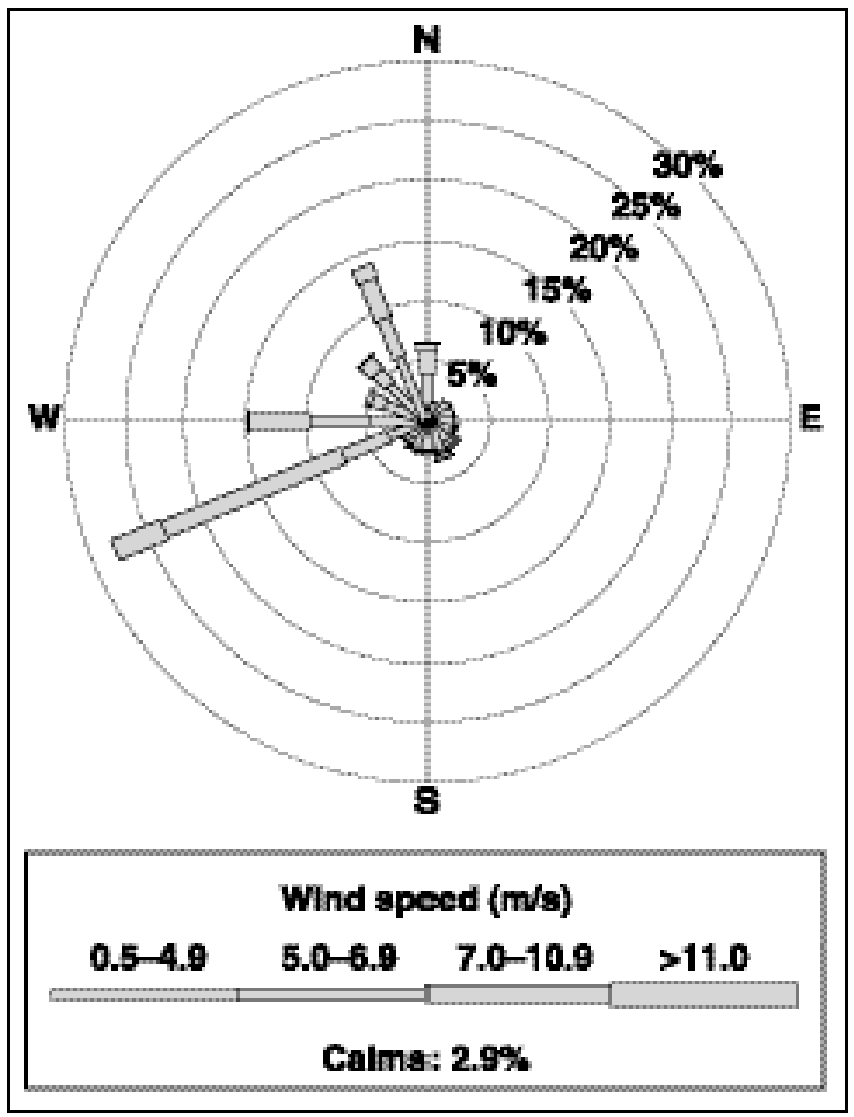

Figure 3. Wind rose showing the average annual wind speed, frequency of occurrence, and direction at Site 300, 2002.

somewhat more extreme than at the Livermore site. The 2002 annual wind data for Site 300 are displayed as a wind rose in Figure 3. Prevailing winds are from the westsouthwest. As is the case at the Livermore site, precipitation is highly seasonal, with most precipitation occurring between October and April. Site 300 received $220 \mathrm{~mm}$ of precipitation during 2002. The mean annual temperature is about $17^{\circ} \mathrm{C}$. 
LLNL NESHAPs Report 2002

\section{SECTION II. Air Emission Sources and Data}

\section{Sources}

Nearly a hundred different radioisotopes are used at LLNL for research purposes, including biomedical tracers, tritium, mixed fission products, transuranic isotopes, and others-see Table 1 for a list of the radionuclides and the "radionuclides" column in the Attachment 1 spreadsheet for a breakdown by facility. Radioisotope handling procedures and work enclosures are determined for each project, depending on the isotopes, the quantities being used, and the types of operations being performed. Work places include glove boxes, exhaust hoods, and laboratory bench tops. Exhaust paths to the atmosphere range from triple HEPA (High Efficiency Particulate Air) filtered ventilation systems, to roof vents and stacks lacking abatement devices, to direct dispersal of depleted uranium during explosives testing at Site 300, to a variety of diffuse area sources.

Table 1. Radionuclides used at LLNL during 2002.

\begin{tabular}{|c|c|c|c|c|c|}
\hline${ }^{3} \mathrm{H}$ & ${ }^{54} \mathrm{Mn}$ & ${ }^{99} \mathrm{Tc}$ & ${ }^{148} \mathrm{Gd}$ & ${ }^{229} \mathrm{Th}$ & ${ }^{240} \mathrm{Pu}$ \\
\hline${ }^{7} \mathrm{Be}$ & ${ }^{55} \mathrm{Fe}$ & ${ }^{103} \mathrm{Rh}$ & ${ }^{151} \mathrm{Pm}$ & ${ }^{230} \mathrm{Th}$ & ${ }^{241} \mathrm{Am}$ \\
\hline${ }^{10} \mathrm{Be}$ & ${ }^{57} \mathrm{Co}$ & ${ }^{106} \mathrm{Ru}$ & ${ }^{151} \mathrm{Sm}$ & ${ }^{231} \mathrm{~Pa}$ & ${ }^{241} \mathrm{Pu}$ \\
\hline${ }^{13} \mathrm{~N}$ & ${ }^{58} \mathrm{Co}$ & ${ }^{109} \mathrm{Cd}$ & ${ }^{152} \mathrm{Eu}$ & ${ }^{232} \mathrm{Th}$ & ${ }^{242} \mathrm{Cm}$ \\
\hline${ }^{14} \mathrm{C}$ & ${ }^{59} \mathrm{Ni}$ & $113 \mathrm{Sn}$ & ${ }^{154} \mathrm{Eu}$ & ${ }^{232} \mathrm{U}$ & ${ }^{242} \mathrm{Pu}$ \\
\hline $15 \mathrm{O}$ & ${ }^{60} \mathrm{Co}$ & ${ }^{125} \mathrm{I}$ & ${ }^{155} \mathrm{Eu}$ & ${ }^{233} U$ & $243 \mathrm{Am}$ \\
\hline${ }^{22} \mathrm{Na}$ & ${ }^{63} \mathrm{Ni}$ & $125 \mathrm{Sb}$ & ${ }^{172} \mathrm{Hf}$ & ${ }^{234} \mathrm{U}$ & ${ }^{244} \mathrm{Cm}$ \\
\hline${ }^{32} \mathrm{P}$ & ${ }^{75} \mathrm{Se}$ & ${ }^{131} \mathrm{I}$ & ${ }^{174} \mathrm{Lu}$ & ${ }^{235} \mathrm{U}$ & ${ }^{244} \mathrm{Pu}$ \\
\hline${ }^{33} \mathrm{P}$ & ${ }^{85} \mathrm{Sr}$ & ${ }^{133} \mathrm{~B} \mathrm{a}$ & ${ }^{195} \mathrm{Au}$ & ${ }^{236} \mathrm{Pu}$ & ${ }^{246} \mathrm{Cm}$ \\
\hline $35 s$ & $88 Y$ & ${ }^{134} \mathrm{Cs}$ & $195 \mathrm{mPt}$ & $236 U$ & ${ }^{248} \mathrm{Cm}$ \\
\hline${ }^{36} \mathrm{Cl}$ & ${ }^{90} \mathrm{Sr}$ & ${ }^{137} \mathrm{Cs}$ & ${ }^{207} \mathrm{~B} \mathrm{i}$ & ${ }^{237} \mathrm{~Np}$ & ${ }^{249} \mathrm{Cf}$ \\
\hline${ }^{40} \mathrm{~K}$ & $90 \mathrm{Y}$ & ${ }^{140} \mathrm{~B} \mathrm{a}$ & ${ }^{209} \mathrm{Po}$ & ${ }^{237} \mathrm{U}$ & ${ }^{250} \mathrm{Cf}$ \\
\hline${ }^{41} \mathrm{Ar}$ & ${ }^{94} \mathrm{Nb}$ & ${ }^{141} \mathrm{Ce}$ & $210 \mathrm{~Pb}$ & ${ }^{238} \mathrm{Pu}$ & ${ }^{252} \mathrm{Cf}$ \\
\hline${ }^{41} \mathrm{Ca}$ & $95 \mathrm{Nb}$ & ${ }^{144} \mathrm{Ce}$ & ${ }^{223} \mathrm{Ra}$ & ${ }^{238} \mathrm{U}$ & \\
\hline $46 \mathrm{Sc}$ & ${ }^{95} \mathrm{Zr}$ & ${ }^{147} \mathrm{Nd}$ & ${ }^{226} \mathrm{Ra}$ & ${ }^{239} \mathrm{~Np}$ & \\
\hline${ }^{51} \mathrm{Cr}$ & ${ }^{99} \mathrm{Mo}$ & ${ }^{147} \mathrm{Pm}$ & ${ }^{228} \mathrm{Th}$ & ${ }^{239} \mathrm{Pu}$ & \\
\hline
\end{tabular}

Sources of radioactive material emissions to air at LLNL are divided into two categories for purposes of evaluating NESHAPs compliance: point sources (including stacks, roof vents, and explosive experiments conducted on Site 300's firing tables) and diffuse area sources (including dedicated waste accumulation areas and other areas of known contamination). Several emission sources are treated as diffuse extended area sources, including Radioactive and Hazardous Waste Management's "Tank Farm" operations at Building 514 and waste storage at the Building 612 Yard, and other Livermore-site sources external to buildings. Detailed 
LLNL NESHAPs Report 2002

information is given in Attachment 1 for emissions from LLNL's radiological operations that took place during 2002.

\section{Air Monitoring}

In this section we describe continuous stack-effluent sampling systems at selected LLNL facilities and ambient air monitors in place at numerous locations on and off LLNL sites.

\section{Continuous Stack Air Effluent Monitoring}

Actual measurements of radioactivity in air and effluent flow are the basis for reported emissions from continuously monitored sources. In 2002, there were seven buildings (Buildings 175, 177, 235, 251, 331, 332, and 491) at the Livermore site and one building (Building 801A) at Site 300 that had radionuclide air effluent monitoring systems. These buildings are listed in Table 2, along with the number of samplers, the types of samplers, and the analytes of interest. Many samplers would operate from emergency power systems if normal power were lost.

Air samples for particulate emissions are extracted downstream of HEPA filters and prior to the discharge point to the atmosphere. Particles are collected on membrane filters. The sample filters are removed and analyzed for gross alpha and beta activity on a weekly or bi-weekly frequency depending on the facility. In most cases, simple filter aerosol collection systems are used. However, in some facilities, alpha continuous air monitors (CAMs) are used for sampling. In addition to collecting a sample of particles, the CAM units provide an alarm capability for the facility in the event of an unplanned release of alpha activity.

Detection of gross alpha and beta activity resulting from particles collected on the air filters is accomplished using gas flow proportional counters. Analysis is delayed for at least four days from the end of sample collection to allow for the decay of naturally occurring radon daughters. For verification of the operation of the counting system, calibration sources, as well as background samples, are intermixed with the sample filters for analysis. Analysis is performed by the Radiological Measurements Laboratory (RML) in LLNL's Hazards Control Department (HCD).

Each stack of the Tritium Facility (Building 331) is monitored for tritium release by both an alarmed continuous monitoring system and by molecular sieve continuous samplers. The alarmed monitors, which are Overhoff ion chambers, provide real time tritium concentration release levels (HT, HTO, or other gaseous forms). The sieve samplers discriminate between tritiated water (HTO) vapor and molecular tritium (HT); they provide the values used for environmental reporting and are exchanged weekly. Each sieve sampler (not alarmed) is in parallel with an alarmed monitor and consists of two molecular sieves. The first sieve collects tritiated water vapor; the second sieve contains a palladium-coated catalyst that converts molecular tritium to tritiated water, which is then collected. The molecular sieve samples are submitted to the Hazards Control Analytical Laboratory where they are put into a 
LLNL NESHAPs Report 2002

recovery system for the bake out of tritiated water vapor and subsequent condensation and collection of the water. The retrieved tritiated water is analyzed by RML using liquid scintillation counting techniques.

Environmental Protection Department (EPD) environmental analysts review data from air particulate sampling filters and molecular sieves.

Table 2. Air effluent sampling systems and locations.

\begin{tabular}{|c|c|c|c|c|}
\hline Building & Facility & Analytes & $\begin{array}{l}\text { Sample } \\
\text { type }\end{array}$ & $\begin{array}{l}\text { Number of } \\
\text { samplers }\end{array}$ \\
\hline 175 & MARS ${ }^{a}$ & Gross $\square, \square$ on particles & Filter & 6 \\
\hline 177 & Extractor Test ${ }^{a}$ & Gross $\square, \square$ on particles & Filter & 1 \\
\hline 235 & $\begin{array}{l}\text { Chemistry and } \\
\text { Materials Science }\end{array}$ & Gross $\square, \square$ on particles & Filter & 1 \\
\hline \multirow[t]{3}{*}{251} & Heavy Elements & & & \\
\hline & Unhardened area & Gross $\square, \square$ on particles & Filters & 24 \\
\hline & Hardened area & Gross $\square, \square$ on particles & Filters & 4 \\
\hline \multirow[t]{2}{*}{331} & Tritium & Tritium & $\begin{array}{l}\text { Ionization } \\
\text { Chamber } b\end{array}$ & 4 \\
\hline & & $\begin{array}{l}\text { Gaseous tritium/ } \\
\text { tritiated water vapor }\end{array}$ & Molecular sieves & 4 \\
\hline \multirow[t]{2}{*}{332} & Plutonium & Gross $\square, \square$ on particles & $\mathrm{CAM}^{\mathrm{b}}$ & 12 \\
\hline & & Gross $\square, \square$ on particles & Filters & 16 \\
\hline 491 & Isotope Separation ${ }^{a}$ & Gross $\square, \square$ on particles & Filters & 1 \\
\hline $801 \mathrm{~A}$ & $\begin{array}{l}\text { Contained Firing } \\
\text { Faciltiy }\end{array}$ & Gross $\square, \square$ on particles & Filters & 1 \\
\hline
\end{tabular}

Note: "CAM" denotes Eberline continuous air monitors.

a Operations discontinued, however, air effluent sampling systems at this building continue to operate as part of the maintenance and surveillance shutdown plan for the facilities. The Building 177 effluent sampling system was removed in Feb. 2002, after decontamination and decommissioning of the facility was completed.

b Alarmed systems.

Results of Stack Monitoring for Tritium: Operations in the Tritium Facility (Building 331) in 2002 released a total of $36 \mathrm{Ci}\left(1.3 \square 10^{12} \mathrm{~Bq}\right)$ of tritium. Of this, approximately $33 \mathrm{Ci}\left(1.2 \square 10^{12} \mathrm{~Bq}\right)$ were released as tritiated water $(\mathrm{HTO})$. The remaining $9.7 \%$ of the tritium released, $3.5 \mathrm{Ci}\left(1.3 \square 10^{11} \mathrm{~Bq}\right)$, was elemental tritium 
LLNL NESHAPs Report 2002

gas (HT). The highest single weekly stack emission from the facility was 3.8 Ci (1.4 $\square$ $10^{11} \mathrm{~Bq}$ ), of which more than $99 \%$ was HTO.

Building 331 tritium emissions, as measured by stack monitoring, remained considerably lower than levels that occurred during the 1980s. We anticipate that emissions over the next five years will exceed the 2000-2002 levels, as research and development work is performed for new programmatic efforts. However, engineered controls designed to contain and recapture tritium leakage should maintain relatively low emissions. Figure 4 illustrates the combined HTO and HT emissions from the facility since 1981.

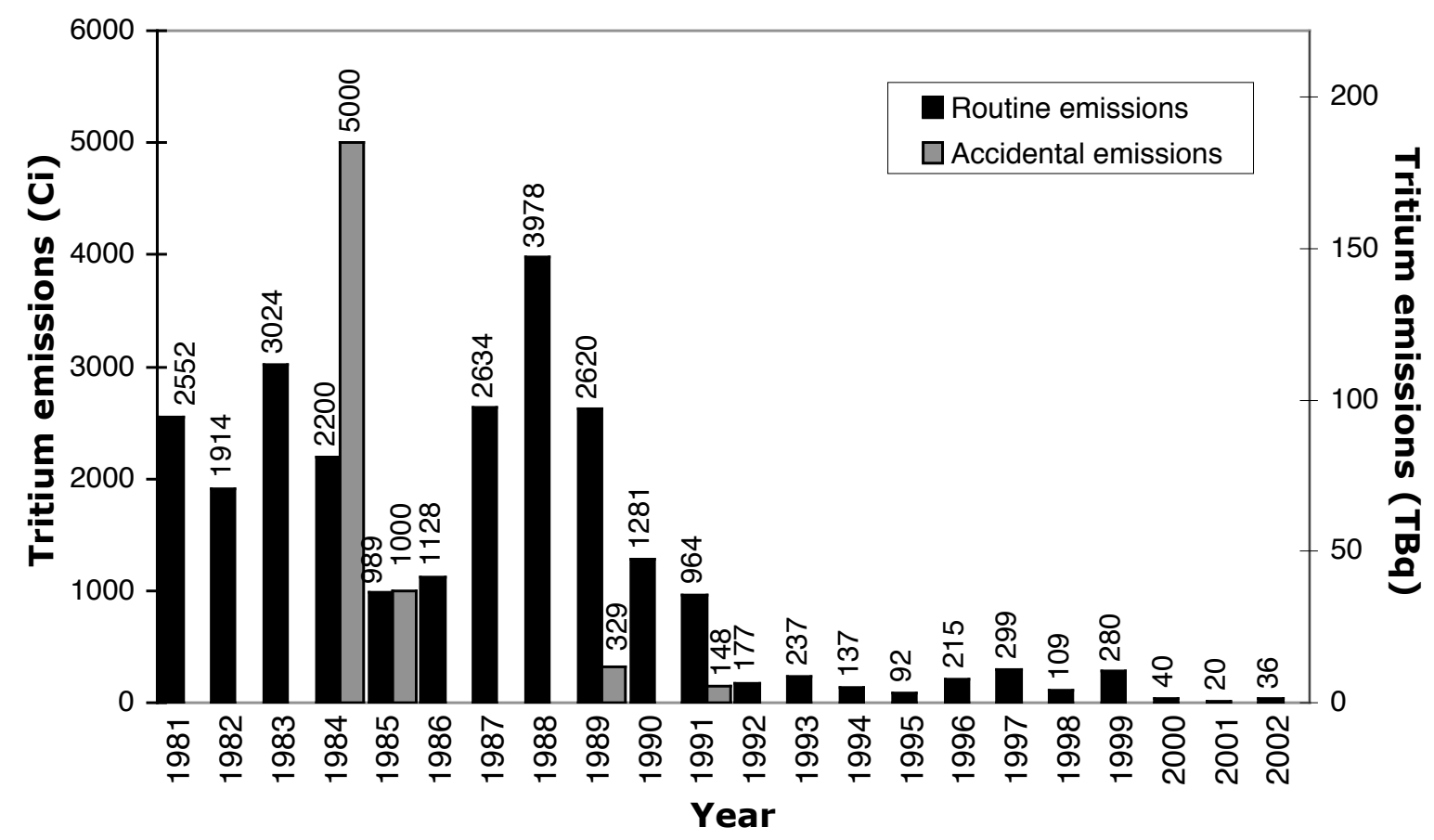

Figure 4. Combined HT and HTO emissions from the Tritium Facility, 1981-2002, distinguishing between chronic releases during normal operations (black bars) and acute accidental releases (gray bars). Accidental releases are predominantly HT gas.

Stack Monitoring for Gross Alpha and Gross Beta Radiation: For most discharge points at the other facilities where continuous stack sampling is performed, the results are below the minimum detectable concentration (MDC) of the analysis; sometimes as few as 1 to 4 samples (out of 25 to 50 per year) have concentrations greater than the MDC. Generally, these few samples having results above the MDC are only marginally above it. Use of zero values for this type of data can be justified based on knowledge of the facility, the use of tested, multiple stage, HEPA filters in all significant release pathways, and alpha spectroscopy based 
isotopic analyses of selected air sampling filters. These isotopic analyses demonstrate that detected activity on air sampling filters comes from naturally occurring radionuclides, such as radon daughters, e.g., polonium, on the air sampling filters. In addition, because of exhaust configurations at some facilities, the monitoring systems sometimes sample air from the ambient atmosphere along with the HEPA filtered air from facility operations, giving rise to background atmospheric radioactivity being collected. Because of these considerations, the emissions from such facility operations are reported as zero. As a result, there are no dose consequences, and doses reported for these operations are zero. Furthermore, even if the MDC values were used in calculations of the emission estimates for these facilities, which would be an extremely conservative approach, the total dose attributable to LLNL activities would not be significantly affected.

An effluent sampling system was installed in Building 801 at Site 300 in early 2002. Although all facility operations are HEPA filtered, this building has a large high bay room that exhausts to the stack without HEPA filtration. Consequently, some of the air sampled by the effluent sampling system is essentially outside, ambient air. In order to determine if any releases actually occurred from this facility, the sampling results must be compared to ambient air. In 2002, five samples out of 37 had concentrations greater than the MDC. The median concentration of the Building 801 stack detections, $1.3 \square 10^{-4} \mathrm{~Bq} / \mathrm{m}^{3}\left(3.6 \square 10^{-15} \mathrm{Ci} / \mathrm{m}^{3}\right)$, was lower than the median concentrations of the detections from two offsite sampling locations that are used to establish background levels of gross alpha and beta activity for direct comparison to results from the air effluent samplers. The median of all 37 of the five Building 801 samples, $3.0 \square 10^{-5} \mathrm{~Bq} / \mathrm{m}^{3}\left(8.0 \square 10^{-16} \mathrm{Ci} / \mathrm{m}^{3}\right)$, was approximately three times lower than the median of all of the offsite sampling location samples. Therefore, it is reasonable to conclude that Building 801 operations did not have radioactive emissions.

None of the facilities monitored for gross alpha and beta had emissions in 2002.

\section{Air Surveillance Monitoring for Radioactive Particles and Gases}

Surveillance air monitoring for tritium and radioactive particles has been in place since the 1970s. LLNL currently maintains seven continuously operating, high volume, air particulate samplers on the Livermore site, nine in the Livermore Valley, eight at Site 300, and one in Tracy. LLNL also maintains twelve continuously operating tritiated water vapor samplers on the Livermore site, six samplers in the Livermore Valley and one at Site 300. The samplers are positioned to ensure reasonable probability that any significant airborne concentration of particulate or tritiated water vapor effluents resulting from LLNL operations will be detected. Many of the surveillance air monitors are placed near diffuse emission sources, such as those near Buildings 292, 331, 514, and 612, as well as in and around the Southeast Quadrant of the Livermore site. As such, their results can be used to estimate and / or confirm the emissions from the associated diffuse sources. Also included is 
LLNL NESHAPs Report 2002

an air particulate monitor positioned at the location of the hypothetical maximallyexposed member of the public (defined in Section III) for the Livermore site. Data from air surveillance monitors provide a valuable test of predictions based on air dispersion modeling, and can help characterize unplanned releases of radioactive material.

The data from the surveillance air monitoring network provide continuous measurements of the concentrations of radionuclides present in the air at the Livermore site, Site 300, and in the surrounding areas. Data from the network are presented in the LLNL Site Annual Environmental Report (SAER), which is available to the public in hardcopy form, on CD, and on the Internet. (See, e.g., Gallegos et al., Environmental Report 2001, Lawrence Livermore National Laboratory, Livermore, CA, UCRL-5002701, September 2002; http: / / www.llnl.gov / saer).

\section{Radionuclide Usage Inventory Update}

A "partial" accounting of LLNL's radiological emission sources was made in 2002 (as was done in 2001), in accordance with the allowance by EPA that a 100\% accounting need be made only every third year. A $100 \%$ accounting was made when reviewing and reporting on operations conducted in 2000.

The partial accounting focused on sources in four categories: (1) the group of sources that collectively (in a ranked list) accounted for at least $90 \%$ of the dose to the maximally-exposed public individual from both the Livermore site and Site 300 in the previous year's (2001) assessment; (2) all "new" sources, i.e., those that commenced emissions in 2002, or sources that showed significantly elevated releases over 2001 levels; (3) all monitored sources; and (4) all sources in the major LLNL waste stream dealt with by Radioactive and Hazardous Waste Management (RHWM) Division in the Environmental Protection Department (EPD) of LLNL.

Radionuclide usage inventory forms, with guidance for completing them, were sent to all assurance managers, facility managers, and project-responsible persons connected with activities meeting these criteria for our partial accounting. The forms were completed by experimenters, and certified by facility managers. In particular, radionuclide usage data for all Site 300 explosives experiments and all significant stack and diffuse sources at both sites were included in this update. 


\section{SECTION III. Dose Assessment Methods \& Concepts}

\section{Description of the Air Dispersion and Dose Model}

Most estimates of individual and collective radiological doses to the public from LLNL operations were obtained using the EPA-developed computer code CAP88PC. The four principal pathways-internal exposures from inhalation of air, ingestion of foodstuff and drinking water, external exposures through irradiation from contaminated ground, and immersion in contaminated air-are evaluated by CAP88-PC. The doses are expressed as whole-body effective dose equivalents (EDEs), in units of mrem $/ \mathrm{y}(1 \mathrm{mrem}=10 \mu \mathrm{Sv})$. Separate doses for Livermore site and Site 300 emissions are reported. An LLNL-modified version of CAP88-PC (designated CAP88-PC-T) that contains an improved tritium model NEWTRIT (not yet approved by EPA for use in regulatory compliance evaluations), was also used in the assessment of inhalation and ingestion doses from tritium, for purposes of comparison.

Three potential doses are emphasized: (1) The dose to the site-wide maximally exposed individual (SW-MEI), which combines the contributions of all emission points to dose at a publicly-accessible facility (e.g., a business, church, school, or residence), for comparison to the $10 \mathrm{mrem} / \mathrm{y}(100 \mu \mathrm{Sv} / \mathrm{y})$ standard; (2) the maximum dose to any member of the public (assumed to be at the LLNL fence line), in any direction, due to each unabated emission point on the site to determine the need for continuous monitoring; and (3) the collective dose to populations residing within $80 \mathrm{~km}$ of the two LLNL sites, summing the products of individual doses received and number of people receiving them.

\section{Summary of Model Input Parameters}

General Model Inputs: Attachment 1 details the key identifiers and input parameters for the CAP88-PC model runs. These include building number; stack ID; isotope(s); emission rate in curies per year $\left(1 \mathrm{Ci}=3.7 \mathrm{q} 10^{10} \mathrm{~Bq}\right)$; and stack parameters, including height, diameter, and emission velocity.

Meteorological Data: All model runs used actual 2002 Livermore-site and Site 300 meteorological data, collected from the meteorological towers for each site. At these towers, wind speed and direction are sampled every few seconds, temperature sampled every minute, and all are averaged into quarter-hour increments, time tagged, and computer recorded. The data are converted into a CAP88-PC input wind file using EPA guidelines.

Surrogate Radionuclides: CAP88-PC contains a library of 265 radionuclides; however, it does not contain all the radionuclides in use at LLNL. As a consequence, it was necessary in a few cases to use surrogate radionuclides to estimate EDEs. Attachment 2 shows the surrogate radionuclides used in CAP88-PC. The selection of a suitable surrogate is based upon several criteria, including metabolically similar 
LLNL NESHAPs Report 2002

behavior and similar modes of decay and decay energies of the radiation type of the isotope of interest. Once a surrogate is selected, the equivalent source term is adjusted by the product of the initial inventory of the isotope of interest and the ratio of the effective dose equivalent of the surrogate to that of the isotope of interest. In some cases, experimenters did not provide isotopic analyses of mixtures of radionuclides, and they identified the radionuclides used as "gross alpha," "gross beta," "gross gamma," or "mixed fission products" (MFP). In these cases, ${ }^{239} \mathrm{Pu}$ was used as the surrogate for gross alpha, ${ }^{137} \mathrm{Cs}$ was used as the surrogate for gross gamma, and ${ }^{90} \mathrm{Sr}$ was used as the surrogate for gross beta and mixed fission products to provide conservative dose estimates.

Population Inputs: Population distributions centered on the two LLNL sites were compiled from the LandScan Global Population 1998 Database developed by Dr. Jerome Dobson at Oak Ridge National Laboratory. The population data files (distribution of population with distance and direction) used in the 2002 modeling effort are the same as those described in the 2000 NESHAPs annual report ( $L L N L$ NESHAPs 2000 Annual Report, Gallegos et al., June 2001).

Land Use and Agricultural Inputs: Options for model inputs regarding agricultural characteristics and land use are established by the EPA, and the particular designation selected can strongly influence the ingestion dose received by the population being evaluated. The "user entered" option was again selected for the CAP88-PC modeling effort for 2002. The values entered corresponded to the "local agriculture" option (everything is home produced), with one exception-all milk consumed was assumed to be imported when assessing dose to individuals (as opposed to populations). An assumption that all milk comes from local cows would not be supported by the agricultural activities conducted in the area. For population dose assessments, all food is considered to be locally grown, i.e., grown within an 80 $\mathrm{km}$ radius about the site; default densities of agricultural products in California are used.

Emission Source Terms: The source term for each emission point in the calculations was determined by one of two methods: For continuously monitored sources, the sampling data (curies released per unit time) for each radionuclide were used directly. For unmonitored facilities, the radionuclide usage inventories, together with time factors and EPA-specified physical state factors, are used to estimate potential emissions to air from a source. Time factors are used to adjust for the fact that a radionuclide may not always be in the same facility all year or may be encapsulated or enclosed for a substantial part of the year. Time factors are chosen to allow a more reasonable estimate of the amount of radioactive material released into the atmosphere. The EPA-specified factors for potential release to air of materials in different physical states (solid, liquid, powder, or gas) are those stated in 40 CFR Part 61, Appendix D. If the material was an unconfined gas, or any material heated above $100^{\circ} \mathrm{C}$ (with exceptions noted in Table 3), then the factor 1.0 was used; 
for liquids and powders, $1.0 \square 10^{-3}$ was used; and for solids, $1.0 \square 10^{-6}$ was used. The U.S. EPA has granted approval for LLNL to use alternative physical state factors for elemental uranium, uranium/niobium alloy, and elemental plutonium. Table 3 provides the approved temperatures for application of the physical state factor for each material.

These factors are allowed provided that the material is not intentionally dispersed to the environment and that the processes do not alter its chemical form. The physicalstate-dependent release fraction and the time factor are used to adjust (by multiplication) the total annual usage inventory to yield the potential annual release to air. In addition, emission control abatement factors (40 CFR 61, Appendix D), when applicable, were applied. Each HEPA filter stage was given a 0.01 abatement factor. (However, abatement factors were not used to evaluate compliance with the 0.1 mrem $[1 \mu \mathrm{Sv}]$ standard that determines the need for continuous monitoring at a facility.) The use of actual stack effluent sampling data is much more direct, and presumably more accurate, than using assumptions based on usage inventory, time factors, release fractions, and emission control factors.

Table 3. List of materials exempted from the "treat as a gas above $100^{\circ} \mathrm{C}$ rule," and temperatures at which the various physical state factors apply.

\begin{tabular}{lcccc}
\hline Material & $\begin{array}{c}\text { Solid physical } \\
\text { state factor }\end{array}$ & $\begin{array}{c}\text { Liquid physical } \\
\text { state factor }\end{array}$ & $\begin{array}{c}\text { Gas Physical } \\
\text { state factor }\end{array}$ & $\begin{array}{c}\text { Year } \\
\text { Approved }\end{array}$ \\
\hline Elemental uranium & $<1100^{\circ} \mathrm{C}$ & Between $1100^{\circ} \mathrm{C}$ and $3000^{\circ} \mathrm{C}$ & $>3000^{\circ} \mathrm{C}$ & 1996 \\
Uranium/niobium alloy $<1000^{\circ} \mathrm{C}$ & Between $1100^{\circ} \mathrm{C}$ and $3000^{\circ} \mathrm{C}$ & $>3000^{\circ} \mathrm{C}$ & 2001 \\
Elemental plutonium & $<600^{\circ}$ & Between $600^{\circ} \mathrm{C}$ and $3000^{\circ} \mathrm{C}$ & $>3000^{\circ} \mathrm{C}$ & 2001 \\
\hline
\end{tabular}

Site-Wide Maximally Exposed Individual: For LLNL to comply with the NESHAPs regulations, the LLNL site-wide maximally exposed individual cannot receive an EDE greater than $10 \mathrm{mrem} / \mathrm{y}(100 \mu \mathrm{Sv} / \mathrm{y})$. The site-wide maximally exposed individual (SW-MEI) is defined as the hypothetical member of the public at a single residence, school, business, church, or other such facility, who receives the greatest LLNL induced EDE from the combination of all radionuclide source emissions, as determined by modeling.

At the Livermore site, the SW-MEI for 2002 was found, as usual, to be located at the UNCLE Credit Union, about $10 \mathrm{~m}$ outside the controlled eastern fence line of the site, but about $10 \mathrm{~m}$ within the perimeter of the site property, as shown in Figure 5. At Site 300, the 2002 SW-MEI was again, as in the previous two years, located at the boundary with the Carnegie State Vehicle Recreation Area, managed by the California Department of Parks and Recreation, approximately $3.2 \mathrm{~km}$ south southeast of the firing table at Building 851, as shown in Figure 6. 


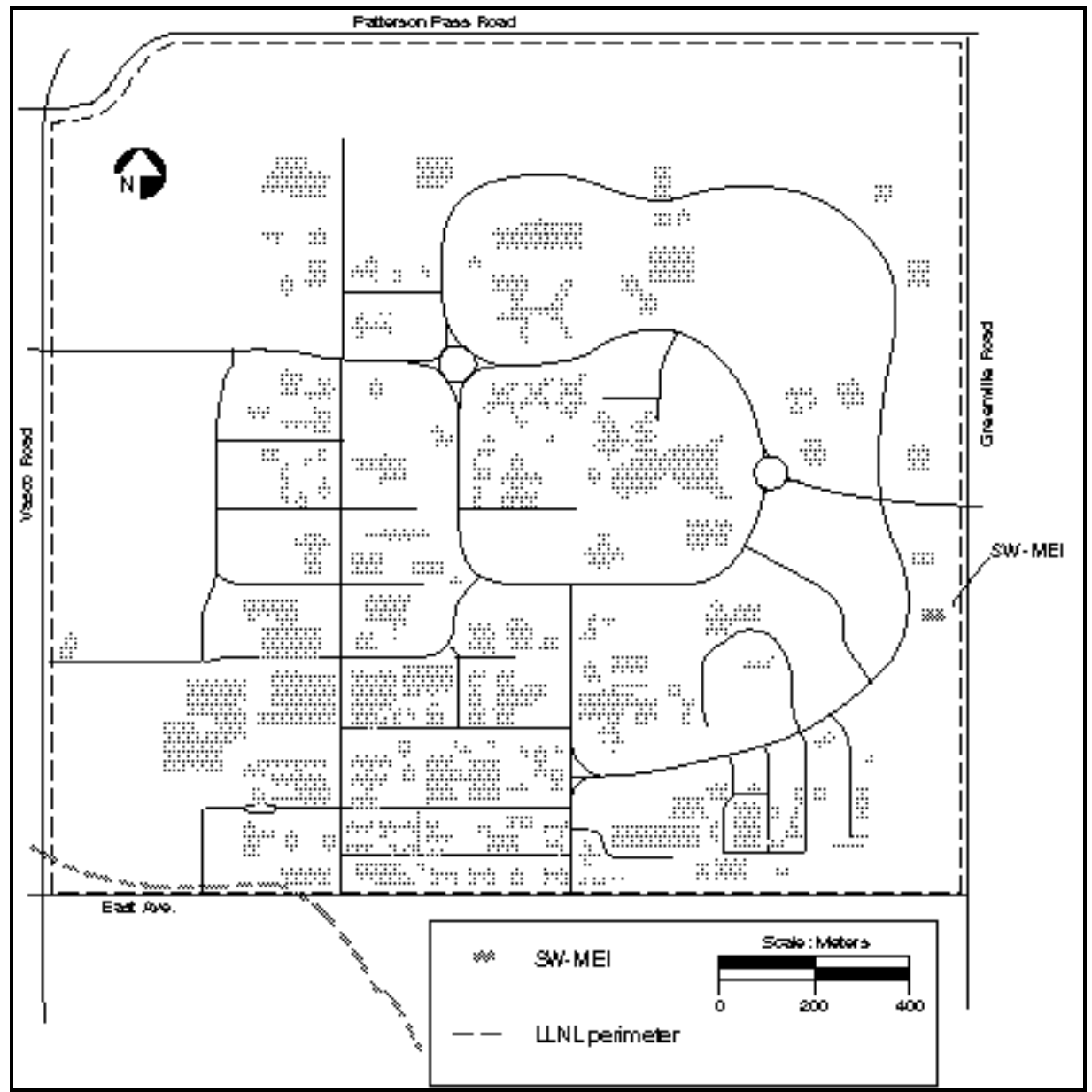

Figure 5. Location of Site-Wide Maximally Exposed Individual (SW-MEI) at the Livermore site, 2002.

In the Attachment 1 spreadsheet, the distance and direction to the respective SWMEI are shown for each facility at each site. Doses to the SW-MEIs were evaluated for each source and then totaled for site-specific evaluations against the $10 \mathrm{mrem} / \mathrm{y}$ $(100 \mu \mathrm{Sv})$ dose standard (see “Total Dose to Site-Wide Maximally Exposed Individuals" in Section IV).

Maximally Exposed Public Individual: To assess compliance with the EPA requirement for continuous monitoring of a release point (potential dose greater than $0.1 \mathrm{mrem} / \mathrm{y}[1.0 \mu \mathrm{Sv} / \mathrm{y}]$ ), emissions must be individually evaluated from each point source; the location of the maximally exposed public individual (MEI) is generally different for each emission point. The maximum dose at a location of unrestricted public access typically occurs at a point on the site perimeter. Therefore, it is often referred to as the maximum "fence line" dose, although the off-site maximum dose could occur some distance beyond the perimeter. (This could 
LLNL NESHAPs Report 2002

happen, e.g., when a stack is close to the perimeter; however, for all emission points at the Livermore site and Site 300, calculations show that ground level concentrations of radionuclides generally decline continuously beyond LLNL boundaries.) As stipulated by the regulations in 40 CFR Section 61.93 (b)(4)(ii), modeling for assessment of continuous monitoring requirements assumed unabated emissions (i.e., no credit was taken for emission abatement devices, such as filters). The Attachment 1 spreadsheet provides the dose to the MEI and the distance and direction to the LLNL fence line where the MEI is located.

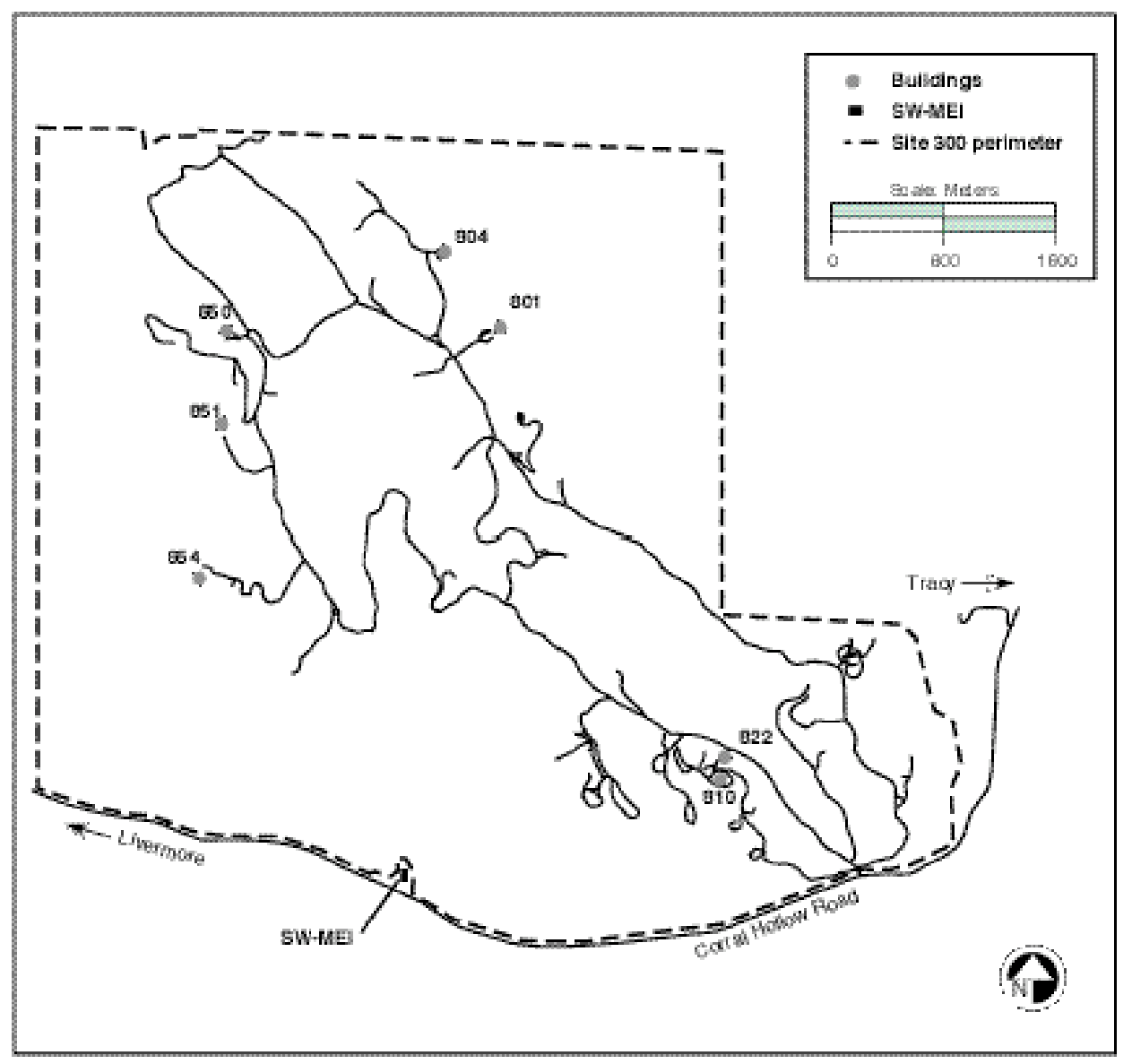

Figure 6. Location of Site-Wide Maximally Exposed Individual (SW-MEI) at Site 300, 2002.

\section{Special Modeling Challenges}

Among the sources at LLNL, explosives tests using depleted uranium at Site 300 and diffuse sources at both sites required special attention.

Site 300 Explosives Experiments: Some of the assemblies for Site 300 explosives experiments contain depleted uranium (DU) and possibly other 
LLNL NESHAPs Report 2002

radioactive materials. (The radioactive material does not contribute to the explosive energy, which is entirely chemical in origin.) The explosives assemblies are placed on an open-air firing table and detonated. Only limited data are available to characterize the initial state of the cloud of explosive decomposition products created by the detonation because properties of the cloud are not routinely measured in the experiments. Empirical scaling laws can be used, however, to define the size and height of the cloud using explosives inventories. When the assembly contains DU, the three uranium isotopes with atomic weights 238,235 , and 234 are assumed to occur in the cloud in the weight percentages 99.8, 0.2 , and $5 \square 10^{-4}$. Their masses are multiplied by their specific activities to determine the total activity for each isotope in the cloud. For simplicity, it is assumed that $100 \%$ of the uranium is aerosolized and dispersed as a gaseous cloud, and that the median particle size is the CAP88-PC default value of $1 \mu \mathrm{m}$. These assumptions result in a highly conservative off-site dose estimation. We believe the percentage of uranium dispersed is well below the assumed value of unity probably no greater than 0.2 - but considerable time and expense would be required to justify use of a lower value. Furthermore, CAP88-PC does not capture the short-duration, explosive nature of the release; rather it simulates each shot as a low level, steady state, stack-type emission occurring over one year. An alternative modeling methodology for treating these detonations, based on a "puff" code, was submitted to EPA for approval in 1992, but LLNL was directed to use the CAP88-PC code.

Diffuse Sources: Diffuse emissions generally arise from extended-area sources external to buildings. Such sources are difficult to quantify. At present there are no EPA-mandated methods for estimation or measurement of diffuse sources; dose calculations associated with this type of source are left to the discretion of the DOE contractor facility. Dose assessments for Livermore-site and Site 300 diffuse sources are variously derived based on radionuclide usage inventory data, environmental surveillance monitoring data, samples of contaminated materials, and other methods. The doses from principal diffuse sources in 2002 are described below in Section VIII.

\section{Modeling Documentation}

Dose assessment modeling runs were conducted for all sources (point and diffuse) meeting the criteria of the reduced accounting for 2002. The model used was EPA's CAP88-PC code (see Section III). Files were incorporated for meteorological data (wind, precipitation, and temperature) and population data representing both sites, along with the 2002 radionuclide usage inventory or stack effluent monitoring data. Annual dose is reported as whole-body EDE expressed in units of mrem (followed by $\mu \mathrm{Sv} ; 1 \mathrm{mrem}=10 \mu \mathrm{Sv}$ ). Copies of individual model runs, including input parameters and resultant calculated doses, are on file with the Terrestrial \& Atmospheric Monitoring \& Modeling Group (TAMM) of the Environmental Protection Department at LLNL. 


\section{SECTION IV. Results of 2002 Radiological Dose Assessment}

This section summarizes the doses to the most exposed public individuals from LLNL operations in 2002, shows the temporal trends and comparison to previous years, presents the potential doses to the populations residing within $80 \mathrm{~km}$ of either the Livermore site or Site 300, and summarizes LLNL's compliance with 40 CFR 61, Subpart H (61.93).

\section{Total Dose to Site-Wide Maximally Exposed Individuals}

The total dose to the Livermore site SW-MEI from operations in 2002 was $0.023 \mathrm{mrem}(0.23 \mu \mathrm{Sv})$. Of this, $0.010 \mathrm{mrem}(0.10 \mu \mathrm{Sv})$ or $43 \%$ was contributed by point sources, while diffuse emissions accounted for 0.013 mrem $(0.13 \mu \mathrm{Sv})$ or $57 \%$ of the total. The point source dose includes Tritium Facility HT emissions modeled as HTO, as directed by EPA Region IX. The SW-MEI dose calculated using CAP88-PCT with its NEWTRIT model (see "Modeling Dose from Tritium" in Section VII), rather than the default CAP88-PC code, reduced the tritium component of the Livermore site dose from $0.020 \mathrm{mrem}(0.20 \mu \mathrm{Sv})$ to $0.015 \mathrm{mrem}(0.15 \mu \mathrm{Sv})$.

The total dose to the Site 300 SW-MEI from operations in 2002 was 0.021 mrem $(0.21 \mu \mathrm{Sv})$. Point source emissions from firing table explosives experiments accounted for $0.018 \mathrm{mrem}(0.18 \mu \mathrm{Sv})$, or $85 \%$, of this total, while $0.0033 \mathrm{mrem}(0.033 \mu \mathrm{Sv})$, or about $15 \%$, was contributed by diffuse sources.

Table 4 shows the facilities or sources that accounted for more than $90 \%$ of the doses to the SW-MEI for the Livermore site and Site 300 in 2002. Although LLNL has nearly 200 sources with potential for releasing radioactive material to air according to NESHAPs prescriptions, most are very minor. Nearly the entire radiological dose to the public from LLNL operations comes from no more than a dozen sources. In 2002, a proposal was made to EPA for permission to use surveillance monitoring in place of inventorybased modeling to account for dose contributions from minor sources. This proposal was approved in April 2003 (see Attachment 3), and will be implemented for next year's NESHAPs annual report.

Table 5 compares 2002 doses with those of previous years. No diffuse emissions were reported at Site 300 for years before 1993, so comparison of total Site 300 dose can only be made for 1993 and later. In addition, diffuse source doses were not reported separately from the total dose for the Livermore site for 1990 and 1991.

\section{Doses from Unplanned Releases}

There were no unplanned atmospheric releases of radionuclides at the Livermore site or Site 300 in 2002. 
Table 4. List of facilities or sources whose emissions accounted for more than $90 \%$ of the SW-MEI doses for the Livermore site and Site 300 in 2002.

\begin{tabular}{|c|c|c|}
\hline Facility (source category) & $\begin{array}{c}\text { CAP88-PC } \\
\text { Dose in } \\
\text { mrem/y }\end{array}$ & $\begin{array}{c}\text { CAP88-PC } \\
\text { Percentage } \\
\text { contribution to total } \\
\text { dose }\end{array}$ \\
\hline \multicolumn{3}{|l|}{ Livermore site } \\
\hline Building 612 Yard (diffuse source) & $0.011^{*}$ & $48 \%$ \\
\hline Building 331 stacks (point source) & $0.0081^{*}$ & $35 \%$ \\
\hline Building 514 Evaporator (point source) & 0.0012 & $5.2 \%$ \\
\hline Building 612, R102 (point source) & 0.0011 & $4.8 \%$ \\
\hline Building 331 Outside (diffuse source) & $0.00087^{*}$ & $3.8 \%$ \\
\hline \multicolumn{3}{|l|}{ Site 300} \\
\hline Building 851 Firing Table (point source) & 0.018 & $85 \%$ \\
\hline Soil resuspension (diffuse source) & 0.0033 & $15 \%$ \\
\hline
\end{tabular}

\section{Population Doses}

Population doses, or collective EDEs, for both LLNL sites were calculated out to a distance of $80 \mathrm{~km}$ in all directions from the site centers using CAP88-PC. As noted earlier, CAP88-PC evaluates the four principal exposure pathways: ingestion through food and water consumption, inhalation, air immersion, and irradiation by contaminated ground surface.

Population centers affected by LLNL emissions include the relatively nearby communities of Livermore and Tracy, the more distant metropolitan areas of Oakland, San Francisco, and San Jose, and the San Joaquin Valley communities of Modesto and Stockton. Within the $80 \mathrm{~km}$ outer distance specified by DOE, there are 6.9 million residents included for the Livermore site population dose determination, and 6.0 million for Site 300. Population data files (distribution of population with distance and direction) used for the present report were the same as in the previous two years; see Tables 7 and 8 in LLNL NESHAPS 2000 Annual Report (Gallegos et al. 2001).

The CAP88-PC result for potential population dose attributed to 2002 Livermore-site operations was 0.50 person-rem (0.0050 person-Sv); the corresponding collective EDE from Site 300 operations was 2.5 person-rem ( 0.025 person-Sv). These values are both quite small and within the normal range of variation seen from year to year. By way of comparison, the population dose in the United States from exposure to the average level of natural background radioactivity is $1.9 \times 10^{6}$ person-rem $\left(1.9 \times 10^{4}\right.$ person-Sv). 
LLNL NESHAPs Report 2002

Table 5. Doses (in mrem) calculated for the Site-Wide Maximally Exposed Individual (SW-MEI) for the Livermore site and Site 300, 1990 to 2002.

\begin{tabular}{cccc}
\hline Year & Total Dose & Point Source Dose & Diffuse Source Dose \\
\hline Livermore site & & & \\
2002 & $0.023^{\mathrm{a}}$ & $0.010^{\mathrm{a}}$ & 0.013 \\
2001 & $0.017^{\mathrm{a}}$ & $0.0057^{\mathrm{a}}$ & 0.011 \\
2000 & $0.038^{\mathrm{a}}$ & $0.017^{\mathrm{a}}$ & 0.021 \\
1999 & $0.12^{\mathrm{a}}$ & $0.094^{\mathrm{a}}$ & 0.028 \\
1998 & $0.055^{\mathrm{a}}$ & $0.031^{\mathrm{a}}$ & 0.024 \\
1997 & 0.097 & 0.078 & 0.019 \\
1996 & 0.093 & 0.048 & 0.045 \\
1995 & 0.041 & 0.019 & 0.022 \\
1994 & 0.065 & 0.042 & 0.023 \\
1993 & 0.066 & 0.040 & 0.026 \\
1992 & 0.079 & 0.069 & 0.010 \\
1991 & 0.234 & $-\mathrm{b}$ & $-\mathrm{b}$ \\
1990 & 0.240 & $-\mathrm{b}$ & $-\mathrm{b}$ \\
Site 300 & & & \\
2002 & & 0.018 & 0.0033 \\
2001 & 0.021 & 0.050 & 0.0037 \\
2000 & 0.054 & 0.015 & 0.0037 \\
1999 & 0.019 & 0.034 & 0.0012 \\
1998 & 0.035 & 0.019 & 0.005 \\
1997 & 0.024 & 0.011 & 0.0088 \\
1996 & 0.020 & 0.033 & 0.00045 \\
1995 & 0.033 & 0.020 & 0.003 \\
1994 & 0.023 & 0.049 & 0.032 \\
1993 & 0.081 & 0.011 & 0.026 \\
1992 & 0.037 & 0.021 & $-\mathrm{c}$ \\
1991 & 0.021 & 0.054 & $\mathrm{c}$ \\
1990 & 0.044 & 057 & \\
\hline & 0.057 & & \\
\hline
\end{tabular}

a The dose includes HT emissions modeled as HTO as directed by EPA Region IX. EPA Region IX acknowledges that such modeling results in an overestimation of the dose. This methodology is used for purposes of compliance.

b Diffuse source doses were not reported separately from the total dose for the Livermore site for 1990 and 1991.

c No diffuse emissions were evaluated at Site 300 for years before 1993.

\section{Compliance with 40 CFR 61 Subpart H (61.93)}

Calculations of effective dose equivalents for Livermore-site and Site 300 facilities having the potential to release radioactive material to the atmosphere were found to be well below the 10 mrem $(100 \mu \mathrm{Sv})$ NESHAPs dose standard for dose to the mostexposed individual members of the public. Tritium accounted for more than $87 \%$ of the Livermore-site calculated dose, while at Site 300 practically the entire calculated dose was due to the isotopes $238 \mathrm{U}, 235 \mathrm{U}$, and $234 \mathrm{U}$, in depleted uranium. 
LLNL NESHAPs Report 2002

In 2002, there were seven buildings (Buildings 175, 177, 235, 251, 331, 332, and 491) at the Livermore site and one (Building 801, the Contained Firing Facility) at Site 300 that had radionuclide air effluent monitoring systems. These buildings are listed in Table 2, along with the number of samplers, the types of samplers, and the analytes of interest.

LLNL remains committed to monitoring stack effluent air from its Tritium Facility (Building 331), Plutonium Facility (Building 332), Contained Firing Facility (Building 801), and the seismically hardened area of its Heavy Element Facility (Building 251). In addition, other facilities are continuously monitored, as necessary, based on evaluations of potential emissions without control devices, as in the case of Building 235 , or where classification or other issues prevent a usage-inventory-based evaluation. 
LLNL NESHAPs Report 2002

\section{SECTION V. Certification}

I certify under penalty of law that this document and all attachments were prepared under my direction or supervision in accordance with a system designed to assure that qualified personnel properly gather and evaluate the information submitted. Based on my inquiry of the person or persons who manage the system, or those persons directly responsible for gathering the information, the information submitted is, to the best of my knowledge and belief, true, accurate, and complete. I am aware that there are significant penalties for submitting false information, including the possibility of fine and imprisonment for knowing violations.

Name: $\quad$ Dennis K. Fisher

Associate Director

Safety and Environmental Protection

Lawrence Livermore National Laboratory

7000 East Avenue, L-668

Livermore, CA 94550

Signature:

Date:

Dennis K. Fisher

I certify under penalty of law that I have personally examined and am familiar with the information submitted herein, and based on my inquiry of those individuals immediately responsible for obtaining the information, I believe that the submitted information is true, accurate, and complete. I am aware that there are significant penalties for submitting false information, including the possibility of fine and imprisonment. See 18 U.S.C. 1001.

Name: $\quad$ Phillip Hill

Acting Deputy Manager

Safety and Environmental Programs

U.S. Department of Energy

7000 East Avenue, L-293

Livermore, CA 94550

Signature:

Date:

Phillip Hill 


\section{SECTION VI. Supplemental Information on NESHAPs Compliance and QA/QC Activities}

\section{Requirements Under New EPA Standard for Stack Sampling}

In September 2002 EPA amended 40 CFR 61 Subpart H (NESHAPs) to require use of a new standard, ANSI N13.1-1999, for stack sampling of radiological effluent from certain newly constructed or modified facilities. This action replaced the existing standard ANSI N13.1-1969, and imposed some conditions on stack monitoring systems of existing facilities that are "grandfathered in" under the old standard. An assessment performed by TAMM Group in EPD identified 10 stack sampling systems (nine at the Livermore site and one at Site 300) that must satisfy the new standard, as listed in the following table.

Table 6. Livermore site and Site 300 stack sampling systems that must satisfy the maintenance and inspection requirements in the ANSI N13.1-1999 standard.

\begin{tabular}{|c|l|c|l|}
\hline Building & \multicolumn{1}{|c|}{ Exhaust } & Sampler ID & \multicolumn{1}{|c|}{ Operation } \\
\hline 251 & FGBE-1000 & PAM_46 & Hardened Area Glove Boxes \\
\hline 251 & FGBE-2000 & PAM_47 & Hardened Area Glove Boxes \\
\hline $695^{\text {(a) }}$ & FHE-1000, 2000, 3000 & PAM_1 & FHE, Waste Treatment Exhaust \\
\hline 332 & FGBE-1000 & SP_3 & Glove Box, Increment 1 \\
\hline 332 & FGBE-2000 & SP_4 & Glove Box, Increment 1 \\
\hline 332 & FGBE-3000 & SP_8 & Glove Box, Increment 1 \\
\hline 332 & FGBE-4000 & SP_9 & Glove Box, Increment 1 \\
\hline 332 & FGBE-7000, 8000 & SP_10 & Glove Box, Increment 3 \\
\hline 801 & FEFH-1, FE-2 & PAM_1 & Test Chamber, Facility Exhaust \\
\hline 235 & FHE-2001, 2002 & PAM_1 & $\begin{array}{l}\text { Hood and Glove Box Exhaust, } \\
\text { Room 1130 }\end{array}$ \\
\hline
\end{tabular}

a The stack for Building 695, LLNL's new Decontamination and Waste Treatment Facility, was not operational in 2002.

An implementation plan was prepared that addresses the inspection and calibration requirements of the new standard. The LLNL stack monitoring systems not cited in Table 6 are not required by NESHAPs regulations, but continue in operation as a best management practice. The new standard is described in a 1999 supplement to Health Physics Society Journal, entitled "Sampling and monitoring releases of airborne radioactive substances from the stacks and ducts of nuclear facilities" (report ANSI/HPS N13.1-1999). 


\section{Periodic Confirmatory Measurements}

Results of NESHAPs periodic confirmatory measurements serve to support or confirm two objectives: (1) that those operations not continuously monitored do not, in fact, need to be continuously monitored, and (2) that radionuclide usageinventory-based estimates of emissions and their corresponding doses are conservative. The particular sampling system chosen for study was randomly selected from a set of significant candidate sampling operations.

In 2002, periodic confirmatory sampling was conducted for a period of two weeks at Building 151, focused specifically on a dual stage HEPA filter system. This system ventilates a glovebox in which liquid samples of weapons grade Pu-238 are chemically purified. All measured concentrations were less than the minimum detectable concentrations for alpha and beta activity. Projecting these results to occur for an entire calendar year yields potential SW-MEI doses that would be seven orders of magnitude less than the EDE from all Livermore site operations for 2002. Because the dose calculated is estimated from a minimum detectable emission rather than an actual measured emission, it represents an upper-bound dose estimate, and is consistent with the dose based on the inventory approach and reported in Attachment 1.

\section{Proposal to EPA for Use of Surveillance Air Monitoring in Demonstrating NESHAPs Compliance for LLNL's Numerous Minor Sources}

In 2002 LLNL drafted a proposal to EPA Region IX, requesting permission to use surveillance air monitoring data in demonstrating NESHAPs compliance of radiological releases from the nearly 200 minor stack and diffuse sources at the Livermore site. This data would be used in place of inventory-based modeling, resulting in savings in time and money to both EPD and Laboratory Programs. This proposal and EPA's response in accepting it are reproduced in Attachment 3.

\section{NESHAPs Quality Assurance (QA) Program}

The LLNL NESHAPs quality assurance program is a multi-organizational effort that is described in the Lawrence Livermore National Laboratory Quality Assurance Project Plan for National Emission Standards for Hazardous Air Pollutants (NESHAPs), 40 CFR 61, Subpart H (QAPP-Hall, L.C. and A.H. Biermann, UCRL-ID-13914, 2000). The QAPP is structured in the manner prescribed for quality assurance programs that is outlined in Appendix B, Method 114 of 40 CFR 61. The QAPP describes the organization structure and functional responsibilities, objectives of the quality assurance program, administrative controls in place for handling sample collection systems, sample collection and effluent flow rate measurement systems, corrective actions, and reporting. 
The major components of this multi-organizational effort are the LLNL facilities / programs that have continuous monitoring systems, the Radiological Measurements Laboratory (RML) and the Analytical Laboratory (AL), both in the Hazards control Department (HCD), and the Environmental Protection Department (EPD). In addition to the QAPP, NESHAPs Agreement of Roles and Responsibilities (NARRs) documents are in place between EPD and the facilities and/or programs and HCD; these NARRs formalize responsibilities and obligations of the organizations regarding many tasks for the air effluent sample network. Tasks that are addressed in the NARRs include air sampler design and installation, procedures and their implementation, sampling, sample analysis and tracking, maintenance and repair of sampling systems, guidance on regulatory requirements, documentation of the sampling network, reporting, and the archival of records.

EPD is responsible for an annual assessment and demonstration of LLNL's compliance with NESHAPs. The Department operates under a Quality Assurance Management Plan and associated procedures and guidance documentation. The Terrestrial and Atmospheric Monitoring and Modeling Group (TAMM) of EPD is responsible for environmental monitoring; air dispersion and dose assessment modeling; assessment (in cooperation with Laboratory Program personnel) of usage and potential release of radioactive materials to air in operations throughout the Laboratory; and reporting to EPA and DOE to demonstrate the Laboratory's compliance with NESHAPs. Detailed records are kept of all measurements, computer model runs and other calculations, and selected model runs are validated. The TAMM group is informed of proposed new operations, and modified operations where significant changes in radiological usage inventories occur, by several mechanisms. These include reviews of National Environmental Policy Act (NEPA) documentation, Integration Worksheets, Occupational Safety Plans (describing facility-specific safety procedures and plans), and knowledge derived from participation on EPD's Environmental Support Teams. All NESHAPs evaluations and calculations, along with supporting information, are archived for at least the period of time specified in 40 CFR 61 Subpart H.

\section{Quality Control (QC) for 2002 Radiological Usage Inventory and Modeling}

Of the four-dozen sources for which modeling runs were performed in the reduced accounting for 2002, approximately $15 \%$ were selected for validation, which entails confirmation of both the source emission data and dose modeling calculations. Two sources (one from each of the two LLNL sites) were selected because they represented the most significant contributions to 2002 potential dose to the public; five additional sources were selected as the most important radiological activities in Radioactive and Hazardous Waste Management (RHWM) Division (from a public dose standpoint); and one significant diffuse source was selected. Specifically, the sources chosen for quality control review were the following: the Tritium Facility's 
LLNL NESHAPs Report 2002

two 30-m stacks; one explosives experiment conducted at Site 300's Firing Table 851; five sources reported by RHWM; and the Building 612 Yard waste tritium storage area.

More broadly, the quality and accuracy of our accounting and inventory processes were checked in several ways. In the accounting of new sources, more than 200 NEPA or related (primarily Integration Work Sheets and Occupational Safety Plans) documents were examined as they arose over the course of the year and reexamined collectively at year's end to identify all new 2002 projects having potential to release radioactive material to air. Additionally, all Radioactive Materials Management Areas new to 2002 were inventoried. The data characterizing the principal source at each site (principal in terms of producing the greatest potential dose to the public) were double-checked for accuracy. Finally, each radiological inventory form returned by the programs was scrutinized for consistency and evident errors as it was compiled and entered into the spreadsheet, Attachment 1. Based on these QC efforts, we believe that the data presented in Attachment 1 meets EPD's quality assurance objectives. 
LLNL NESHAPs Report 2002

\section{SECTION VII: Supplementary Information on Radiological Dose Assessment for 2002}

\section{Livermore-Site Principal Diffuse Sources}

The dose evaluations for diffuse sources at the Livermore site in 2002 required several different modeling approaches. Building 331 Outside Yard and Building 612 Yard emissions estimates were based on facility personnel knowledge and environmental surveillance data. Building 514 Tank Farm emissions estimates were derived from radiological usage inventory data. The dose in each of these cases was calculated using CAP88-PC. Air surveillance monitoring data for plutonium from a monitor located at the SW-MEI was used to evaluate the dose from plutonium contamination in the Southeast Quadrant.

\section{Building 331 Outside Yard}

As the Tritium Facility (Building 331) conducts operations, tritium-contaminated equipment and material slated for disposal is removed from the building, packaged in a waste accumulation and storage area, removed from the building to an outside storage container, and sent to Radioactive and Hazardous Waste Management Division (RHWM) facilities. During 2002, outgassing from such waste released an estimated 1.0 $\mathrm{Ci}\left(3.7 \mathrm{Q} 10^{10} \mathrm{~Bq}\right)$ of tritium to the atmosphere outside Building 331 . This amount was derived from process and facility knowledge and environmental surveillance measurements. This release was modeled in CAP88-PC as a $1 \mathrm{~m}^{2}$ area source, leading to a calculated 2002 dose to the SW-MEI of $8.7 \square 10^{-4}$ mrem (8.7 $\square$ $\left.10^{-3} \mu \mathrm{Sv}\right) ;$ a dose 0.75 times this amount was calculated when the NEWTRIT model was implemented in CAP88-PC.

\section{Building 514 Tank Farm}

Another potential source of diffuse emissions of a variety of radionuclides was RHWM waste storage and treatment operations. Building 514 houses the RHWM "Tank Farm," consisting of six 7,170-liter tanks with ancillary equipment such as pumps, mixers, probes, and a bulking station. The tanks are used to store and treat liquid and solid radioactive and / or mixed wastes. Treatment is performed on a batch basis. Chemicals and waste are added to the tanks to achieve the desired treatment objectives. A 2002 radionuclide usage inventory was conducted for the facility to determine the diffuse source term (Attachment 1). CAP88-PC modeling gave a 2002 SW-MEI dose for the Tank Farm to be $4.1 \square 10^{-4}$ mrem $\left(4.1 \square 10^{-3} \mu \mathrm{Sv}\right)$.

\section{Building 612 Yard}

The Building 612 Yard is a potential source of diffuse emissions of tritium. This area is dedicated to hazardous waste, radioactive waste, and mixed waste management activities. The yard consists of several areas where waste containers are stacked outdoors. Several of these containers outgas tritium. A surveillance air monitor designated B624 has been placed in the Building 612 Yard to provide continuous 
measurements of tritium in air near this source. The median annual concentration of tritium in air for 2002 in this area was $49 \mathrm{pCi} / \mathrm{m}^{3}\left(1.9 \mathrm{~Bq} / \mathrm{m}^{3}\right)$. These data were used to calculate the total tritium emissions from the area, using a conservative approach that assumed the source to be $60 \mathrm{~m}$ south-southwest of the air sampler. With this assumption, a diffuse source emission of $2.3 \mathrm{Ci} / \mathrm{y}\left(7.4 \square 10^{10} \mathrm{~Bq} / \mathrm{y}\right)$ was required to produce the concentrations measured at the air sampler. This source term produced a CAP88-PC-calculated 2002 dose to the SW-MEI from the Building 612 Yard of $1.1 \square$ $10^{-2}$ mrem $\left(1.1 \square 10^{-1} \mu \mathrm{Sv}\right) ;$ a dose 0.75 times this amount was calculated when the NEWTRIT model was implemented.

\section{Southeast Quadrant}

The Southeast Quadrant of the Livermore site has elevated levels of plutonium in the surface soil (from historic waste management operations) and air (from resuspension). A high volume air particulate sampler is located adjacent to the UNCLE Credit Union (the location of the SW-MEI) to monitor the plutonium levels in this area. Monitoring data from this air sampler were used as a direct measurement of potential dose via the air pathway. The median annual concentration of $239+240 \mathrm{Pu}$ (the analytical technique used, namely alpha spectroscopy, does not distinguish between ${ }^{239} \mathrm{Pu}$ and ${ }^{240} \mathrm{Pu}$ ) in air was $1.83 \times 10^{-19} \mathrm{Ci} / \mathrm{m}^{3}\left(6.76 \times 10^{-9} \mathrm{~Bq} / \mathrm{m}^{3}\right)$. Using the dose conversion factor of $3.08 \mathrm{x}$ $10^{5} \mathrm{mrem} / \mu \mathrm{Ci}\left(8.32 \times 10^{-5} \mathrm{~Sv} / \mathrm{Bq}\right)$ from Federal Guidance Report No. 11, EPA-520/188-020, U.S. Environmental Protection Agency (1988) for ${ }^{239} \mathrm{Pu}$ and ${ }^{240} \mathrm{Pu}$, and the standard man breathing rates of $8400 \mathrm{~m}^{3} / \mathrm{y}$, the dose was determined to be $4.7 \times 10^{-4}$ mrem $\left(4.7 \times 10^{-3} \mu \mathrm{Sv}\right)$ for 2002.

\section{Site 300 Principal Diffuse Sources}

Diffuse sources at Site 300 involve primarily depleted uranium, and to a considerably lesser extent, tritium. During remediation efforts at Site 300, LLNL completed a contaminant screening to identify potential routes of migration from soil to air and other environmental media of these radionuclides and other contaminants (Final Site Wide Remedial Investigation Report; Webster-Scholten, Ed., 1994, Lawrence Livermore National Laboratory, Livermore, CA, UCRL-AR-108131). Uranium-238 and tritium were identified as contaminants of potential concern.

\section{Tritium Evaporation and Migration at Site 300}

Tritium gas and solids containing tritium $\left(\mathrm{Li}^{3} \mathrm{H}\right)$ were components of explosives assemblies tested on the firing tables during experiments in years past. Most of the gaseous tritium escaped to the atmosphere during the tests, but some of the solid $\mathrm{Li}^{3} \mathrm{H}$ remained as residue in the firing table gravel. Rainwater and dust-control rinse water percolated through the gravel, causing the tritium to migrate into the subsurface soil and, in some cases, eventually to the ground water. Tritium contaminated gravel was removed from the firing tables in 1988 and disposed in the Pit 7 landfill. Tritium in landfills, firing table soils, and ground water are potential sources of diffuse emissions of tritium to the atmosphere at Site 300. LLNL 
personnel maintain an air tritium sampler at a perimeter location at Site 300, and doses from diffuse tritium sources may be estimated based on the monitoring data for that sampling location. For the calendar year 2002, all measurements in ambient air at the Site 300 perimeter location were consistent with natural background measurements.

\section{Resuspension of Depleted Uranium in Soil at Site $\mathbf{3 0 0}$}

Like tritium, depleted uranium has been used as a component of explosives test assemblies. It remains as a residue in surface soils, especially near the firing tables. Because surface soil is subject to resuspension by the action of wind, rain, and other environmental disturbances, the collective effects of surface soil uranium residuals on off-site doses were evaluated.

A model was developed to distinguish between the contribution to measured uranium activities arising from naturally occurring uranium (NU) and that from depleted uranium (DU) contributed by LLNL operations. (A derivation of the model was presented in LLNL NESHAPs 1995 Annual Report, Gallegos et al., 1996.) We base our dose estimate for resuspended depleted uranium (DU) on the measured environmental surveillance monitoring total concentration in air of uranium-238, subtracting out the part contributed by $\mathrm{NU}$, from the following equation:

$$
\square=\frac{0.00726 \square 0.99274 \frac{M(C U \square 235)}{M(C U \square 238)}}{0.00526 \frac{M(C U \square 235)}{M(C U \square 238)}+0.00526}
$$

where $\mu$ is the fraction (by weight) of uranium contributed by operations, $\mathrm{CU}$ is composite uranium (both DU and NU), M(CU-235) the mass of U-235 in the composite (measured) uranium, and $\mathrm{M}(\mathrm{CU}-238)$ the mass of $\mathrm{U}-238$ in the composite (measured) uranium.

For 2002, all eight air-particulate monitors at Site 300 were used to determine the annual-average concentrations of isotopes U-238 and U-235. These site-average values gave an estimate of $3.3 \times 10^{-3} \mathrm{mrem}\left(3.3 \times 10^{-2} \mu \mathrm{Sv}\right)$ for the SW-MEI dose resulting from resuspension of DU in soil for 2002.

\section{Modeling Dose from Tritium}

To evaluate dose from tritium releases to air, we use the EPA-sanctioned CAP88-PC code. Its tritium model calculates dose from inhalation, skin absorption, and ingestion of tritium only in its tritiated water vapor form (HTO). Doses from HT or organically bound tritium (OBT) are not calculated. CAP88-PC's tritium model is based on the specific activity model, which assumes that the tritium-to-hydrogen ratio in body water is the same as in air moisture. Because the specific activity model 
LLNL NESHAPs Report 2002

is linked in CAP88-PC with relatively high dose coefficients for HTO, the model's dose predictions generally err on the high side.

Inhalation doses from unit concentration of HT in air are a factor of 15,000 times lower than those from inhalation and skin absorption of unit concentration of HTO in air (International Commission on Radiological Protection (ICRP), 1995, Age dependent doses to members of the public from intake of radionuclides, Part 4, Inhalation Dose Coefficients. Oxford: Pergamon Press; ICRP Publication 71; Ann. ICRP 25[3\&4]). Thus, doses from inhaled HT can safely be ignored unless the air concentration is extremely high. A release of HT cannot be ignored, however, because HT that reaches the ground is rapidly and efficiently converted to HTO by microorganisms in soil (McFarlane, Rogers, and Bradley, Environmental Science and Technology 12: 590-593,1978; Brown, Ogram, and Spencer, Health Physics 58:171-181, 1990) and to a lesser extent in vegetation (Sweet and Murphy, Environmental Science and Technology, 18:358-361, 1984).

Organically bound tritium (OBT) is formed by plants during photosynthesis and is incorporated by animals when ingested. Animals also metabolize some OBT from ingested or inhaled HTO. The ICRP dose coefficient for OBT is about 2.3 times higher than that of HTO, because the biological half-life of OBT in the body is longer than that of HTO, which is eliminated at the same rate as body water. Although doses predicted by CAP88-PC are generally high enough to account for dose from ingested OBT, nevertheless, a model that explicitly calculates dose from OBT is preferable.

A simple tritium model, NEWTRIT, has been developed that calculates ingestion dose from both HTO and OBT and accounts for conversion of HT to HTO in the environment following releases of HT (Peterson, S-R. and P.A. Davis, Health Physics 82(2):213-225, 2002). For calculating doses in this report, LLNL has used the NEWTRIT model in CAP88-PC, in addition to the default CAP88-PC code, to estimate doses from significant sources of tritium emissions; see, e.g., Table 4. A brief discussion of the NEWTRIT model was presented in Attachment 2 of the 2000 NESHAPs annual report (LLNL NESHAPs 2000 Annual Report, Gallegos et al. June 2001).

In October 2001, LLNL sent a letter to EPA Region IX requesting consideration of NEWTRIT as an alternative methodology for calculating doses from atmospheric releases of tritiated water vapor (HTO) and tritiated gas (HT), for use in demonstrating compliance with radionuclide NESHAPs (40 CFR 61 Subpart H). In late 2002, the EPA had NEWTRIT coded into GENII-NESHAPs, a version of GENII (Napier et al. 1988) that the EPA plans to approve as a regulatory model for evaluating radionuclide NESHAPs compliance. At this writing, GENII-NESHAPs is undergoing peer review. 
LLNL NESHAPs Report 2002

\section{Comparison of 2002 Modeling Results with Tritium Air Surveillance Monitoring Data}

A comparison was made between CAP88-PC-predicted concentrations of tritium in air and ambient air monitoring data for eleven tritiated water vapor samplers on the Livermore site (designated VIS, SALV, POOL, CAFE, MESQ, MET, COW, B331, B514, B624, and B292) and one off-site sampler (ZON7) that have been used for comparison since 1997. In addition, a new air tritium monitor (DWTF) has been added to the comparison. Monitor locations are shown in Figure 7.

Only concentrations from the three most significant sources of tritium releases to air at the Livermore site were included in the model-data comparison. The largest point source is the Tritium Facility (Building 331), where tritium is emitted from two 30-mhigh, continuously monitored stacks. Based on stack monitoring, a total of $32.9 \mathrm{Ci}$ $\left(1.22 \square 10^{12} \mathrm{~Bq}\right)$ of HTO was emitted from Building 331 stacks in 2002. (The 3.47 Ci [1.28 $\square 10^{11} \mathrm{~Bq}$ of $\mathrm{HT}$ emitted from the Tritium Facility stacks is not included in the comparison because the tritium air surveillance monitors register only HTO.) Generally one would expect the Tritium Facility stacks to make the largest contribution to concentrations of tritium at distant monitors (e.g., ZON7), because the emissions are cast high into the air and carried with the wind. Diffuse-source emissions are lower to the ground, primarily affecting those monitors in close proximity. The other two principal sources in our modeling/measurement comparison are of this type: open-air diffuse emission areas associated with the Building 612 Yard and the Tritium Facility (Building 331) outside yard waste accumulation and storage areas. Emissions from the Building 612 Yard source were estimated to be $2.3 \mathrm{Ci}\left(8.5 \square 10^{10} \mathrm{~Bq}\right)$, based on calibrating CAP88PC-predictions of tritium concentrations at the tritium monitor B624 closest to it. (Thus the B624 data do not provide a test of the modeling.) Emissions from the B331 outside yard source were estimated to be $1.0 \mathrm{Ci}\left(3.7 \square 10^{10} \mathrm{~Bq}\right)$ in 2002, based on facility knowledge and environmental monitoring data (primarily the B331 monitor near this yard). While these two diffuse sources contribute significantly to tritium concentrations in all of the monitors, all other potential sources of tritiated water vapor release, such as the radioactive and hazardous waste management operations in Building 514 and the Building 292 diffuse source, were too minor to influence the overall model-data comparison.

Annual average concentrations of HTO in air $\left(\mathrm{pCi} / \mathrm{m}^{3}\right)$ at the locations of the thirteen monitors were modeled for the three sources individually and collectively, and compared to the measured annual mean concentrations. The results, displayed in Table 7, show that by taking into account the leading sources releasing tritiated water vapor to air, fairly good agreement is obtained between model runs and data for all of the air tritium monitors. 
LLNL NESHAPs Report 2002

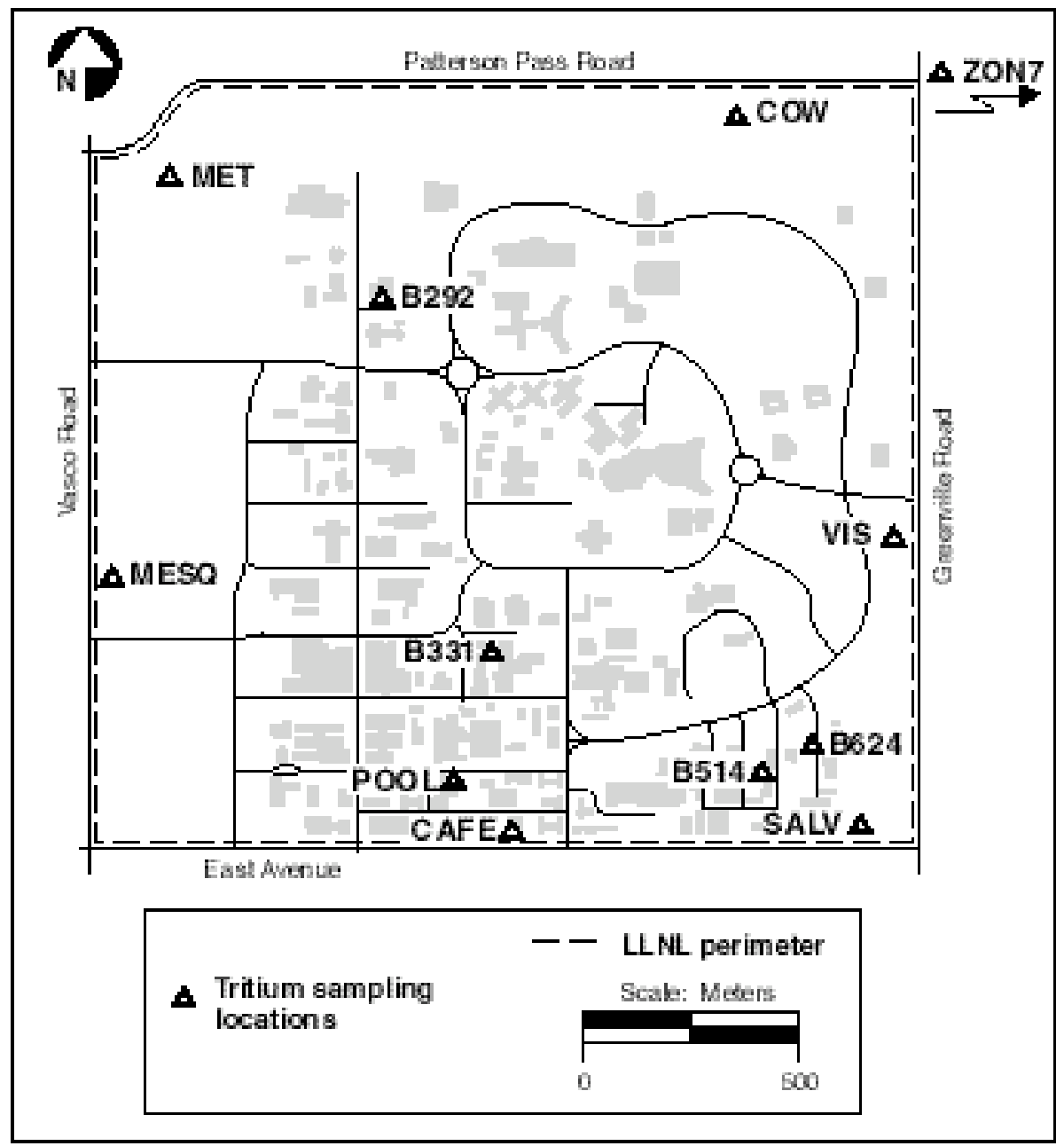

Figure 7. Tritiated water vapor surveillance sampling locations, Livermore site.

With the exception of the monitor B292 (which is probably under-predicted due to our neglect of a small contribution from a diffuse source nearby that only impacts that monitor), all predictions are equal to or greater than what was measured at the monitors. This means that in 2002, as in the past, CAP88-PC is over-estimating HTO in air from LLNL releases of HTO, particularly because CAP88-PC cannot account for the small amount of HTO resulting from conversion of HT. This consistent bias towards over-estimation since 1997 is probably caused by the relative importance of the diffuse sources for these years (Peterson, S-R. Testing CAP88-PC's Predicted Air Concentrations Against Historical Air Tritium Monitoring Data, 1986 - 2001, at Lawrence Livermore National Laboratory. In draft, 2003.). A comparison of AIRDOS-EPA predictions of air concentrations for various radionuclides ${ }^{234} \mathrm{U}$, ${ }^{238} \mathrm{U},{ }^{85} \mathrm{Kr}$, and ${ }^{3} \mathrm{H}$ ) with measurements at six different sites concluded that the $90 \%$ confidence interval for the accuracy of the CAP88-PC dispersion model ranged from a factor of 0.3 to 4.4, based on 51 samples ("Comparison of AIRDOS-EPA predictions of ground-level airborne radionuclide concentrations to measured values," Jack 
LLNL NESHAPs Report 2002

Faucett Associates, Bethesda, MD. 20814; JACKFAU-341/12-87; 1987). Similarly, the study (Peterson op. cit.) that compared CAP88-PC predictions with air tritium concentrations at 13 perimeter and off-site locations showed that ninety-six percent of all predictions fell within a factor of three of the observations, and slightly more than half of the predicted air concentrations were greater than the observed air concentrations.

Table 7. Comparison of measured and modeled annual mean concentrations of tritiated water vapor (HTO) in air at selected Livermore site locations, 2002.

\begin{tabular}{|c|c|c|c|c|c|c|}
\hline \multirow[t]{2}{*}{$\begin{array}{c}\text { Air monitor } \\
\text { (name) }\end{array}$} & \multirow[t]{2}{*}{$\begin{array}{c}\text { Mean } \\
\text { measured } \\
\text { concentration } \\
\left(\mathrm{pCi} / \mathrm{m}^{3}\right)\end{array}$} & \multirow[t]{2}{*}{$\begin{array}{c}\text { Modeled }^{\star} \\
\text { average } \\
\text { concentration } \\
\left(\mathrm{pCi} / \mathrm{m}^{3}\right)\end{array}$} & \multirow[t]{2}{*}{$\begin{array}{l}\text { Ratio of modeled- } \\
\text { to-measured } \\
\text { concentrations }\end{array}$} & \multicolumn{3}{|c|}{$\begin{array}{l}\text { Modeled concentration } \\
\text { of tritium in air contributed by } \\
\text { the indicated source }\left(\mathrm{pCi} / \mathrm{m}^{3}\right)\end{array}$} \\
\hline & & & & $\begin{array}{c}\text { B331 } \\
\text { Stacks }\end{array}$ & $\begin{array}{l}\text { B612 } \\
\text { Yard }\end{array}$ & $\begin{array}{c}\text { B331 } \\
\text { Outside }\end{array}$ \\
\hline B624 & 56.4 & 58 & 1.0 & 1.4 & 56 & 0.12 \\
\hline B331 & 10.0 & 14 & 1.4 & 0.051 & 1.4 & 13 \\
\hline POOL & 3.22 & 3.5 & 1.1 & 1.2 & 1.2 & 1.1 \\
\hline B514 & 3.15 & 8.4 & 2.7 & 0.56 & 7.7 & 0.11 \\
\hline B292 & 1.75 & 0.77 & 0.46 & 0.23 & 0.32 & 0.22 \\
\hline VIS & 1.72 & 2.6 & 1.5 & 1.2 & 1.3 & 0.14 \\
\hline CAFE & 1.67 & 2.2 & 1.3 & 0.68 & 1.2 & 0.35 \\
\hline DWTF & 1.45 & 1.5 & 1.0 & 1.2 & 0.24 & 0.10 \\
\hline $\mathrm{COW}^{\star \star}$ & 1.22 & 1.4 & 1.1 & 1.0 & 0.24 & 0.12 \\
\hline $\mathrm{SALV}^{\star \star}$ & 0.929 & 1.6 & 1.7 & 0.40 & 1.1 & 0.061 \\
\hline MESQ** & 0.755 & 0.97 & 1.3 & 0.20 & 0.35 & 0.42 \\
\hline ZON7 $7^{\star *}$ & 0.663 & 0.67 & 1.0 & 0.50 & 0.14 & 0.032 \\
\hline $\mathrm{MET}^{\star \star}$ & 0.458 & 0.49 & 1.1 & 0.15 & 0.19 & 0.15 \\
\hline$(\mathrm{CRED})^{\star \star \star}$ & & 3.5 & & 1.3 & 2.0 & 0.16 \\
\hline
\end{tabular}

*This result takes into account the three most significant tritium sources; it is the annualaverage concentration comprising the sum of the three contributions shown in the far right columns.

**At these locations, more than $25 \%$ of the samples were below detection limits. The annual mean includes negative concentrations for all except COW. MET has the lowest percentage of detections $(17 \%)$.

***The CRED location does not have a tritium surveillance air monitor, but it marks the location of the SW-MEI. 


\section{SECTION VIII. Supplemental Information on Other Compliance}

\section{Status of Compliance with Other Regulations Status of compliance with 40 CFR 61 Subpart Q - National Emission Standards for Radon Emissions from Department of Energy Facilities LLNL does not have storage and disposal facilities for radium containing materials that would be a significant source of radon.}

Status of compliance with 40 CFR 61 Subpart T - National Emission Standards for Radon Emissions from the Disposal of Uranium Mill Tailings LLNL does not have or store any uranium mill tailings.

\section{Information on Radon-220 and Radon-222 Emissions}

Radon emissions occur naturally by emanation from the earth. Radon-222 emissions that were reported in past NESHAPs annual reports from research experiments at the Livermore site did not occur in 2002. 


\section{ATTACHMENT 1. LLNL NESHAPs 2002 Annual Report Spreadsheet}

\section{Guidance for Interpreting the Data Spreadsheet}

A generalized description of each facility and its operations is provided on the spreadsheet. In addition, the following information is shown for each listed emission point or stack:

- $\quad$ Building and room number(s)

- $\quad$ Specific stack identification code(s)

- Generalized description of operations in the room(s) or area(s)

- Radionuclides utilized in the operation

- Annual radionuclide usage inventory with potential for release (by isotope, in curies)

- $\quad$ Physical state factors (by isotope)

- $\quad$ Stack parameters

- $\quad$ Emission control devices and emission control device abatement factors

- $\quad$ Estimated or measured annual emissions (by isotope)

- $\quad$ Distance and direction to the site-wide maximally exposed individual (SW-MEI)

- $\quad$ Calculated EDE to the SW-MEI

- $\quad$ Distance and direction to the maximally exposed individual for that specific source (MEI)

- $\quad$ Calculated EDE to the MEI (source term not adjusted for emission controls)

- $\quad$ Source category

\section{Radionuclides}

The radionuclides shown in the spreadsheet are those from specific emission points where air emissions were possible. If radionuclides were present, but encapsulated or sealed for the entire year, radionuclides, annual usage inventories, and emissions are not listed.

\section{Radionuclide Usage Inventories with Potential for Release}

The annual radionuclide usage inventories for point source locations are based on data from facility experimenters and managers. For Buildings 251 (hardened area) and 332 , classification issues regarding transuranic radionuclide usage inventories make use of the usage inventory/modeling approach impractical. However, all such affected emission points in these buildings are continuously monitored, and emissions are therefore directly determined. 
LLNL NESHAPs Report 2002

\section{Physical State Factors}

The physical state factors listed are EPA potential release fractions from 40 CFR 61, Appendix D, whereby emissions are estimated from radionuclide usage inventories depending on their physical states for use in dispersion/ dose assessment modeling. A physical state factor of $1.0 \square 10^{-6}$ is used for solids, $1.0 \square 10^{-3}$ is used for liquids and powders, and 1.0 is used for unconfined gases and substances heated above $100^{\circ} \mathrm{C}$. Regarding the latter, U.S. EPA has granted LLNL approved alternative emissions factors for elemental uranium, uranium/niobium alloy, and elemental plutonium. (See Table 3 in Section III.) These factors are allowed provided that the material is not intentionally dispersed to the environment and that the processes do not alter the chemical form of the material.

\section{Stack Parameters}

Engineering surveys conducted from 1990 through 1992 form the basis for the stack physical parameters shown, which were checked and validated by facility experimenters and managers for 1994 and 1995. Stack physical parameters for sources evaluated in 2002 were updated, as necessary, by experimenters and managers for those facilities.

\section{Emission Control Devices}

High Efficiency Particulate Air (HEPA) filters are used in many LLNL facilities to control particulate emissions. For some discharge points, scrubbers and electrostatic precipitators aid the control of emissions. The operational performance of all HEPA filtration systems is routinely tested. The required efficiency of a single stage HEPA filter is $99.97 \%$. Double staged filter systems are in place on some discharge points. Triple stage HEPA filters are used on glove box ventilation systems in the Building 332 Plutonium Facility and in the hardened portion of Building 251.

\section{Control Device Abatement Factors}

Similar to physical state factors, control device abatement factors, from Table 1 in 40

CFR 61, Appendix D, are those associated with the listed emission control devices, and are used to better estimate actual emissions for use in dispersion and dose models. By regulation, each HEPA filter stage is given a 0.01 factor (even though the required test efficiency that all LLNL HEPA filters must maintain would yield a factor of 0.0003).

\section{Estimated Annual Emissions}

For unmonitored and non-continuously monitored sources, estimated annual emissions for each radionuclide are based on the product of (1) usage inventory data, (2) time factors (discussed in "Emission Source Terms" in Section III, (3) EPA potential release fractions (physical state factors), and (4) applicable emission control device abatement factors. 
LLNL NESHAPs Report 2002

Actual emission measurements are the basis for reported emissions from continuously monitored facilities. LLNL facilities that had continuous monitoring systems in 2002 were Buildings 175, 177, 235, 251, 331, 332, and 491 at the Livermore site, and Building 801 at Site 300, as noted earlier. See the discussion below under "0.1 mrem/y Monitoring Requirement" regarding the use of emissions measurements for monitored sources.

\section{$10 \mathrm{mrem} / \mathrm{y}$ Site-Wide Dose Requirement}

For LLNL to comply with the NESHAPs regulations, the LLNL site-wide maximally exposed individual (SW-MEI; defined as the hypothetical member of the public at a single residence, school, business, or office who receives the greatest LLNL-induced EDE from the combination of all radionuclide source emissions) cannot receive an EDE greater than $10 \mathrm{mrem} / \mathrm{y}(100 \mu \mathrm{Sv} / \mathrm{y})$. (See Section III for a discussion of the SW-MEI.)

In the spreadsheet, the distance and direction to the respective SW-MEI are shown for each facility at each site. Doses to the site specific SW-MEIs were evaluated for each source and then totaled for site specific evaluations against the $10 \mathrm{mrem} / \mathrm{y}$ dose standard (see Section IV).

\section{$0.1 \mathrm{mrem} / \mathrm{y}$ Monitoring Requirement}

To assess compliance with the requirement for continuous monitoring (potential dose greater than $0.1 \mathrm{mrem} / \mathrm{y}[1.0 \mu \mathrm{Sv} / \mathrm{y}]$ to the maximally-exposed public individual or MEI, discussed earlier in Section III), emissions must be individually evaluated from each point source. The location of the MEI is generally different for each emission point. The maximum dose at a location of unrestricted public access typically occurs at a point on the site perimeter. Therefore, it is often referred to as the maximum "fence line" dose, although the off-site maximum dose could occur some distance beyond the perimeter. (This could happen, e.g., when the perimeter is close to a stack; however, for nearly all emission points at the Livermore site and Site 300, calculations show that ground level concentrations of radionuclides generally decline continuously beyond LLNL boundaries.) As stipulated by the regulations, modeling for assessment of continuous monitoring requirements assumed unabated emissions (i.e., no credit was taken for emission abatement devices, such as filters), but physical state factors and time factors were applied.

The unabated EDE cannot be calculated for HEPA-filtered facilities monitored for radioactive particles. Because the monitoring equipment is placed after HEPA filtration, there is no way to obtain an estimate for what the emissions might have been had there been no filtration. It is not reasonable to apply factors for the effects of the HEPA filters on the emission rate because most of what is measured on the HEPA filters is the result of the radioactive decay of radon, which is capable of penetrating the filter. The spreadsheet gives, for each inventoried point source, the 
LLNL NESHAPs Report 2002

dose to the MEI and the distance and direction to the LLNL fence line where the MEI is located. However, for HEPA-filtered monitored sources, no value is shown.

\section{Source Categories}

LLNL radionuclide air emission sources have been classified into seven source categories, indicated by the number in the next to last column of the spreadsheet: (1) Unmonitored or non-continuously monitored Livermore-site facilities that have had a radionuclide usage inventory update for 2002; (2) Unmonitored or noncontinuously monitored Livermore site facilities with a previous radionuclide usage inventory update (this category is not used in years with complete usage inventory updates, such as 2000); (3) Continuously monitored Livermore site facilities; (4) Site 300 explosives experiments; (5) Diffuse sources where emissions and subsequent doses were estimated using inventory processes; (6) Diffuse sources where emission and dose estimates were supported by environmental surveillance measurements; and (7) Sources whose emissions estimates and subsequent doses were estimated by confirmatory air sampling rather than continuous sampling. 
Attachment 1 - 2002 LLNL NESHAPs Annual Report Spreadsheet

\begin{tabular}{|c|c|c|c|c|c|c|c|c|c|c|c|c|c|c|c|c|c|c|c|}
\hline Building & Room/Area & Stack ID & Operation & Radionuclides & $\begin{array}{l}\text { Annual Inventory } \\
\text { with Potentia for }\end{array}$ & $\begin{array}{l}\text { Physical } \\
\text { State }\end{array}$ & 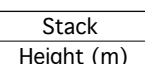 & $\begin{array}{l}\text { Stack } \\
\text { Diameter }\end{array}$ & $\begin{array}{l}\text { Stack } \\
\text { velocity }\end{array}$ & $\begin{array}{l}\text { Control } \\
\text { Devic(s) }\end{array}$ & $\begin{array}{l}\text { Control Device } \\
\text { Abatement } \\
\end{array}$ & $\begin{array}{l}\text { Estimated } \\
\text { Annual Einssions }\end{array}$ & $\frac{10 \mathrm{mrem} / \mathrm{s} \text { s }}{\text { Distance to }}$ & $\frac{\text { ite-Wide Do }}{\text { Direction }}$ & $\begin{array}{l}\text { se Requirement } \\
\text { EDE }\end{array}$ & $\begin{array}{c}\frac{0.1 \mathrm{mrem}}{\text { Distance }} \\
\end{array}$ & $\frac{y \text { Monitorinc }}{\text { Direction }}$ & $\begin{array}{l}\text { Requirement } \\
\text { Unabated }\end{array}$ & \begin{tabular}{|l|} 
Source \\
Category \\
\end{tabular} \\
\hline & & & & & $\begin{array}{l}\text { with Potential for } \\
\text { Release (Ci) }\end{array}$ & $\begin{array}{l}\text { State } \\
\text { Factor }\end{array}$ & Height (m) & $\begin{array}{c}\text { Diameter } \\
(\mathrm{m})\end{array}$ & $\frac{V^{\text {Velocity }}}{(m / s)}$ & Device(s) & $\begin{array}{l}\text { Abatement } \\
\text { Factor }\end{array}$ & $\begin{array}{l}\text { Annual Emissions } \\
\text { (Ci) }\end{array}$ & $\begin{array}{l}\frac{\text { Distance to }}{\text { SWMEI (m) }} \\
\end{array}$ & $\begin{array}{l}\text { Direction } \\
\text { to SWMEI }\end{array}$ & $\begin{array}{l}\text { EDE } \\
(\text { mrem) }\end{array}$ & $\begin{array}{l}\text { Distance } \\
\text { to MEI (m) }\end{array}$ & $\begin{array}{c}\text { Direction } \\
\text { to MEI }\end{array}$ & \begin{tabular}{|l} 
Unabated \\
EDE (mrem) \\
\end{tabular} & Category \\
\hline LIERMOF & SITE POINT SOU & CES & & & & & & & & & & & & & & & & & \\
\hline Bulling 1 | & complex is a lart. & e office/laboratory facility housin & g both Mechanical and Electrical Engi & eering Divisions. & & & & & & & & & & & & & & & 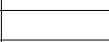 \\
\hline 131 & 1221 & FFE-02 & Storage and cleaning of & U-238 & $6.1 \mathrm{E}-06$ & $1.0 E-06$ & 12.2 & 0.15 & 7.8 & HEPA & 0.01 & $6.1 E-14$ & 1326 & E & $3.1 E-12$ & 567 & WNW & $1.4 E-09$ & 2 \\
\hline & & & assemblies & $\frac{U-235}{U U-234}$ & $\begin{array}{l}7.9 E-08 \\
5.77-07\end{array}$ & $\begin{array}{l}1.0 \mathrm{OE}-06 \\
1.0-06\end{array}$ & & & & & & $\begin{array}{l}7.9 E-16 \\
5.7 E-15 \\
5\end{array}$ & & & tis & 然 & (n) & 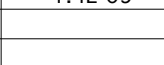 & $E$ \\
\hline 131 & 1248 & Room Air & Storage and display of & U-238 & $1.5 E-06$ & $1.0 E-06$ & NA & NA & $\mathrm{NA}$ & None & 1 & $1.5 E-12$ & 1326 & $E$ & $8.6 E-11$ & 524 & w & $1.4 E-09$ & 2 \\
\hline & & & post-test materials & $\begin{array}{l}-235 \\
U-234 \\
\end{array}$ & $\begin{array}{l}2.0 \mathrm{CO}-08 \\
1.4 \mathrm{E}-07 \\
\end{array}$ & $\begin{array}{l}1.0 E-06 \\
1.0 E-06 \\
\end{array}$ & & & & & & $\begin{array}{l}2.0 E-14 \\
1.4 E-13 \\
\end{array}$ & & & & & 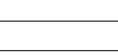 & & \\
\hline 131 & $1248 \mathrm{~A}$ & Room Air & 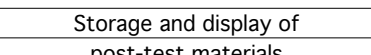 & U-238 & $\begin{array}{l}7.7 E-07 \\
0.050 .99\end{array}$ & $\begin{array}{l}1.0 \mathrm{OE}-06 \\
1.0-06\end{array}$ & NA & $\mathrm{NA}$ & $\mathrm{NA}$ & None & 1 & 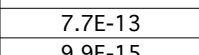 & 1326 & E & $4.3 E-11$ & 524 & w & $6.9 E-10$ & 2 \\
\hline & & & & $\mathrm{U}-234$ & $7.2 E-08$ & $1.0 E-06$ & & & & & & $7.2 E-14$ & & & & & & & \\
\hline & & & & & & & & & & & & & & & & & & & \\
\hline 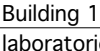 & $\begin{array}{l}\text { Provides office } \\
\text { in the Anatycical }\end{array}$ & 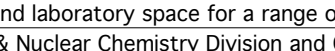 & 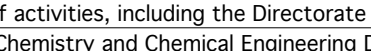 & $\begin{array}{l}\text { fffices for Chemist } \\
\text { visison; and NAA Dir }\end{array}$ & $\begin{array}{l}\text { and Materials Scien } \\
\text { torate Forensic Scie }\end{array}$ & & fices and labc & ies. & & & & & & & & & & & \\
\hline (1) & (2) & Euclearchemisty uvision and & nemistry ana Cnemical tngineeering $L$ & Viston; and INAI Uir & 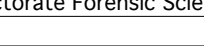 & 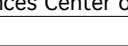 & 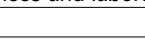 & & & & & & & & & & & & \\
\hline $132 \mathrm{~N}$ & 2671 & FHE-6000/7000 & Mass spectrometry analysis & $\begin{array}{l}\text { Pu-238 } \\
\text { Put } 239\end{array}$ & $\begin{array}{l}6.1 \mathrm{E}-07 \\
4.5 E-08\end{array}$ & 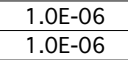 & 38.1 & 2.13 & 11.3 & Double HEPA & 0.0001 & $\begin{array}{l}6.1 E-17 \\
4.5-18\end{array}$ & 1504 & E & $2.86-15$ & 1918 & NE & $3.8 \mathrm{E}-11$ & 2 \\
\hline & & & & $\begin{array}{l}\text { Pu-240 } \\
\text { Puu-241 }\end{array}$ & $\begin{array}{l}\frac{1.1 \mathrm{E}-08}{1.1 \mathrm{E}-07} \\
\end{array}$ & $\begin{array}{l}\frac{1.0 \mathrm{E}-06}{1.06-06} \\
\end{array}$ & & & & & & 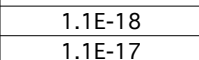 & & & & & & & 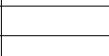 \\
\hline & & & & Pu-242 & $1.4 \mathrm{E}-12$ & $1.0 \mathrm{E}-06$ & & & & & & $1.46-22$ & & & & & & & \\
\hline & & 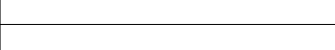 & & $\begin{array}{c}A m-241 \\
\mathrm{U}-234\end{array}$ & $\begin{array}{l}\frac{1.1 E-09}{6.1 E-12} \\
6\end{array}$ & 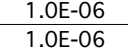 & & & & & & 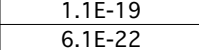 & & & & & & & \\
\hline $132 \mathrm{~N}$ & 2675 & FHE-6000/7000 & Preparation of aqueous & $\mathrm{U}-234$ & $2.6 E-18$ & $1.0 \mathrm{E}-03$ & 38.1 & 2.13 & 8.6 & None & 1 & $2.6 E-21$ & 1504 & E & $6.7 E-16$ & 481 & sw & $1.0 E-15$ & 2 \\
\hline & & & solutions for analysis & $\begin{array}{l}0-253 \\
-238 \\
\end{array}$ & $\begin{array}{l}3.3 E-16 \\
4.6-14\end{array}$ & $\begin{array}{l}1.0 \mathrm{U}-\mathrm{E}-\mathrm{S} \\
1.0 \mathrm{E}-03\end{array}$ & & & & & & $\begin{array}{l}3.3 E-19 \\
4.6 E-17\end{array}$ & & & & & & & \\
\hline & & FHE-6000/7000 & Analysis of aqueous solutions & U-234 & $1.3 \mathrm{E}-14$ & $1.0 E+00$ & 38.1 & 2.13 & 8.6 & HEPA & 0.01 & $1.3 E-16$ & 1504 & $E$ & $3.3 \mathrm{E}-11$ & 481 & SW & $5.2 \mathrm{E}-09$ & 2 \\
\hline & & & & $0-238$ & $2.3 E-10$ & $\frac{1.0 \mathrm{E}+00}{1.00}$ & & & & & & $2.3 E-12$ & & & & & & & \\
\hline $132 \mathrm{~N}$ & 2679 & FHE-6000/7000 & Preparation of aqueous & $\mathrm{U}-234$ & $3.7 E-17$ & $1.0 €+00$ & 38.1 & 2.13 & 8.6 & HEPA & 0.01 & $3.7 E-19$ & 1504 & $E$ & $1.3 E-12$ & 481 & Sw & $2.0 E-10$ & 2 \\
\hline & & & solutions for analysis & $\begin{array}{l}0-335 \\
-238\end{array}$ & $\frac{1.5 E-14}{7.5-12}$ & $\frac{1.0 E+00}{1.0+00}$ & & & & & & $\frac{1.5 E-1}{7.45-1}$ & & & & & & & \\
\hline & & & & Th-232 & $5.5 E-13$ & $1.0 \mathrm{E}+00$ & & & & & & $5.5 E-15$ & & & & & & & \\
\hline $132 \mathrm{~N}$ & 2685 & FHE-6000/7000 & Transfer and solvent extraction & Cs-137 & $8.8 E-09$ & $1.0 E-03$ & 38.1 & 2.13 & 8.6 & None & 1 & $9.0 E-12$ & 1504 & $\mathrm{E}$ & $3.8 \mathrm{E}-11$ & 481 & sw & $6.2 E-11$ & 2 \\
\hline & & & $\begin{array}{l}\text { of waste samples } \\
\text { for pCC annlysis }\end{array}$ & $\frac{C 0-60}{S S-90}$ & $\begin{array}{l}4.4 E-10 \\
4.8-599\end{array}$ & $\begin{array}{l}1.0 \mathrm{OE}-03 \\
10.03\end{array}$ & & & & & & $\begin{array}{l}4.55-13 \\
4.95-12\end{array}$ & & & & & & & \\
\hline & & & & Th-228 & $3.4 E-13$ & $1.0 \mathrm{E}-03$ & & & & & & $3.5 E-16$ & & & & & & & \\
\hline & & & & $\begin{array}{l}\text { Th-230 } \\
\text { The-232 }\end{array}$ & $\frac{1.0 E-12}{725-14}$ & $\begin{array}{l}1.0 \mathrm{OE}-03 \\
10.02\end{array}$ & & & & & & $\begin{array}{l}1.06-15 \\
7.0517-17\end{array}$ & & & & & & & \\
\hline & & & & Pu-238 & $\frac{7.2-14}{1.0 E-11}$ & 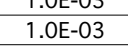 & & & & & & $\begin{array}{l}7.4 E-17 \\
1.1 E-14\end{array}$ & & & & & & & \\
\hline & & & & $\begin{array}{l}\text { Pu-239 } \\
\text { Put-240 }\end{array}$ & 4.4-4E-10 10 & $1.0 \mathrm{E}-03$ & & & & & & 4.5E-13 & & & & & & & \\
\hline & & & & $\begin{array}{l}\text { Put-240 } \\
\text { Pu-241 }\end{array}$ & $\begin{array}{l}2 . \mathrm{L}-10 \\
2.4 \mathrm{E}-10\end{array}$ & $\frac{1.0 \mathrm{C}-\mathrm{J}}{1.0 \mathrm{E}-03}$ & & & & & & $\begin{array}{l}2.8 E-13 \\
2.5 E-13 \\
\end{array}$ & & & & & & & \\
\hline & & & & Am-241 & $\begin{array}{l}2.4 E-11 \\
.050 \\
0.12\end{array}$ & $\begin{array}{l}1.0 \mathrm{OE}-03 \\
1.0-02\end{array}$ & & & & & & $\begin{array}{l}2.5 E-14 \\
70-15\end{array}$ & & & & & & & \\
\hline & & & & $\begin{array}{ll}-5.245 \\
-1-235\end{array}$ & $\begin{array}{l}0 \\
0.9-1 \\
3.9-13\end{array}$ & $\begin{array}{ll}1.00=03 \\
10=03\end{array}$ & & & & & & $\begin{array}{ll}4.0 E-16 \\
4.0 E-16\end{array}$ & & & & & & & \\
\hline & & & & u-238 & $1.2 E-12$ & $1.0 \mathrm{E}-03$ & & & & & & $1.2 E-15$ & & & & & & & \\
\hline $132 \mathrm{~N}$ & 2689 & FHE-6000/7000 & Differential Scanning Calorimetry & U-238 & $5.11-07$ & $1.0 \mathrm{E}-06$ & 38.1 & 2.13 & 11.2 & None & 1 & 5.1E-13 & 1504 & $\mathrm{E}$ & $8.3 E-12$ & 481 & sw & $1.3 E-11$ & 1 \\
\hline & & & Orcnemican mixtures & $0-234$ & 4. & 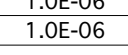 & & & & & & $\begin{array}{l}4.35-13 \\
4.7 E-14 \\
\end{array}$ & & & & & & & \\
\hline $132 \mathrm{~N}$ & 2694 & FHE-6000/7000 & Transfer and solvent extraction & Cs-137 & $\begin{array}{l}5.77-09 \\
7200\end{array}$ & $1.0 \mathrm{E}-03$ & 38.1 & 2.13 & 8.6 & None & 1 & $5.77-12$ & 1504 & $\mathrm{E}$ & $2.5 E-11$ & 481 & sw & $3.9 E-11$ & 2 \\
\hline & & & $\begin{array}{l}\text { of waste samples } \\
\text { for volatiles analysis }\end{array}$ & $\frac{00-60}{S r-90}$ & $\begin{array}{l}2.7 E-10 \\
3.0 E-09\end{array}$ & $\frac{1.0 \mathrm{O}-\mathrm{E}-3}{1.03}$ & & & & & & $3.0 \mathrm{E}-12$ & & & & & & & \\
\hline & & & & Th-228 & $2.2 E-13$ & $1.0 \mathrm{E}-03$ & & & & & & $2.2 E-16$ & & & & & & & \\
\hline & & & & Th-230 & 6.5E-13 & $1.0 E-03$ & & & & & & 6.5E-16 & & & & & & & \\
\hline & & & & $\frac{1 n-232}{0.230}+20$ & 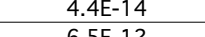 & 1.0 1.0 & & & & & & 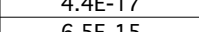 & & & & & & & \\
\hline & & & & $\begin{array}{l}\text { Pu-239 } \\
\text { Pus } 19\end{array}$ & $2.96-10$ & $\frac{1.0 E-03}{1.0-03}$ & & & & & & $2.9 E-13$ & & & & & & & \\
\hline & & & & Pu-240 & 1.8E-10 10 & $1.0 \mathrm{E}-03$ & & & & & & $1.8 \mathrm{E}-13$ & & & & & & & \\
\hline & & & & Am-241 & $\frac{1.55-10}{1.5 E-11}$ & $\frac{1.0 \mathrm{U}-\mathrm{C}-3}{1.0 \mathrm{E}}$ & & & & & & 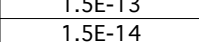 & & & & & & & \\
\hline & & & & U-234 & 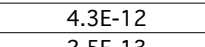 & $\begin{array}{l}1.0 \mathrm{OE}-03 \\
1.0-02\end{array}$ & & & & & & $\begin{array}{l}4.3 E-15 \\
.5-15\end{array}$ & & & & & & & \\
\hline & & & & $0-235$ & 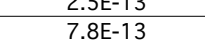 & 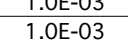 & & & & & & 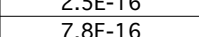 & & & & & & & \\
\hline
\end{tabular}


Attachment 1 - 2002 LLNL NESHAPs Annual Report Spreadsheet

\begin{tabular}{|c|c|c|c|c|c|c|c|c|c|c|c|c|c|c|c|c|c|c|c|}
\hline Building & Room/Area & Stack ID & Operation & Radionuclides & Annual Inventory & $\begin{array}{l}\text { Physical } \\
\end{array}$ & Stack & Stack & Stack & Control & Control Device & Estimated & $\frac{10 \operatorname{mrem} / \mathrm{SS}}{0.05}$ & $\begin{array}{l}\text { site-Wide Dose } \\
\text { interoctions }\end{array}$ & $\begin{array}{l}\text { sse Requirement } \\
\text { CDEn }\end{array}$ & $0.1 \mathrm{mrem} / \mathrm{s}$ & $\frac{1 y \text { Monitoring }}{\text { Direction }}$ & $\begin{array}{l}\text { Requirement } \\
\text { Unnabated } \\
\end{array}$ & \begin{tabular}{|l} 
Source \\
Cotaceory \\
\end{tabular} \\
\hline & & & & & $\begin{array}{l}\text { with Potential for } \\
\text { Release (Ci) }\end{array}$ & $\begin{array}{l}\text { State } \\
\text { Factor } \\
\end{array}$ & Height $(m)$ & $\begin{array}{c}\frac{D_{a}}{(m)}(m) \\
\end{array}$ & $\begin{array}{l}\frac{V_{\text {elocity }}}{(\mathrm{m} / \mathrm{s})} \\
\end{array}$ & Device(s) & $\begin{array}{l}\text { Abatement } \\
\text { Factor }\end{array}$ & \begin{tabular}{|c|} 
Annual Emissions \\
$(\mathrm{Ci})$
\end{tabular} & $\begin{array}{l}\text { Distance to } \\
\text { SWMEI (m) }\end{array}$ & \begin{tabular}{|l|} 
Direction \\
to SWMEI
\end{tabular} & \begin{tabular}{|c|} 
EDE \\
(mrem) \\
\end{tabular} & $\begin{array}{c}\text { Distance } \\
\text { to MEI }(m) \\
\end{array}$ & \begin{tabular}{|l|} 
Direction \\
to MEI
\end{tabular} & $\begin{array}{l}\text { Unabated } \\
\text { EDE (mrem) }\end{array}$ & \\
\hline $132 \mathrm{~N}$ & 2870 & FHE-6000/7000 & Preparation of urania and & u-234 & $3.5 E-06$ & $1.0 E-03$ & 38.1 & 2.13 & 11.2 & None & 1 & $3.5 \mathrm{E}-09$ & 1504 & $\mathrm{E}$ & $1.5 \mathrm{E}-07$ & 481 & sw & $2.4 \mathrm{E}-07$ & 1 \\
\hline & & & thoria aerogels & $\frac{u-235}{\mathrm{U}-238}$ & $\begin{array}{r}1.55-07 \\
3.3 \mathrm{E}-06\end{array}$ & $\frac{1.0 .0-03}{1.0 E-03}$ & & & & & & $\begin{array}{l}1.5-10-10 \\
3.3 \mathrm{E}-09\end{array}$ & & & & & & & \\
\hline & & & & Th-232 & 1.1.EE-06 & $1.0 \mathrm{EE}-03$ & & & & & & & & & & & & & \\
\hline 1325 & 2788 & FHE-6000/7000 & Transfer of uranium & U-238 & $5.7 E-10$ & $1.0 \mathrm{E}-03$ & 4.6 & 1.22 & 8.9 & None & 1 & $5.7 E-13$ & 1504 & $\mathrm{E}$ & 2.1E-11 & 481 & SW & 7.4E-11 & 2 \\
\hline & & & & $\begin{array}{l}u-235 \\
U-234\end{array}$ & $\frac{7.3 E-12}{5.3-11}$ & $\begin{array}{l}1.0 \mathrm{OE}-\mathrm{O}-3 \\
1.03\end{array}$ & & & & & & $\frac{7.3 \mathrm{E}-15}{5.3-14}$ & & & & & & & \\
\hline ilding 1 : & 1 houses the Iso & Sciences Division which applie & clear and isotope sciences to a & range of problen & including stockpile s & tewardship, & onproliferation, & feguard tec & ogies, forensic & e, and waste & gracterization and $\delta$ & tanalysis. & & & & & & & \\
\hline uilding 1 . & 1 also contains the & Chemistry and Materials Scienc & Environmental Services laboratory & vhere samples of $\mathrm{W}$ & aste streams and envir & onmental $m \mathrm{me}$ & lia (air, water, $\mathrm{s}$ & jil etc.) are anal & $\begin{array}{l}\text { yzed for their rat } \\
\text { yot }\end{array}$ & adionuclide content. & & & & & & & & & \\
\hline 151 & 1033 & FHE-2 & Evaporation and transfer & Cm-248 & $3.5 E-07$ & $1.0 \mathrm{E}-03$ & 12.8 & 0.41 & 7.8 & None & 1 & $3.5 \mathrm{E}-10$ & 1308 & $\mathrm{E}$ & 4.4E-07 & 768 & sw & $1.11-06$ & 2 \\
\hline & & & of solutions & $\frac{C m-246}{4-233}$ & $\begin{array}{l}8.3 E-07 \\
1.9 E-09\end{array}$ & $\begin{array}{l}1.0 \mathrm{OE}-03 \\
1.0-03\end{array}$ & 2 & & & & & $\begin{array}{l}8.3 E-10 \\
1.9-12 \\
\end{array}$ & & & ner & & -1 & 0 & \\
\hline & & & & $\mathrm{Np}-237$ & $\begin{array}{l}1.56-08 \\
.5-0.08\end{array}$ & $\begin{array}{l}1.0 \mathrm{E}-03 \\
.0-02\end{array}$ & & & & & & $\begin{array}{ll}3.5-5-1 \\
3.5-11\end{array}$ & & & & & & & \\
\hline 151 & $1034 \mathrm{~B}$ & FGBE-5/6 & & & & & & & & & & & 1200 & 5 & & & & & $=$ \\
\hline (5) & $1034 \mathrm{~B}$ & FGBE-5/6 & Sample preparation & $\begin{array}{lll}\text { Am-241 } \\
\text { Pu-2238 }\end{array}$ & $\begin{array}{l}2.7 .7-04 \\
3.0-03 \\
\end{array}$ & $\begin{array}{l}1.0 .0-03 \\
1.0 E-03 \\
\end{array}$ & 7.0 & 0.13 & 3.7 & Double HEPA & 0.0001 & $\begin{array}{l}2.7 .7-11 \\
3.0 E-10 \\
\end{array}$ & 1308 & $E$ & $1.5 E-07$ & $\frac{540}{584}$ & NWN & $\frac{1.3-3-02}{1.3 \mathrm{E}-02}$ & 2 \\
\hline & & & & $\begin{array}{l}\text { Pu-239 } \\
\text { Pu-240 }\end{array}$ & $\begin{array}{l}4.7-\mathrm{E}-03 \\
1.0 \mathrm{E}-03 \\
\end{array}$ & $\begin{array}{l}1.0 \mathrm{O}-\mathrm{E}-3 \\
1.0 \mathrm{E}-03 \\
\end{array}$ & & & & & & $\frac{4.7-10-10}{1.0-10}$ & & & & 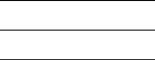 & & & 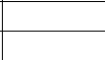 \\
\hline & & & & $\begin{array}{l}P u-241 \\
\text { Put-242 }\end{array}$ & $\begin{array}{l}1.6 \mathrm{E}-02 \\
4.7-09 \\
\end{array}$ & 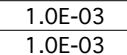 & & & & & & $\begin{array}{l}1.6 \mathrm{E}-09 \\
4.7-16\end{array}$ & & & & & & & z \\
\hline t & & & & 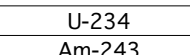 & $\begin{array}{l}3.3 E-08 \\
145-04\end{array}$ & $\begin{array}{l}1.0 \mathrm{OE}-03 \\
10-03\end{array}$ & & & & & & $\begin{array}{l}3.36-15 \\
144-11\end{array}$ & & & & & & & 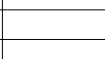 \\
\hline 151 & $1034 \mathrm{~B}$ & FGBE-7/8 & Radiochemical analysis of & $c t=249$ & $5.50 \mathrm{E}=0.5$ & $10=03$ & 70 & 0.13 & 3.7 & HEPA & 0.01 & $5.5-10$ & 1308 & $F$ & $6,3 E-07,-20$ & 540 & $w$ & $73-04$ & 1 \\
\hline & & & heavy element samples & $\begin{array}{lll}\text { Pu-238 } \\
\text { Puts }\end{array}$ & $\begin{array}{l}3.00-04 \\
100=-05 \\
\end{array}$ & $\frac{1.0-03}{1.0-03}$ & & 0.15 & & 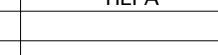 & & $\begin{array}{l}3.0 \mathrm{E}-09 \\
.0-010\end{array}$ & 000 & $L_{-}$ & (a) & (T) & & . & \\
\hline 151 & & & & & & & & & & & & & & & & & & & \\
\hline 151 & 1039 & FHE-43 & Transter of solutions & 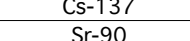 & $\begin{array}{l}4.60-10 \\
3.05-10\end{array}$ & $\begin{array}{l}1.06-03 \\
0=-03 \\
0.03\end{array}$ & 12.8 & 0.46 & 111.3 & None & 1 & $\begin{array}{l}4.6 E-13 \\
3.0 E=13\end{array}$ & 1308 & $E$ & $3.9 E-11$ & 768 & sw & $7.6 \mathrm{E}-11$ & 2 \\
\hline & & & & Gross alpha & $3.2 E-10$ & $1.0 E-03$ & & & & & & $3.2 \mathrm{E}-13$ & & & & & & & \\
\hline 151 & 1123 & FHE-41 & Evaporation and transfer & Pu-239 & $2.5 E-14$ & $1.0 E-03$ & 12.8 & 0.30 & 6.6 & None & 1 & $2.5 \mathrm{E}-17$ & 1308 & $E$ & $3.5 E-15$ & 768 & SW & $1.0 \mathrm{E}-14$ & 2 \\
\hline & & & of solutions & U-238 & $2.66-15$ & 1.0E-03 & & & & & & $2.66-18$ & & & & 584 & WNW & $1.0 E-14$ & \\
\hline 151 & $1131 \mathrm{~A}$ & Room Air & Preparation of aqueous samples & $\mathrm{H}-3$ & $4.5 E-07$ & $1.0 \mathrm{E}-03$ & NA & $\mathrm{NA}$ & $\mathrm{NA}$ & None & 1 & $4.5 E-10$ & 1308 & $E$ & $4.0 E-13$ & 540 & w & $5.8 \mathrm{E}-12$ & 1 \\
\hline & & & for stable isotope analysis & Cs-137 & $4.5 E-10$ & $1.0 \mathrm{E}-03$ & & & & & & $4.5 E-13$ & & & & & & & \\
\hline 151 & 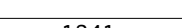 & & 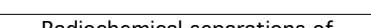 & & 10007 & & $+{ }^{2}$ & 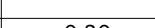 & $=0$ & & 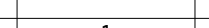 & & C. & & & & & & \\
\hline 151 & 1241 & FHEE 68 & $\begin{array}{l}\text { Radiochemicical separations of } \\
\text { uranium isotopes }\end{array}$ & $\begin{array}{l}-2-234 \\
U-235 \\
\end{array}$ & $\begin{array}{l}1.0 E-07 \\
1.0 E-08\end{array}$ & $\begin{array}{l}1.0 .0-03 \\
1.0 E-03\end{array}$ & 13.1 & 0.30 & 6.6 & None & 1 & 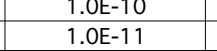 & 1308 & $\mathrm{E}$ & $6.0 E-09$ & 584 & WNW & $2.0 E-08$ & 1 \\
\hline 151 & 1303 & FHE-2000 & Sample t & U-238 & $8.4 \mathrm{E}-13$ & $1.0 E+00$ & 11.9 & 0.48 & 15.4 & None & 1 & $8.4 E-13$ & 1308 & $\mathrm{E}$ & $4.4 \mathrm{E}-08$ & 1125 & NNE & $8.2 E-08$ & 2 \\
\hline & & & and analysis (ICP-MS) & $\frac{U-235}{U-234}$ & $\begin{array}{l}3.9 E-14 \\
8.4 E-13\end{array}$ & $\frac{1.0 E+00}{1.0 E+00}$ & 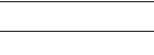 & 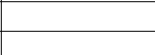 & & & & $\begin{array}{l}3.9 E-14 \\
8.45-13\end{array}$ & & & & & & & \\
\hline & & & & $\mathrm{U}-233$ & 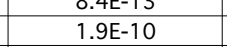 & $1.0 \mathrm{E}+00$ & & & & & & $\begin{array}{l}0.4 E-13 \\
1.95-10\end{array}-10$ & & 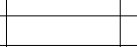 & & & & & \\
\hline & & & & 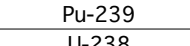 & $\begin{array}{l}3.1 E-10 \\
8.4 E-14\end{array}$ & $\frac{1.06+00}{10.00-03}$ & -5 & & & & & $\begin{array}{l}3.1 E-10 \\
845-17\end{array}$ & & & & & & & \\
\hline & & & & U-235 & 年 $3.9 E-15$ & $1.0 \mathrm{E}-03$ & & & & & & 3.9E-18 & & & & & & & \\
\hline & & & & U-234 & $8.4 E-14$ & 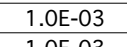 & & & & & & $8.45-17$ & & & & & & & \\
\hline & & & & $\begin{array}{l}\text { Pu-233 } \\
\text { Pu-239 }\end{array}$ & $\begin{array}{l}3.9 E-11 \\
3.1 E-11\end{array}$ & $\frac{1.0 .0-03}{1.0 E-03}$ & & & & & & $3.1 E-14$ & & & & & & & 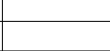 \\
\hline 151 & $1304 \& 1304 \mathrm{~A}$ & FHE-2000 & Preparation of samples for ICP/MS; & Cs-137 & $5.0 \mathrm{E}-07$ & $1.0 \mathrm{E}+00$ & 11.9 & 0.48 & 15.4 & None & 1 & $5.0 E-07$ & 1308 & $\mathrm{E}$ & $2.1 E-07$ & 1469 & $\mathrm{NE}$ & $3.3 E-07$ & 1 \\
\hline & & & analysis by ICP/MS & $\begin{array}{l}\text { Pu-239 } \\
1=233\end{array}$ & $\begin{array}{l}6.11-09 \\
10=08\end{array}$ & $\begin{array}{l}1.0 \mathrm{OE}-03 \\
100-03\end{array}$ & & & & & & $6.1 E-12$ & & & & & & & \\
\hline & & & & $\begin{array}{l}\mathrm{U}-233 \\
\mathrm{U}-234\end{array}$ & $\frac{1.0 \mathrm{E}-08}{1.0-11}$ & $\frac{1.0 .0-03}{1.0 E-03}$ & 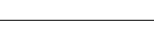 & & & & & $\frac{1.0 E-11}{1.0-14}$ & & -4 & & & & & $-C_{2}$ \\
\hline & & & & 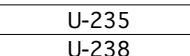 & $\begin{array}{l}1.0 \mathrm{E}-11 \\
10 \mathrm{E}-13 \\
\end{array}$ & $\begin{array}{l}1.0 \mathrm{OE}-03 \\
100-03\end{array}$ & & & & & & $\begin{array}{l}1.0 E-14 \\
1.0 E-16\end{array}$ & & & & & & & \\
\hline 151 & $1306 \mathrm{~A}$ & FHE-1000 & Acid cleaning of glassware & Cs-137 & $2.5 E-08$ & $10=03$ & 13.1 & 0.46 & 4.6 & None & 1 & $25 \mathrm{E}-11$ & 1308 & $E$ & $3,8=-10$ & 584 & WWW & $12 E-09$ & 1 \\
\hline & & & & Pu-239 & $2.55-09$ & 1.05 & & & & & & $2.5 E-12$ & 000 & & 我 & & & & \\
\hline & & & & $0-233$ & $\frac{2.5 E-11}{255-12}$ & $\begin{array}{l}1.0 \mathrm{E}-03 \\
0.03 \\
0.03\end{array}$ & & & & & & 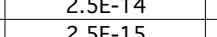 & & & & & & & \\
\hline & & & & $\mathrm{v}-235$ & $2.5 E-12$ & $1.0 \mathrm{E}-03$ & & & & & & $2.5 E-15$ & & & & & & & \\
\hline & & & & $\mathrm{U}-238$ & $2.5 E-13$ & $1.0 \mathrm{E}-03$ & & & & & & $2.5 E-16$ & & & & & & & \\
\hline 151 & 1318 & FHE-26 & Sample preparation & Pu-239 & $1.0 \mathrm{E}-09$ & $1.0 E-03$ & 13.1 & 0.36 & 7.4 & None & 1 & $1.0 E-12$ & 1308 & $E$ & $1.8 E-10$ & 768 & SW & $4.8 E-10$ & 2 \\
\hline & & & & Am-241 & $2.0 E-10$ & 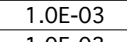 & & & & & & 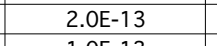 & & & & & & & \\
\hline & & & & & & & & & & & & & & & & & & & \\
\hline
\end{tabular}


Attachment 1 - 2002 LLNL NESHAPs Annual Report Spreadsheet

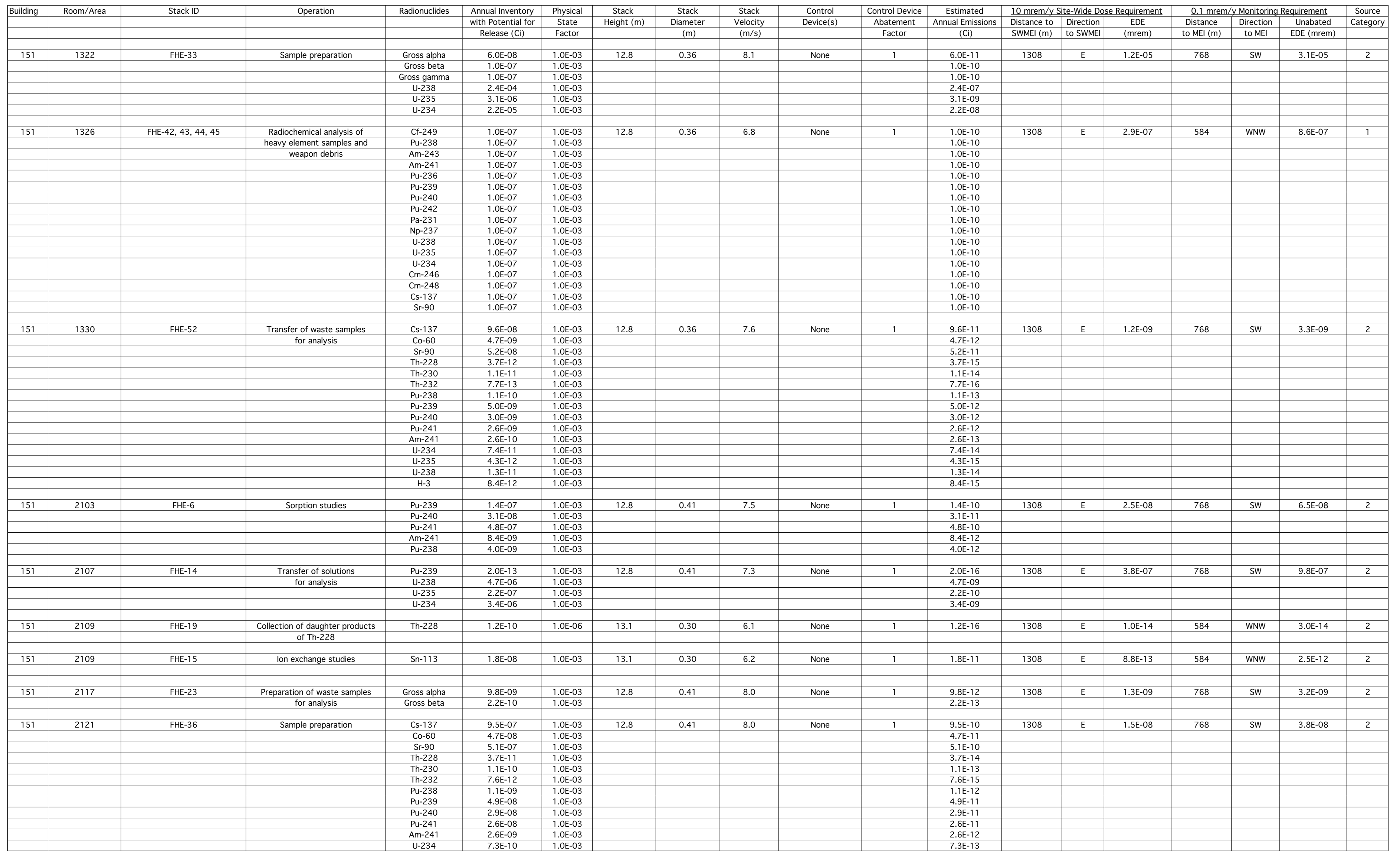


Attachment 1 - 2002 LLNL NESHAPs Annual Report Spreadsheet

\begin{tabular}{|c|c|c|c|c|c|c|c|c|c|c|c|c|c|c|c|c|c|c|c|}
\hline Building & Room/Area & Stack ID & Operation & Radionuclides & \begin{tabular}{|l} 
Annual Inventory \\
\end{tabular} & Physical & Stack & Stack & Stack & Control & Control Device & Estimated & $\frac{10 \mathrm{mrem} / \mathrm{y}}{0.0}$ & 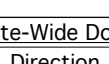 & $\begin{array}{l}\text { Requirement } \\
\text { Rent }\end{array}$ & $0.1 \mathrm{mrem}$ & $\begin{array}{l}\text { Monitorin } \\
\text { Doritction }\end{array}$ & $\begin{array}{c}\text { Requirement } \\
\text { Unabateted }\end{array}$ & $\begin{array}{c}\text { Source } \\
\text { Categar }\end{array}$ \\
\hline & & & & & \begin{tabular}{|l} 
with Potential for \\
Release (Ci)
\end{tabular} & $\begin{array}{l}\text { State } \\
\text { Factor }\end{array}$ & Height $(m)$ & $\begin{array}{c}\frac{D}{\text { Dimeter }} \\
(\mathrm{m})\end{array}$ & $\begin{array}{c}\frac{V}{\text { Velocity }} \\
(\mathrm{m} / \mathrm{s})\end{array}$ & Device(s) & $\begin{array}{l}\text { Abatement } \\
\text { Factor }\end{array}$ & $\begin{array}{l}\text { Annual Emissions } \\
\text { (ii) }\end{array}$ & $\begin{array}{l}\text { Distance to } \\
\text { SWMEI (m) }\end{array}$ & $\begin{array}{l}\text { Direction } \\
\text { to SWMEI }\end{array}$ & $\begin{array}{c}\text { EDE } \\
\text { (mrem) }\end{array}$ & $\begin{array}{l}\text { Distance } \\
\text { to MEI (m) }\end{array}$ & 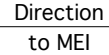 & $\begin{array}{l}\text { Unabated } \\
\text { EDE (mrem) }\end{array}$ & \\
\hline 151 & 2121 & (continued) & & U-235 & $4.33-11$ & $\begin{array}{l}1.06-03 \\
1.0-032\end{array}$ & & & & & & $4.36-14$ & & & & & & & \\
\hline & & & & $\begin{array}{l}-0.38 \\
\text { Pu-239 }\end{array}$ & 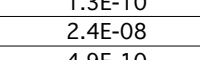 & $\begin{array}{l}\frac{1.06-03}{1.0 E-03} \\
1.02\end{array}$ & & & & & & $\begin{array}{l}1.5-13 \\
2.4-11 \\
20-11\end{array}$ & & & & & & & \\
\hline 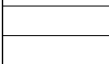 & & & & $\frac{S r-90}{H-3}$ & $\begin{array}{l}\frac{4.9 .9-10}{7.3 E-08} \\
\end{array}$ & $\begin{array}{l}\frac{1.0 E E-03}{1.0 E-03} \\
1.05\end{array}$ & & & & & & $\begin{array}{l}\frac{4.9 E-13}{7.3 E-11} \\
\end{array}$ & & & & & & & \\
\hline 151 & 2131 & $\begin{array}{ll}\text { FHE-56 } \\
\text { GFF-47 }\end{array}$ & $\begin{array}{l}\text { Transfer and processing of } \\
\text { Theros }\end{array}$ & Pu-239 & $\frac{2.0 E-11}{30=12}$ & $\begin{array}{l}1.0 E-06 \\
10=06\end{array}$ & $\frac{12.8}{112.8}-x-3$ & 0.41 & 7.3 & None & 1 & $\frac{2.0 E-17}{30-18}$ & 1308 & E & $3.7 E-15$ & 584 & wNw & $8.7 E-15$ & 1 \\
\hline & & FHE-47 & $\begin{array}{l}\text { glass sammles for } \\
\text { radiochemical analysis }\end{array}$ & $\begin{array}{l}\text { Put-238 } \\
\text { U-235 }\end{array}$ & $\begin{array}{l}3.0 E-12 \\
3.0 E-12 \\
\end{array}$ & $\begin{array}{l}\frac{1.0 E-06}{1.0 E-06} \\
1.06\end{array}$ & 12.8 & 0.41 & 7.8 & None & 1 & $\begin{array}{r}3.00-18 \\
3.0 E-18 \\
\end{array}$ & & & & & & & \\
\hline & & & & $\begin{array}{l}\text { U-238 } \\
\text { Cs-137 }\end{array}$ & $\begin{array}{l}3.0 \mathrm{E}-12 \\
6.0 \mathrm{E}-11 \\
-11\end{array}$ & 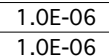 & & & & & & $\begin{array}{l}3.0 E-18 \\
660-17\end{array}$ & & & & & & & \\
\hline & & & & St-90 & $\begin{array}{l}0.0 E-11 \\
6.0 E-11\end{array}$ & $\begin{array}{l}1.0 E-06 \\
1.06\end{array}$ & - & & - & & - & 6.0E-17 & & & & & & & - \\
\hline & & & & $\begin{array}{l}\text { Eu-152 } \\
\text { Eut-154 }\end{array}$ & $\frac{6.0 \mathrm{O}-12}{6.0-12}$ & 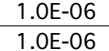 & & & & & 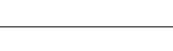 & $\begin{array}{l}6.0 E-18 \\
6.0 E-18\end{array}$ & & & & & & & 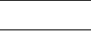 \\
\hline 151 & 2133 & FHE-57 & Swipe sample analysis & Gross alpha & $1.4 \mathrm{E}-14$ & $1.0 \mathrm{E}-03$ & 12.8 & 0.41 & 8.1 & None & 1 & $1.4 E-17$ & 1308 & $\mathrm{E}$ & $1.8 E-15$ & 768 & SW & $4.5 E-15$ & 2 \\
\hline 151 & 2143 & FHE-63 & Transfer of standards for & ${ }_{H-3}$ & $3.6 \mathrm{E}-12 \mathrm{C}, \mathrm{C}$ & $1.0 \mathrm{E}-03$ & 12.8 & 0.41 & $8.2>3$ & None & 1 & $3.6 E-15$ & 1308 & $\mathrm{E}$ & $8.7 E-19$ & 768 & SW & $215-18$ & 2 \\
\hline & & & $\begin{array}{l}\text { the analysis of environmental } \\
\text { sampmes }\end{array}$ & & & & & & & & & & & & & & & & \\
\hline & & & $\begin{array}{c}\text { far } \\
\text { for envirionmental samples }\end{array}$ & & & & & & & & & & & & & & & & \\
\hline 151 & 2147 & FHE-67 & Transfer of yield tracers for & Pu-242 & $7.1 \mathrm{E}-13$ & $1.0 \mathrm{E}-03$ & 12.8 & 0.41 & 8.0 & None & 1 & 7.1E-16 & 1308 & $\mathrm{E}$ & $6.5 E-14$ & 768 & sw & $1.6 \mathrm{E}-13$ & 2 \\
\hline 151 & 2149 & FHE-78 & Transfer of yield tracers & Pu-238 & $2.0 E-14$ & $1.00-03$ & 13.1 & 0.41 & 7.8 & None & 1 & $2.0 E-17$ & 1308 & $\mathrm{E}$ & $6.0 E-13$ & 768 & sw & $1.5 E-12$ & 2 \\
\hline & & & $\begin{array}{l}\text { samples as yield trace } \\
\text { during anylysis }\end{array}$ & $\begin{array}{l}\text { Pu-239 } \\
\text { Put-20 }\end{array}$ & $\begin{array}{l}4.0 E-14 \\
4.0=14\end{array}$ & $\begin{array}{l}1.00-03 \\
1.0=0.03\end{array}$ & 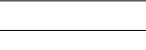 & 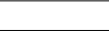 & 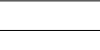 & & & $\begin{array}{l}4.0 E-17 \\
4.0=17\end{array}$ & & 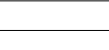 & & & & & 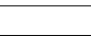 \\
\hline & & & & $\begin{array}{l}\text { Pu-c40 } \\
\text { Pu-242 }\end{array}$ & $\begin{array}{l}3.0 E-12 \\
3.0 E-12 \\
4\end{array}$ & 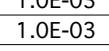 & & & & & & $\begin{array}{l}4.0 E-17 \\
3.0 E-15\end{array}$ & & & & & & & \\
\hline & & & & U-232 & $\frac{1.0 E-12}{0.05-12}$ & $\begin{array}{l}1.00-03 \\
1.0=0.03\end{array}$ & & & - & & & $1.00-15$ & & & & & & & \\
\hline & & & & $\mathrm{U}-238$ & $\begin{array}{ll}3.0 E-15 \\
4.0 E-15\end{array}$ & 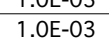 & & & & & & $\begin{array}{l}3.0 E-16 \\
4.00-18\end{array}$ & & - & & & & & - \\
\hline & & & & Cs-134 & $\begin{array}{l}1.44-12 \\
0.1-12\end{array}$ & $1.00-03$ & & & & & & $1.4 E-15$ & & & & & & & \\
\hline & & & & Cs-137 $437-1$ & $8.1 \mathrm{E}-13$ & $1.0 E=-0 S$ & & & & & $x_{0}$ & $8.1 E-16$ & & & & & & & \\
\hline 151 & $2302 \mathrm{~A}$ & FHE-9 & Waste treatability studies & $\begin{array}{c}\mathrm{H}-3 \\
\mathrm{U}-235\end{array}$ & $\frac{1.0 E-04}{6.11-14}$ & $\begin{array}{l}1.0 \mathrm{E}-03 \\
1.0 \mathrm{E}-03 \\
\mathrm{n}\end{array}$ & 13.1 & 0.41 & 7.5 & None & 1 & $\begin{array}{l}\frac{1.0 E-07}{6.11-17} \\
\end{array}$ & 1308 & E & $2.1 E-11$ & 768 & sw & $5.9 E-11$ & 2 \\
\hline 151 & 2308 & FHE-16 & Ceramics leaching studies & Pu-239 & $1.9 E-02$ & $1.0 E-03$ & 12.8 & 0.41 & 7.3 & Double HEPA & 0.0001 & $1.9 \mathrm{E}-09$ & 1308 & $E$ & $3.5 E-07$ & 768 & Sw & $8.9 E-03$ & 2 \\
\hline & & & & $\begin{array}{l}\text { Pu-240 } \\
\text { Puu-241 }\end{array}$ & $\begin{array}{l}4.2 E-03 \\
6.8 E-02 \\
6-02\end{array}$ & $\begin{array}{l}1.00-03 \\
1.0=0.03\end{array}$ & & & & & & $\begin{array}{l}4.2 E-10 \\
6.8 E-09\end{array}$ & & & & & & & \\
\hline & & & & Am-241 & $1.1 \mathrm{EE}-03$ & $\frac{1.0 E-03}{1.03}$ & & & & & & $1.1 \mathrm{E}-10$ & & - & & & & & 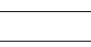 \\
\hline & & & & $\begin{array}{l}P u-238 \\
u-234\end{array}$ & $\begin{array}{l}5.6 E=-04 \\
22-07\end{array}$ & 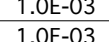 & & & & & & $\begin{array}{l}5.6 E-11 \\
22-14\end{array}$ & & 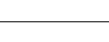 & & & & & 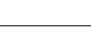 \\
\hline & & & & $\mathrm{U}-235$ & $9.7 E-09$ & $1.0 \mathrm{E}-03$ & & & & & & $9.7 E-16$ & & & & & & & \\
\hline & & & & $0-238$ & 2.1E-07 & $1.0 E-03$ & & & & & & 2.1E-14 & & & & & & & 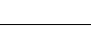 \\
\hline 151 & 2308 & FHE-12 & Ceramics leaching studies & $U-234$ & $6.6 E-07$ & $1.0 E-03$ & 13.1 & 0.41 & 7.8 & None & 1 & $6.65-10$ & 1308 & $E$ & $5.9 E-08$ & 768 & sw & $1.4 \mathrm{E}-07$ & 2 \\
\hline & & & & $\mathrm{u}-238$ & $6.11-07$ & 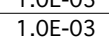 & 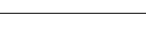 & & 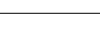 & & & 列 & & & & & & & \\
\hline 151 & 2312 & FHE-21 & Solubility studies & Np-237 & $2.77-08$ & $1.00-03$ & 12.8 & 0.41 & 7.6 & Double HEPA & 0.0001 & $2.78-15$ & 1308 & $\mathrm{E}$ & $4.9 E-13$ & 768 & sw & $1.2 \mathrm{E}-08$ & 2 \\
\hline 151 & 2312 & FHE-21 & Solubility studies & Np-237 & $6.4 \mathrm{E}-09$ & $1.0 \mathrm{E}-03$ & 12.8 & 0.41 & 7.1 & None & 1 & $6.4 \mathrm{E}-12$ & 1308 & $E$ & $1.2 \mathrm{E}-09$ & 768 & SW & $3.0 \mathrm{E}-09$ & 2 \\
\hline 151 & 2318 & FHE-22 & Transfer of sample solutions & Pu-242 & $1.9 \mathrm{E}-09$ & $1.0 \mathrm{E}-03$ & 9.8 & 0.41 & 8.0 & Double HEPA & 0.0001 & $1.9 \mathrm{E}-16$ & 1308 & E & $2.5 E-14$ & 768 & sw & $7.8 \mathrm{E}-10$ & 2 \\
\hline 151 & 2322 & FHE-38 & Transfer and processing of & Cs-137 & $3.4 E-07$ & $1.0 E-03$ & 12.8 & 0.41 & 8.1 & None & 1 & $3.4 E-10$ & 1308 & $E$ & $5.6 E-09$ & 768 & Sw & 1.44-08 & 2 \\
\hline & & & of waste sludge samples & Co-60 & $1.7 E-08$ & $1.00-03$ & & & & & & $-7=0$ & & 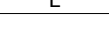 & & & & & \\
\hline & & & for TCLP, STLC, pH, \% moisture, & Sr-90 & $1.8 \mathrm{E}-07$ & $1.0 \mathrm{E}-03$ & & & & & & $1.8 E-10$ & & & & & & & \\
\hline & & & TTLC analyses & $\begin{array}{l}\text { Th-2228 } \\
\text { Th-230 }\end{array}$ & $\begin{array}{l}1.3 \mathrm{E}-11 \\
3.9 \mathrm{E}-11\end{array}$ & $\frac{1.0 E-03}{1.0 E-03}-13$ & & & & & & $\frac{1.3 \mathrm{E}-14}{3.9-14}$ & & & & & & & \\
\hline & & & & Th-232 & $2.8 E-12$ & $1.0 \mathrm{E}-03$ & & & & & & $2.8 \mathrm{E}-15$ & & & & & & & \\
\hline & & & & $\begin{array}{l}\text { Pu-238 } \\
\text { Puu-239 }\end{array}$ & $\begin{array}{l}3.9 E-10 \\
18-08\end{array}$ & $\begin{array}{l}1.0 E-03 \\
10=0.03\end{array}$ & & & & & & $\begin{array}{l}3.9 E-13 \\
18 E-11 \\
150\end{array}$ & & & & & & & \\
\hline & & & & $\begin{array}{l}\text { Pur-240 } \\
\text { Pon }\end{array}$ & $1.1 .6-08$ & $\frac{1.0 E-03}{1.06}<-10$ & & & & & & $\frac{1.16-11}{1.11}$ & & & & & & & \\
\hline & & & & Pu-241 & 9.4E-09 & $1.0 E-03$ & & & & & & $9.4 E-12$ & & & & & & & \\
\hline & & & & 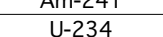 & $226=10$ & 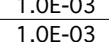 & & & & & & $\begin{array}{l}9.446-13 \\
2.6 E-13 \\
\end{array}$ & & & & & & & \\
\hline & & & & U-235 & $1.5 E-11$ & $1.0 E-03$ & & & & & & $1.5 E-14$ & & & & & & & \\
\hline & & & & $\mathrm{U}-238$ & $4.7 E-11$ & $1.0 \mathrm{E}-03$ & & & & & & $4.7 E-14$ & & & & & & & \\
\hline & & & & Gross alpha & $\begin{array}{l}9.0 \mathrm{E}-09 \\
21 \mathrm{x}-1\end{array}$ & $\begin{array}{l}1.0 E=03 \\
1.0=03\end{array}$ & & & & & & $9.0 E-12$ & & & & & & & \\
\hline & & & & ross bet & 2.1T-10 210 & $\begin{array}{l}1.0 E=03 \\
1.0=03\end{array}$ & & & & & & 2., LE-13 & & & & & & & \\
\hline
\end{tabular}




\section{Attachment 1 - 2002 LLNL NESHAPs Annual Report Spreadsheet}

\begin{tabular}{|c|c|c|c|c|c|c|c|c|c|c|c|c|c|c|c|c|c|c|c|}
\hline Building & Room/Area & Stack ID & Operation & Radionuclides & 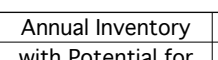 & $\begin{array}{l}\text { Physical } \\
\text { Stato }\end{array}$ & Stack & $\begin{array}{l}\text { Stack } \\
\text { Ditemotor }\end{array}$ & $\begin{array}{l}\text { Stack } \\
\text { Vencoits }\end{array}$ & Control & \begin{tabular}{|l|} 
Control Device \\
\end{tabular} & Estimated & $10 \mathrm{mrem} / \mathrm{y}$ & Site-Wide Dos & se Requirement & $0.1 \mathrm{mrem}$ & y Monitoring & Requirement & Source \\
\hline & & & & & $\begin{array}{l}\text { with Potontiat for } \\
\text { Release (i) }\end{array}$ & $\begin{array}{l}\text { State } \\
\text { Factor }\end{array}$ & Height (m) & $\begin{array}{l}\text { Diameter } \\
\text { (m) }\end{array}$ & $\begin{array}{l}\text { Velocity } \\
(m / s)\end{array}$ & Device(s) & $\begin{array}{l}\text { Abatament } \\
\text { Factor } \\
\end{array}$ & $\begin{array}{l}\text { Annual Emissions } \\
\text { (Ci) }\end{array}$ & \begin{tabular}{|l|} 
Distance to \\
SWMEI (m) \\
\end{tabular} & \begin{tabular}{|l|} 
Direction \\
to SWMEI
\end{tabular} & \begin{tabular}{|l|l|l} 
EDE \\
(mrem)
\end{tabular} & $\begin{array}{l}\text { Distance } \\
\text { to ME(m) }\end{array}$ & \begin{tabular}{|l|} 
Direction \\
to MEI
\end{tabular} & $\begin{array}{c}\text { Unabatad } \\
\text { EDE (mrem) } \\
\end{array}$ & category \\
\hline 151 & 2326 & FHE-39 & Chemical analysis of waste & Cs-137 & $3.88-07$ & $1.0 E+00$ & 12.8 & 0.41 & 7.6 & None & 1 & $3.8 \mathrm{E}-07$ & 1308 & $\mathrm{E}$ & $8.8 E-06$ & 768 & sw & $2.2 E-05$ & 2 \\
\hline & & & & $\frac{C 0-60}{S S-90}$ & $\begin{array}{l}1.8 \mathrm{E}-08 \\
2.0 \mathrm{E}-07\end{array}$ & $\begin{array}{l}1.0 E+00 \\
1.0 .0+00\end{array}$ & & & & & & $\begin{array}{l}1.8 \mathrm{E}-08 \\
2.0 \mathrm{0}-\mathrm{n}\end{array}$ & & & & & & & \\
\hline & & & & Th-228 & $\begin{array}{l}2.5 E-11 \\
1.5-11\end{array}$ & $\frac{1.00+00}{1.0+00}$ & & & & & & $\frac{2.0-5-1}{1.5-11}$ & & & & & & & \\
\hline & & & & $\begin{array}{l}\text { Th-230 } \\
\text { Th-232 }\end{array}$ & $\begin{array}{l}4.3 E-11 \\
3.0 E-12\end{array}$ & $\begin{array}{l}1.0 .0+00 \\
1.0 E+00\end{array}$ & & & & & & $\begin{array}{l}4.3 E-11 \\
3.06-12 \\
3\end{array}$ & & & & & & & \\
\hline & & & & $\begin{array}{l}\text { Put-238 } \\
\text { Put-239 }\end{array}$ & $\begin{aligned} 4.44-10 \\
2.0 E-08 \\
\end{aligned}$ & $\begin{array}{l}1.0 .0+00 \\
1.0+00 \\
\end{array}$ & & & & & & 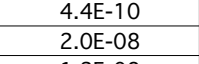 & & & & & & & \\
\hline & & & & $\begin{array}{l}\text { Pu-240 } \\
\text { Pu-241 }\end{array}$ & $\begin{array}{l}1.2-2-08 \\
1.0-08 \\
\end{array}$ & $\begin{array}{l}1.0 .0+00 \\
1.0++00\end{array}$ & & & & & & $\begin{array}{r}1.2 E-08 \\
1.0 E-08 \\
\end{array}$ & & & & & & & \\
\hline & & & & $\begin{array}{ll}A m-241 \\
U \mathrm{U}-234\end{array}$ & $\begin{array}{l}1.0 \mathrm{E}-09 \\
2.9 \mathrm{E}-10\end{array}$ & $\frac{1.0 \mathrm{OE}+00}{1.0 \mathrm{E}+00}$ & & & & & & $\begin{array}{l}1.0 \mathrm{O}-9 \mathrm{-9} \\
2.99-10\end{array}$ & & & & & & & \\
\hline & & & & $\begin{array}{l}U-235 \\
U-238 \\
-1\end{array}$ & $\begin{array}{l}1.7 \mathrm{E}-11 \\
5.2 \mathrm{E}-11\end{array}$ & $\begin{array}{l}1.0 E+00 \\
1.0 .0+0\end{array}$ & & & & & & $\begin{array}{l}\frac{1.7 \mathrm{E}-11}{55.2-11} \\
\end{array}$ & & & & & & & \\
\hline & & & & Gross alpha & $\begin{array}{l}3.06-08 \\
3.0-08\end{array}$ & $1.0+0+00$ & & & & & & $3.00-08$ & & & & & & & \\
\hline & & & & $\begin{array}{l}\text { Gross beta } \\
\mathrm{H}-3\end{array}$ & $\begin{array}{l}0.06-10 \\
9.0 E-08\end{array}$ & $\begin{array}{l}1.0 .0+00 \\
1.0++00\end{array}$ & & & & & & $\begin{array}{l}0.00=-10 \\
9.06-08\end{array}$ & & & & & & & \\
\hline 151 & $2326 \mathrm{~A}$ & FHE- 40 & Preparation of environmental & Gross alpha & $1.0 \mathrm{E}-09$ & $1.0 \mathrm{E}-03$ & 12.8 & 0.30 & 3.9 & None & 1 & $1.0 \mathrm{E}-12$ & 1308 & $E$ & $1.4 \mathrm{E}-10$ & 584 & WNW & $5.4 \mathrm{E}-10$ & 2 \\
\hline & & & & & & & & & & & & & & & & & & & \\
\hline 151 & 2330 & FHE-50 & $\begin{array}{l}\text { Analysis of standards for } \\
\text { waste samples; nalysis }\end{array}$ & $\frac{P u-239}{H-3}$ & $\begin{array}{l}3.9 E-09 \\
5.7 E-12\end{array}$ & $\begin{array}{l}1.0 E-03 \\
1.0-03\end{array}$ & 12.8 & 0.41 & 7.5 & None & 1 & $\begin{array}{l}3.9 \mathrm{E}-12 \\
5.7-15 \\
\end{array}$ & 1308 & $E$ & $5.1 E-10$ & 768 & sw & $1.3 \mathrm{E}-09$ & 2 \\
\hline & & & of waste samples & $\mathrm{H}-3$ & $9.0 \mathrm{E}-09$ & $1.0 \mathrm{E}+00$ & & & & & & $9.0 \mathrm{E}-09$ & & 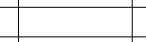 & & & 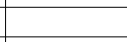 & & \\
\hline 151 & 2344 & FHE-65 & Preparation of organic liquid & $\mathrm{H}-3$ & $1.0 E-09$ & $1.0 \mathrm{E}-03$ & 12.8 & 1.33 & 7.9 & None & 1 & $1.0 E-12$ & 1308 & $E$ & $3.0 \mathrm{E}-11$ & 1469 & NE & $1.2 E-10$ & 1 \\
\hline & & & $\begin{array}{c}\text { samples for } 6 \text { VCC analysis } \\
\text { by G/MS }\end{array}$ & $\begin{array}{l}C-14 \\
S r-90 \\
S c-137\end{array}$ & $\begin{array}{l}\frac{1.0 E-10}{1.0 E-10} \\
1.0=10\end{array}$ & $\begin{array}{l}1.0-3 \\
1.0-0.3 \\
10-03\end{array}$ & & & & & & $\begin{array}{l}\frac{1.06-14}{1.0-13} \\
.0-12\end{array}$ & & & & & & & \\
\hline & & & & $\begin{array}{l}\frac{15-137}{E u-152} \\
\text { Eut }\end{array}$ & $\begin{array}{l}\frac{1.0 E-10}{1.0 E-11}-1 \\
1\end{array}$ & $\begin{array}{l}1.0-0=3 \\
1.0 E-03 \\
\end{array}$ & & & & & & $\begin{array}{l}\frac{1.0 E-13}{1.0 E-14} \\
\end{array}$ & & 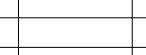 & & & & & \\
\hline & & & & $\frac{U-238}{U-235}$ & $\begin{array}{l}\frac{1.0 E E-09}{1.0 E-10} \\
1.04\end{array}$ & $\begin{array}{l}1.0 E-3 \\
1.0-03 \\
\end{array}$ & & & & & & $\begin{array}{l}\frac{1.0 E E-12}{1.0 E-13} \\
1.13\end{array}$ & & & & & & & \\
\hline & & & & $\begin{array}{l}\text { Pu-239 } \\
\text { Put-238 }\end{array}$ & $\begin{array}{l}1.0 E-10 \\
1.0 E=10\end{array}$ & $\begin{array}{l}1.0 \mathrm{E}-03 \\
1.0-\mathrm{E}=3 \\
\end{array}$ & & & & & & $\begin{array}{l}1.0 \mathrm{OE}-13 \\
1.0 \mathrm{E}-13\end{array}$ & & & & & & & \\
\hline & & & & Am-241 & $1.00-10$ & $1.0 \mathrm{E}-03$ & & & & & & $1.0 E-13$ & & & & & & & \\
\hline 151 & 2348 & FHE-75 & Freeze trapping/analysis of tritium & $\mathrm{H}-3$ & $1.5 E-13$ & $1.0 E+00$ & 12.8 & 0.41 & 8.7 & None & 1 & $1.5 E-13$ & 1308 & $E$ & $3.7 E-17$ & 768 & sw & $8.7 E-17$ & 2 \\
\hline 151 & 2350 & FHE-76 & Transfer of tracer solutions & Pu-242 & $1.2 E-12$ & $1.0 \mathrm{E}-03$ & 12.8 & 0.41 & 8.4 & None & 1 & $1.2 E-15$ & 1308 & $\mathrm{E}$ & $4.6 E-13$ & 768 & sw & $1.1 \mathrm{E}-12$ & 2 \\
\hline & & & & Am-243 & $\begin{array}{l}5.7 \mathrm{E}-13 \\
3.3-13\end{array}$ & $\begin{array}{l}1.0 \mathrm{E}-03 \\
1.0-03\end{array}$ & & & & & & $\frac{5.7 \mathrm{E}-16}{3.3-16}$ & & & & & & & \\
\hline & & & & Pu-239 & $\begin{array}{l}7.3 E-13 \\
865-14\end{array}$ & $\begin{array}{ll}1.0 E-03 \\
10-0.3\end{array}$ & & & & & & $\begin{array}{l}7.3 E-16 \\
0.9-17 \\
\end{array}$ & & & & & & & \\
\hline & & & & $\frac{A m-241}{U-234}$ & 6. $6.8 E-11$ & $1.0 \mathrm{E}-03$ & & & & & & $\begin{array}{ll}0.0 E-11 \\
6.8 E-14\end{array}$ & & & & & & & \\
\hline & & & & U-235 & $8.5 E-09$ & $\begin{array}{ll}1.0 E-03 \\
10-0.3\end{array}$ & & & & & & $8.5 E-12$ & & & & & & & \\
\hline dinas & 5 and 177 were & art of the lltranium Atomic Vanort & Leser Isotone Senaration (U-AV/JS) & ronaram affliated w & ith The United States & Finghent & Ormoration (IISE & C) In lune 1999 & 9 IISEC GUSpende & ded further develonmen & It of the II-AV|IS t & 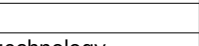 & & & & & & & \\
\hline dining & $\begin{array}{l}5 \text { and } 1 / 7 \text { were } \\
\text { underwent dec }\end{array}$ & 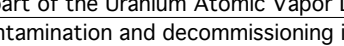 & $\begin{array}{l}\text { Laser Isotope separation (UA-AVLIST) } \\
\text { in early 2002, and the saling sys }\end{array}$ & 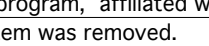 & It Ine United States & Enrichiment & Orporation (USE & C). In June 1999 & 9, uste suspeñac & ded further cevelopmen & tit of the U-AVLIS & ectnology. & & & & & & & \\
\hline 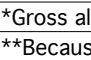 & ha and Gross beta & $\begin{array}{l}\text { missions are continuously monitor } \\
\text { ins }\end{array}$ & red at the stack. Monitoring data, rat & her than the invento & y approach, are used & to determin & emissions. & 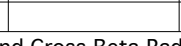 & tion & & & & & & & & & & \\
\hline 175 & 2 & 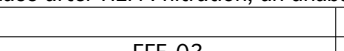 & (n) & 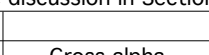 & & the & 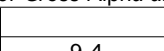 & 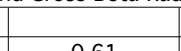 & 15 & HCDA & 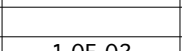 & (20) & 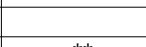 & 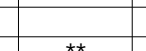 & (20) & $t$ & t* & $=0$ & T \\
\hline & 103 & FFE-01 & & Gross beta & * & $N A$ & 9.4 & 0.61 & 4.6 & & $1.0 E=-02$ & $\begin{array}{l}0.0 E+00 \\
0.0 E+00\end{array}$ & & & $0.0 E+U 0$ & & & & 3 \\
\hline & $\frac{112}{112}$ & $\begin{array}{l}\text { THE-02 } \\
\text { FHE-01 }\end{array}$ & & & & & $\begin{array}{l}6.6 \\
6.7\end{array}$ & 0.36 & 6.4 & & & & & & & & & & \\
\hline & 128 & FHE-2000 & & & & & 8.9 & 0.59 & 4.6 & & & & & & & & & & \\
\hline & & & & & & & & & & & & & & & & & & & \\
\hline & 1020 & FHE-22 & Operations discontinued & Gross alpha & * & $\mathrm{NA}$ & 6.4 & 0.30 & 8.9 & HEPA & 0.01 & $0.0 E+00$ & 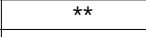 & ${ }^{* *}$ & $0.0 E+00$ & ** & ** & ${ }^{* *}$ & 3 \\
\hline & & & & & & & & & & & & & & & & & & & \\
\hline $\begin{array}{l}\text { Bulding } \\
\text { The acce }\end{array}$ & 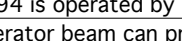 & $\begin{array}{l}\text { Division for the Physics and Space } \\
\text { Duce small wantititis of shortrtive }\end{array}$ & ede Technology Directorate. The facility & y houses a high-energ & yy linear accelerator $(\mathrm{l} / \mathrm{L}$ & 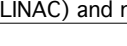 & search laborato: & & & & & & & & & & & & \\
\hline 194 & $B 122$ & TE-FE4 & Linac accelerator vault & $0-15$ & $6.0 E-02$ & $1.0 E+00$ & 30.5 & 1.37 & 4.5 & None & 1 & $6.0 \mathrm{E}=02$ & 1525 & SSE & $5.2 E-07$ & 538 & NE & $5.3 \mathrm{E}-05$ & 2 \\
\hline & & (Target Exhaust) & & $\mathrm{N}-13$ & $1.1 \mathrm{E}-01$ & $1.0 \mathrm{E}+00$ & & & & & & $1.1 \mathrm{E}-01$ & & & & & & & \\
\hline
\end{tabular}


Attachment 1 - 2002 LLNL NESHAPs Annual Report Spreadsheet

\begin{tabular}{|c|c|c|c|c|c|c|c|c|c|c|c|c|c|c|c|c|c|c|c|}
\hline Building & Room/Area & Stack ID & Operation & Radionuclides & \begin{tabular}{|l|} 
Annual Inventory \\
\end{tabular} & $\begin{array}{l}\text { Physical } \\
\end{array}$ & Stack & Stack & 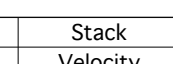 & $\begin{array}{l}\text { Control } \\
\text { Oniso(s) }\end{array}$ & Control Device & 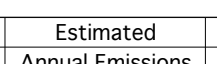 & $\frac{10 \mathrm{mrem} / \mathrm{ys}}{0 \mathrm{~s}}$ & $\begin{array}{l}\text { Site-Wide Dos } \\
\text { Sitions }\end{array}$ & se Requirement & $0.1 \mathrm{mrem} /$ & /y Monitoring & gequirement & Source \\
\hline & & & & & \begin{tabular}{|l} 
with Potential for \\
Release (i)
\end{tabular} & $\begin{array}{l}\text { State } \\
\text { Factor } \\
\end{array}$ & Height $(m)$ & $\frac{D^{2} \text { Diameter }}{(\mathrm{m})}$ & 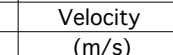 & $\begin{array}{l}\text { Device(s) } \\
\end{array}$ & $\begin{array}{l}\text { Abatement } \\
\text { Factor }\end{array}$ & \begin{tabular}{|l|} 
Annual Emissions \\
(Ci)
\end{tabular} & $\begin{array}{l}\text { Distance to } \\
\text { SWWEI (m) }\end{array}$ & $\begin{array}{l}\text { Direction } \\
\text { to SWMEI } \\
\end{array}$ & $\begin{array}{l}\frac{E D E}{\text { EDrem) }} \\
\text { (mrem }\end{array}$ & $\begin{array}{l}\text { Distance } \\
\text { to MEI (m) }\end{array}$ & \begin{tabular}{|l|} 
Direction \\
to MEE \\
\end{tabular} & $\begin{array}{c}\text { Unabated } \\
\operatorname{EDE}(\text { mrem) }\end{array}$ & Category \\
\hline 194 & B124 & TE-FE4 & Storage & Na-22 & $5.0 E-05$ & $\frac{1.0 E-03}{1}$ & 30.5 & 1.37 & 4.5 & None & & $5.0 \mathrm{E}-08$ & 1525 & SSE & & 538 & & & \\
\hline & & & & $\frac{\mathrm{U}-233}{\mathrm{U}-234}$ & $\frac{1.2 \mathrm{E}-05}{6.05-09}$ & $\begin{array}{l}1.0 \mathrm{OE}-06 \\
1.0-06\end{array}$ & $-{ }_{0}$ & -2 & & & & $\frac{1.2 \mathrm{E}-11}{6.0-15}$ & & 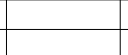 & & & 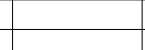 & & 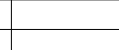 \\
\hline & & & & $0-235$ & $3.9 E-06$ & $1.0 \mathrm{E}-06$ & -5 & -5 & & & & $3.9 E-12$ & & & & & & & \\
\hline & & & & 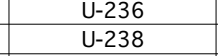 & $\begin{array}{l}3.5 \mathrm{E}-08 \\
1.0-04\end{array}$ & 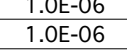 & & 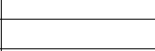 & & & $x_{0}$ & $\frac{3.5-14}{1.0 E-10}$ & & & & & 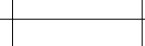 & & 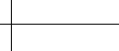 \\
\hline 194 & B130 & TE-FE4 & Positron beam generation & $0-15$ & $5.5 E-01$ & $10 E+00$ & 30.5 & 1.37 & 4.5 & None & 1 & $5.5 \mathrm{E}-01$ & 1525 & SSE & $5,2 E-06$ & 538 & $\mathrm{NE}$ & $5,2 E-04$ & 2 \\
\hline & & & & $\mathrm{N}-13$ & $1.1 \mathrm{E}+00$ & $1.0 \mathrm{E}+00$ & & & & & & $1.1 \mathrm{E}+00$ & & & & & & & \\
\hline 194 & 1131 & Room Air & Positron materials science & $\mathrm{Na}-22$ & $3.66-06$ & $1.0 \mathrm{E}-03$ & $\mathrm{NA}$ & $\mathrm{NA}$ & $\mathrm{NA}$ & None & 1 & $3.6 \mathrm{E}-09$ & 1525 & ESE & $2.4 E-09$ & 532 & w & $7.06-08$ & 2 \\
\hline & & & experiments & & & & & & & & & & & & & & & & \\
\hline Building 2 & is administered & oy the Physics and Space Technolc & gy Directorate (formerly the Physic & al Sciences Directorat & te) for miscellaneous : & thysics exper & iments. & & & & & & & & & & & & \\
\hline The curre & radionuclide em & sions are due to contamination frc & $\mathrm{m}$ past operations of the rotating to & arget neutron source, & which is no longer in & operation. & & & & & & & & & & & & & \\
\hline 212 & 174 & FHE-7 & Contamination & $\mathrm{H}-3$ & $1.7 \mathrm{E}-02$ & $1.0 E-06$ & 4.3 & 0.5 & 0.5 & None & 1 & $1.7 \mathrm{E}-08$ & 1278 & ENE & $8.5 E-12$ & 38 & SW & $3.4 \mathrm{E}-10$ & 2 \\
\hline 212 & 184 & Room Air & Contamination & $\mathrm{H}-3$ & $1.0 \mathrm{E}-03$ & $1.0 \mathrm{E}-06$ & $\mathrm{NA}$ & NA & NA & None & 1 & $1.0 \mathrm{E}-09$ & 1278 & ENE & $5.0 E-13$ & 38 & SW & $2.2 E-11$ & 2 \\
\hline The 231 & mplex houses re: & arch and development activities $\mathrm{c}$ & onducted by the Chemistry and Mat & erials Science Director & rate, Engineering, We & apons Engine & ering, and Safeg & ards and Securi & ty Materials Mana & gement Division. & - & & & & & & & & \\
\hline Managem & toversight for $B$ & ilding 231 is provided by the Engii & Reering Directorate through the Engi & neering Sciences Divis & & & & & & & & & & & & & & & \\
\hline 231 & 1000 & FFE-5 & Metal casting & $\mathrm{U}-238$ & $2.6 E-07$ & $1.0 \mathrm{E}-06$ & 8.2 & 0.32 & 7.7 & HEPA & 0.01 & $2.66-15$ & 1167 & $E$ & $1.7 E-11$ & 671 & w & $6.8 \mathrm{E}-11$ & 2 \\
\hline & & & & $u-234$ & $\begin{array}{l}3.3 E-09 \\
2.4 E-08\end{array}$ & $\frac{1.0 \mathrm{C}-06}{1.0 \mathrm{E}-06}$ & & & & & & $2.4 \mathrm{E}-16$ & & & & & & & \\
\hline 231 & 1427 & Room Air & Wet grinding/lapping & u-238 & $3.1 \mathrm{E}-07$ & $1.0 E-06$ & $\mathrm{NA}$ & $\mathrm{NA}$ & $\mathrm{NA}$ & None & 1 & $3.1 \mathrm{E}-13$ & 1167 & $\mathrm{E}$ & $4.3 E-11$ & 671 & w & $3.6 \mathrm{E}-10$ & 2 \\
\hline & & & & $\frac{\mathrm{U}-235}{\mathrm{U}-234}$ & $\begin{array}{l}1.5 E-08 \\
3.3-07\end{array}$ & 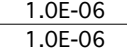 & & & & & 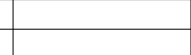 & $\frac{1.5 \mathrm{E}-14}{3.3-13}$ & & & & & & & \\
\hline 231 & 1600 & Room Air & Friction test on solid & u-238 & $1.5 \mathrm{E}-03$ & $1.0 \mathrm{E}-06$ & $\mathrm{NA}$ & $\mathrm{NA}$ & $\mathrm{NA}$ & None & 1 & $1.5 \mathrm{E}-09$ & 1167 & $E$ & $1.11 E-07$ & 671 & w & $8.88-07$ & 2 \\
\hline & & & depleted uranium bars & $\frac{\mathrm{U}-235}{\mathrm{U}-234}$ & $\frac{1.94-22}{1.4-01}$ & $\begin{array}{l}1.0 \mathrm{O}-06 \\
100-06\end{array}$ & & & & & & $\frac{1.9 \mathrm{E}-08}{1.4-07}$ & & & & & & & \\
\hline 231 & 1640 & Room Air & Mechanical test: quasistatic & $0-238$ & $5.9 \mathrm{E}-09$ & $100-06$ & NA & NA & NA & None & 1 & $59 \mathrm{gE}-15$ & 1167 & $E$ & $4, E_{1-13}>2$ & 671 & $w$ & $3,4 E-12$ & $2+2+3$ \\
\hline & & & compression & $\frac{U-235}{U-234}$ & $\begin{array}{l}7.6 E-11 \\
5.5-10 \\
\end{array}$ & $\begin{array}{l}1.0 \mathrm{OE}-06 \\
100-06\end{array}$ & & & & & & $\begin{array}{l}7.66-17 \\
55-16\end{array}$ & & & & & & & \\
\hline 231 & 1678 & Room Air & Mechanical test: con & $\frac{11-238}{2}>2>0$ & $68 E-09$ & $10=06-2>C$ & $N A$ & $N A$ & NA & None & 1 & $688^{6-15}>0$ & 1167 & $\mathrm{E}$ & 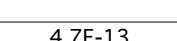 & 671 & w & $395-12$ & $=$ \\
\hline & & & Hopkinson bar (UGNb) & $u-235$ & $8.7 E-11$ & $1.0 \mathrm{E}-06$ & & & & & & $8.7 E-17$ & & 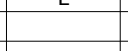 & 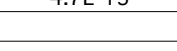 & & $w$ & (1) & \\
\hline & & & & U-234 & $6.3 E-10$ & 1.0E-06 & & & & & & $6.3 E-16$ & & & & & & & \\
\hline 231 & 1737 & FGBE-5 & Electron beam welding & $\mathrm{U}-238$ & $1.5 \mathrm{E}-06$ & $1.0 \mathrm{E}-06$ & 10.1 & 0.46 & 1.5 & HEPA & 0.01 & $1.5 \mathrm{E}-14$ & 1167 & $E$ & $1.0 E-12$ & 671 & w & $5.6 E-10$ & 2 \\
\hline & 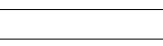 & & & $\mathrm{U}-234$ & $\begin{array}{l}1.96-00 \\
1.44-07\end{array}$ & $\begin{array}{l}1.0 \mathrm{CO}-\mathrm{E}-6 \\
.0 \mathrm{E}-06\end{array}$ & & 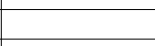 & - & & & $1.4 \mathrm{E}-15$ & & 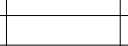 & & & & & \\
\hline & & & & U-238 & $8.1 E-11$ & $1.0 \mathrm{E}-03$ & & & & & & $8.1 \mathrm{E}-16$ & & - & & & & & 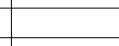 \\
\hline & & & & $\mathrm{U}-234$ & $7.5 E-12$ & $1.0 E-03$ & & & & & & $7.5 E-17$ & & & & & & & \\
\hline 231 & $1737 \mathrm{~A}$ & FHE-54 & Electron beam welding & U-238 & $1.5 \mathrm{E}-06$ & $1.0 \mathrm{E}-06$ & 10.1 & 0.46 & 1.5 & HEPA & 0.01 & $1.5 \mathrm{E}-14$ & 1167 & $\mathrm{E}$ & $1.0 E-12$ & 671 & w & $5.6 \mathrm{E}-10$ & 2 \\
\hline & & & & $\begin{array}{l}u-255 \\
U-234\end{array}$ & $\begin{array}{l}1.9 .4-08 \\
1.4 \mathrm{E}-07\end{array}$ & $\begin{array}{l}1.0 E-06 \\
1.0 E-06 \\
\end{array}$ & & & & & & $\begin{array}{l}1.9-9-16 \\
1.4 E-15\end{array}$ & & 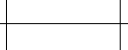 & & & & & \\
\hline & & & & U-238 & $8.1 \mathrm{E}-11$ & $1.0 \mathrm{E}-03$ & & & & & & $8.1 \mathrm{E}-16$ & & & & & & & \\
\hline & & & & $\begin{array}{l}U-253 \\
U-234\end{array}$ & 1.0E-12 & $\begin{array}{l}1.0 .0-0.3 \\
1.0 E-03\end{array}$ & & & & & & $\begin{array}{l}1.0-0-17 \\
7.5 E-17\end{array}$ & & & & & & & \\
\hline 231 & $1737 \mathrm{~B}$ & FHE-54 & Electron beam welding & $\mathrm{U}-238$ & $1.7 E-07$ & $1.0 \mathrm{E}-03$ & 10.1 & 0.46 & 11.5 & HEPA & 0.01 & $1.7 \mathrm{E}-12$ & 1167 & $E$ & $1.1 \mathrm{EE}-10$ & 671 & w & $6.0 \mathrm{0E}-08$ & 2 \\
\hline & & & & $\begin{array}{l}\mathrm{U}-235 \\
\mathrm{U}-234\end{array}$ & $\begin{array}{l}2.2 E-09 \\
1.6 E-08 \\
\end{array}$ & $\begin{array}{l}1.0 \mathrm{O}-03 \\
1.0 \mathrm{E}-03\end{array}$ & & & & & & $\begin{array}{l}2.2 E-14 \\
1.6-13 \\
\end{array}$ & & & & & & & \\
\hline 231 & 1739 & FGBE-5 & Storage & $\mathrm{U}-238$ & $1.5 E-07$ & $1.0 \mathrm{E}-06$ & 10.1 & 0.46 & 11.5 & HEPA & 0.01 & $1.5 E-15$ & 1167 & $\mathrm{E}$ & $1.0 \mathrm{E}-13$ & 671 & w & 5.4E-11 & 2 \\
\hline & & & & $\begin{array}{l}-2-235 \\
-234 \\
\end{array}$ & $\begin{array}{l}2.0 E-09 \\
1.4 E-08 \\
\end{array}$ & $\begin{array}{l}1.0 \mathrm{E}=06 \\
.0 E-06 \\
\end{array}$ & & & & & & $\begin{array}{l}2.0 E-11 \\
1.4 E-16 \\
\end{array}$ & & & & & +2 & 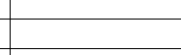 & 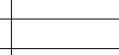 \\
\hline 231 & $1900 \mathrm{HB}$ & FGBE-7/8 $>$ & Storace & U-238 & $4.9 \mathrm{E}-06$ & $1.0 \mathrm{E}-06$ & 2.4 & 0.20 & 14.4 & None & 1 & $4.9 E-12,2>12$ & 1167 & $E$ & $3,3 \mathrm{E}-10$ & 671 & w & $2,2 E-09$ & 2 \\
\hline & & & & $\begin{array}{l}\mathrm{U}-235 \\
\mathrm{U}-234\end{array}$ & $\begin{array}{l}6.3 \mathrm{E}-08 \\
3.0-07\end{array}$ & $\begin{array}{l}1.0 \mathrm{O}-\mathrm{E}-6 \\
1.0 \mathrm{0}-06\end{array}$ & & & & & & $\begin{array}{l}6.3 E-14 \\
3.0 E-13\end{array}$ & & & & & & & \\
\hline 231 & $1944 \mathrm{~A}$ & Room Air & Mechanical testing & U-238 & $1.3 E-07$ & $1.0 \mathrm{EE}-06$ & $\mathrm{NA}$ & $\mathrm{NA}$ & $\mathrm{NA}$ & None & 1 & $1.3 E-13$ & 1167 & E & $9.2 E-12$ & 671 & w & $7.6 E-11$ & 2 \\
\hline & & & & $\begin{array}{l}\mathrm{U}-235 \\
\mathrm{U}-3234\end{array}$ & $\begin{array}{l}1.7 \mathrm{E}-09 \\
1.3 \mathrm{E}-08\end{array}$ & $\begin{array}{l}1.0 \mathrm{OE}-06 \\
1.0 \mathrm{E}-06\end{array}$ & & & & & & $\begin{array}{l}1.7-15-15 \\
1.3-14\end{array}$ & & & & & & & \\
\hline & & & & & & & & & & & & & & & & & & & \\
\hline
\end{tabular}


Attachment 1 - 2002 LLNL NESHAPs Annual Report Spreadsheet

\begin{tabular}{|c|c|c|c|c|c|c|c|c|c|c|c|c|c|c|c|c|c|c|c|}
\hline Building & Room/Area & Stack ID & Operation & Radionuclides & \begin{tabular}{|l|} 
Annual Inventory \\
\end{tabular} & Physical & Stack & Stack & & Control & \begin{tabular}{|l|} 
Control Device \\
Antomit
\end{tabular} & Estimated & $10 \mathrm{mrem} / \mathrm{ys}$ & 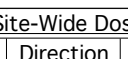 & $\begin{array}{l}\text { Se Requirement } \\
\text { ine }\end{array}$ & $0.1 \mathrm{mrem} /$ & $\begin{array}{l}y \text { Monitoring } \\
\text { Diritang }\end{array}$ & $\begin{array}{l}\text { Requirement } \\
\text { unabated }\end{array}$ & $\begin{array}{l}\text { Source } \\
\text { Catcory }\end{array}$ \\
\hline & & & & & $\begin{array}{l}\text { with Potential for } \\
\text { Release (Ci) }\end{array}$ & $\begin{array}{l}\text { State } \\
\text { Fantor }\end{array}$ & Height $(m)$ & $\begin{array}{l}\text { Diameter } \\
\text { (m) }\end{array}$ & 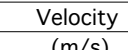 & $\begin{array}{l}\text { Device(s) } \\
\end{array}$ & \begin{tabular}{|l|} 
Abatement \\
\end{tabular} & & $\begin{array}{l}\text { Distance to } \\
\text { SSMPI(m) }\end{array}$ & $\begin{array}{l}\text { Direction } \\
\text { to sumet }\end{array}$ & EDE & $\begin{array}{l}\text { Distance } \\
\text { tomy(m) }\end{array}$ & $\begin{array}{l}\text { Direction } \\
\text { Dity }\end{array}$ & 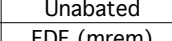 & \\
\hline 231 & 1945 & FHE-40 & Metal characterization & $\mathrm{U}-238$ & $\begin{array}{l}2.0 E-09 \\
2.05-10\end{array}$ & $1.0 \mathrm{E}-06$ & 10.7 & 0.36 & 3.8 & None & 1 & $2.0 E-15$ & 1167 & $\mathrm{E}$ & $1.3 \mathrm{E}-13$ & 671 & w & $5.4 \mathrm{E}-13$ & 2 \\
\hline & & & & 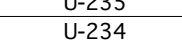 & $\frac{2.6 E-11}{1.9 E-10}$ & $\begin{array}{lll}1.100-00 \\
1.0-06\end{array}$ & & & & & & 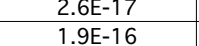 & & & & & & & \\
\hline 231 & $1945 \mathrm{~A}$ & Room Air & Metal characterization & u-238 & $2.0 E-12$ & $1.0 \mathrm{E}-06$ & $\mathrm{NA}$ & $\mathrm{NA}$ & $\mathrm{NA}$ & None & 1 & $2.0 E-18$ & 1167 & $\mathrm{E}$ & $1.4 E-16$ & 671 & w & $12 F-15$ & 2 \\
\hline & & & & $\begin{array}{l}u-235 \\
1-234\end{array}$ & $2.6 E-14$ & $1.0 \mathrm{E}-06$ & & & & & & $2.6 \mathrm{E}-20$ & & & & & & & \\
\hline & & & & & & & & & & & & & & & & & & & \\
\hline 231 & $1945 \mathrm{~B}$ & FHE-40 & Metal characterization & U-238 & 1.4-09 09 & $1.0 E-03$ & 10.0 & 0.41 & 4.6 & None & 1 & 1.4E-12 & 1167 & $E$ & $8.9 E-11$ & 671 & w & 3.5E-10 & 2 \\
\hline & & & & $\mathrm{u}-234$ & $1.3 \mathrm{E}-10$ & $1.0 \mathrm{E}-03$ & & & & & & $1.3 \mathrm{E}-13$ & & & & & & & \\
\hline 231 & $1945 \mathrm{C}$ & Room Air & Metal characterization & U-238 & $2.0 E-12$ & $1.0 E-06$ & $\mathrm{NA}$ & NA & $\mathrm{NA}$ & None & 1 & $2.0 \mathrm{E}-18$ & 1167 & $E$ & $1.4 E-16$ & 671 & w & $1.2 E-15$ & 2 \\
\hline & & & & $\begin{array}{l}\mathrm{U}-235 \\
\mathrm{U}-234 \\
\end{array}$ & $\frac{2.6-6-14}{1.9 E-13}$ & $\begin{array}{l}1.0 .0-06 \\
1.0 E-06\end{array}$ & & & & & & $\begin{array}{l}2.66-20 \\
1.9 E-19\end{array}$ & & & & & & & \\
\hline 231 & 1945D & Room Air & Metal polishing & U-238 & $2.0 E-09$ & $1.0 E-06$ & $\mathrm{NA}$ & $\mathrm{NA}$ & NA & None & 1 & $2.0 E-15$ & 1167 & $\mathrm{E}$ & $1.4 E-13$ & 671 & w & $1.2 E-12$ & 2 \\
\hline & & & & $\begin{array}{l}-0.235 \\
\mathrm{U}-234\end{array}$ & $\begin{array}{l}2.66-11 \\
1.9 E-10\end{array}$ & $\begin{array}{l}1.0 .0-06 \\
1.0 E-06\end{array}$ & & & & & & 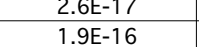 & & & & & & & \\
\hline 231 & 1945E & Room Air & Wet grinding/polishing & U-238 & $2.0 E-06$ & $1.0 \mathrm{E}-03$ & $\mathrm{NA}$ & $\mathrm{NA}$ & NA & None & 1 & $2.0 E-09$ & 1167 & $E$ & $1.4 E-07$ & 671 & w & $1.2 \mathrm{E}-06$ & 2 \\
\hline & & & & $\begin{array}{l}0.235 \\
U-234\end{array}$ & $\begin{array}{l}2.6-0-08 \\
1.9 E-07\end{array}$ & $\begin{array}{l}1.0 .0-03 \\
1.0 E-03 \\
\end{array}$ & & & & & & $\frac{2.6-11}{1.9 E-10}$ & & & & & & & \\
\hline ding 2: & 5 is part of the $c$ & nistry and Materials scie & orate. Operations in the faci & Clude examinat & $f$ material structu & e, and $\mathrm{s}$ & ubsurfac & on cutting, ion & nlanting, anc 5 & etallurgical studies. & & & & & & & & & \\
\hline lost of th & depleted uraniu & this building is used for cha & erization studies; some is used for & beam implantatio & experiments. & & & (a) & . & & & & & & & & & & \\
\hline 235 & 1122 & FHE-1A/1B, FHE2A/2B, & Surface analysis & U-234 & $1.5 \mathrm{E}-11$ & $1.0 E-06$ & 10.7 & 2.75 & 4.0 & None & 1 & $1.5 E-17$ & 1065 & ENE & $1.3 \mathrm{E}-14$ & 556 & SW & $1.3 E-14$ & 2 \\
\hline & & FGBE-IA/IB & & $\begin{array}{lll}U-233 \\
U-238\end{array}$ & $\frac{2.16-1}{1.6 E-10}$ & 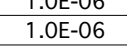 & & & & & & 年. $1.6 \mathrm{E}-18$ & & & & & & & \\
\hline FGross alp & $a$ and Gross beta & issions are continuously mon & ed at the stack. Monitoring data, ra & er than the invent & ry approach, are used & to determin & emissions. & & & & & & & & & & & & \\
\hline **Because & nonitoring takes & ce after HEPA filtration, an u & ated EDE cannot be determined (see & discussion in Secti & II, subsection "Stack & Monitoring $f$ & or Gross Alpha ar & Gross Beta Re & lation.") & & & & & & & & & & \\
\hline 235 & 1130 & FHE-1A/1B, FHE2A/2B, & Preparation of plutonium & Gross alpha & * & NA & 10.7 & 2.75 & 4.0 & Double HEPA & 0.0001 & $0.0 E+00$ & *t & ** & $0.0 E+00$ & ${ }^{* \star}$ & ** & $\star * *$ & 3 \\
\hline & & FGBE-1A/1B & samples for diamond anvil studies & Gross beta & & NA & & & & & & $0.0 E+00$ & & & & & & & \\
\hline 235 & 1131 & HDCH- 6,7 & Metallographic sample & U-234 & $1.1 \mathrm{E}-08$ & $1.0 \mathrm{E}-06$ & 10.7 & 2.75 & 4.0 & HEPA & 0.01 & $1.1 E-16$ & 1065 & ENE & $9.2 E-14$ & 556 & Sw & $9.66-12$ & 2 \\
\hline & & 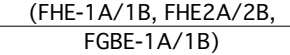 & preparation & $u-238$ & $\begin{array}{l}1.5 E-09 \\
1.2-07 \\
\end{array}$ & $\frac{1.00-06}{1.0 E-06}$ & & & & & & $1.22-15$ & & & & & & & \\
\hline 235 & 1133 & FHE-1A/1B, FHE2A/2B, & Microstructure examination & U-234 & $2.8 \mathrm{E}-09$ & $1.0 \mathrm{E}-06$ & 10.7 & 2.75 & 4.0 & None & 1 & & 1065 & ENE & $2.3 E-12$ & 556 & sw & $2.4 E-12$ & 2 \\
\hline & & $\mathrm{FGBE}-1 \mathrm{~A} / 1 \mathrm{~B}$ & & $\begin{array}{c}u-235 \\
1-238 \\
\end{array}$ & $\begin{array}{l}3.86-10 \\
3.050 .08 \\
\end{array}$ & $\begin{array}{l}1.0 \mathrm{O}-06 \\
10-06\end{array}$ & & & & & & $\begin{array}{l}3.8 E-16 \\
3.30-14\end{array}$ & & & & & & & \\
\hline 235 & 1235 & FHE-1A/1B, FHE2A/2B, & $x$-ray diffraction of & U-234 & 1.1E-09 & $1.0 \mathrm{DE}-06$ & 10.7 & 2.75 & 14.3 & None & 1 & 1.11E-15 & 1065 & ENE & $155-13$ & 556 & SW & $165-13$ & 2 \\
\hline & & $\mathrm{FGBE}-1 \mathrm{~A} / 1 \mathrm{~B}$ & uranium oxide ceramics & $u-235$ & $4.6 E-11$ & $1.0 \mathrm{E}-06$ & & 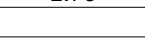 & & & & $4.6 E-17$ & & - & & & & & $L_{2}$ \\
\hline & & & & $0-238$ & $9.9 E-10$ & $1.0 E-06$ & & & & & & 9.9E-16 & & & & & & & \\
\hline Building 2. & I is administerece & the Chemistry and Material $S$ & nces Directorate for material proper & es research and te & ing, and for study of & soil bacteria. & & & & & & & & & & & & & \\
\hline 241 & 1616 & Room Air & Paritcle size analysis of powders & $u-238$ & $2.0 E-11$ & $1.0 \mathrm{E}-03$ & $\mathrm{NA}$ & $\mathrm{NA}$ & $\mathrm{NA}$ & None & 1 & $2.0 E-14$ & 1140 & E & $2.9 E-12$ & 697 & w & $2.2 E-11$ & 2 \\
\hline & & & & $\begin{array}{l}0-235 \\
-234 \\
\end{array}$ & $\begin{array}{l}9.3-1-13 \\
2.11-11 \\
\end{array}$ & $\begin{array}{l}1.0 .0-03 \\
1.0 E-03 \\
\end{array}$ & & & & & & 年.3E-16 $2.16-14$ & & & & & 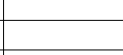 & 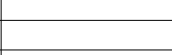 & \\
\hline 241 & 1678 & FHE-55 & Research and development & U-238 & $1.44-05$ & $1.0 E+00$ & 7.9 & 0.28 & 15.4 & HEPA & 0.01 & $1.4 \mathrm{E}-07$ & 1140 & $\mathrm{E}$ & $1.8 \mathrm{E}-05$ & 821 & SW & $4.46-03$ & 2 \\
\hline & & & 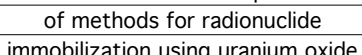 & $\frac{U-235}{U-234}$ & $\begin{array}{ll}6.7 \mathrm{E}-07 \\
15-0.05 \\
\end{array}$ & $\frac{1.0 E+00}{10.0+00}$ & & & & & & $\begin{array}{l}6.77-09 \\
1.55-07\end{array}$ & & & & & & & \\
\hline & & & 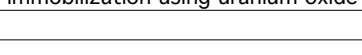 & $0-238$ & $9.46-07$ & $\frac{1.0 \mathrm{E}-03}{1.03}$ & & & & & & $\begin{array}{l}9.4 E-12 \\
9.4 E-12 \\
12\end{array}$ & & & & & & & \\
\hline & & & & $\begin{array}{r}\mathrm{U}-235 \\
\mathrm{U}-234 \\
\end{array}$ & $\begin{array}{l}4.4 E-08 \\
1.05-06 \\
\end{array}$ & $\begin{array}{l}1.0 \mathrm{O}-\mathrm{E}-3 \\
.0 \mathrm{E}-03 \\
\end{array}$ & & & & & & $\begin{array}{l}4.4 E-13 \\
1.0 E-11\end{array}$ & & & & & & & \\
\hline & & & & $\frac{U-238}{U-235}$ & $\begin{array}{l}1.9 E-07 \\
8.8 E-09\end{array}$ & $\frac{1.0 E-06}{100-06}$ & & & & & & $\begin{array}{l}1.9 E-15 \\
8.8 E-17\end{array}$ & & & & & & & \\
\hline & & & & $u-234$ & $2.0 E-07$ & $1.0 \mathrm{E}-06$ & & & & & & $2.0 E-15$ & & & & & & & \\
\hline 241 & 1838 & FGBE-10 & Pressing and sintering of & U-238 & $8.9 E-07$ & $1.0 E+00$ & 7.6 & 0.15 & 12.9 & HEPA & 0.01 & $8.9 E-09$ & 1140 & $E$ & $1.2 E-06$ & 697 & w & $5.9 E-04$ & 2 \\
\hline & & & & $\frac{u-235}{U-234}$ & $\begin{array}{l}4.2 E-08 \\
9.6 E-01\end{array}$ & $\begin{array}{l}1.0 \mathrm{E}+000 \\
1.0 \mathrm{E}+00\end{array}$ & & & & & & $\begin{array}{l}4.2 E-10 \\
9.6 E-03\end{array}$ & & & & & & & \\
\hline & & & & $\frac{\mathrm{U}-238}{\mathrm{U}-235}$ & $\begin{array}{l}2.0 E-10 \\
9.5-12 \\
2\end{array}-125$ & $\begin{array}{l}1.0 \mathrm{O}-\mathrm{E}-3 \\
1.0 \mathrm{O}-03\end{array}$ & & & & & & $\begin{array}{l}2.0 E-15 \\
9.5 E-17 \\
9\end{array}-170$ & & & & & & & \\
\hline & & & & u-234 & $2.2 E-10$ & $1.0 \mathrm{E}-03$ & & & & & & $2.2 E-15$ & & & & & & & \\
\hline & & & & $0-238$ & $9.96-15$ & $\begin{array}{l}1.0 \mathrm{E}-06 \\
100-06\end{array}$ & & & & & & $9.9 E-23$ & & & & & & & \\
\hline & & & & U-234 & $\frac{1.16-14}{1.14}$ & $\frac{1.0-06}{1.0-06}$ & & & & & & $\frac{1.1 E-22}{1.22}$ & & & & & & & \\
\hline
\end{tabular}


Attachment 1 - 2002 LLNL NESHAPs Annual Report Spreadsheet

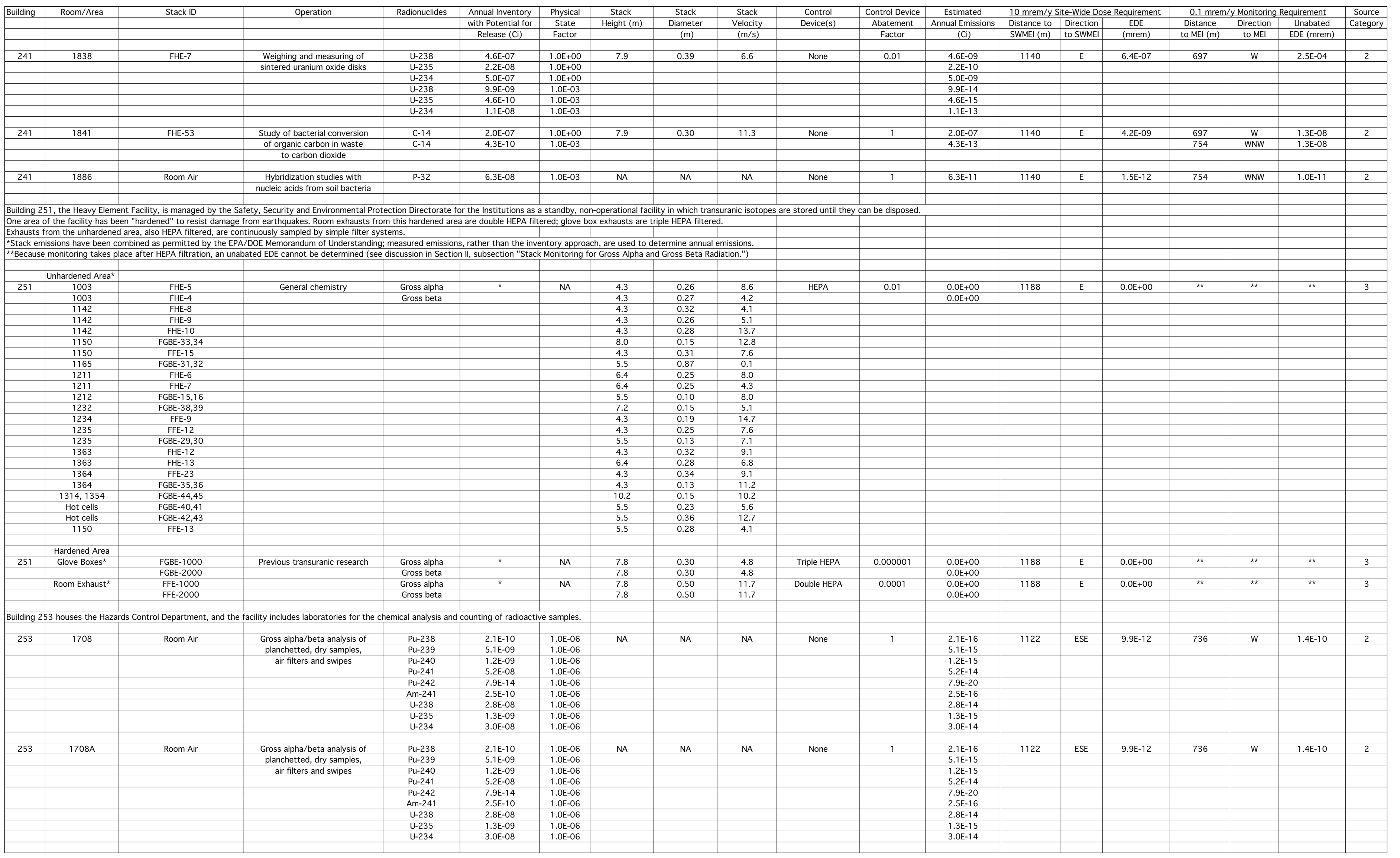


Attachment 1 - 2002 LLNL NESHAPs Annual Report Spreadsheet

\begin{tabular}{|c|c|c|c|c|c|c|c|c|c|c|c|c|c|c|c|c|c|c|c|}
\hline Building & Room/Area & Stack ID & Operation & Radionuclides & \begin{tabular}{|l|} 
Annual Inventory \\
with Potential for \\
\end{tabular} & \begin{tabular}{|l|} 
Physical \\
State
\end{tabular} & \begin{tabular}{l}
\multicolumn{1}{c}{ Stack } \\
Height $(m)$ \\
\end{tabular} & $\begin{array}{l}\text { Stack } \\
\text { Diameter }\end{array}$ & $\begin{array}{l}\text { Stack } \\
\text { Velocity }\end{array}$ & $\begin{array}{l}\text { Control } \\
\text { Device(s) }\end{array}$ & $\frac{\text { Control Device }}{\text { Abatement }}$ & $\begin{array}{c}\text { Estimated } \\
\text { Annual Emissions }\end{array}$ & $\frac{10 \mathrm{mrem} / \mathrm{ys}}{\text { Distance to }}$ & $\begin{array}{l}\text { ite-Wide Dos } \\
\text { Direction }\end{array}$ & $\frac{e \text { Requirement }}{\text { EDE }}$ & $\begin{array}{l}0.1 \mathrm{mrem} / \\
\text { Distace }\end{array}$ & $\begin{array}{l}\text { YMonitoring } \\
\text { Direction }\end{array}$ & $\begin{array}{l}\text { equirement } \\
\text { Unabated }\end{array}$ & $\begin{array}{l}\text { Source } \\
\text { Category }\end{array}$ \\
\hline & & & & & & & & & $(\mathrm{m} / \mathrm{s})$ & & & & & & & & & & \\
\hline 253 & 1708B & Room Air & & $\begin{array}{l}\text { Pu-238 } \\
P=20\end{array}$ & $2.1 \mathrm{E}-10$ & $1.0 \mathrm{E}-06$ & NA & $\mathrm{NA}$ & NA & None & 1 & $2.1 \mathrm{E}-16$ & 1122 & ESE & $9.9 \mathrm{E}-12$ & 736 & w & 1.4E-10 & 2 \\
\hline & & & & Putse & $\begin{array}{l}5.1-1 E-09 \\
1.2 E-09\end{array}-10$ & 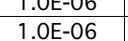 & & & & & & 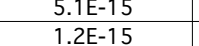 & & & & & & & \\
\hline & & & & Pu-241 & $5.22=-08$ & $1.0 \mathrm{E}-06$ & & 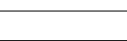 & 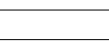 & & & $5.22-14$ & & & & & & & \\
\hline 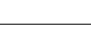 & & & & $\begin{array}{c}\text { Pu-242 } \\
A m-241\end{array}$ & $\begin{array}{l}7.9 E-14 \\
25-15\end{array}$ & $\begin{array}{l}1.0 \mathrm{E}-06 \\
100-06\end{array}$ & - & - & - & & & $\begin{array}{l}7.96-20 \\
255-26\end{array}$ & & & & & & & \\
\hline & & & & U-238 & $\begin{array}{l}2.5 \mathrm{E}-\mathrm{-}-0 \\
2.8 \mathrm{E}\end{array}$ & $\begin{array}{l}1.06-00 \\
1.06-06\end{array}$ & - & & & & & $2.8 \mathrm{E}-14$ & & & & & & & \\
\hline & & & & $\frac{U-235}{U-234}$ & $\begin{array}{l}1.3 \mathrm{E}-09 \\
3.0 \mathrm{E}-08\end{array}$ & $\begin{array}{l}1.0 E-06 \\
1.0 E-06\end{array}$ & & & & & & $\begin{array}{l}1.3 \mathrm{E}-15 \\
3.0 \mathrm{E}-14 \\
\mathrm{n}\end{array}$ & & & & & & & \\
\hline 253 & 1732 & FHE-21 & Flaming gross alpha/beta planchets & Pu-239 & $1.3 \mathrm{E}-13$ & $1.0 E+00$ & 6.4 & 0.30 & 13.2 & None & 1 & $1.3 \mathrm{E}-13$ & 1122 & ESE & $2.1 E-11$ & 736 & w & $1.4 \mathrm{E}-10$ & 2 \\
\hline & & & & $\begin{array}{l}\text { Gross alanha } \\
\text { Gross beta }\end{array}$ & 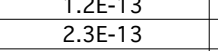 & $\begin{array}{l}\frac{1.0 E+00}{1.0 E+00} \\
\end{array}$ & & & & & & $\begin{array}{l}1.2 E-13 \\
2.3 E-13 \\
\end{array}$ & & & & & WNW & & \\
\hline & & & & $\mathrm{H}-3$ & $1.1 E-12$ & $1.0 \mathrm{E}+00$ & & & & & & $1.1 \mathrm{E}-12$ & & & & & & & \\
\hline 253 & 1734 & Room Air & Distillation of environmental & $\mathrm{H}-3$ & $6.7 \mathrm{E}-10$ & $1.0 E+00$ & NA & NA & NA & None & 1 & $6.7 \mathrm{E}-10$ & 1122 & ESE & $5.66-12$ & 736 & w & $7.8 E-11$ & 2 \\
\hline & & & samples & $\begin{array}{l}\text { Gross alpha } \\
\text { Gross beta }\end{array}$ & $5.4 E-14$ & $\frac{1.0 E+00}{1.0 E+00}$ & & & & & & 5.4E-14 & & & & & & & \\
\hline 253 & 1734 & FGBE-1,2 & Sieve soil samples & Gross alpha & $2.7 E-10$ & $1.0 \mathrm{E}-06$ & 6.1 & 0.10 & 23.6 & HEPA & 0.01 & $2.7 E-18$ & 1122 & ESE & $2.5 E-16$ & 736 & w & 2.4E-13 & 2 \\
\hline & & & & Gross beta & $4.6 E-10$ & $1.0 \mathrm{E}-06$ & & & & & & $4.6 E-18$ & & & & & & & -5 \\
\hline 253 & 1734 & FHE-13 & Samples and standards plating & Gross alpha & $1.7 E-11$ & $1.0 E+00$ & 10.4 & 0.30 & 12.3 & None & 1 & $1.7 \mathrm{E}-11$ & 1122 & ESE & $9.2 E-11$ & 798 & WNW & $4.6 E-10$ & 2 \\
\hline & & & & $\begin{array}{l}\text { Gross beta } \\
\mathrm{H}-3\end{array}$ & $\begin{array}{l}2.2 E-12 \\
1.2 E-11\end{array}$ & $\begin{array}{l}\frac{1.0 E+00}{1.0 E+00} \\
1\end{array}$ & & 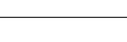 & & & & $\frac{2.2 E-12}{1.2 E-11}$ & & & & & & & \\
\hline & & & & Sr-90/Y-90 & $\frac{1.7 E-12}{7.8512}$ & $1.0 E+00$ & & & & & & $\frac{1.7 E-12}{7.85 .12}$ & & & & & & & \\
\hline 253 & 1724 & 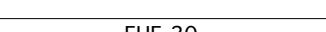 & Oulity control sample & Pww-239 & $255-12$ & $10002+4$ & 109 & 030 & 122 & Nom & 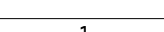 & 25015 & 1122 & & & & & & \\
\hline & 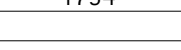 & 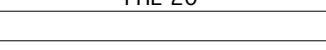 & aliquoting & Sr $r Y-90$ & $2.2 \mathrm{E}-12$ & $1.0 E-03$ & 10.7 & 0.000 & 2.0 & Noric & 1 & $2.2 E-15$ & 12 & sur & 1.0015 & 100 & 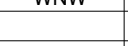 & . & 2 \\
\hline & & & & $\mathrm{H}-3$ & $1.1 \mathrm{E}-10$ & $1.0 \mathrm{E}-03$ & & & & & & $1.11 E-13$ & & & & & & & \\
\hline 253 & 1734 & FHE-11 & Acid digestion for & $\mathrm{H}-3$ & $6.8 \mathrm{E}-09$ & $1.0 E+00$ & 10.4 & 0.30 & 12.3 & None & 1 & $6.8 \mathrm{E}-09$ & 1122 & ESE & $2.8 \mathrm{E}-09$ & 798 & WNw & 1.4E-08 & 2 \\
\hline & & & sample analysis & Gross alaha & $\begin{array}{l}3.4-11 \\
2.2 E-10\end{array}$ & $\begin{array}{l}\frac{1.0 E+00}{1.0 E+00} \\
1.00\end{array}$ & & & & & & $\begin{array}{l}3.4 E-11 \\
2.2 E-10\end{array}$ & & & & 736 & w & 1.4E-08 & \\
\hline & & & & $\begin{array}{l}\text { SrlY-90 } \\
\text { Pu-239 }\end{array}$ & $2.8 E-12$ & $\frac{1.0 E+00}{1.0 E+00}$ & & & & & & $\begin{array}{l}2.8 E-12 \\
3.1 E-12\end{array}$ & & & & & & & \\
\hline 253 & 1910 & FHE-22 & Preparations of calibration & $\mathrm{H}-3$ & $3.0 \mathrm{E}-11$ & $1.0 \mathrm{E}-03$ & 7.0 & 0.20 & 5.2. & None & 1 & $3.0 E-14$ & 1122 & ESE & $1.8 E-15$ & 736 & w & $2.1 E-14$ & 2 \\
\hline & & & standards & $c-14$ & $1.5 E-11$ & $1.0 \mathrm{E}-03$ & & & & & & $1.5 E-14$ & & & & & & & \\
\hline & & & & & & & & & & & & & & & & & & & \\
\hline 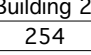 & $\begin{array}{l}4 \text { is run by Hazard } \\
108\end{array}$ & $\begin{array}{l}\text { Control for the purpose of cor } \\
\text { FHE-1000 }\end{array}$ & Ucting biabssays and providing analyti & al sercices. & $1.3 E-17$ & $1.0 \mathrm{E}-03$ & 8.2 & 1.07 & 5.3 & None & 1 & 1.3E-20 & 1038 & ESE & $3.7 E^{2}-17$ & 1070 & NNE & 1.4E-16 & 2 \\
\hline & & & radionuclides & $\begin{array}{l}\text { Put-242 } \\
\text { Pu-239 }\end{array}$ & 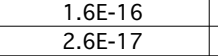 & 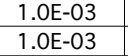 & & & 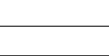 & & & 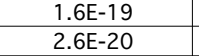 & & & & 849 & 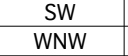 & $\frac{1.4 E-16}{1.4 E-16}$ & \\
\hline & & & & $\begin{array}{cc}H-3 \\
S-2\end{array}$ & $\begin{array}{l}1.4 E-14 \\
3.5114 \\
3.514\end{array}$ & 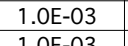 & & & & & & $\begin{array}{l}1.4 E-17 \\
3.5-17 \\
157\end{array}$ & & & & & & & \\
\hline & & & & 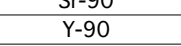 & $\begin{array}{ll}3.1 E-14 \\
3.1 E-14\end{array}$ & $\begin{array}{l}1.0 E-03 \\
1.0 E-03 \\
\end{array}$ & & & & & & $\begin{array}{l}3.1 E-17 \\
3.1 E-17\end{array}$ & & & & & & & \\
\hline 254 & 109 & FHE-1000 & Analysis of urine for & Am-243 & $1.3 E-17$ & $1.0 E-03$ & 8.2 & 1.07 & 5.3 & None & 1 & $1.3 \mathrm{E}-20$ & 1038 & ESE & $1.5 E-18$ & 1070 & NNE & $5.9 E-18$ & 2 \\
\hline & & & & & & & & & & & & & & & & & & & \\
\hline 254 & 110 & FHE-1000 & Analysis of urine for & Am-241 & $8.2 E-19$ & $1.0 \mathrm{E}-03$ & 8.2 & 1.07 & 5.3 & None & 1 & $8.2 E-22$ & 1038 & ESE & $1.3 \mathrm{E}-11$ & 1070 & NNE & $5.0 \mathrm{E}-11$ & 2 \\
\hline & & & radionuclides & Am-2343 & $\frac{2.3-17}{8.7-18}$ & $\begin{array}{l}1.0 E-03 \\
0=03\end{array}$ & & & & & & $\begin{array}{l}2.3-202 \\
872-2.1\end{array}$ & & & & & & & \\
\hline & & & & $\mathrm{Np}-237$ & 1.1.E-15 & $1.0 \mathrm{E}-03$ & & & & & & $1.1 E-18$ & & & & & & & \\
\hline & & & & Th-230 & $8.9 E-17$ & $\frac{1.0 E-03}{100.03}$ & & & & & & $8.9 E-20$ & & & & & & & \\
\hline & & & & Unt & (2) & 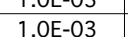 & & & & & & 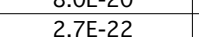 & & & & & & & \\
\hline & & & & $0-234$ & $2.6-18$ & $1.0 \mathrm{E}-03$ & & & & & & $2.6 \mathrm{E}-21$ & & & & & & & \\
\hline & & & & $\frac{U-235}{U-236}$ & $2.7 E-19$ & $\begin{array}{l}1.0 E-03 \\
1.0 E-03\end{array}$ & & & & & & $\begin{array}{l}2.7-2-22 \\
833-20\end{array}$ & & & & & & & \\
\hline & & & & u-238 & $6.3-21$ & $1.0 E-03$ & & & & & & $\frac{6.3-24}{6.32-24}$ & & & & & & & \\
\hline & & & & Mixed gamma & 4.5E-12 & $1.0 \mathrm{E}-03$ & & & & & & 4.5E-15 & & & & & & & \\
\hline & & & & $\begin{array}{cc}C f-249 \\
u-232\end{array}$ & 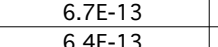 & $\begin{array}{l}1.0 E-03 \\
1.0 E-03 \\
\end{array}$ & & & & & & $\begin{array}{l}6.7 E-16 \\
644-16 \\
6\end{array}$ & & & & & & & \\
\hline & & & & Po-209 & 7.1E-14 & $1.0 \mathrm{E}-03$ & & & & & & $7.1 E-17$ & & & & & & & \\
\hline & & & & $\begin{array}{l}\text { Pu-242 } \\
\text { Pu-239 }\end{array}$ & $\frac{1.4 E-13}{2.2 E-14}$ & $\begin{array}{l}1.0 E-03 \\
1.0 E-03 \\
\end{array}$ & & & & & & 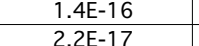 & & & & & & & \\
\hline & & & & $p-32$ & 7..0E-12 12 & $1.0 E-03$ & & & & & & (7.0E-15 & & & & & & & \\
\hline & & & & $\begin{array}{c}S-35 \\
c-14\end{array}$ & $\begin{array}{l}3.2 E-12 \\
56-12\end{array}$ & $\begin{array}{l}1.0 E-03 \\
10 E-03\end{array}$ & & & & & & $\begin{array}{l}3.2-15 \\
3.0-15\end{array}$ & & & & & & & \\
\hline & & & & $\frac{P-33}{P}$ & $\frac{-1.1 \mathrm{E}-12}{1.12}$ & 1.0E-03 & & & & & & 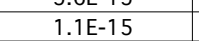 & & & & & & & \\
\hline
\end{tabular}


Attachment 1 - 2002 LLNL NESHAPs Annual Report Spreadsheet

\begin{tabular}{|c|c|c|c|c|c|c|c|c|c|c|c|c|c|c|c|c|c|c|c|}
\hline Building & Room/Area & Stack ID & Operation & Radionuclides & \begin{tabular}{|l|} 
Annual Inventory \\
wivth Potentialf for
\end{tabular} & $\begin{array}{l}\text { Physical } \\
\text { Stata }\end{array}$ & $\begin{array}{l}\text { Stack } \\
\text { Height }(m) \\
\end{array}$ & $\begin{array}{l}\text { Stack } \\
\text { Dismeter }\end{array}$ & $\begin{array}{c}\text { Stack } \\
\text { Velocity }\end{array}$ & $\begin{array}{ll}\text { Control } \\
\end{array}$ & Control Device & Estimated & $\frac{10 \mathrm{mrem} / \mathrm{y} \mathrm{s}}{1}$ & $\begin{array}{ll}\text { tite-Wide Dos } \\
\text { ithiotion }\end{array}$ & $\begin{array}{l}\text { Se Requirement } \\
\text { En }\end{array}$ & $0.1 \mathrm{mrem}$ & y Monitoring & Requirement & Source \\
\hline & & & & & $\begin{array}{l}\text { with Potential for } \\
\text { Release (Ci) }\end{array}$ & $\begin{array}{l}\text { State } \\
\text { Factor }\end{array}$ & & $\begin{array}{l}\text { Diameter } \\
(m)\end{array}$ & $\begin{array}{l}\text { Velocity } \\
(m / s)\end{array}$ & & $\begin{array}{l}\text { Abatement } \\
\text { Factor }\end{array}$ & $\begin{array}{l}\text { Annual Emissions } \\
\text { (Ci) }\end{array}$ & $\begin{array}{l}\text { Distance to } \\
\text { SWMEI (m) }\end{array}$ & $\begin{array}{l}\text { Direction } \\
\text { to SWMEI }\end{array}$ & $\frac{\mathrm{EDE}}{(\mathrm{mrem})}$ & $\begin{array}{l}\text { Distance } \\
\text { to MEI (m) }\end{array}$ & $\begin{array}{c}\text { Direction } \\
\text { to MEI }\end{array}$ & $\begin{array}{l}\text { Unabated } \\
\text { EDE (mrem) }\end{array}$ & Category \\
\hline 254 & 110 & (continued) & & $\frac{1-125}{S-9600}$ & $\begin{array}{l}9.0 E-13 \\
550-14\end{array}$ & $\begin{array}{l}1.0 \mathrm{OE}-03 \\
1.00-03\end{array}$ & & & & & & $\begin{array}{l}9.0 \mathrm{E}-16 \\
5.0 \mathrm{E}-17\end{array}$ & & & & & & & \\
\hline & & & & $Y-90$ & $5.0 E-14$ & $1.0 \mathrm{E}-03$ & & & & & & $5.0 \mathrm{E}-17$ & & & & & & & \\
\hline & & & & $\begin{array}{l}\text { Npp-237 } \\
\text { No-239 }\end{array}$ & $\begin{array}{l}1.11 \mathrm{I}-10 \\
6.2 \mathrm{E}-10 \\
\end{array}$ & $\begin{array}{l}1.0 \mathrm{O}-03 \\
1.0 \mathrm{E}-03 \\
\end{array}$ & & & & & & $\frac{1.1 E-13}{6.2 E-13}$ & & & & & & & \\
\hline & & & & $\frac{C_{m}-242}{\mathrm{Th}-230}$ & $\frac{9.14-13}{9.46-12}$ & $\frac{1.0 \mathrm{O}-\mathrm{-}-3}{1.03}$ & & & & & & $\begin{array}{l}9.14-16 \\
9.4-15\end{array}$ & & & & & & & \\
\hline & & & & $\begin{array}{ll}\frac{c f-252}{u} \\
\mathrm{U}-233\end{array}$ & $\begin{array}{l}8.4-12 \\
2.2-16 \\
\end{array}$ & $\begin{array}{l}1.0 \mathrm{OE}-03 \\
10.03\end{array}$ & & & & & & $\begin{array}{l}8.4 E-15 \\
2.2-19 \\
\end{array}$ & & & & & & & \\
\hline & & & & $0-234$ & $8.2 E-15$ & $1.0 E-03$ & & & & & & $8.2 \mathrm{E}-18$ & & & & & & & \\
\hline & & & & $\frac{0-235}{4}$ & $\frac{2.3 E-16}{58-14}$ & $\begin{array}{l}1.0 E-03 \\
100-03\end{array}$ & & & & & & $\begin{array}{l}2.3 E-19 \\
5.85-17\end{array}$ & & & & & & & \\
\hline & & & & $\begin{array}{lll}0-238 \\
U-238\end{array}$ & 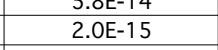 & 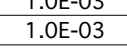 & & & & & & 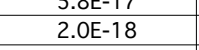 & & & & & & & \\
\hline 254 & 113 & FHE-1000 & Analysis of urine for & Pu-242 & $1.6 \mathrm{E}-16$ & $1.0 \mathrm{E}-03$ & 8.2 & 1.07 & 5.3 & None & 1 & $1.66-19$ & 1038 & ESE & $3.8 E-17$ & 1070 & NNE & $1.4 E-16$ & 2 \\
\hline & & & radionuclides & $\begin{array}{lll}P u-239 \\
H-3\end{array}$ & $2.6 E-17$ & $\begin{array}{l}1.0 \mathrm{OE}-03 \\
100-03\end{array}$ & & & & & & $\begin{array}{l}2.6 \mathrm{E}-20 \\
1 . \mathrm{E}-17\end{array}$ & & & & $\frac{1055}{877}$ & $\frac{S W}{W}$ & $\begin{array}{l}1.4 E-16 \\
1.4 E-16\end{array}$ & - \\
\hline & & & & $c-14$ & $1.4 E-14$ & $1.0 \mathrm{E}-03$ & & & & & & $1.4 \mathrm{E}-17$ & & & & 849 & WNW & 1.4E-16 & \\
\hline & & & & $\begin{array}{l}S r-90 \\
500\end{array}$ & 3.11-14 & $1.0 \mathrm{E}-03$ & & & & & & 3.1E-17 & & & & & & & \\
\hline & & & & Am-243 & $\frac{3.1 .1-14}{1.3 E-17}$ & $\begin{array}{l}1.0 \mathrm{E}=\mathrm{E} \\
.0 \mathrm{E}-03 \\
\end{array}$ & & & 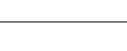 & & & $\begin{array}{l}3.1 .1-17 \\
1.3 E-20\end{array}$ & & & & & & & \\
\hline uilding 2 & 5 is operated by $H$ & azards Control and houses a radia & tion calibration and standards labora & tory. Many operation & Is involve the use of $\mathrm{s}$ & ealed source & & & & & & & & & & & & & \\
\hline 255 & 165 & FHE-4 & Analysis of urine for & $1-125$ & $2.3 \mathrm{E}-09$ & $1.0 E-03$ & 6.9 & 0.30 & 5.1 & None & 1 & $2.3 \mathrm{E}-12$ & 1056 & $\mathrm{E}$ & $6.1 E-12$ & 790 & w & $1.8 \mathrm{E}-11$ & 2 \\
\hline & & & & $\frac{1-131}{T h-230}$ & 1.2.7-099 & $\begin{array}{l}1.0 \mathrm{E}-\mathrm{C}-\mathrm{S} \\
.10 \mathrm{E}-03\end{array}$ & 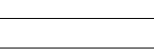 & 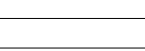 & 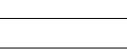 & & 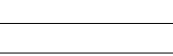 & $5.7 E-17$ & & & & & 列 & & 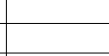 \\
\hline & & & & Th-232 & $\frac{1.0 E-16}{10.0-11}$ & $1.0 \mathrm{E}-03$ & & & & & & $1.0 E-19$ & & & & & & & \\
\hline & & & & U-238 & $1.3 \mathrm{E}-15$ & $1.0 E-03$ & & & 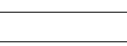 & & & $\begin{array}{l}1.0 \mathrm{U}-\mathrm{T}-18 \\
. \mathrm{E}-18\end{array}$ & & & & & & & 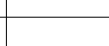 \\
\hline & & & & $\begin{array}{l}\frac{\mathrm{Np}-237}{\mathrm{Cm}-244} \\
\mathrm{c}-1\end{array}$ & $\begin{array}{l}5.7-7 E-14 \\
3.8-14\end{array}$ & $\frac{1.0 \mathrm{O}-\mathrm{E}-03}{1.03}$ & $E$ & 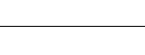 & - & & & $\begin{array}{l}5.78-17 \\
3.8-17\end{array}$ & & & & & & & - \\
\hline & & & & $\frac{A m-241}{A m-243}$ & $\begin{array}{l}3.8 E-15 \\
19-5-14\end{array}$ & $\begin{array}{l}1.0 \mathrm{OE}-03 \\
10-03\end{array}$ & 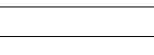 & & & & & $\begin{array}{l}3.8 \mathrm{E}-18 \\
9 \mathrm{GF}-17\end{array}$ & & & & & & & \\
\hline & - & & & $\begin{array}{l}\text { Am-243 } \\
\text { Put-239 }\end{array}$ & $\frac{1.9-14}{1.9 E-14}$ & $\frac{1.00-03}{1.03}$ & 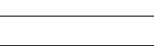 & & & & & $\frac{1.9-9-17}{1.9 E-17}$ & & & & & & & \\
\hline & & & & Pu-242 & $1.9 \mathrm{E}-15$ & $1.0 E-03$ & & & & & & $1.9 E-18$ & & & & & & & \\
\hline 255 & 180 & FHE-2 & Tritium gas monitor calibrations & $\mathrm{H}-3$ & $2.5 \mathrm{E}-02$ & $1.0 E+00$ & 8.1 & 0.31 & 5.2 & None & 1 & $2.5 \mathrm{E}-02$ & 1056 & $E$ & $9.9 E-06$ & 790 & w & $3.9 E-05$ & 2 \\
\hline Building 2. & 1 is part of the En & Ergy and Environment Directorate & Tracer work, dissolution studies an & d flow studies are cor & nducted in this buildir & & & & & & 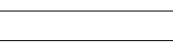 & 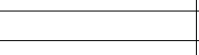 & & & & 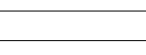 & & & \\
\hline 281 & 1174 & FHE-13 & Tracer work & $\mathrm{N}-63$ & $1.0 E-05$ & $1.0 E-03$ & 6.7 & 0.30 & 6.1 & None & 1 & $1.0 \mathrm{E}-08$ & 1332 & ESE & $2.4 \mathrm{E}-11$ & 579 & $\mathrm{NNE}$ & $3.1 E-10$ & 2 \\
\hline 281 & 1305 & Room air & Dissolution studies & $\mathrm{u}-238$ & $4.3 \mathrm{E}-09$ & $1.0 \mathrm{E}-03$ & $\mathrm{NA}$ & $\mathrm{NA}$ & $\mathrm{NA}$ & None & 1 & $4.3 \mathrm{E}-12$ & 1332 & ESE & $1.0 E-10$ & 753 & WNW & $1.8 \mathrm{E}-09$ & 2 \\
\hline 281 & 1307 & FHE-6 6 & Tracer work & No-237 & $2.5 E-12$ & $1.0 \mathrm{E}-03$ & 6.4 & 0.61 & 2.7 & None & 1 & $2.5 E-15$ & 1332 & ESE & $4.0 E-08$ & 753 & WNW & $5.66-07$ & 2 \\
\hline & & & & $\frac{U-238}{U-235}$ & $\begin{array}{l}4.10 E-14 \\
5.28 E-16\end{array}$ & $\frac{1.0 .0-03}{1.0-03}$ & & & & & & $\begin{array}{l}\frac{4.1 \mathrm{IE}-17}{5.3 E-19} \\
5\end{array}$ & & & & & & & \\
\hline & 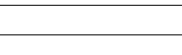 & & & $\begin{array}{l}\text { U-234 } \\
\text { Pu-239 }\end{array}$ & $\begin{array}{l}3.83 E-15 \\
3.3-07\end{array}$ & $\begin{array}{l}1.0 E-03 \\
100-03\end{array}$ & & & & & 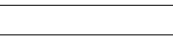 & $\begin{array}{l}3.8 \mathrm{E}-18 \\
3 . \mathrm{E}-10 \\
\end{array}$ & & & & & & & \\
\hline & & & & $\begin{array}{lll}\text { Pu-242 } \\
P u 223\end{array}$ & $2.12-11$ & $1.0 \mathrm{E}-03$ & & & & & & $\frac{1.5-14}{2.12-14}$ & & & & & & & \\
\hline & & & & Pu-244 & $\begin{array}{l}2.3 E-08 \\
1.6 E-09 \\
\end{array}$ & $\begin{array}{l}1.0 \mathrm{E}-03 \\
.0 \mathrm{E}-03 \\
\end{array}$ & & & & & & $\begin{array}{l}2.33-11 \\
1.6 E-12 \\
\end{array}$ & & & & & & & \\
\hline & & & & $\begin{array}{l}\mathrm{N}-63 \\
\mathrm{~N}-59 \\
\end{array}$ & $\begin{array}{l}2.0 E=-04 \\
7.0 E-08\end{array}$ & 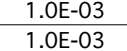 & & & & & & $\begin{array}{l}2.0 \mathrm{E}-07 \\
7.0 \mathrm{E}-11\end{array}$ & & & & & & & \\
\hline 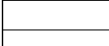 & 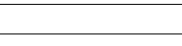 & & & TC-99 & $\begin{array}{l}1.06-07 \\
1.0-25\end{array}$ & $\frac{1.0-03}{1.00-03}$ & ${ }_{-}$ & 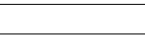 & 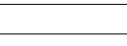 & & & $1.0 \mathrm{E}-10$ & & & & & & & \\
\hline & & & & $\frac{S-90}{C-2-41}$ & $\frac{1.0-0=5}{1.0-04}$ & $\frac{1.0 .0-03}{1.0 E-03}$ & & & & & & $\begin{array}{l}1.0 E-08 \\
1.0=-07\end{array}$ & & & & & & & \\
\hline- & 列 & & & Be-10 & 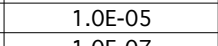 & $1.0 \mathrm{EE}-03$ & 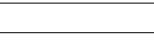 & & & & & $1.0 E-08$ & & & & & & & \\
\hline & & & & & & & & & & & & & & & & & & & \\
\hline 281 & 1311 & FHE-12 & Solution preparation & C-14 & $1.9 E-04$ & $1.0 \mathrm{EE}-03$ & 6.1 & 0.41 & 4.0 & None & 1 & $1.9 \mathrm{E}-07$ & 1332 & ESE & $4.0 E-09$ & 753 & WNW & $5.5 E-08$ & 2 \\
\hline & & & & $\mathrm{H}-3$ & $2.5 \mathrm{E}-05$ & $1.0 \mathrm{E}-03$ & & & & & & $2.5 E-08$ & & & & & & & \\
\hline 281 & 1323 & FHE-1 & Radioactivity migration studies & $\mathrm{Na}-22$ & $8.0 E-08$ & $1.0 \mathrm{E}-03$ & 6.7 & 0.30 & 6.1 & None & 1 & $8.0 \mathrm{E}-11$ & 1332 & ESE & $6.2 E-09$ & 579 & NNE & $8.3 E-08$ & 2 \\
\hline & & & & $\begin{array}{lll}u-238 \\
U-235\end{array}$ & $5.5 E-09$ & $\frac{1.0 E-0.5}{1.0 E-03}$ & & & & & & $\frac{1.25-10}{5.5 E-12}$ & & & & & & & \\
\hline & & & & U-234 & $1.3 E-07$ & $1.0 \mathrm{EE}-03$ & & & & & & $1.3 \mathrm{E}-10$ & & & & & & & \\
\hline Building 2. & 2 is administered & yy the Physics and Space Director & ate. Residual contamination exists in & the facility from past & toperations. & & & & & & & & & & & & & & \\
\hline 282 & 1000 & Room Air & Contamination & $\mathrm{H}-3$ & $4.0 \mathrm{E}-06$ & $1.0 \mathrm{E}-03$ & $\mathrm{NA}$ & $\mathrm{NA}$ & $\mathrm{NA}$ & None & 1 & 4.0E-09 & 1332 & ESE & $6.2 E-13$ & 753 & WNW & $1.1 \mathrm{E}-11$ & 2 \\
\hline & & & & & & & & & & & & & & & & & & & \\
\hline
\end{tabular}


Attachment 1 - 2002 LLNL NESHAPs Annual Report Spreadsheet

\begin{tabular}{|c|c|c|c|c|c|c|c|c|c|c|c|c|c|c|c|c|c|c|c|}
\hline Suilding & Room/Area & Stack ID & Operation & Radionuclides & \begin{tabular}{|l|} 
Annual Inventory \\
with Potontilffor
\end{tabular} & $\begin{array}{l}\text { Physical } \\
\text { Phical }\end{array}$ & Stack & $\begin{array}{l}\text { Stack } \\
\text { Dimmore }\end{array}$ & $\begin{array}{c}\text { Stack } \\
\text { Volocity }\end{array}$ & $\begin{array}{l}\text { Control } \\
\text { Devicalsis }\end{array}$ & \begin{tabular}{|l|} 
Control Device \\
Antomont \\
\end{tabular} & 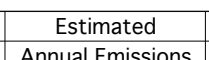 & $\frac{10 \mathrm{mrem} / \mathrm{ys}}{\text { Distanct }}$ & $\begin{array}{l}\text { Site-Wide Do } \\
\text { Diritction }\end{array}$ & $\begin{array}{l}\text { ose Requirement } \\
\text { IfDE }\end{array}$ & $\frac{0.1 \mathrm{mrem} / \mathrm{f}}{\text { Distace }}$ & $\frac{y \text { Monitoring }}{1 \text { Dirinction }}$ & $\begin{array}{l}g \text { Requirement } \\
\text { unabated }\end{array}$ & $\begin{array}{l}\text { Source } \\
\text { Category }\end{array}$ \\
\hline & & & & & \begin{tabular}{|l} 
with Potential for \\
Release (Ci)
\end{tabular} & $\begin{array}{l}\text { State } \\
\text { factor }\end{array}$ & Height $(\mathrm{m})$ & $\begin{array}{l}\text { Diameter } \\
(\mathrm{m})\end{array}$ & 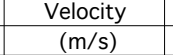 & Device(s) & $\begin{array}{l}\text { Abatement } \\
\text { Factor }\end{array}$ & $\begin{array}{l}\text { Annual Emissions } \\
\text { (Ci) }\end{array}$ & \begin{tabular}{|l|} 
Distance to \\
SWMEI (m)
\end{tabular} & $\begin{array}{l}\text { Diriction } \\
\text { to SWMEI }\end{array}$ & $\begin{array}{l}\text { EDE } \\
\text { (mrem) }\end{array}$ & $\begin{array}{l}\text { Distance } \\
\text { to MEI (m) }\end{array}$ & \begin{tabular}{|l} 
Direction \\
to MEI
\end{tabular} & $\begin{array}{l}\text { Unabated } \\
\text { EDE (mrem) }\end{array}$ & Category \\
\hline IIding 2 2 & is administered & iy the Environmental Programs Di & irectorate. Residual contamination ex & ists throughout the foc & acility from the past $\mathrm{c}$ & operation of a & rotating target $n$ & neutron source. & & & & & & & & & & & \\
\hline 292 & 1200,1202 & Room Air & Contamination & $\mathrm{H}-3$ & $1.8 \mathrm{E}+00$ & $1.0 \mathrm{E}-03$ & NA & NA & NA & None & 1 & $1.8 \mathrm{E}-03$ & 1380 & ESE & $3.9 \mathrm{E}-06$ & 655 & w & $9.2 \mathrm{E}-05$ & 2 \\
\hline & $\frac{1204}{1402,1402 \mathrm{~A}}$ & $\begin{array}{l}\text { Room Air } \\
\text { Room Air }\end{array}$ & $\begin{array}{l}\text { Contamination } \\
\text { Contamination }\end{array}$ & $\frac{\mathrm{H}-3}{\mathrm{H}-3}$ & $\frac{2.3 \mathrm{E}+01}{1.8+00}$ & $\begin{array}{l}1.0 E-03 \\
1.0 E-03\end{array}$ & $\frac{N A}{N A}$ & $\frac{N A}{N A}$ & $\frac{N A}{N A}$ & $\begin{array}{l}\text { None } \\
\text { None }\end{array}$ & $\frac{1}{1}$ & $\begin{array}{l}2.3 \mathrm{E}-02 \\
1.8 \mathrm{E}-03\end{array}$ & & & & & & & \\
\hline & $\begin{array}{l}140,11406 \\
1407\end{array}$ & & & & & & & & & & & & & & & & & & \\
\hline Building 2 & 98 is part of the $\mathrm{La}$ & Ser Fusion Program. Small amoun & its of tritium are used in this facility in & conjunction with fus & sion target research a & and developme & en & & & & & & & & & & & & 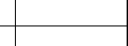 \\
\hline 298 & 160 & Room Air & D-T Tavering experiment & $4=3$ & 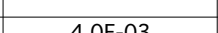 & $10=000$ & $N A$ & $N A$ & Na & None & 1 & 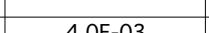 & 1200 & $\mathrm{Cr}_{\mathrm{C}}$ & $5750.07>20$ & 264 & & 20505 & \\
\hline & & 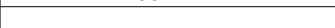 & (2) & & & & & 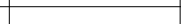 & 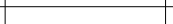 & 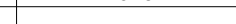 & & 0.000 & 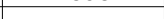 & & 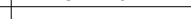 & - & & - 50 & 2 \\
\hline 298 & 189 & FHE-14 & Laser fusion target coating & U-238 & $1.3 \mathrm{E}-04$ & $1.0 \mathrm{E}-03$ & 6.4 & 0.63 & 15.1 & HEPA & 0.01 & $1.3 \mathrm{E}-09$ & 1398 & SE & $1.9 E-08$ & 344 & $\mathrm{NE}$ & $6.3 E-05$ & 2 \\
\hline 298 & Various & Room Air & $\begin{array}{l}\text { Laser fusion target research } \\
\text { and develooment }\end{array}$ & $\mathrm{H}-3$ & $1.0 \mathrm{E}-03$ & $1.0 E+00$ & NA & NA & $\mathrm{NA}$ & None & 1 & $1.0 \mathrm{E}-03$ & 1398 & SE & $1.4 \mathrm{E}-07$ & 264 & NNE & $7.66-06$ & 2 \\
\hline & & & and development & & & & & & & & & & & & & & & & \\
\hline Buildings & $\begin{array}{l}321,321 \mathrm{~A}, 321 \mathrm{~B}, \mathrm{z} \\
\text { jieces may be worke }\end{array}$ & $\begin{array}{l}\text { nd } 321 C \text { are the Material Fabricat } \\
\text { don in a single Iocation, or may }\end{array}$ & tion Shops and are part of the Mecharar & $\begin{array}{l}\text { hical Engininering Depa } \\
\text { In addition, depleted }\end{array}$ & $\begin{array}{l}\text { artment. Operations } \\
\text { urannium parts occasit }\end{array}$ & $\begin{array}{l}\text { Sint this comple } \\
\text { ionally undergs }\end{array}$ & $\begin{array}{l}\text { ex include enilling, } \\
\text { o heat treatment. }\end{array}$ & $\begin{array}{l}\text { 1, shaping and mac } \\
\mathrm{t} \text {. The amount of }\end{array}$ & $\begin{array}{l}\text { chining of fedplete } \\
\text { depleted uraniun }\end{array}$ & $\begin{array}{l}\text { tede dranium. } \\
\text { tum that is handled dep. }\end{array}$ & pends & & & & & & & & \\
\hline 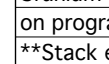 & $\begin{array}{l}m \text { matic demands an } \\
\text { missions have been }\end{array}$ & $\begin{array}{l}\text { d varies from month to month. } \\
\text { combined as perimted by the } E P\end{array}$ & 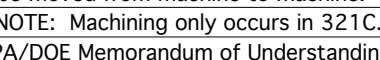 & D & & & & & & & & & & & & & & & \\
\hline $321 \mathrm{~A}$ & $1001 \mathrm{~A}$ & FHE-24 & Machining and manufacturing & U-234 $>3>0$ & $7.5 E-04$ & $1.0 E-06$ & 3.7 & 0.46 & 2.9 & $\begin{array}{l}\text { HEPA } \\
\end{array}$ & 0.01 & $7.5 E-12$ & 1032 & ENE & $1.10 \mathrm{E}-08$ & 326 & SW & $83 E-06$ & 2 \\
\hline & & & & $\frac{U-235}{U-238}$ & $\begin{array}{l}1.0 E-04 \\
8.1 E-03\end{array}$ & $\begin{array}{l}1.0 E-06 \\
10 E-06\end{array}$ & & & & & & $\begin{array}{l}1.0 E-12 \\
8.1 E-11\end{array}$ & & & & (2) & & - $>0$ & \\
\hline $321 \mathrm{C}$ & $234 \mathrm{~B}$ & FHE-13 & Lapping of DU metal & $u-238$ & $16 E-04$ & $100-06$ & 10.7 & 0.49 & 2.5 & None & 1 & $16 \mathrm{E}-10$ & 1032 & ENE & $180=-08$ & 326 & SW & $4,2 E-08$ & 2 \\
\hline & & & . the & $\frac{U-235}{U}-234$ & $\begin{array}{l}2.0 E-06 \\
9.4 E-06\end{array}$ & $\begin{array}{l}1.0 E-06 \\
1.0 E-06 \\
\end{array}$ & & & 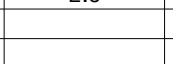 & & & $\begin{array}{l}2.0 E-12 \\
9.4-12 \\
\end{array}$ & ove & ENe & $1.00 \mathrm{v}=00$ & 我 & sw & 4.Cc=-00 & \\
\hline $321 \mathrm{C}$ & Varioust* $^{\text {th }}$ & FHE-9 & Machining and manufacturing & U-234 $>>3$ & 3.2E+00 $>2>-20$ & $1.0 E-06$ & 8.5 & 0.31 & 16.1 & HEPA & 0.01 & 3.2E-08 $>2>20$ & 1032 & ENE & 3.4E-08 & 252 & SW & $6,2=06$ & 2 \\
\hline & & FHE-11 & & $\mathrm{U}-235$ & $4.0 \mathrm{E}-02$ & $1.0 \mathrm{E}-06$ & 12.5 & 0.60 & 6.0 & HEPA & 0.01 & $\begin{array}{l}3.06-10 \\
4.06-10\end{array}$ & & & & 2036 & sw & $0.4 c=-00$ & 2 \\
\hline & & $\begin{array}{l}\text { FEL-15 } \\
\text { FEV-1000 }\end{array}$ & & U-238 & $3.0 \mathrm{E}-01$ & $1.0 \mathrm{E}-06$ & $\frac{11.2}{11.3}$ & 0.23 & $\frac{13.4}{6.5}$ & $\begin{array}{l}\text { HEPA } \\
\text { HEPA }\end{array}$ & 0.01 & $3.0 \mathrm{E}-09$ & & & & & & & \\
\hline Building 3 _ & 22 is operated by $\mathrm{t}$ & Te Mechanical Engineering Departt & ment. & & & & & & & & & & & & & & & & - \\
\hline & & & & & & & & & & & & & & & & & & & \\
\hline 326 & 109 & FHE-1 & $\begin{array}{l}\text { Cleaning and plating } \\
\text { leang }\end{array}$ & $\begin{array}{l}U-2334 \\
-1255\end{array}$ & 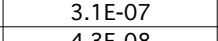 & $\begin{array}{l}1.0 E-06 \\
1.060\end{array}$ & 7.9 & 0.35 & 1.0 & None & 1 & 3.1E- -13 & 930 & ENE & $5.0 \mathrm{E}-10$ & 416 & sw & $1.8 \mathrm{E}-09$ & 2 \\
\hline & & & & $U-238$ & 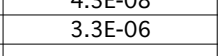 & 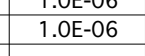 & & & & & & $\begin{aligned} 3.5 \mathrm{SE}-12 \\
.32\end{aligned}$ & & & & & & & \\
\hline Building 3 & 27 is operated by $t$ & le Mechanical Engineering Depart! & ment. & & & & & & & & & & & & & & & & 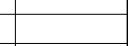 \\
\hline 327 & 1275 & Room Air & Non-destructive ultrasonic & U-234 & $1.3 \mathrm{E}-05$ & $1.0 \mathrm{E}-06$ & NA & NA & $\mathrm{NA}$ & None & 1 & $1.3 \mathrm{E}-11$ & 1018 & ENE & $1.9 \mathrm{E}-08$ & 425 & sw & $1.2 \mathrm{E}-07$ & 2 \\
\hline & & & & $\frac{U-235}{U-238}$ & $\begin{array}{l}1.9 E-06 \\
1.4 \mathrm{E}-04\end{array}$ & $\begin{array}{l}\frac{1.0 E-06}{1.0 E-06} \\
106\end{array}$ & & & & & & $\frac{1.9 E-12}{1.4-10}$ & & & & & & & \\
\hline Building : & 31 is & Nuclear Te & gies Directorate. The $b$ & the tritium research $\mathrm{f}$ & facility and associate & ed laboratories & & & & & & & & & & & & & \\
\hline $\begin{array}{l}{ }^{*}{ }^{*} \text { Tritium } \\
{ }^{*} \text { Stacks }\end{array}$ & $\begin{array}{l}\text { Tand HTO emissior } \\
\text { nasisjons have beon }\end{array}$ & 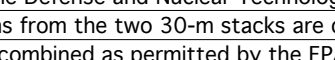 & 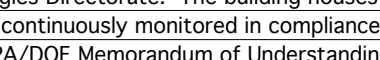 & with NESHAPs regula & $\begin{array}{l}\text { ations. Monitoring da } \\
\text { ala }\end{array}$ & ata, rather tha & in the inventory at & approach, are use & d to determine & emissions. & & & & & & & & & \\
\hline 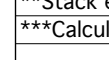 & 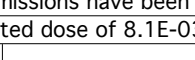 & 3 mrem includes modeling the HT & enissions as HTO, as directed by U.S & EPA, Region IX. The & dose from $\mathrm{HT}$ and $\mathrm{H}$ & HTO emissions & alculated approf & ppriately using ti & NEWTRIT mod & Iel is $5.6 \mathrm{E}-03$. See discu & cussion in Section & VIII, subsection "Mode & leling Dose from & m Tritium." & & & & & \\
\hline 331 & All*t & $\begin{array}{l}\text { Stack } 1 \\
\text { Stack } 2 \\
\end{array}$ & $\begin{array}{l}\text { Tritium research and development } \\
\text { Tropotaination frorte }\end{array}$ & $\begin{array}{ll}\mathrm{H}-3 \\
\mathrm{H}-3\end{array}$ & $*$ & $\begin{array}{l}1.0 E+00 \\
10 F+00\end{array}$ & $\begin{array}{l}30.0 \\
30.0 \\
3\end{array}-10$ & 1.22 & $\begin{array}{l}7.6 \\
105\end{array}$ & None & 1 & $2.5 E-02$ & 957 & ENE & $\begin{aligned} 8.1 E-03 \\
x+5.6-53\end{aligned}$ & 957 & ENE & $\begin{array}{l}8.1 E-03 \\
x+56-03\end{array}$ & 3 \\
\hline & & & Decontamination or parts & & & & & & & & & & & & & & & & \\
\hline 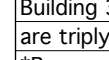 & $\begin{array}{l}32 \text { is operated by t } \\
\text { filtered by high effic }\end{array}$ & 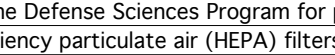 & $\begin{array}{l}\text { plutonium research. Exhaussts from } \\
\text { s. Exh }\end{array}$ & $\begin{array}{l}\text { love box operations a } \\
\text { continuous fitter sam! }\end{array}$ & $\begin{array}{l}\text { and the worksplace } \\
\text { ppling (PAM) and plut }\end{array}$ & tonium-specifi & ic, continuous rea & al-time monitors ( & (CAMs). & & & & & & & & & & \\
\hline $\begin{array}{l}\text { ¿Because } \\
\text { showno }\end{array}$ & $\begin{array}{l}\text { building plutonium i } \\
\text { letectable released }\end{array}$ & 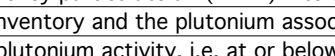 & 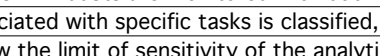 & $\begin{array}{l}\text { the standard NESHAF } \\
\text { cal analysis }\end{array}$ & Ps approach, based o & on inventory, c & cannot be utilized & d without classifyi & ing this report. & he air monitoring dat & ata for all emission $p$ & points & & & & & & & \\
\hline * & monitoring takes $p$ & lace after HEPA filtration, an unat & bated EDE cannot be determined (see & discussion in Section & nII, subsection "Stack & KMonitoring f & or Gross Alpha an & nd Gross Beta Rac & diation.") & & & & & & & & & & \\
\hline 332 & Increment 1 & FHE-1000/2000 & Plutonium research & Transuranics & * & NA & 8.8 & $0.8 \times 1.1$ & 17.3 & Double HEPA & 0.000001 & $0.0 E+00$ & 912 & ENE & $0.0 E+00$ & ** & ${ }^{* *}$ & ** & 3 \\
\hline & Rooms & & & & & & & & & & & & & & & & & & \\
\hline 332 & $\begin{array}{l}\text { Increment } 1 \\
\text { Glove boxes } \\
\end{array}$ & FGBE-1000/2000 & Plutonium research & Transuranics & * & $\mathrm{NA}$ & 11 & 0.3 & 6.9 & Triple HEPA & 0.000001 & $0.0 E+00$ & 912 & ENE & $0.0 E+00$ & ** & ** & ** & 3 \\
\hline 332 & $\begin{array}{l}\text { Downdraft } \\
\text {. }\end{array}$ & FHE- $4 / 5$ & Plutonium research & Transuranics & * & $\mathrm{NA}$ & 11 & 0.2 & 14.2 & Double HEPA & 0.0001 & $0.0 E+00$ & 912 & ENE & $0.0 E+00$ & ** & ** & $z_{* \star}$ & 3 \\
\hline 332 & Loft & $\mathrm{FE}-4$ & Plutonium research & Transuranics & * & $\mathrm{N} A$ & 11 & $0.6 \times 0.9$ & 4.6 & HEPA & 0.0 & 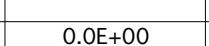 & 912 & ENE & $0.0 E+00$ & $* *$ & ${ }_{* *}^{* *}$ & $e^{* *}$ & 3 \\
\hline & & FE-5 & Plutonium research & Transuranics & * & NA & 11 & $0.6 \times 0.9$ & 4.6 & HEPA & 0.01 & $0.0 E+00$ & 912 & ENE & $0.0 E+00$ & ** & ** & ** & 3 \\
\hline 332 & Increment 1 & FGBE-3000/4000 & Plutonium research & Transuranics & * & NA & 11 & 0.3 & 2 & Triple HEPA & 0.000001 & $0.0 E+00$ & 912 & ENE & $0.0 E+00$ & ${ }^{* *}$ & $* \star$ & ${ }_{* *}^{*}$ & 3 \\
\hline & Giove b & & & & & & & & & & & & & & & & & & \\
\hline
\end{tabular}


Attachment 1 - 2002 LLNL NESHAPs Annual Report Spreadsheet

\begin{tabular}{|c|c|c|c|c|c|c|c|c|c|c|c|c|c|c|c|c|c|c|c|}
\hline Building & Room/Area & Stack ID & Operation & Radionuclides & \begin{tabular}{|l|} 
Annual Inventory \\
\end{tabular} & Physical & & Stack & Stack & Control & \begin{tabular}{|l|} 
Control Device \\
\end{tabular} & Estimated & $\frac{10 \operatorname{mrem} / \mathrm{SS}}{0.05}$ & 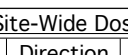 & Se Requirement & $\begin{array}{l}0.1 \mathrm{mrem} / \mathrm{s} \\
\text { D.sistance }\end{array}$ & Y Monitoring & $\begin{array}{l}\text { Requirement } \\
\text { Unnabated } \\
\end{array}$ & $\begin{array}{l}\text { Source } \\
\text { Catageory }\end{array}$ \\
\hline & & & & & \begin{tabular}{|l} 
with Potential for \\
Release (C)
\end{tabular} & $\begin{array}{l}\text { State } \\
\text { Factor }\end{array}$ & Height $(m)$ & $\begin{array}{c}\frac{D}{\text { Diameter }} \\
(\mathrm{m})\end{array}$ & $\begin{array}{l}\text { Velocity } \\
(\mathrm{m} / \mathrm{s})\end{array}$ & Device(s) & $\begin{array}{l}\text { Abatement } \\
\text { Factor }\end{array}$ & $\begin{array}{l}\text { Annual Emissions } \\
\text { (ii) }\end{array}$ & $\begin{array}{l}\text { Distance to } \\
\text { SSMEI (m) }\end{array}$ & $\begin{array}{l}\text { Direction } \\
\text { to SWMEI }\end{array}$ & $\frac{\text { EDE }}{(m r e m)}$ & $\begin{array}{l}\text { Distance } \\
\text { to MEI (m) }\end{array}$ & \begin{tabular}{|l|} 
Direction \\
to MEI \\
\end{tabular} & $\begin{array}{l}\text { Unabated } \\
\text { EDE (mrem) }\end{array}$ & \\
\hline 332 & Increment 3 & FFE-1000/2000 & Plutonium research & Transuranics & & $\mathrm{NA}$ & 10.1 & 0.9 & 12.2 & Room-Double HEPA & 0.000001 & $0.0 \mathrm{E}+00$ & 912 & ENE & $0.0 E+00$ & & & & 3 \\
\hline & $\begin{array}{l}\text { Room and } \\
\text { Glove boxes }\end{array}$ & FGBE-7000/8000 & & & & & & & & Glove Box-Triple HEPA & & & & & & & & & \\
\hline Building 34 & 1 is a Lasers Dire & orate facility. & & & & & & & & & & & & & & & & & 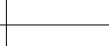 \\
\hline 341 & 1107 & Room Air & Blower decontamination & & & $100=0.03$ & NA & $N A$ & No & S & 1 & 源 & $872+2+3$ & $F$ & & & & & \\
\hline $3+1$ & Hior & Koom Alr & Bower ceecontamination & $0-235$ & 1.2E-11 & $1.00 \mathrm{E}-03$ & $\sqrt{N A}$ & $\sqrt{N A}$ & $N A$ & None & 1 & $\begin{array}{l}9.6 E-13 \\
1.2 E-14\end{array}$ & 872 & $E$ & $1.1 \mathrm{E}-10$ & 591 & $\begin{array}{l}\text { sw } \\
\text { ssw }\end{array}$ & $\frac{2.90 E E-10}{2.900-10}$ & 2 \\
\hline & & & & U-234 & $8.9 E-11$ & $1.00 \mathrm{E}-03$ & & & & & & $8.9 E-14$ & & & & & & & \\
\hline The researc & in complex for the & Biology and Biotechnology Rese: & ch Directorate includes Buildings 36 & $362,363,364,3$ & 5,366 and 377. Buil & ding 365 cor & ains & & & & & & & & & & & & \\
\hline $\begin{array}{l}\text { Small amou } \\
\text { at least tww }\end{array}$ & $\begin{array}{ll}\text { nts of tritium, car } \\
\text { nut }\end{array}$ & on- 14 and sulfur -35 used in & a research, and incorporated in anim & I carcasses stored & $\begin{array}{l}\text { ozen pending disposa } \\
\text { thyve heee removed }\end{array}$ & 1. The buildi & $\begin{array}{l}\text { air is filtered } \\
\text { als for cxaminat }\end{array}$ & ough & & & & & & & & & & & \\
\hline The radion & clide sources in $\mathrm{B}$ & lding 361 include tritium, carbo & 14 , phosphorous-32, phosphorous-3 & 3 , and sulfur $-35, m$ & stly incorporated as c & onstituent at & $\mathrm{ms}$ (tracers) in & ganic compou & & & & & & & & & & & \\
\hline 361 & 1020 & Room Air & DNA hybridization & P-32 & $1.3 \mathrm{E}-03$ & $1.0 E-03$ & NA & NA & NA & None & 1 & $1.3 \mathrm{E}-06$ & 918 & ESE & $2.1 E-08$ & 976 & w & 1.1E- -07 & 2 \\
\hline 361 & 1137 & Room Air & Protein hybridization & $\mathrm{P}-32$ & $4.7 E-02$ & $1.0 \mathrm{E}-03$ & NA & NA & NA & None & 1 & $4.7 E-05$ & 918 & ESE & $9.1 E-07$ & 976 & w & $4.6 E-06$ & 1 \\
\hline 361 & 1238 & Room Air & P-32 Labeling & P-32 & $8.0 \mathrm{E}-05$ & $1.0 \mathrm{E}-03$ & NA & $\mathrm{NA}$ & NA & None & 1 & $8.0 \mathrm{E}-08$ & 918 & ESE & $1.3 \mathrm{E}-09$ & 976 & w & $7.0 \mathrm{E}-09$ & 2 \\
\hline 361 & 1445 & Room Air & Radiolabeling of DNA substrates & $P-32$ & $2.2 E-04$ & $1.0 \mathrm{E}-03$ & $\mathrm{NA}$ & NA & $\mathrm{NA}$ & None & 1 & $2.2 E-07$ & 918 & ESE & $6.2 E-09$ & 976 & w & $3.4 E-08$ & 2 \\
\hline & & & & s-35 & 4. $1 E=-04$ & $1.0 E=03$ & & & & & & 4. $.1 E=0 r$ & & & & & & & \\
\hline 361 & 1446 & FHE-15 & Radiolabeling of DNA substrates & $\mathrm{P}-32$ & $5.5 E-04$ & $1.0 \mathrm{E}-03$ & 6.2 & 0.42 & 1.7 & None & 1 & $5.5 E-07$ & 918 & ESE & $8.7 \mathrm{E}-09$ & 976 & w & $4.7 E-08$ & 2 \\
\hline 361 & 1542 & FHE-12 & Hybridization and enzyme assay & P-32 & $2.0 \mathrm{E}-07$ & $1.0 E-03$ & 7.0 & 0.41 & 4.4 & None & 1 & $2.0 E-10$ & 918 & ESE & $2.9 E-12$ & 976 & w & $1.5 E-11$ & 2 \\
\hline 361 & 1546 & FHE-10 & DNA protein interaction studies & $\mathrm{P}-32$ & $3.2 E-04$ & $1.0 \mathrm{E}-03$ & 1.7 & 0.41 & 0.5 & None & 1 & $3.2 E-07$ & 918 & ESE & $4.9 E-09$ & 976 & w & $2.5 E-08$ & 2 \\
\hline 361 & 1664 & Room Air & DNA hybridization & P-32 & $6.4 \mathrm{E}-04$ & $1.0 \mathrm{E}-03$ & $\mathrm{NA}$ & NA & NA & None & 1 & $6.4 E-07$ & 918 & ESE & $1.0 E-08$ & 976 & w & $5.66-08$ & 2 \\
\hline 361 & $1664 \mathrm{~A}$ & Room Air & Labeling Olegios for & P-32 & $4.3 \mathrm{E}-04$ & $1.0 \mathrm{E}-03$ & $\mathrm{NA}$ & NA & NA & None & 1 & $4.3 E-07$ & 918 & ESE & $8.4 E-09$ & 976 & w & $4.2 E-08$ & 1 \\
\hline & & & high density fitier hybridzation & & & & & & & & & & & & & & & & \\
\hline 361 & 1742 & FHE-8 & DNA hybridization & $\mathrm{P}-32$ & $2.2 E-04$ & $1.0 \mathrm{E}-03$ & 7.0 & 0.41 & 4.4 & None & 1 & $2.2 E-07$ & 918 & ESE & $3.3 \mathrm{E}-09$ & 976 & w & $1.7 E-08$ & 2 \\
\hline 361 & 1846 & Room Air & Human genome research & $\mathrm{P}-32$ & $2.6 E-04$ & $1.0 E-03$ & NA & NA & NA & None & 1 & $2.66-07$ & 918 & ESE & $4.2 E-09$ & 976 & w & $2.3 E-08$ & 2 \\
\hline Building 36 & & & & & & & & & & & & & & & & & & & \\
\hline 362 & 105 & FHE-1000 & Compound purficication by HPLC & $\frac{H-3}{C-14}$ & $\begin{array}{l}\frac{1.0 E-04}{1.0-04} \\
-04\end{array}$ & $\begin{array}{l}1.0 E-03 \\
100-03\end{array}$ & 6.8 & 0.65 & 2.7 & None & 1 & $\begin{array}{l}1.0 \mathrm{E}-07 \\
10 \mathrm{O}-07 \\
\end{array}$ & 992 & ESE & $1.4 \mathrm{E}-09$ & 893 & w & $9.4 \mathrm{E}-09$ & 2 \\
\hline 362 & 106 & FHE-1000 & Characterization of & C-14 & $1.0 \mathrm{E}-08$ & 1.0E-03 $>30$ & 6.8 & 0.65 & 2.7 & None & 1 & $1.0 E-11$ & 992 & ESE & $6.7 \mathrm{E}-09$ & 893 & w & $4.66-08$ & 2 \\
\hline & & & metabolic pathways & $\mathrm{H}-3$ & $5.0 \mathrm{E}-04$ & $1.0 \mathrm{E}-03$ & & & & & & $5.0 \mathrm{E}-07$ & 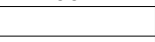 & & & & & & \\
\hline Building 36 & & & & & & & & & & & & & & & & & & & \\
\hline 363 & 1009 & FHE-2000 & Human urine sample project & $\begin{array}{l}\mathrm{H}-3 \\
\mathrm{C}-14 \\
-14-1\end{array}$ & $\begin{array}{l}1.0 \mathrm{E}-09 \\
1.0 \mathrm{E}-09\end{array}$ & $\begin{array}{l}1.0 .0-03 \\
1.0 E-03 \\
\end{array}$ & 1.7 & 0.41 & 0.4 & HEPA & 0.01 & $\frac{1.0 .0-14}{1.0 E-14}$ & 1000 & ESE & $1.5 E-16$ & 888 & w & $1.2 E-13$ & 2 \\
\hline 363 & 1010 & Room Air & HPLC analysis & $\mathrm{H}-3$ & $1.0 \mathrm{E}-09$ & $1.0 \mathrm{E}-03$ & $\mathrm{NA}$ & NA & NA & None & 1 & $1.0 E-12$ & 1000 & ESE & $1.6 \mathrm{E}-14$ & 888 & w & $1.3 E-13$ & 2 \\
\hline & & & & c-14 & $1.0 \mathrm{E}-09$ & $1.0 \mathrm{E}-03$ & & & & & & $1.0 \mathrm{E}-12$ & & & & & & & \\
\hline Building 3 & & & & & & & & & & & & & & & & & & & \\
\hline 364 & 1509 & FHE-02P & AMS sample preparation & $\begin{array}{ll}\mathrm{H}-3 \\
\mathrm{C}-14\end{array}$ & $\begin{array}{l}5.5 \mathrm{E}-14 \\
5.5 \mathrm{E}-07\end{array}$ & $\begin{array}{l}1.0 E+00 \\
1.0 .0+00\end{array}$ & 5.5 & 0.52 & 2.9 & None & 1 & $\begin{array}{l}5.5 E-14 \\
5.5 E-07\end{array}$ & 987 & ESE & $8.6 E-09$ & 912 & w & $6.8 \mathrm{E}-08$ & 2 \\
\hline 364 & $1509 \mathrm{~A}$ & Room Air & AMS sample preparation & $\mathrm{H}-3$ & $5.5 E-14$ & $1.0 E+00$ & NA & NA & NA & None & 1 & $5.5 E-14$ & 987 & ESE & $7.9 E-09$ & 912 & w & $5.66-08$ & 2 \\
\hline & & & & & & & & & & & & & & & & & & & \\
\hline 364 & 1519 & Room Air & DNA and protein extraction & $C-14$ & $5.06-06$ & $1.0 \mathrm{E}-03$ & $\mathrm{NA}$ & NA & $\mathrm{NA}$ & None & 1 & $5.0 E-09$ & 987 & ESE & $8.0 \mathrm{E}-11$ & 912 & w & $6.3 E-10$ & 2 \\
\hline & & & & & & & & & & & & & & & & & & 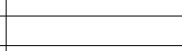 & \\
\hline$\frac{1}{365}$ & 104 & FHE-1000 & Equipment decontamination & C-14 & $1.0 \mathrm{E}-09$ & 1.0E-03 & 6.1 & 0.58 & 7.2 & $\begin{array}{l}\text { HEPA } \\
\end{array}$ & 0.01 & $1.0 E-14$ & 991 & ESE & $1.2 \mathrm{E}-16$ & 902 & w & $6.1 E-14$ & 2 \\
\hline & & & & $\mathrm{H}-3$ & $1.0 \mathrm{E}-09$ & $1.0 \mathrm{E}-03$ & & & & & & $1.00-14$ & & & & & & & \\
\hline 365 & 109 & FHE-5 & Animal housing & C-14 & $1.3 \mathrm{E}-05$ & $1.0 E-03$ & 1.7 & 0.41 & 0.6 & Double HEPA & 0.0001 & $1.3 E-12$ & 991 & ESE & $2.0 \mathrm{E}-14$ & 902 & w & $1.6 \mathrm{E}-09$ & 2 \\
\hline & & & & $\mathrm{H}-3$ & $5.0 \mathrm{E}-08$ & $1.0 E-03$ & & & & & & $5.0 E-15$ & & & & & & & \\
\hline Building 36 & & & & & & & & & & & & & & & & & & & \\
\hline 366 & 1111 & Room Air & Labeling & P-32 & $2.0 \mathrm{E}-03$ & $1.0 \mathrm{E}-03$ & $\mathrm{NA}$ & $\mathrm{NA}$ & $\mathrm{NA}$ & None & 1 & $2.0 \mathrm{E}-06$ & 925 & ESE & $3.2 E-08$ & 998 & w & $1.7 \mathrm{E}-07$ & 2 \\
\hline
\end{tabular}


Attachment 1 - 2002 LLNL NESHAPs Annual Report Spreadsheet

\begin{tabular}{|c|c|c|c|c|c|c|c|c|c|c|c|c|c|c|c|c|c|c|c|}
\hline uilding & Room/Area & Stack ID & Operation & Radionuclides & $\begin{array}{l}\text { Annual Inventory } \\
\text { With lotontij for }\end{array}$ & $\begin{array}{l}\text { Physical } \\
\text { Stato }\end{array}$ & 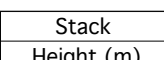 & $\begin{array}{l}\text { Stack } \\
\text { Dimenter }\end{array}$ & $\begin{array}{l}\text { Stack } \\
\text { Velcity }\end{array}$ & $\begin{array}{l}\text { Control } \\
\text { Devicalsis }\end{array}$ & \begin{tabular}{|l|} 
Control Device \\
Abratmit \\
\end{tabular} & $\begin{array}{l}\text { Estimated } \\
\text { snntal miscsin }\end{array}$ & $\frac{10 \mathrm{mrem} / \mathrm{y} \mathrm{Si}}{\text { Distanct }}$ & $\begin{array}{l}\text { tite-Wide Dos } \\
\text { Direction } 1\end{array}$ & & $\frac{0.1 \mathrm{mrem} / \mathrm{A}}{\text { Distace }}$ & $\frac{\mid y \text { Monitoring F }}{\text { Dinction }}$ & 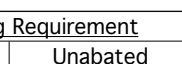 & $\begin{array}{l}\text { Source } \\
\text { Category }\end{array}$ \\
\hline Building 3 & 8 is part of the Er & ergy and Environment Directorate. & Small quantities of radiaactive trace & ers are handled in th & $\begin{array}{l}\text { with Potontiat for } \\
\text { is builinase (Ci) }\end{array}$ & $\begin{array}{l}\text { State } \\
\text { Factor } \\
\end{array}$ & & $\begin{array}{c}\text { Diameter } \\
\text { (m) }\end{array}$ & $\begin{array}{l}\text { Velocity } \\
(m / s)\end{array}$ & Device(s) & $\begin{array}{l}\text { Abatement } \\
\text { Factor }\end{array}$ & $\begin{array}{l}\text { Annual Emisions } \\
\text { (Ci) }\end{array}$ & $\begin{array}{l}\text { Distance to } \\
\text { SWMEI }(m)\end{array}$ & $\begin{array}{l}\text { Drecetion } \\
\text { to SwMEl }\end{array}$ & $\begin{array}{c}E D E \\
(\text { mrem })\end{array}$ & $\begin{array}{l}\text { Distance } \\
\text { to MEI (m) }\end{array}$ & \begin{tabular}{|l|} 
Direction \\
to MEI \\
\end{tabular} & $\begin{array}{l}\text { Unabated } \\
\text { EDE (mrem) } \\
\end{array}$ & \\
\hline 378 & 105 & FHE-1,11 & Tracer work & Am-243 & $9.2 E-12$ & $1.0 \mathrm{E}-03$ & 8.5 & 0.30 & 5.8 & None & 1 & $9.2 E-15$ & 875 & ESE & $4.2 E-12$ & 1041 & w & $1.9 E-11$ & 2 \\
\hline & & & & $\begin{array}{l}\frac{P}{P u-239} \\
\text { Put-242 } \\
1+233\end{array}$ & $\begin{array}{l}1.5-14 \\
1.5 E-12 \\
1.611\end{array}$ & $\begin{array}{l}1.0 \mathrm{O}-03 \\
1.00-03 \\
1.0-03\end{array}$ & & & & & & $\begin{array}{l}1.5 E-17 \\
1.5 E-15 \\
1.6-14\end{array}$ & & & & & & & \\
\hline & & & & $0-233$ & 4.6E-11 & $1.0 \mathrm{E}-03$ & & & & & & $4.6 E-14$ & & & & & & & \\
\hline 378 & 120 & FHE- $-1,2,3,4,5,5,8,9,10$ & Tracer work & $\begin{array}{l}\text { Am-241 } \\
\text { Am-243 } \\
\text { Cd } 1099\end{array}$ & $\begin{array}{l}1.27-08 \\
77.7-11 \\
777-09\end{array}$ & $\begin{array}{l}1.00-03 \\
1.0-03 \\
10.03\end{array}$ & 8.5 & 0.30 & 5.9 & None & 1 & $\begin{array}{l}1.2 E-11 \\
7.7 F-14 \\
7.7 F-12\end{array}$ & 875 & ESE & $2.6 \mathrm{E}-09$ & 1041 & w & $1.2 E-08$ & 2 \\
\hline & & & & $\begin{array}{l}\text { Co-57 } \\
\text { Co-60 }\end{array}$ & $\begin{array}{l}3.11-10 \\
.2 E-08\end{array}$ & $\begin{array}{l}1.0 \mathrm{~L}-03 \\
1.0 \mathrm{-O}-03 \\
1.03\end{array}$ & & & & & & 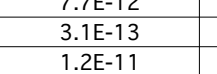 & & & & & & & \\
\hline & & & & $\begin{array}{l}\frac{c s-134}{C s} \\
C s-137\end{array}$ & $\begin{array}{l}1.5-507 \\
1.55-08 \\
1.508\end{array}$ & $\begin{array}{l}1.0-03 \\
1.0-03 \\
100-03\end{array}$ & & & & & & $\frac{1.5-10}{1.55-10}$ & & & & & & & \\
\hline & & & & $\begin{array}{ll}25-237 \\
\text { Np-237 }\end{array}$ & $\begin{array}{l}3.15-13 \\
3.115-13 \\
5-11\end{array}$ & $\begin{array}{l}1.00-03 \\
1.0-03 \\
00-03\end{array}$ & & & & & & $\begin{array}{l}3.5-16 \\
3.15-16 \\
5-14\end{array}$ & & & & & & & \\
\hline & & & & $\begin{array}{l}\text { Pu-239 } \\
\text { Pu-240 }\end{array}$ & $\begin{array}{l}\frac{1.3 E-11}{1.2 E-11} \\
1\end{array}$ & 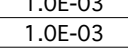 & & & & & & $\begin{array}{l}\frac{1.5 E-14}{1.2 E-14} \\
\end{array}$ & & & & & & & \\
\hline & & & & $\begin{array}{l}\text { Pu-242 } \\
\text { Pu-244 }\end{array}$ & $\begin{array}{l}\frac{1.55-12}{7.7 E-11} \\
\end{array}$ & 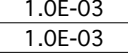 & & & & & & $\begin{array}{l}1.5 E-15 \\
7.7 E-14\end{array}$ & & & & & & & \\
\hline & & & & $\begin{array}{ll}\mathrm{Sr}-85 \\
\mathrm{U}-238\end{array}$ & $\begin{array}{l}1.4 E--08 \\
1.5 E-13\end{array}$ & $\begin{array}{l}1.0 \mathrm{OE}-03 \\
1.00-03 \\
\end{array}$ & & & & & & $\frac{1.4 E-11}{1.5 E-16}$ & & & & & & & \\
\hline & & & & $\begin{array}{l}\mathrm{U}-235 \\
1-234 \\
\end{array}$ & $\begin{array}{l}6.8 E-15 \\
1.65-13 \\
1.013\end{array}$ & $\begin{array}{l}1.0 \mathrm{E}-03 \\
0.03 \\
10.03\end{array}$ & & & & & & $6.8 E-18$ & & & & & & & \\
\hline & & & & $\frac{-2.238}{U-238}$ & $\begin{array}{l}\frac{1.6-13}{2.8-13} \\
2.6-15\end{array}$ & $\begin{array}{l}1.00-03 \\
1.0-03 \\
00-03\end{array}$ & & & & & & $\begin{array}{l}1.6-6-16 \\
2.8-16 \\
28-16\end{array}$ & & & & & & & \\
\hline & & & & $\begin{array}{l}U-235 \\
U-234 \\
U\end{array}$ & $\frac{3.6-14}{2.6 E-14}$ & $\begin{array}{l}1.00-03 \\
1.0 E-03 \\
\end{array}$ & & & & & & 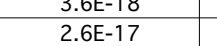 & & & & & & & \\
\hline illiding 4 & 11 was part of the & anium Atomic Vapor Laser Isoto & ee Separation (U-AVLSS) program, op & erated by The Unite & d States Enrichment C & orporation (L) & SSEC). In June 1s & 99, USEC suspe & Ended further deve & elopment of the U-AV & LIS technology. & & & & & & & & \\
\hline $\begin{array}{l}\text { Stack sar } \\
\text { *Air eniss }\end{array}$ & $\begin{array}{l}\text { ppling is contininou } \\
\text { ons are continuou }\end{array}$ & $\begin{array}{l}\text { The facility operates with two in } \\
\text { iy sampled at the post-HEAA-fiter }\end{array}$ & 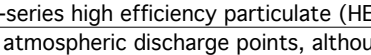 & $\begin{array}{l}\text { EPA) fiter banks to } \\
\text { ugh misssions are lo }\end{array}$ & ontrol emissions. & lonitoring is : & $t$ required per & he NESHAPS 40 & CFR 61 regulatior & ons & & & & & & & & & \\
\hline *\$Because & monitoring takes & lace after HEPA filtration, an unab & ated EDE cannot be determined (see & discussion in Sectic & nII, subsection "Stack & Monitoring f & or Gross Alpha a & d Gross Beta Ra & adiation.") & & & & & & & & & & \\
\hline 491 & All & FFE-1 & Out of service & Gross alpha & * & NA & 9.1 & 0.9 & 12.1 & Double HEPA & 0.0001 & $0.0 E+00$ & 1000 & SSE & $0.0 E+00$ & $\star * *$ & $\star \star \star *$ & ** & 3 \\
\hline & & & & Gross beta & & & & & & & & $0.0 E+00$ & & & & & & & \\
\hline uilding 5 & 3 is operated by & he Radioactive and Hazardous Was & te Management Division. The Stabilili & zation Unit is a mec & anized mixing device & used to make & homogeneous $n$ & ixtures of waste & e. Solidification as & agents are added durin & g mixing to transfe & er sludges to solid & & & & & & & \\
\hline The Micro & iltration Unit filters & out waste radioactive particles. II & the Laboratory, small quantities of & Waste materials are & sampled, treated, and & stored. No & releases are asst & med to occur fr. & rom waste storage & e because the wastes & are fully contained & & & & & & & & \\
\hline 513 & Stabilization & Room Air & $\begin{array}{c}\text { Treatment of hazardous, mixed } \\
\text { or radioaactive waste }\end{array}$ & $\frac{H-3}{U-234}$ & $\begin{array}{l}\text { E-04 } \\
\text { E-08 }\end{array}$ & 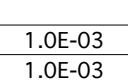 & NA & NA & $\mathrm{NA}$ & None & 1 & $\begin{array}{l}4.1 E-07 \\
5.1-11 \\
5.11\end{array}$ & 528 & NE & $3.4 E-07$ & 217 & sw & $8.3 E-07$ & 1 \\
\hline & & & & $\begin{array}{l}0-235 \\
U-238 \\
-238\end{array}$ & $\begin{array}{l}7.1 E-09 \\
5.5-07\end{array}$ & $\begin{array}{l}1.00-03 \\
1.00-03\end{array}$ & & & & & & 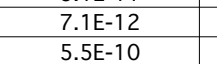 & & 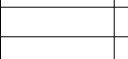 & & & & & \\
\hline 513 & $1000 \mathrm{~A}$ & FHE-4 & Process optimization and & $1-125$ & $7.8 E-07$ & $1.0 \mathrm{E}-03$ & 10.5 & 0.30 & 5.5 & HEPA & 0.01 & $7.8 E-12$ & 588 & NE & $8.7 E-09$ & 128 & sw & 1.3E-08 & 2 \\
\hline & & & treatibility studies & $\frac{1-131}{\text { Cs-137 }}$ & $\begin{array}{l}2.88-5-8 \\
2.55-07\end{array}$ & $\begin{array}{l}1.0 \mathrm{E}-03 \\
1.0 \mathrm{E}-03 \\
\end{array}$ & & & & & & 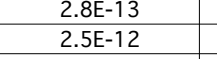 & & & & & & & \\
\hline & & & & $\begin{array}{c}\mathrm{C}-14 \\
\text { Cs-134 }\end{array}$ & 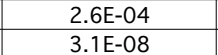 & $\frac{1.0 \mathrm{E}-03}{1.00-03}$ & & & & & & $\begin{array}{l}2.6 E-09 \\
3.1 .-13\end{array}-13$ & & & & & & & \\
\hline & & & & $\frac{B a-133}{P-32}$ & $\begin{array}{l}2.0 E-09 \\
3.3 E-06\end{array}$ & $\begin{array}{l}1.00-03 \\
100-03\end{array}$ & & & & & & 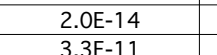 & & & & & & & \\
\hline & & & & $\begin{array}{l}\text { Pu-238 } \\
\text { Du-2329 }\end{array}$ & 年 $1.8 \mathrm{E}$ & $1.0 \mathrm{E}-03$ & & & & & & $\begin{array}{l}0.36-14 \\
1.8-14\end{array}-14$ & & & & & & & \\
\hline & & & & $\begin{array}{l}\text { Put-239 } \\
\text { Pu-240 }\end{array}$ & $\begin{array}{l}1.4-16-18 \\
2.12-08\end{array}$ & $\frac{1.0 \mathrm{E}-03}{1.03}$ & & & & & & $\begin{array}{l}2.4 L-16 \\
2.1 E-13 \\
-12\end{array}$ & & & & & & & \\
\hline & & & & Pu-241 & $1.3 E-06$ & $\frac{1.0}{1.0}$ & & & & & & $|.3 t-1|$ & & & & & & & \\
\hline & 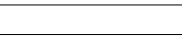 & 然 & & Th-232 & $\begin{array}{l}4.66-09 \\
.76-07\end{array}$ & $\frac{1.0 \mathrm{E}-03}{1.03}$ & & & & & & $4.6-14$ & & & & & & & \\
\hline & & & & Putcic & 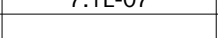 & $1.0 \mathrm{E}-03$ & & & & & & T.IE-12 & & & & & & & \\
\hline 514 & 108 & Room Air & $\begin{array}{l}\text { Vacuum filtration of treated } \\
\text { waste water }\end{array}$ & $\frac{A m-241}{A m-243}$ & $\begin{array}{l}4.2 E-06 \\
1.4-06\end{array}$ & 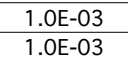 & NA & NA & NA & None & 1 & $\begin{array}{l}4.2 E-09 \\
1.4 \mathrm{E}-09\end{array}$ & 528 & NE & $1.1 \mathrm{E}-04$ & 217 & sw & $2.8 \mathrm{E}-04$ & 1 \\
\hline & & & & Ba-133 & $\frac{1.14}{14}$ & 1.06 & & & & & & $\frac{1.16}{1.45}$ & & & & & & & \\
\hline & & & & $\begin{array}{ll}\text { Be- } \\
\text { Bi-207 }\end{array}$ & $7.3 E-08$ & $\begin{array}{l}1.0 \mathrm{E}-\mathrm{C}-\mathrm{s} \\
1.0 \mathrm{C}\end{array}$ & & & & & & $7.3 \mathrm{E}$ & & & & & & & \\
\hline & & & & $\frac{c-14}{C d-109}-1-1-10$ & 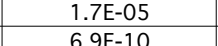 & $\frac{1.0 E-03}{100-03}$ & & & & & & $\frac{1.75}{6.95}$ & & & & & & & \\
\hline & & & & 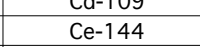 & & $\frac{1.0 \mathrm{C}}{1.0 \mathrm{E}}$ & & & & & & $\frac{6.9}{1.1}$ & & & & & & & \\
\hline & & & & $\mathrm{Cm}-244$ & 0.000 & $1.0 \mathrm{E}-03$ & & & & & & $\frac{1.30-09}{200}$ & & & & & & & \\
\hline & & & & $\begin{array}{ll}0.57 \\
\text { Co-58 }\end{array}$ & $\frac{2.4}{1.2}$ & & & & & & & & & & & & & & \\
\hline & & & & Co-60 & $\begin{array}{lll} & 0\end{array}$ & $\begin{array}{l}1.0 \mathrm{E}-03 \\
1.00-02\end{array}$ & & & & & & 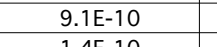 & & & & & & & \\
\hline & & & & Cs-134 & 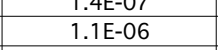 & 1.0E-03 & & & & & & 1.It-09 & & & & & & & \\
\hline & & & & Cs-137 & $7.0 E-06$ & $1.0 \mathrm{E}-03$ & & & & & & 7.0E-09 & & & & & & & \\
\hline
\end{tabular}




\section{Attachment 1 - 2002 LLNL NESHAPs Annual Report Spreadsheet}

\begin{tabular}{|c|c|c|c|c|c|c|c|c|c|c|c|c|c|c|c|c|c|c|c|}
\hline Building & Room/Area & Stack ID & Operation & $\begin{array}{l}\text { Radionuclides } \\
\end{array}$ & $\begin{array}{l}\text { Annual Inventory } \\
\text { with Potential for } \\
\text { Releage (i) }\end{array}$ & $\begin{array}{l}\text { Physical } \\
\text { State } \\
\text { Factor }\end{array}$ & $\begin{array}{l}\text { Stack } \\
\text { Height }(m)\end{array}$ & \begin{tabular}{l}
\multicolumn{1}{c}{ Stack } \\
Diameter
\end{tabular} & $\begin{array}{l}\frac{\text { Stack }}{\text { Velocity }} \\
(m / s)\end{array}$ & $\begin{array}{l}\text { Control } \\
\text { Device(s) } \\
\end{array}$ & $\begin{array}{c}\text { Control Device } \\
\text { Abatement } \\
\text { Factor }\end{array}$ & \begin{tabular}{c|} 
Estimated \\
Annual Emissions \\
$(C)$
\end{tabular} & $\begin{array}{l}\frac{10 \mathrm{mrem} / \mathrm{S} \mathrm{S}}{\text { Distance to }} \\
\text { SWMEI(m) }\end{array}$ & $\begin{array}{l}\text { Tite-Wide Do } \\
\text { Direction } \\
\text { to SSMEI }\end{array}$ & $\begin{array}{c}\text { e Requirement } \\
\text { EDE } \\
\text { (mrem) }\end{array}$ & $\begin{array}{l}\frac{0.1 \mathrm{mrem}}{} \\
\text { Distance } \\
\text { to MEI(m) }\end{array}$ & $\begin{array}{l}\text { Monitoring } \\
\text { Direction } \\
\text { to MII }\end{array}$ & $\begin{array}{l}\text { Requirement } \\
\text { Unabated } \\
\text { DEF (rom) }\end{array}$ & $\begin{array}{l}\text { Source } \\
\text { Category }\end{array}$ \\
\hline 514 & 108 & (continued) & & Eu-152 & $\begin{array}{l}\text { Release (Ci) } \\
.2 E-06\end{array}$ & $\begin{array}{l}\text { Factor } \\
1.0 \mathrm{E}-03 \\
\end{array}$ & & & & & & $\begin{array}{c}(\mathrm{Ci}) \\
4.2 \mathrm{E}-09\end{array}$ & & & & & & & \\
\hline & & & & $\begin{array}{l}\text { Eu-154 } \\
\text { Eut-155 }\end{array}$ & $\begin{array}{l}4.2 E-06 \\
3.3-507\end{array}$ & $\begin{array}{l}1.0 E-03 \\
10.0-03\end{array}$ & & & & & & $\begin{array}{l}4.2 E-09 \\
35-10\end{array}$ & & & & & & & \\
\hline & & & & $\begin{array}{l}\text { Fe-55 } \\
\text { Fe-510 }\end{array}$ & $\begin{array}{l}0.06-17 \\
1.4-07\end{array}$ & $1.0 \mathrm{E}-03$ & & & & & & $\begin{array}{l}3.3 E-10 \\
1.4 E-10\end{array}$ & & & & & & & \\
\hline & & & & 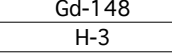 & $\begin{array}{l}\frac{1.1 . E-06}{1.2 E-04} \\
1.25\end{array}$ & $\begin{array}{l}1.0 E-03 \\
1.0 E-03 \\
\end{array}$ & & & & & & $\begin{array}{l}1.11 \mathrm{l}-\mathrm{-}-9 \\
.2 E-07\end{array}$ & & & & & & & \\
\hline & & & & $\begin{array}{ll}\frac{H F}{H}-172 \\
K\end{array}$ & $\begin{array}{l}1.4 E-07 \\
7.0-10\end{array}$ & $\begin{array}{l}1.0 \mathrm{E}-03 \\
1.0 \mathrm{E}-03\end{array}$ & & & & & & $\begin{array}{l}1.4 E-10 \\
7.0 E-13\end{array}$ & & & & & & & \\
\hline & & & & $\begin{array}{l}\frac{L u-174}{\text { MFP }} \\
\end{array}$ & $\begin{array}{l}1.44-07 \\
1.44-10\end{array}$ & $\begin{array}{l}1.0 \mathrm{O}-03 \\
1.00-03\end{array}$ & & & & & & $\begin{array}{l}1.46-10 \\
144-13\end{array}$ & & & & & & & \\
\hline & & & & $\begin{array}{l}\frac{\mathrm{Mn}-54}{\mathrm{~N}-252} \\
\mathrm{~N}-22\end{array}$ & $\begin{array}{l}3.5-07 \\
2.51-05\end{array}$ & 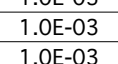 & & & & & & $\begin{array}{l}3.56-10 \\
2.15-08\end{array}$ & & & & & & & \\
\hline & & & & $\frac{N_{p}-237}{N_{p}-32}$ & 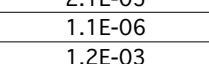 & 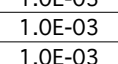 & & & & & & $\begin{array}{l}2.11-08 \\
1.11-09 \\
10.06\end{array}$ & & & & & & & \\
\hline & & & & $\frac{P=3 c}{\mathrm{~Pb}-210}$ & $\begin{array}{l}\frac{1.26-03}{1.2-06} \\
1.06\end{array}$ & $\begin{array}{l}1.06-03 \\
1.0 E-03 \\
10-02\end{array}$ & & & & & & $\begin{array}{l}\frac{1.2 \mathrm{~L}-06}{1.2-09} \\
1-09\end{array}$ & & & & & & & \\
\hline & & & & $\begin{array}{l}\text { Put-238 } \\
\text { Put-239 }\end{array}$ & $\begin{array}{l}2.8 E-06 \\
1.1 E-05 \\
\end{array}$ & $\begin{array}{l}1.0 E-03 \\
1.0 E-03 \\
\end{array}$ & & & & & & $\begin{array}{l}2.88-09 \\
1.1 E-08 \\
\end{array}$ & & & & & & & \\
\hline & & & & $\begin{array}{l}\text { Pu-240 } \\
\text { Puu-241 }\end{array}$ & $\begin{array}{l}3.3 .-08 \\
1.5 E-07 \\
\end{array}$ & $\begin{array}{l}1.0 \mathrm{E}-\mathrm{-}-3 \\
1.0 \mathrm{E}-03 \\
\end{array}$ & & & & & & $\begin{array}{r}3.3 .-11 \\
1.5 E-10 \\
\end{array}$ & & & & & & & \\
\hline & & & & $\begin{array}{l}\text { Pu-242 } \\
\text { Puu-244 }\end{array}$ & $\begin{array}{l}\frac{1.1 \mathrm{E}-\mathrm{-}-6}{2.2 \mathrm{E}-08} \\
\end{array}$ & $\begin{array}{l}\frac{1.0 \mathrm{E}-03}{1.0 \mathrm{O}-03} \\
\end{array}$ & & & & & & $\begin{array}{l}1.11-09 \\
2.88-11\end{array}$ & & & & & & & \\
\hline & & & & $\begin{array}{l}\text { Ra-226 } \\
\text { Sb-125 }\end{array}$ & $\begin{array}{l}9.1 \mathrm{~L}-08 \\
3.35-07 \\
\end{array}$ & $\begin{array}{l}1.0 \mathrm{C}-03 \\
1.0-03 \\
100-03\end{array}$ & & & & & & 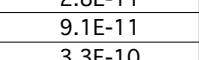 & & & & & & & \\
\hline & & & & 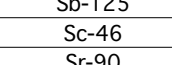 & 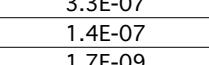 & $\begin{array}{l}1.00-03 \\
1.0 E-03 \\
100-03\end{array}$ & & & & & & $\begin{array}{l}\text { S.SE-10 } \\
1.46-10\end{array}$ & & & & & & & \\
\hline & & & & 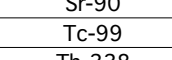 & 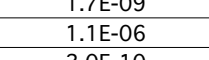 & $\begin{array}{l}1.00-03 \\
1.0 E-03 \\
1.03\end{array}$ & & & & & & $\begin{array}{l}.1 .1-12 \\
1.1-09 \\
-09\end{array}$ & & & & & & & \\
\hline & 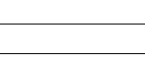 & & & $\begin{array}{l}\text { Th-228 } \\
\text { Th-229 }\end{array}$ & $\begin{array}{l}\frac{2.0 E-10}{1.1 E-06} \\
1.06\end{array}$ & $\begin{array}{l}1.0 E-03 \\
1.0 E-03 \\
\end{array}$ & & 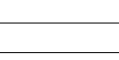 & 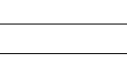 & & & $\begin{array}{l}2.00-13 \\
1.11-09 \\
\end{array}$ & & & & & & & \\
\hline & & & & $\begin{array}{l}\text { Th-230 } \\
\text { Th-232 }\end{array}$ & $\begin{array}{l}\frac{1.1 E-06}{1.3 E-06} \\
\end{array}$ & $\frac{1.00-03}{1.0 E-03}$ & & & & & & $\begin{array}{l}1.1 \mathrm{E}-\mathrm{-}-9 \\
1.3 \mathrm{E}-09\end{array}$ & & & & & & & \\
\hline & -5 & & & $\frac{U-232}{U-233}$ & $\begin{array}{l}1.1 \mathrm{E}-06 \\
1.1-0.06\end{array}$ & $\begin{array}{l}1.0 E-03 \\
10.0-03\end{array}$ & & & & & & $\begin{array}{l}1.1 \mathrm{IE}-09 \\
1.11-09\end{array}$ & & & & & & & \\
\hline & 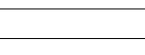 & & & U-234 & $\begin{array}{l}2.11-05 \\
2.15-06 \\
25\end{array}$ & $\begin{array}{l}1.00-03 \\
1.0-03 \\
10-03\end{array}$ & & & & & & 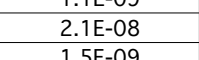 & & & & & & & \\
\hline & -5 & & & $\frac{1}{u-238}$ & $\begin{array}{l}8.25-05 \\
8.2-05 \\
270-10\end{array}$ & $\begin{array}{l}1.00-03 \\
1.0 E-03 \\
\end{array}$ & & & & & & $\begin{array}{l}.25-09 \\
8.2-08 \\
\end{array}$ & & & & & & & \\
\hline & & & & & & & & & & & & $2.1-15$ & & & & & & & \\
\hline 514 & Evaporator & Room Air & Waste consolidation & Am-241 & $\begin{array}{l}\frac{4.5 E-05}{1.5 E-05} \\
\end{array}$ & $\begin{array}{l}1.0 E-03 \\
1.0 E-03 \\
\end{array}$ & NA & NA & NA & None & 1 & $\begin{array}{l}4.55-08 \\
1.5 E-08 \\
\end{array}$ & 528 & NE & $1.2 E-03$ & 217 & sw & 3.1E-03 & 1 \\
\hline & & & & $\begin{array}{l}\text { Ba-1333 } \\
\text { Be-7 }\end{array}$ & $\begin{array}{l}1.25-505 \\
1.55-06\end{array}$ & $\begin{array}{l}1.0 \mathrm{E}-\mathrm{E}-3 \\
1.0 \mathrm{E}-03\end{array}$ & & & & & & $\begin{array}{l}1.25-08 \\
1.5 E-09\end{array}$ & & & & & & & \\
\hline & & & & $\begin{array}{ll}\text { Bi-207 } \\
\text { C-14 }\end{array}$ & 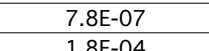 & $1.0 E-03$ & & & & & & $7.8 E-10$ & & & & & & & \\
\hline & & & & $\begin{array}{l}\text { C-14 } \\
\text { Cd-109 }\end{array}$ & $\begin{array}{l}1.8 E-04 \\
7.4 E-09 \\
7\end{array}$ & $\begin{array}{l}1.0 E-03 \\
.0 E-03 \\
\end{array}$ & & & & & & $\begin{array}{l}1.8-8-07 \\
7.4 E-12\end{array}$ & & & & & & & \\
\hline & & & & Ce-144 & $\begin{array}{l}1.2 E-04 \\
1.450 .05\end{array}$ & $1.0 E-03$ & & & & & & $\begin{array}{l}1.22-07 \\
1.15=0.09\end{array}$ & & & & & & & \\
\hline & & & & Cm-244 & $23 E-06$ & $\begin{array}{l}1.0 E-03 \\
10 E-03\end{array}$ & & & & & & $\begin{array}{l}1.4 \mathrm{E}-08 \\
233-09\end{array}$ & & & & & & & \\
\hline & & & & Co-58 & 告. & $\begin{array}{l}1.0 \mathrm{E}-03 \\
1.03\end{array}$ & & & & & & $1.5 \mathrm{E}-09$ & & & & & & & \\
\hline & & & & $\frac{c_{0}^{0-60}}{\text { Cr-51 }}$ & $\begin{array}{l}\frac{9.7 F-06}{1.5 E-06} \\
\end{array}$ & $\begin{array}{l}1.0 \mathrm{E}-\mathrm{E}-3 \\
1.0 \mathrm{E}-03 \\
\end{array}$ & & & & & & $\begin{array}{l}9.75-99 \\
1.5-09\end{array}$ & & & & & & & \\
\hline & & & & $c s-134$ & $1.2 E-05$ & $1.0 \mathrm{E}-03$ & & & & & & $1.2 \mathrm{E}-08$ & & & & & & & \\
\hline & & & & $\begin{array}{l}\text { Css-177 } \\
\text { Eu-152 }\end{array}$ & $4.5 E-05$ & $\begin{array}{l}1.0 \mathrm{E}-\mathrm{-}-3 \\
1 . \mathrm{E}-03 \\
\end{array}$ & & & & & & $4.5 E-08$ & & & & & & & \\
\hline & & & & Eu-154 & $4.5-05$ & $1.0 \mathrm{E}-03$ & & & & & & $\begin{array}{l}4.5-5=0 \\
4.5 E-08 \\
\end{array}$ & & & & & & & \\
\hline & & & & Eu-155 & $3.5 E-06$ & $1.0 \mathrm{E}-03$ & & & & & & 3.5E-09 & & & & & & & \\
\hline & & & & $\begin{array}{l}\text { Fe-55 } \\
\text { Gd-148 }\end{array}$ & $\begin{array}{l}\frac{1.5 E-06}{1.2-05} \\
1.25\end{array}$ & $\begin{array}{l}1.0 \mathrm{E}-\mathrm{E}-3 \\
1.0 \mathrm{E}-03\end{array}$ & & & & & & $\begin{array}{l}\frac{1.5 E--09}{1.2-08} \\
1-08\end{array}$ & & & & & & & \\
\hline & & & & $\mathrm{H}-3$ & $1.2 \mathrm{E}-03$ & $1.0 \mathrm{E}-03$ & & & & & & $1.2 \mathrm{E}-06$ & & & & & & & \\
\hline & & & & $\begin{array}{ll}H f-172 \\
K-40\end{array}$ & $\begin{array}{l}1.5 E-06 \\
75-509\end{array}$ & $1.0 E-03$ & & & & & & $\begin{array}{l}1.5 E-09 \\
75=12\end{array}$ & & & & & & & \\
\hline & & & & Ku-40 & $\begin{array}{r}. .5 E-09 \\
1.5-06\end{array}$ & $\begin{array}{l}1.0 E-03 \\
1.0 E-03\end{array}$ & & & & & & $\begin{array}{l}1.5-5-12 \\
.5 E-09 \\
\end{array}$ & & & & & & & \\
\hline & & & & $\begin{array}{l}\text { MFP } \\
\text { MF-5 }\end{array}$ & $\begin{array}{l}1.5 E-09 \\
375-0.06\end{array}$ & 1.06 & & & & & & $\begin{array}{l}1.5 E-12 \\
37 E-09\end{array}$ & & & & & & & \\
\hline & & & & Nan-22 & $\begin{array}{l}3.1 .6-06 \\
2.6 E-06\end{array}$ & $\begin{array}{l}1.0 E-03 \\
1.0 E-03 \\
\end{array}$ & & & & & & $\begin{array}{l}3.1 \mathrm{E} \\
2.6 \mathrm{E}\end{array}$ & & & & & & & \\
\hline & & & & \begin{tabular}{|l|l|l|} 
Np-237 \\
0.27
\end{tabular} & $1.2 E-05$ & $1.0 \mathrm{E}-03$ & 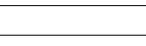 & 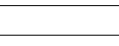 & 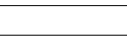 & & & $1.2 \mathrm{E}-08$ & & & & & & & \\
\hline & & & & $\frac{P b-210}{P b-210}$ & $\begin{array}{l}0.4-4 E \\
1.3 E-05 \\
\end{array}$ & $\begin{array}{l}\frac{1.0 E-C S}{1.0 E-03} \\
\end{array}$ & & & & & & $\begin{array}{l}6.4 .4-6-6 \\
1.3 E-08\end{array}$ & & & & & & & \\
\hline & & & & $\begin{array}{l}\text { Pu-238 } \\
\text { Put-239 }\end{array}$ & 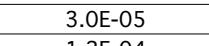 & 1.0 & & & & & & $\begin{array}{l}3.00-08 \\
.0-027\end{array}$ & & & & & & & \\
\hline & & & & 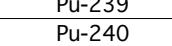 & $\begin{array}{l}1.2 E-C 4 \\
3.2 E-07 \\
\end{array}$ & $\begin{array}{l}1.0 \mathrm{E}-\mathrm{E}-3 \\
1.0 \mathrm{E}-03 \\
\end{array}$ & & & & & & $\frac{1.2}{3.2}$ & & & & & & & \\
\hline & & & & $\begin{array}{l}\text { Pu- } 241 \\
0.213\end{array}$ & $\frac{1.3-06}{20-0.25}$ & 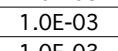 & & & & & & $\begin{array}{l}1.30-09 \\
12500\end{array}$ & & & & & & & \\
\hline & & & & $\begin{array}{l}\text { Put-c4 } \\
\text { Pur-244 }\end{array}$ & $3.0 \mathrm{E}-07$ & & & & & & & $1 . \angle E-08$ & & & & & & & \\
\hline & & & & Ra-226 & $9.7 E-07$ & $1.0 E-03$ & & & & & & $\begin{array}{l}9.7 E-10 \\
9.70\end{array}$ & & & & & & & \\
\hline
\end{tabular}




\section{Attachment 1 - 2002 LLNL NESHAPs Annual Report Spreadsheet}

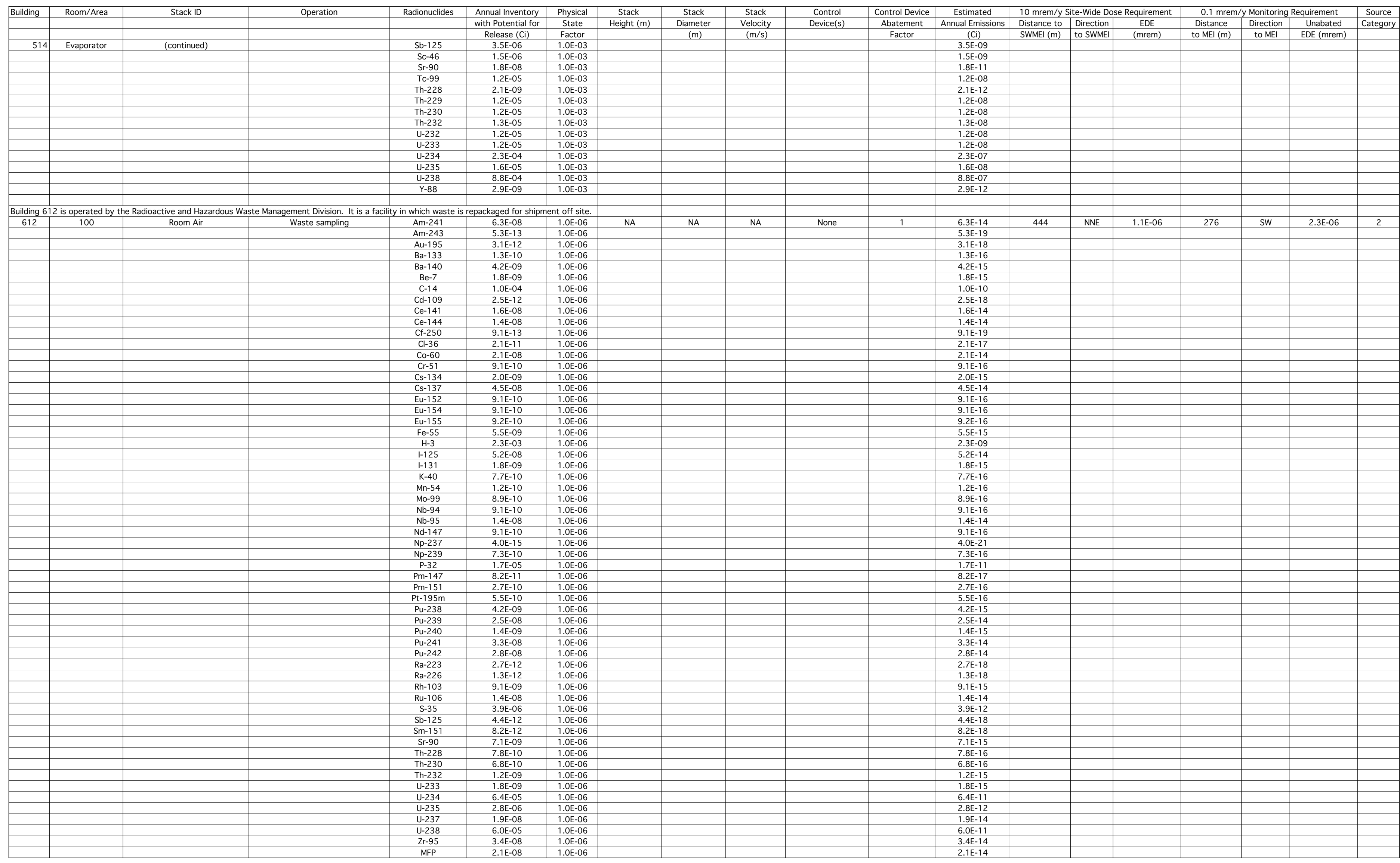




\section{Attachment 1 - 2002 LLNL NESHAPs Annual Report Spreadsheet}

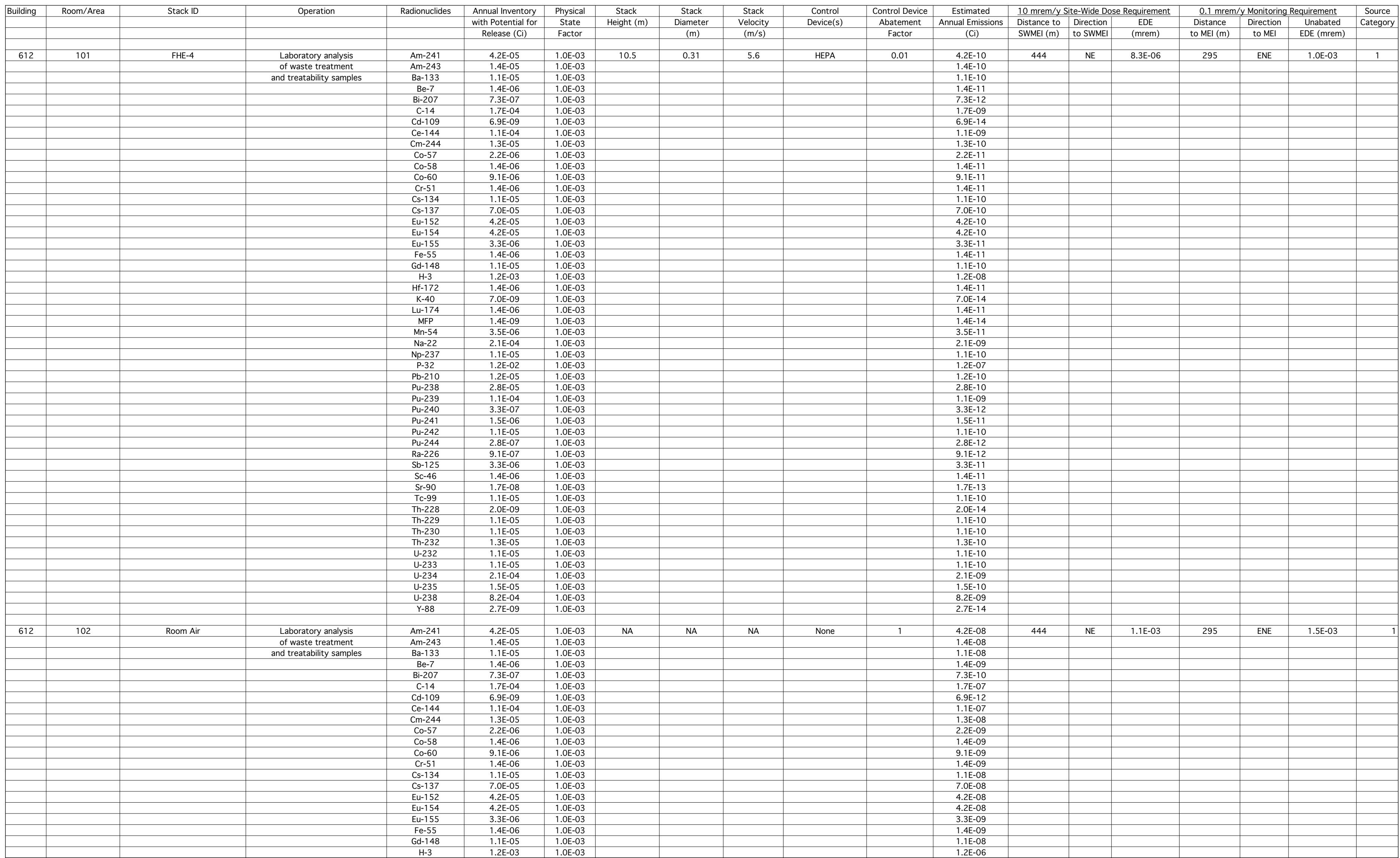




\section{Attachment 1 - 2002 LLNL NESHAPs Annual Report Spreadsheet}

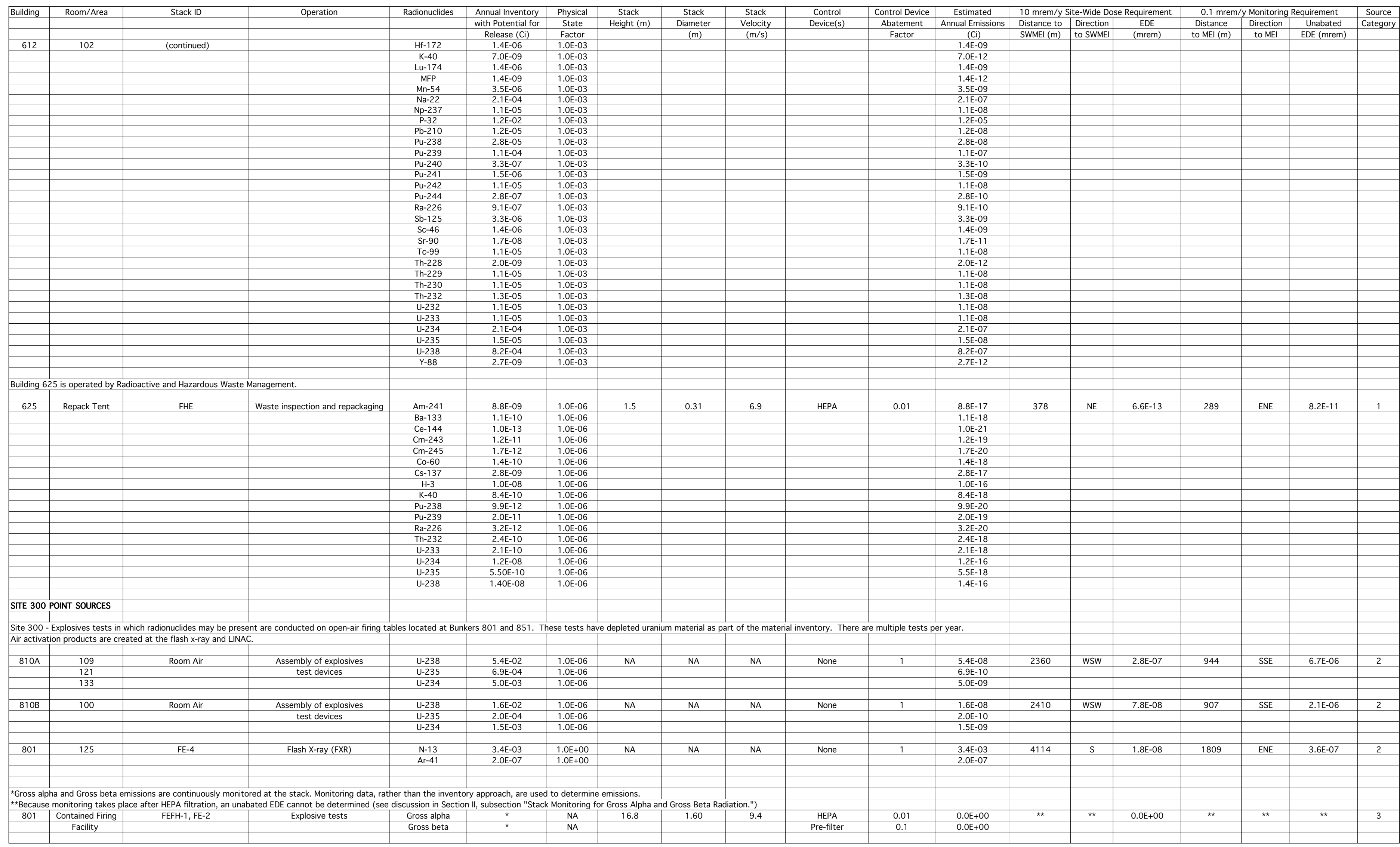


Attachment 1 - 2002 LLNL NESHAPs Annual Report Spreadsheet

\begin{tabular}{|c|c|c|c|c|c|c|c|c|c|c|c|c|c|c|c|c|c|c|c|}
\hline Building & Room/Area & Stack ID & Operation & Radionuclides & $\begin{array}{l}\text { Annual Inventory } \\
\text { with Dotontil for }\end{array}$ & $\begin{array}{l}\text { Physical } \\
\text { Syical }\end{array}$ & \begin{tabular}{l|l} 
Stack \\
Heicht (m)
\end{tabular} & $\begin{array}{l}\text { Stack } \\
\text { Ditumtar }\end{array}$ & $\begin{array}{l}\text { Stack } \\
\text { Velocity }\end{array}$ & $\begin{array}{c}\text { Control } \\
\text { Doxical }\end{array}$ & $\begin{array}{l}\text { Control Device } \\
\text { AAtatement } \\
\end{array}$ & $\begin{array}{l}\text { Estimated } \\
\text { Annual Emissions }\end{array}$ & \begin{tabular}{|l|l|l}
$10 \mathrm{mrem} / \mathrm{y} \mathrm{s}$ \\
Distance to
\end{tabular} & $\begin{array}{l}\text { Site-Wide Dos } \\
\text { Diretion } 1\end{array}$ & $\begin{array}{l}\text { ose Requirement } \\
\text { EDE }\end{array}$ & $\frac{0.1 \mathrm{mrem} / \mathrm{y}}{\text { Disance }}$ & $\begin{array}{l}\text { M Monitoring: } \\
\text { Direction }\end{array}$ & $\begin{array}{l}\text { gRequirement } \\
\text { Unabated }\end{array}$ & $\begin{array}{l}\text { Source } \\
\text { Catagory }\end{array}$ \\
\hline & & & & & $\begin{array}{l}\text { With Potential for } \\
\text { Release (Ci) }\end{array}$ & $\begin{array}{l}\text { SState } \\
\text { Factor }\end{array}$ & Height (m) & $\begin{array}{l}\text { Diameter } \\
(\mathrm{m})\end{array}$ & $\begin{array}{l}\text { Velocity } \\
(m / s)\end{array}$ & & $\begin{array}{l}\text { Abatement } \\
\text { Factor }\end{array}$ & $\begin{array}{l}\text { Annual Emissions } \\
\text { (Ci) }\end{array}$ & \begin{tabular}{|l} 
Distance to \\
SWMEI (m)
\end{tabular} & \begin{tabular}{|l|} 
Direction \\
to SWMEI
\end{tabular} & \begin{tabular}{|c|} 
(mDE \\
(mem)
\end{tabular} & $\begin{array}{l}\text { Distance } \\
\text { to MEI (m) }\end{array}$ & \begin{tabular}{|c|} 
Direction \\
to MEI
\end{tabular} & $\begin{array}{l}\text { nnabated } \\
\text { EDE (mrem) }\end{array}$ & \\
\hline 851 & Firing Table & None & Explosive tests & U-238 & $1.5 \mathrm{E}-02$ & $1.0 E+00$ & NA & $\mathrm{NA}$ & NA & None & 1 & $1.5 \mathrm{E}-02$ & 3170 & SSE & $1.8 \mathrm{E}-02$ & 1396 & wsw & $2.0 \mathrm{E}-02$ & 4 \\
\hline & & & & $\begin{array}{l}-u 235 \\
U-234\end{array}$ & $\begin{array}{l}2.0 E-04 \\
1.4 E-03 \\
\end{array}$ & $\frac{1.0 E+00}{1.0 E+00}-2-35$ & & & & & & $\begin{array}{l}2.0 \mathrm{E}-04 \\
1.4 \mathrm{E}-03\end{array}$ & & & & & & & \\
\hline 851 & 111 & None & Linear accelerator & $\mathrm{N}-13$ & $8.2 E-02$ & $1.0 E+00$ & NA & NA & NA & None & 1 & $8.2 E-02$ & 3170 & SSE & $1.6 E-06$ & 3836 & ENE & $2.1 E-06$ & 2 \\
\hline & & & & Ar-41 & $1.5 \mathrm{E}-04$ & \begin{tabular}{|l|}
$1.0 \mathrm{E}+00$ \\
\end{tabular} & & & & & & $\frac{7.6 \mathrm{E}-0 \mathrm{c}}{1.5 \mathrm{E}-04}$ & & & & & & & \\
\hline & & & & & & & & & & & & & & & & & & & \\
\hline LIVERMOF & SITE DIFFUSE SO & URCES & & & & & & & & & & & & & & & & & \\
\hline Building 2 & 2 - Diffuse emissi & ins result from tritium-contaminat & ed water which leaked from an unders & ground storage tank. & Vegetation in the ar & ea transpires $\mathrm{s}$ & water with elevat & ated tritium conc & entrations. & & & & & & & & & & \\
\hline 292 & Spill Area & None & Evaporation and transpiration & H-3 & NA & 1 & NA & NA & NA & None & 1 & 4.9E-04 & 1380 & ESE & $7.2 \mathrm{E}-08$ & 456 & $\mathrm{~N}$ & $18 E-06$ & 6 \\
\hline-1 & proment & & 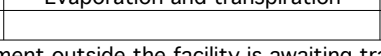 & & & 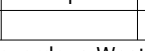 & & & & & & (n) & 1000 & 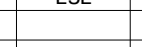 & 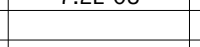 & 655 & w & $1.8 \mathrm{E}-06$ & 5 \\
\hline $\begin{array}{l}\text { Building } 3 \\
\text { ButkThe }\end{array}$ & $\begin{array}{l}1 \text { - As part of D\&L } \\
\text { se from HTO emiss }\end{array}$ & $\begin{array}{l}\text { operations, contamininated equipt } \\
\text { ions calculatade usina the NEWTR }\end{array}$ & 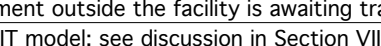 & $\begin{array}{l}\text { ansport and storage b } \\
\text { n. subsection "Modelin }\end{array}$ & $\begin{array}{l}\text { by Radioactive and } \mathrm{H} \\
\text { ing Dose from Tritium }\end{array}$ & azardous Wast & te Management. & & & & & & & & & & & & \\
\hline 331 & Outside & None & Storage of contaminated parts & $\mathrm{H}-3$ & $N A$ & 1 & NA & NA & NA & None & 1 & $1.0 \mathrm{E}+00$ & 957 & ENE & $8.7 \mathrm{E}-04$ & 441 & SSW & $2.66-03$ & 6 \\
\hline & & & & & & & & & & & & & & & & & & secos & \\
\hline $\begin{array}{l}\text { Buildidg } 5 \\
\text { consisting }\end{array}$ & $\begin{array}{l}\frac{4 \text { is operated by } t}{\text { of neutratization, } \mathrm{t}} \\
\text { tat }\end{array}$ & $\begin{array}{l}\text { ne Radioactive and Hazardous Wa } \\
\text { loculation, oxidation, reduction, }\end{array}$ & $\begin{array}{l}\text { ste Managamement Division. The wastev } \\
\text { orecipitation, separation, and filtration }\end{array}$ & $\begin{array}{l}\text { Water treatment tank } \\
\text { Areas used for stor }\end{array}$ & $\begin{array}{l}\mathrm{k} \text { farm and storage ta } \\
\text { rage are not consider }\end{array}$ & $\begin{array}{l}\text { nk a a ea proces } \\
\text { ed to release t. }\end{array}$ & $\begin{array}{l}\text { stese the lilicuid wa } \\
\text { radionuclides bec }\end{array}$ & $\begin{array}{l}\text { avatsa from faciliti } \\
\text { cause the waste: }\end{array}$ & $\begin{array}{l}\text { es on site. The tr } \\
\text { s are fully contain }\end{array}$ & $\begin{array}{l}\text { treatment process } \mathrm{me} \\
\text { ined. }\end{array}$ & involve batch cl & emical treatment & & & & & & & \\
\hline 514 & Tank Farm & Area Source & Process liquid hazardous & \begin{tabular}{|l|} 
Am-241 \\
\end{tabular} & $1.5 \mathrm{E}-05$ & \begin{tabular}{|l|}
$1.0 \mathrm{E}-03$ \\
\end{tabular} & NA & NA & NA & None & 1 & $1.5 \mathrm{E}-08$ & 528 & NE & 4.1E-04 & 217 & SW & $1.2 \mathrm{E}-03$ & 5 \\
\hline & & & $\begin{array}{l}\text { mixed and radioactive wastes in } \\
\text { open tooped tanks. }\end{array}$ & Am-243 & $\begin{array}{ll}4.8 \mathrm{E}-06 \\
3.95-06\end{array}$ & $\begin{array}{l}1.06-03 \\
1.0-0.03\end{array}$ & & & & & & $\begin{array}{l}4.86-09 \\
.00-09\end{array}$ & & & & & & 20 & \\
\hline & & & & Be-7 & $5.0 E-07$ & $1.06-03$ & & & & & & $\frac{1.0-10}{5.0-10}$ & & & & & & & \\
\hline & & & & Bi-207 & 2.6E-07 & $1.0 E-03$ & & & & & & $2.6 E-10$ & & & & & & & \\
\hline & & & & $\frac{C-14}{C-119}$ & $\begin{array}{l}6.0-05 \\
.5-0.9 \\
509\end{array}$ & 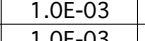 & & & & & & 6.0.0-08 & & & & & & & \\
\hline & & & & Ce-144 & $\begin{array}{ll}2.05-09 \\
4.0 E-05\end{array}$ & $\begin{array}{ll}1.0 E-03 \\
1.0 E-03 \\
\end{array}$ & & & & & & 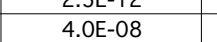 & & & & & & & \\
\hline & & & & Cm-244 & $\begin{array}{l}4.6 E-06 \\
7.0507\end{array}$ & $1.06-03$ & & & & & & $\begin{array}{l}4.6-09 \\
70.10\end{array}$ & & & & & & & \\
\hline & & & & $\frac{10-57}{C 0-58}$ & 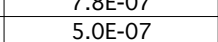 & $\begin{array}{ll}1.0 E-03 \\
1.0 E-03\end{array}$ & & & & & & $\begin{array}{l}\frac{1.0 E-10}{5.0 E-10} \\
5\end{array}$ & & & & & & & \\
\hline & & & & Co-60 & $3.2 E-06$ & $1.0 \mathrm{E}-03$ & & & & & & 3.2E-09 & & & & & & & \\
\hline & & & & $\frac{(r-5)}{C s-134}$ & $\begin{array}{l}5.0 E-07 \\
4.0 E-06\end{array}$ & $\begin{array}{l}\frac{1.0 E-03}{1.0=-03}-3 \\
1.03\end{array}$ & & & & & & 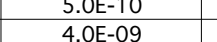 & & & & & & & \\
\hline & & & & Cs-137 & $2.5 E-05$ & $1.0 E-03$ & & & & & & $2.5 E-08$ & & & & & & & \\
\hline & & & & Eu-152 & $1.5 E-05$ & $1.0 E-03$ & & & & & & $1.5 \mathrm{E}-08$ & & & & & & & \\
\hline & & & & Eu-154 & $\frac{1.5 E-05}{1.250}$ & $1.06-03$ & & & & & & 1.5E-08 & & & & & & & \\
\hline & & & & $\begin{array}{l}\text { Eut } 155 \\
\text { Fe-55 }\end{array}$ & $\begin{array}{l}1.2-5-60 \\
5.0 E-07\end{array}$ & \begin{tabular}{|l|l|}
$1.0 E-0.03$ \\
$1.0 E-03$ \\
\end{tabular} & & & & & & $\begin{array}{l}1.2-5=9 \\
5.0-10\end{array}$ & & & & & & & \\
\hline & & & & Gd-148 & $\begin{array}{l}4.0 E-06 \\
.5-014\end{array}$ & $1.0 E-03$ & & & & & & $\begin{array}{l}4.0 \mathrm{E}-09 \\
-19\end{array}$ & & & & & & & \\
\hline & & & & $\frac{H-3}{H f-172}$ & $\begin{array}{l}4.5 E-04 \\
5.0 E-07\end{array}$ & 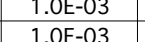 & & & & & & 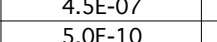 & & & & & & & \\
\hline & & & & $k-40$ & $2.5 E-09$ & $1.06-03$ & & & & & & $2.5 E-12$ & & & & & & & \\
\hline & & & & Lu-174 & $5.0 E-07$ & $1.06-03$ & & & & & & $\begin{array}{l}5.0 E-10 \\
.0-12\end{array}$ & & & & & & & \\
\hline & & & & Mn-54 & 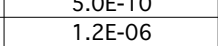 & $\begin{array}{l}1.0 E-03 \\
1.0 E-03\end{array}$ & & & & & & 1.2E-09 & & & & & & & \\
\hline & & & & Na-22 & $7.5 E-05$ & $1.06-03$ & & & & & & 7.5E-08 & & & & & & & \\
\hline & & & & $\begin{array}{l}\mathrm{Np}-237 \\
0.32 \\
0.32\end{array}$ & $\begin{array}{l}4.0 E-06 \\
411-03\end{array}$ & $\frac{1.0 E=-03}{100-03}$ & & & & & & $\begin{array}{l}4.0 E-09 \\
410-06\end{array}$ & & & & & & & \\
\hline & & & & $\mathrm{Pb}-210$ & 4.4E- -06 & $1.06-03$ & & & & & & $\begin{array}{ll}4.1 .4-09 \\
4.4-09\end{array}$ & & & & & & & \\
\hline & & & & $\begin{array}{l}\text { Put-238 } \\
\text { u }\end{array}$ & 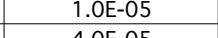 & $1.0 E-03$ & & & & & & $1.0 E-08$ & & & & & & & \\
\hline & & & & 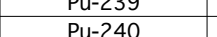 & 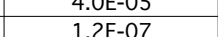 & 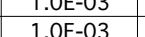 & & & & & & $\begin{array}{l}4.0-0=68 \\
1,2=10\end{array}$ & & & & & & & \\
\hline & & & & $\frac{14-241}{\text { Put }}$ & $5.2 E-07$ & 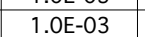 & & & & & & $5.2 E-10$ & & & & & & & \\
\hline & & & & Pu-242 & 4.0E-06 & $1.0 \mathrm{E}-03$ & & & & & & $\begin{array}{l}4.0 \mathrm{E}-09 \\
\end{array}$ & & & & & & & \\
\hline & & & & Pu-244 & 1.0E-07 $72-1$ & 1.0E-03 2010 & & & & & & 1.0E-10 10 - & & & & & & & \\
\hline & & & & Ra-226 & 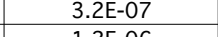 & $1.0 \mathrm{DE}-03$ & & & & & & $3.22=10$ & & & & & & & \\
\hline & & & & Sc-46 & $\begin{array}{ll}1.2-00 \\
5.0 E-07\end{array}$ & $\begin{array}{ll}1.0 E-03 \\
1.06-03\end{array}$ & & & & & & $5.0 E-10$ & & & & & & & \\
\hline & & & & $\begin{array}{l}\text { Sr-90 } \\
\text { T-ca9 }\end{array}$ & $\begin{array}{l}6.1 E-09 \\
40-506\end{array}$ & $\begin{array}{l}1.0 E-03 \\
100-03\end{array}$ & & & & & & $\begin{array}{l}6.1 E-12 \\
40-509\end{array}$ & & & & & & & \\
\hline & & & & Th-228 & $7.0-10$ & $1.0=-03$ & & & & & & $7.0=-13$ & & & & & & & \\
\hline & & & & Th-229 & $\begin{array}{l}4.0 \mathrm{E}-06 \\
-06\end{array}$ & $1.06-03$ & & -5 & & & & 4.0E-09 & & & & & & & \\
\hline & & & & $\begin{array}{l}\text { Th-2330 } \\
\text { Th-232 }\end{array}$ & 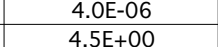 & 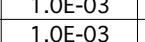 & & & & & & $\begin{array}{l}4.0 E-99 \\
4.5-03 \\
4\end{array}$ & & & & & & & \\
\hline & & & & 0 & $\begin{array}{l}4.0 E-06 \\
.0-06\end{array}$ & $1.0 \mathrm{E}-03$ & & & & & & $4.0 \mathrm{E}-09$ & & & & & & & \\
\hline & & & & $\begin{array}{l}0-233 \\
U-234\end{array}$ & $\begin{array}{l}3.9 E-06 \\
7.5 E-05\end{array}$ & $\begin{array}{l}1.0 E-03 \\
1.0 E-03\end{array}$ & & & & & & $\begin{array}{l}3.9-5-99 \\
7.5 E-08\end{array}$ & & & & & & & \\
\hline & & & & $\frac{0-235}{U-230}$ & $5.5 E-06$ & $1.06-03$ & & & & & & $5.5 E-09$ & & & & & & & \\
\hline & & & & $\frac{-2-28}{-388}$ & $\begin{array}{l}2.9 \mathrm{E}-\mathrm{-}-4 \\
9.5 \mathrm{E}-10\end{array}$ & 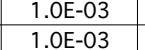 & & & & & & 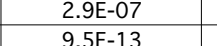 & & & & & & & \\
\hline & & & & & & & & & & & & & & & & & & & \\
\hline
\end{tabular}


Attachment 1 - 2002 LLNL NESHAPs Annual Report Spreadsheet

\begin{tabular}{|c|c|c|c|c|c|c|c|c|c|c|c|c|c|c|c|c|c|c|c|}
\hline Building & Room/Area & Stack ID & Operation & Radionuclides & \begin{tabular}{|l|} 
Annual Inventory \\
with Potential for \\
Release (Ci)
\end{tabular} & \begin{tabular}{|c|} 
Physical \\
State \\
Factor \\
\end{tabular} & $\begin{array}{l}\text { Stack } \\
\text { Height }(m)\end{array}$ & $\begin{array}{c}\text { Stack } \\
\text { Diameter } \\
(\mathrm{m})\end{array}$ & \begin{tabular}{|c|} 
Stack \\
Velocity \\
$(\mathrm{m} / \mathrm{s})$ \\
\end{tabular} & $\begin{array}{c}\text { Control } \\
\text { Device(s) } \\
\end{array}$ & \begin{tabular}{|c|} 
Control Device \\
Abatement \\
Factor
\end{tabular} & \begin{tabular}{|c|} 
Estimated \\
Annual Emissions \\
(i)
\end{tabular} & \begin{tabular}{|l|}
$10 \mathrm{mrem} / \mathrm{s} \mathrm{S}$ \\
Distance to \\
SWWMMI(m)
\end{tabular} & $\begin{array}{l}\text { ite-Wide Dos } \\
\text { Direction } \\
\text { to swMME| }\end{array}$ & $\begin{array}{c}\text { se Requirement } \\
E D E \\
\text { (mrem })\end{array}$ & $\begin{array}{l}0.1 \mathrm{mrem} / \\
\text { Distance } \\
\text { to MEF }(\mathrm{m} \\
\end{array}$ & 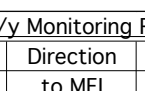 & $\begin{array}{l}\text { Requirement } \\
\text { Unabated } \\
\text { ED (mrem) }\end{array}$ & \begin{tabular}{|c|} 
Source \\
Category \\
\end{tabular} \\
\hline he Buildin & 612 Yard is opet & ated by the Radioactive and Hazar & dous Waste Management Division. T & Yard consists of & & $\begin{array}{l}\text { Factor } \\
\text { ntainers havin } \\
\text { nate }\end{array}$ & radioactive wa & & & containers, which are & & & & & & & & & \\
\hline 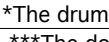 & sampling operatio & $n$ takes place at all site Waste Acc & umulation Areas. Inventories were cc & mbined and modeled & a s if the operation of & Ecurred at the & center of the si & & & & & & & & & & & & \\
\hline 612 & Yard & 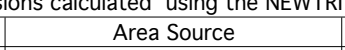 & 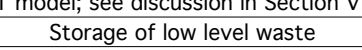 & $H-3$ & $\begin{array}{l}\text { ing Dose erom } \\
\mathrm{NA}\end{array}$ & NA & NA & $\mathrm{NA}$ & $N A$ & None & 1 & $23 \mathrm{E}+00$ & 444 & II & & 276 & sw & & \\
\hline & & & storage or tow tevel waste & & & $\mathrm{NA}$ & $N A$ & $N A$ & NAA & None & 1 & $2.3++00$ & 444 & NVE & $\frac{1.1 \mathrm{E}-0 \mathrm{C}}{* * 8.3 \mathrm{E}-03}$ & 210 & $5 \mathrm{~W}$ & $\frac{2.4 \mathrm{~L}-02}{* * 1.8 \mathrm{E}-02}$ & \\
\hline 612 & All WAAs* ${ }^{*}$ & Area source & Drum sampling in & Am-241 & $4.1 E-10$ & $1.0 \mathrm{E}-03$ & NA & NA & NA & None & 1 & 4.1E-13 & 951 & ESE & $8.5 E-09$ & 969 & w & $5.1 \mathrm{E}-08$ & 5 \\
\hline & & & $\begin{array}{l}612 \text { ayd and all LLNL Waste } \\
\text { Accumulation Areas (WAAs) }\end{array}$ & $\begin{array}{ll}\text { Am- } 253 \\
\text { Bi-207 }\end{array}$ & $\begin{array}{l}\frac{1.5 E-11}{8.5 E-13} \\
\end{array}$ & \begin{tabular}{|l|l}
$1.0 \mathrm{E}-\mathrm{-}-03$ \\
1.03
\end{tabular} & & & & & & $\begin{array}{l}1.5-14 \\
8.5-16\end{array}$ & & & & & & & \\
\hline & & & & $\frac{c-14}{\text { Ce-144 }}$ & $\begin{array}{l}\frac{1.2 \mathrm{E}-09}{1.2 \mathrm{E}-10} \\
-\end{array}$ & $\begin{array}{l}1.0 \mathrm{E}-\mathrm{-}-3 \\
1.0 \mathrm{E}-3\end{array}$ & & & & & & $\frac{1.2 E-12}{1.2 E-13}$ & & & & & & & \\
\hline & & & & $\begin{array}{cc}0 .-57 \\
C 0.60\end{array}$ & 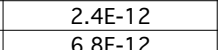 & $\begin{array}{l}1.0 \mathrm{E}-03 \\
10 \mathrm{E}-03\end{array}$ & & & & & & $\begin{array}{l}2.4 E-15 \\
68 E-15 \\
85-15\end{array}$ & & & & & & & \\
\hline & & & & Cs-134 & $4.8 \mathrm{E}-11$ & $\begin{array}{ll}1.0 \mathrm{E}-03 \\
\end{array}$ & & & & & & $4.8 E-14$ & & & & & & & \\
\hline & & & & $\begin{array}{l}\text { Cs-1-177 } \\
\text { Eu-152 }\end{array}$ & $\begin{array}{l}3.0 \mathrm{E}-10 \\
4.9 \mathrm{E}-11\end{array}$ & \begin{tabular}{|l|l|}
$.0 \mathrm{E}-03$ \\
$1.0 \mathrm{E}-03$
\end{tabular} & & 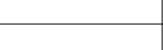 & & & & $\begin{array}{l}3.0 E-13 \\
4.9-14\end{array}$ & & & & & & & \\
\hline & & & & Eu-154 & 4.96-11 & $1.0 \mathrm{E}-03$ & & & & & & 4.9E-14 & & & & & & & \\
\hline & & & & $\frac{\mathrm{Eu}-155}{\mathrm{H}-3}$ & $\begin{array}{r}3.6-6-12 \\
1.0 E-05 \\
\end{array}$ & $\begin{array}{l}1.0 \mathrm{E}-03 \\
1.0 \mathrm{E}-03 \\
\end{array}$ & & & & & & 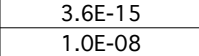 & & & & & & & \\
\hline & & & & $\frac{K-40}{M n-54}$ & $\begin{array}{l}3.3 E-11 \\
2.3 E-12\end{array}$ & $\begin{array}{ll}1.0 \mathrm{E}-03 \\
1.0 \mathrm{E}-03 \\
\end{array}$ & & & & & & $\begin{array}{l}3.3 E-14 \\
2.3-15 \\
\end{array}$ & & & & & & & \\
\hline & & & & Nb-95 & $\frac{1.26-12}{9.55-11}$ & $\begin{array}{l}1.0 E-03 \\
100-03\end{array}$ & & & & & & 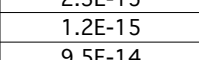 & & & & & & & \\
\hline & & & & $\begin{array}{lll}\mathrm{NN}-239 \\
\mathrm{No} 239\end{array}$ & $\frac{2.5-12}{2.55-12}$ & $\begin{array}{l}1.0 \mathrm{E}-03 \\
1.03 \\
\end{array}$ & & & & & & $20.5-15$ & & & & & & & \\
\hline & & & & 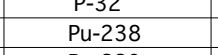 & $\frac{1.4-0.7}{1.11-12}$ & \begin{tabular}{|l|l|l}
$.0 E-03$ \\
$1.0 E-03$ \\
\end{tabular} & & & & & & $\begin{array}{l}\frac{1.4 \mathrm{E}-10}{1.1 \mathrm{E}-15}-15 \\
\end{array}$ & & & & & & & \\
\hline & & & & $\begin{array}{l}\text { Put2399 } \\
\text { Pu-240 }\end{array}$ & $\begin{array}{r}1.4 .4-10 \\
9.5 E-12 \\
\end{array}$ & $\begin{array}{l}1.0 \mathrm{E}-03 \\
1.0 \mathrm{E}-03 \\
\end{array}$ & & & & & & $\begin{array}{l}1.4 E-13 \\
9.5 E-15\end{array}$ & & & & & & & \\
\hline & & & & $\begin{array}{l}\text { Pu-241 } \\
\text { Put-242 }\end{array}$ & $\begin{array}{l}3.1 \mathrm{E}-10 \\
4.8 \mathrm{E}-11\end{array}$ & $\begin{array}{c}1.0 \mathrm{E}-03 \\
1.0 \mathrm{E}-03 \\
\end{array}$ & & & & & & $\begin{array}{l}3.1 \mathrm{E}-13 \\
4.8 \mathrm{E}-14\end{array}$ & & & & & & & \\
\hline & & & & Ra-226 & $1.11 E-12$ & $1.0 \mathrm{E}-03$ & & & & & & $1.1 \mathrm{E}-15$ & & & & & & & \\
\hline & & & & $\frac{S b-125}{S r-90}$ & $\begin{array}{l}3.6-6-12 \\
1.4 E-13 \\
-13\end{array}$ & \begin{tabular}{|c|}
$.0 \mathrm{E}-03$ \\
$1.0 \mathrm{E}-03$
\end{tabular} & & & & & & $\begin{array}{l}3.6 \mathrm{E}-15 \\
1.4 \mathrm{E}-16\end{array}$ & & & & & & & \\
\hline & & & & $\begin{array}{lc}\text { Tc-99 } \\
\text { Th } 2200\end{array}$ & 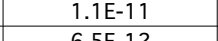 & $\begin{array}{l}1.0 \mathrm{OE}-03 \\
0.32\end{array}$ & & & & & & 1.11E-14 & & & & & & & \\
\hline & & & & Th-238 & $\frac{6.55-12}{5.5 E-14}$ & \begin{tabular}{|l|l}
$.0 \mathrm{E}-03$ \\
$1.0 \mathrm{E}-03$
\end{tabular} & & - & & & & $\begin{array}{l}6.5 E-15 \\
5.5 E-17\end{array}$ & & & & & & & \\
\hline & & & & Th-232 & $1.0 E-12$ & $1.0 \mathrm{E}-03$ & & & & & & $\frac{1.0 E-15}{1.75}$ & & & & & & & \\
\hline & & & & $\frac{U-234}{U-235}$ & $\begin{array}{l}1 . \mathrm{LI}-\mathrm{-}-\mathrm{8} \\
2.3 \mathrm{E}-09\end{array}$ & \begin{tabular}{c|c|}
$1.0 \mathrm{E}-03$ \\
$1.0 \mathrm{E}-03$
\end{tabular} & & & & & & 2...EE-11 2 & & & & & & & \\
\hline & & & & $\mathrm{u}-238$ & $1.7 \mathrm{E}-07$ & $1.0 \mathrm{E}-03$ & & & & & & $1.7 \mathrm{E}-10$ & & & & & & & \\
\hline 612 & Yard & Area Source & Repackaging operation & Am-241 & $1.9 E-08$ & $1.0 E-06$ & $\mathrm{NA}$ & NA & $\mathrm{NA}$ & None & 1 & $1.9 E-14$ & 444 & NE & $1.5 \mathrm{E}-10$ & 295 & ENE & $2.6 E-10$ & 5 \\
\hline & & & & $\frac{\mathrm{Bar}-133}{\mathrm{C}-14}$ & $\begin{array}{l}4.6 \mathrm{E}-\mathrm{C}-\mathrm{O} \\
3.3 \mathrm{E}\end{array}$ & \begin{tabular}{|c|}
$.0 E-06$ \\
$1.0 \mathrm{E}-06$
\end{tabular} & & & & & & $\begin{array}{l}4.6 E-16 \\
3.3 E-14\end{array}$ & & & & & & & \\
\hline & & & & Ce-144 & $7.36-09$ & $1.0 \mathrm{E}-06$ & & & & & & $7.3 E-15$ & & & & & & & \\
\hline & & & & $\frac{\mathrm{cm}-2-23}{\mathrm{Cm}-245}$ & $\frac{9.2-2-10}{5.7 E-10}$ & \begin{tabular}{c|c|}
$.0 \mathrm{E}-06$ \\
$1.0 \mathrm{E}-06$
\end{tabular} & & & & & & $\begin{array}{l}9.2 E-16 \\
5.7 E-16\end{array}$ & & & & & & & \\
\hline & & & & 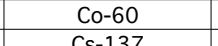 & 1.1E-10 & $1.0 \mathrm{E}-06$ & & & & & & 1.1.1E-16 & & & & & & & \\
\hline & & & & $\frac{\mathrm{Cs}-13 \mathrm{~T}}{\mathrm{H}-3}$ & $\begin{array}{l}4.4-05-09 \\
1.95-07\end{array}$ & \begin{tabular}{c|c|}
$.0 \mathrm{E}-06$ \\
$1.0 \mathrm{E}-06$
\end{tabular} & & & & & & $\begin{array}{l}4.4 E-15 \\
1.9-13\end{array}$ & & & & & & & \\
\hline & & & & $K-40$ & $\begin{array}{l}4.6 E-10 \\
.2509\end{array}$ & $1.0 \mathrm{E}-06$ & & & & & & 4.6E-16 & & & & & & & \\
\hline & & & & $\begin{array}{l}\text { Pu-c230 } \\
\text { Pu-239 }\end{array}$ & $\begin{array}{l}1.3 E-09 \\
9.7 E-09\end{array}$ & \begin{tabular}{|l|l|}
$1.0 E-06$ \\
1.06
\end{tabular} & & & & & & $\begin{array}{l}1.3-15 \\
9.7 E-15 \\
9\end{array}$ & & & & & & & \\
\hline & & & & $\begin{array}{l}\text { Rat-2226 } \\
\text { Th-232 }\end{array}$ & $\begin{array}{l}4.9 E-10 \\
1.6 E-09\end{array}$ & $\begin{array}{l}1.0 \mathrm{E}-06 \\
1.0 \mathrm{E}-06 \\
\end{array}$ & & & & & & $\begin{array}{l}4.9 \mathrm{E}-16 \\
1.6 \mathrm{E}-15\end{array}$ & & & & & & & \\
\hline & & & & $U-233$ & 9.5E-10 & $1.0 \mathrm{E}-06$ & & & & & & 9.5E-16 & & & & & & & \\
\hline & & & & $\frac{0-234}{u-325}$ & $\begin{array}{l}2.0 E=08 \\
20-0.09\end{array}$ & $1.00-00$ & & & & & & $\begin{array}{l}2.0 E-14 \\
2.0 E-15 \\
-15\end{array}$ & & & & & & & \\
\hline & & & & $\mathrm{U}-238$ & $4.0 E-08$ & $1.0 \mathrm{E}-06$ & & & & & & $4.0 \mathrm{E}-14$ & & & & & & & \\
\hline 614 & Open Area & Area source & Repackaging of waste & $H-3$ & $4.7 E-03$ & $1.0 \mathrm{E}-03$ & $\mathrm{NA}$ & NA & NA & None & 1 & 4.7E-06 & 420 & NNE & $2.9 \mathrm{E}-07$ & 253 & ENE & $6.5 \mathrm{E}-07$ & 5 \\
\hline & & & liquid scintillation cocktail & $C-14$ & 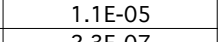 & $1.0 E-03$ & & & & & & $1.1 \mathrm{E}-08$ & & & & & & & \\
\hline & & & & $\begin{array}{l}5-35 \\
\text { Se-75 }\end{array}$ & $\begin{array}{l}2.3 E-07 \\
2.3 E-07\end{array}$ & \begin{tabular}{|l|l}
$1.0 \mathrm{E}-\mathrm{-}-03$ \\
\end{tabular} & & & & & & 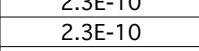 & & & & & & & \\
\hline & & & & Th-232 & $\begin{array}{l}9.1 E-09 \\
46-509\end{array}$ & $1.0 \mathrm{E}-03$ & & & & & & $\begin{array}{l}9.1 E-12 \\
46-12\end{array}$ & & & & & & & \\
\hline & & & & $\frac{1}{\text { Pu-238 }}$ & $\frac{1.26-08}{2.25}$ & $\frac{1.0 \mathrm{E}-03}{1.03}$ & & & & & & $\frac{2.2 \mathrm{E}-1}{2.1}-10$ & & & & & & & \\
\hline & & & & Pu-239 & $1.8 E-12$ & $1.0 \mathrm{E}-03$ & & & & & & $1.8 \mathrm{E}-\mathrm{x}$ & & & & & & & \\
\hline & & & & Pu-240 & $1.8 E-10$ & 1.0E-03 & & & & & & $1.8 E-13$ & & & & & & & \\
\hline & & & & Pu- & 4.1.E- -08 & $1.0 \mathrm{OE}-03$ & & & & & & 4.1E-11 411 & & & & & & & \\
\hline & & & & $\frac{P u-242}{U-234}$ & $\begin{array}{l}\frac{9.5 E-08}{2.3 E-09} \\
2 E\end{array}$ & $\frac{1.0 E-03}{1.0-03}$ & & & & & & 法 & & & & & & & \\
\hline & & & & 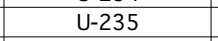 & $1.0 \mathrm{E}-10$ & $1.0 \mathrm{E}-03$ & & & & & & $1.0 \mathrm{E}-13$ & & & & & & & \\
\hline & & & & $0-238$ & $2.2 E=-09$ & $1.0 \mathrm{E}-03$ & & & & & & $2.2 E-12$ & & & & & & & \\
\hline
\end{tabular}


Attachment 1 - 2002 LLNL NESHAPs Annual Report Spreadsheet

\begin{tabular}{|c|c|c|c|c|c|c|c|c|c|c|c|c|c|c|c|c|c|c|c|}
\hline Building & Room/Area & Stack ID & Operation & Radionuclides & \begin{tabular}{|l} 
Annual Inventory \\
\end{tabular} & $\begin{array}{l}\text { Physical } \\
\text { Poisa }\end{array}$ & Stack & Stack & Stack & Control & Control Device & Estimated & $10 \mathrm{mrem} / \mathrm{y}$ & Site-Wide De & Dose Requirement & $0.1 \mathrm{mrem}$ & /y Monitoring & Requirement & Source \\
\hline & & & & & $\begin{array}{l}\text { with Potential for } \\
\text { Release (Ci) }\end{array}$ & $\begin{array}{l}\text { State } \\
\text { Factor }\end{array}$ & & $\frac{D_{\text {Dimeter }}}{(m)}$ & $\frac{V \text { Velocity }}{(m / s)}$ & Device(s) & $\begin{array}{l}\text { Abatement } \\
\text { Factor } \\
\end{array}$ & $\begin{array}{l}\text { Annual Emissions } \\
\text { (ci) }\end{array}$ & \begin{tabular}{|l|} 
Distance to \\
SWMME (m) \\
\end{tabular} & \begin{tabular}{|l|l} 
Direction \\
to SWMEI
\end{tabular} & $\begin{array}{cc}\text { EDE } \\
\text { (mrem) }\end{array}$ & $\begin{array}{l}\frac{\text { Distance }}{\text { to }} \text { tol (m) } \\
\end{array}$ & \begin{tabular}{|l} 
Direction \\
to MEI
\end{tabular} & $\begin{array}{l}\text { Unabated } \\
\text { EDE (mrem) }\end{array}$ & Category \\
\hline e South & east Quadrant of th & he Livermore Site has slightly elev & ated levels of Pu-239 in the surface s & Soil and air (presumab & Iy from resuspension & ). The sourc & of the Pu-239 & was past waste & management oper & erations. & & & & & & & & & \\
\hline Southeast & Quadrant & Area Source & Resuspension & Pu-239 & $\mathrm{NA}$ & $\mathrm{NA}$ & $\mathrm{NA}$ & $\mathrm{NA}$ & $\mathrm{NA}$ & None & 1 & $N A$ & 0 & $N A$ & $4.7 E-04$ & NA & NA & NA & 6 \\
\hline ITE 300 & DIFFUSE SOURCES & & & & & & & & & & & & & & & & & & \\
\hline Diffuse so & urces consist of res & suspension of depleted uranium a & nd waste handling & & & & & & & & & & & & & & & & \\
\hline Site 300 & (2) & (n) & $x^{2}+2 x$ & & & & & 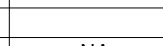 & E & $=3$ & & & & & & & & & \\
\hline & All & Area source & Soil resuspension & $\begin{array}{l}\mathrm{U}-238 \\
\mathrm{U}-235 \\
\end{array}$ & $\frac{N A}{N A}$ & $\mathrm{NA}$ & $N A$ & NA & NA & None & 1 & $\frac{N A}{N A}$ & NA & $N A$ & 3.3E-03 203 & NA & NA & $N_{A}$ & 6 \\
\hline & & & & U-234 & $\mathrm{NA}$ & NA & & & & & & NA & $x^{2}$ & & & & 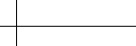 & & \\
\hline 804 & Open Area & Area Source & Low-level waste staging area & $\frac{H-3}{H}$ & NA & NA & NA & NA & NA & None & 1 & $\begin{array}{l}3.9 E-04 \\
551-08\end{array}$ & 4508 & $\mathrm{~s}$ & $2.1 E-07$ & 828 & $\mathrm{~N}$ & $4.5 E-06$ & 6 \\
\hline & 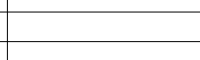 & & & $\begin{array}{l}\mathrm{u}-235 \\
1 \mathrm{H}-234 \\
\end{array}$ & NA & $\frac{\mathrm{NA}}{\mathrm{NA}}$ & - & & & & & $\begin{array}{l}3.15-10 \\
6.5-10 \\
315-09\end{array}$ & & & & & & & \\
\hline & & & & & & & & & & & & & & & & & & & \\
\hline EMISSION & SOURCES THAT AC & CCOUNT FOR MORE THAN 90\% O & F THE POTENTIAL EFFECTIVE DOSE & EQUIVALENT AT EAC: & H. SITE. & 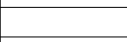 & & & & & & & 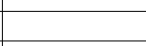 & 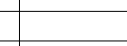 & & 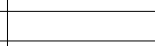 & & & 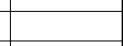 \\
\hline LIVERMOR & IE SITE SOURCES & & & & & $x_{0}$ & & & & & & & & 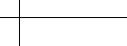 & & 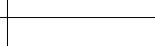 & & & 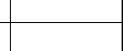 \\
\hline 612 & Yard & Area Source & Storage of low level waste & $\mathrm{H}-3$ & $\mathrm{NA}$ & NA & $\mathrm{NA}$ & $\mathrm{NA}$ & $\mathrm{NA}$ & None & 1 & $2.3 E+00$ & 444 & NE & $1.11 E-02$ & 276 & sw & $2.4 E-02$ & 6 \\
\hline 331 & $A \|^{* *}$ & $\begin{array}{l}\text { Stack } 1 \\
\text { Stack 2 }\end{array}$ & $\begin{array}{l}\text { Tritium research and development } \\
\text { Decontamination of parts }\end{array}$ & $\begin{array}{l}H-3 \\
H-3\end{array}$ & * & $\frac{1}{1}$ & $\begin{array}{l}30 \\
30\end{array}$ & $\frac{1.22}{1.22}$ & $\begin{array}{l}7.59 \\
10.5\end{array}$ & $\begin{array}{l}\text { None } \\
\text { None }\end{array}$ & $\frac{1}{1}$ & $\begin{array}{l}2.5 \mathrm{E}-02 \\
3.6+01\end{array}$ & 957 & ENE & $\begin{array}{l}8.1 \mathrm{E}-03 \\
\star \star \star 5.6 \mathrm{E}-03\end{array}$ & 957 & ENE & $\begin{array}{l}8.1 \mathrm{E}-03 \\
* * 5-6 \mathrm{E}-03\end{array}$ & 3 \\
\hline 514 & Evaporator & Room Air & Waste consolidation & Various nuclides & $4.5 E-05$ & $1.0 \mathrm{E}-03$ & $\mathrm{NA}$ & $N A$ & $\mathrm{NA}$ & None & 1 & $4.5 E-08$ & 528 & $\mathrm{NE}$ & $1.2 \mathrm{E}-03$ & 217 & sw & $3.1 \mathrm{E}-03$ & 1 \\
\hline 612 & 102 & Room Air & Laboratory analysis & \begin{tabular}{|l} 
Various nuclides \\
\end{tabular} & $4.2 E-05$ & $1.0 \mathrm{E}-03$ & NA & $\mathrm{NA}$ & $\mathrm{NA}$ & None & 1 & $4.2 \mathrm{E}-08$ & 444 & NE & $1.1 E-03$ & 295 & ENE & $1.5 \mathrm{E}-03$ & 1 \\
\hline 331 & Outside & None & Storage of contaminated parts & $\mathrm{H}-3$ & NA & 1 & NA & $\mathrm{NA}$ & NA & None & 1 & 1 & 957 & ENE & $8.7 \mathrm{E}-04$ & 441 & ssw & 0.0026 & 6 \\
\hline SITE 300 & SOUPCES & & & & & & & & & & & & & & & & & & \\
\hline 851 & Eiring Table & None & Fynlosive testc & & $1.5 \mathrm{E}-02$ & 1 & $N A$ & $N A$ & $N A$ & None & 1 & $15=-0^{2}$ & 3170 & SSE & $18 E^{2} \mathrm{C}^{2}$ & 1396 & waw & $200025)$ & 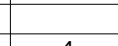 \\
\hline & rining lave & None & Explosive tests & 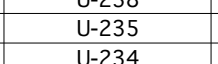 & $\begin{array}{ll}2.06-04 \\
1.0-0.03 \\
\end{array}$ & 1 & & $T_{N A}$ & & None & & $\begin{array}{l}1.16-04 \\
3.1 .04 \\
2.3 E-03\end{array}$ & 3170 & SSE & $1.8 E-02$ & 1396 & Wow & $2.0 E-02$ & 4 \\
\hline Site 300 & All & Area Source & Soil resuspension & $u-238$ & $\mathrm{NA}$ & NA & NA & $\mathrm{NA}$ & $\mathrm{NA}$ & None & 1 & $\mathrm{NA}$ & NA & NA & $3.3 E-03$ & NA & NA & NA & 6 \\
\hline & & & & $\begin{array}{l}\mathrm{U}-253 \\
\mathrm{U}-234\end{array}$ & NA & $\frac{\mathrm{NA}}{\mathrm{NA}}$ & & & & & & $N A$ & & & & & & & \\
\hline
\end{tabular}


LLNL NESHAPs Report 2002

\section{ATTACHMENT 2. Surrogate Radionuclides List}

The need for selection of a surrogate isotope occurs when an isotope used in operations (isotope of interest) is not contained in the limited nuclide library in the NESHAPs dose compliance model CAP88-PC. The selection of a suitable surrogate is based upon several criteria. If possible, a surrogate isotope is chosen from the CAP88-PC radionuclide library that has a metabolically similar behavior to the isotope of interest. Following an acute inhalation exposure, the metabolically similar surrogate would concentrate in the same specific organs and tissues as the isotope of interest. In most cases the surrogate selected possesses similar modes of decay and decay energies of the radiation type of the isotope of interest. Thus, the surrogate models the behavior of the isotope with similar relative biological effect due to deposition energy.

According to present knowledge, the daughter nuclides produced following physical decay are assumed to remain organ site specific and follow the translocation pathway of the parent. Therefore, when a surrogate of similar metabolic behavior is not available or has a greatly dissimilar half-life, the surrogate chosen is a daughter nuclide of the isotope of interest that will remain organ site specific and follow the translocation pathway of the parent.

Once a surrogate has been selected, the equivalent source term is adjusted by the product of the initial inventory of the isotope of interest and the ratio of the effective dose equivalent of the surrogate to that of the isotope of interest. For determining the dose ratio, the primary exposure pathway is assumed to be that of inhalation and inhalation dose conversion factors (International Commission on Radiological Protection Publication No. 71, "Age-dependent Doses to Members of the Public from Intake of Radionuclides: Part 4 Inhalation Dose Coefficients," Elsevier Science Ltd., 1996) are used for determination of the effective dose equivalents.

In addition, isotopic analysis of mixtures of radionuclides are not always available, and radionuclide usage inventories are stated as "gross alpha," "gross beta," "gross gamma," or "mixed fission products" (MFP). In these cases, ${ }^{239} \mathrm{Pu}$ is used as the surrogate for gross alpha, ${ }^{137} \mathrm{Cs}$ is used as the surrogate for gross gamma, and ${ }^{90} \mathrm{Sr}$ is used as the surrogate for gross beta and mixed fission products to provide conservative dose estimates.

Table 2-1 provides a list of radionuclides not in the CAP88-PC library and their respective surrogates. 
LLNL NESHAPs Report 2002

Table 2-1. List of surrogate radionuclides.

\begin{tabular}{|c|c|c|c|c|c|c|c|c|c|}
\hline Isotope & $\begin{array}{c}\text { Half- } \\
\text { Life }\end{array}$ & $\begin{array}{c}\text { Lung } \\
\text { Class }^{a}\end{array}$ & $\begin{array}{c}\text { ALI (inh) } \\
\qquad \mu \mathrm{Ci}\end{array}$ & $\begin{array}{c}\text { DAC (inh) } \\
\mu \mathrm{Ci} / \mathrm{m}^{3}\end{array}$ & Surrogate & $\begin{array}{c}\text { Half- } \\
\text { Life }\end{array}$ & $\begin{array}{c}\text { Lung } \\
\text { Class }^{a}\end{array}$ & $\begin{array}{c}\text { ALI (inh) } \\
\mu \mathrm{Ci}\end{array}$ & $\begin{array}{c}\text { DAC (inh) } \\
\mu \mathrm{Ci} / \mathrm{m}^{3}\end{array}$ \\
\hline Ca-108m & n $127 \mathrm{y}$ & $\mathrm{Y}$ & $2.0 \square 10^{1}$ & $1.0 \square 10^{-8}$ & Co-60 & $5.271 \mathrm{y}$ & Y & $3.0 \square 10^{1}$ & $1.0 \square 10^{-8}$ \\
\hline Bi-207 & $38 \mathrm{y}$ & W & $4.0 \square 10^{2}$ & $1.0 \square 10^{-7}$ & Bi-214 & $19.9 \mathrm{~min}$ & W & $9.0 \square 10^{2}$ & $4.0 \square 10^{-7}$ \\
\hline Ca-45 & $163 d$ & $\mathrm{~W}$ & $8.0 \square 10^{2}$ & $4.0 \square 10^{-7}$ & Sr-90 & $29.12 y$ & $\mathrm{D}$ & $2.0 \square 10^{1}$ & $8.0 \square 10^{-9}$ \\
\hline Cd-109 & $464 \mathrm{~d}$ & $\mathrm{Y}$ & $1.0 \square 10^{2}$ & $5.0 \square 10^{-8}$ & Co-60 & $5.271 \mathrm{y}$ & $\mathrm{Y}$ & $3.0 \square 10^{1}$ & $1.0 \square 10^{-8}$ \\
\hline Cf-249 & $350.6 \mathrm{y}$ & $Y$ & $1.0 \square 10^{-2}$ & $4.0 \square 10^{-12}$ & $\mathrm{Cm}-245$ & $8500 \mathrm{y}$ & W & $6.0 \square 10^{-3}$ & $3.0 \square 10-12$ \\
\hline Cf-250 & $13.1 \mathrm{y}$ & W & $9.0 \square 10^{-3}$ & $4.0 \square 10-12$ & Am-241 & $432.2 \mathrm{y}$ & W & $6.0 \square 10^{-3}$ & $3.0 \square 10-12$ \\
\hline $\mathrm{Cl}-36$ & $3.01 \square 10^{5} \mathrm{y}$ & y $W$ & $2.0 \square 10^{2}$ & $1.0 \square 10^{-7}$ & Cs-137 & $30 \mathrm{y}$ & $\mathrm{D}$ & $2.0 \square 10^{2}$ & $6.0 \square 10-8$ \\
\hline Es-254 & $275.7 \mathrm{~d}$ & W & $7.0 \square 10^{-2}$ & $3.0 \square 10^{-11}$ & Pu-239 & $24065 \mathrm{y}$ & $\mathrm{Y}$ & $2.0 \square 10^{-2}$ & $7.0 \square 10-12$ \\
\hline Eu-149 & $93.1 \mathrm{~d}$ & $\mathrm{~W}$ & $3.0 \square 10^{3}$ & $1.0 \square 10-6$ & Pm-151 & $28.4 \mathrm{hr}$ & $\mathrm{Y}$ & $3.0 \square 10^{3}$ & $1.0 \square 10^{-6}$ \\
\hline Gd-148 & $93 \mathrm{y}$ & $\mathrm{D}$ & $8.0 \square 10^{-3}$ & $3.0 \square 10-12$ & La-140 & $40.272 \mathrm{~h}$ & W & $1.0 \square 10^{3}$ & $5.0 \square 10^{-7}$ \\
\hline Os-185 & $94 \mathrm{~d}$ & $\mathrm{D}$ & $5.0 \square 10^{2}$ & $2.0 \square 10^{-7}$ & Mo-99 & $66 \mathrm{~h}$ & $\mathrm{Y}$ & $1.0 \square 10^{3}$ & $6.0 \square 10^{-7}$ \\
\hline P-33 & $25.4 \mathrm{~d}$ & $\mathrm{~W}$ & $3.0 \square 10^{3}$ & $1.0 \square 10^{-6}$ & P-32 & $14.29 \mathrm{~d}$ & $\mathrm{D}$ & $9.0 \square 10^{2}$ & $4.0 \square 10^{-7}$ \\
\hline $\operatorname{Re}-184$ & $38 \mathrm{~d}$ & W & $1.0 \square 10^{3}$ & $6.0 \square 10^{-7}$ & Mo-99 & $66 \mathrm{~h}$ & $\mathrm{Y}$ & $1.0 \square 10^{3}$ & $6.0 \square 10^{-7}$ \\
\hline Se-75 & $119.8 \mathrm{~d}$ & $\mathrm{~W}$ & $6.0 \square 10^{2}$ & $3.0 \square 10^{-7}$ & As-76 & $26.32 \mathrm{~h}$ & W & $1.0 \square 10^{3}$ & $6.0 \square 10^{-7}$ \\
\hline Sr-85 & $64.8 \mathrm{~d}$ & $\mathrm{D}$ & $3.0 \square 10^{3}$ & $1.0 \square 10^{-6}$ & Sr-90 & $29.12 \mathrm{y}$ & $\mathrm{D}$ & $2.0 \square 10^{1}$ & $8.0 \square 10^{-9}$ \\
\hline Ta-182 & $115 d$ & $\mathrm{Y}$ & $1.0 \square 10^{2}$ & $6.0 \square 10^{-8}$ & Hf-181 & $42.4 \mathrm{~d}$ & $\mathrm{~W}$ & $4.0 \square 10^{2}$ & $2.0 \square 10^{-7}$ \\
\hline Tb-157 & $110 y$ & $\mathrm{~W}$ & $3.0 \square 10^{2}$ & $1.0 \square 10^{-7}$ & La-140 & $40.272 \mathrm{~h}$ & W & $1.0 \square 10^{3}$ & $5.0 \square 10^{-7}$ \\
\hline Tb-158 & $180 \mathrm{y}$ & $\mathrm{W}$ & $2.0 \square 10^{1}$ & $8.0 \square 10^{-9}$ & La-140 & $40.272 \mathrm{~h}$ & W & $1.0 \square 10^{3}$ & $5.0 \square 10^{-7}$ \\
\hline T1-204 & $3.78 \mathrm{y}$ & $\mathrm{D}$ & $2.0 \square 10^{3}$ & $9.0 \square 10^{-7}$ & $\mathrm{~Pb}-214$ & $26.8 \mathrm{~min}$ & $\mathrm{D}$ & $8.0 \square 10^{2}$ & $3.0 \square 10^{-7}$ \\
\hline Tm-168 & $93.1 \mathrm{~d}$ & $\mathrm{~W}$ & $2.0 \square 10^{3}$ & $8.0 \square 10^{-7}$ & La-140 & $40.272 \mathrm{~h}$ & W & $1.0 \square 10^{3}$ & $5.0 \square 10-7$ \\
\hline Tm-171 & $1.92 \mathrm{y}$ & $\mathrm{Y}$ & $3.0 \square 10^{2}$ & $1.0 \square 10^{-7}$ & La-140 & $40.272 \mathrm{~h}$ & W & $1.0 \square 10^{3}$ & $5.0 \square 10^{-7}$ \\
\hline Y-88 & $106.64 \mathrm{~d}$ & $\mathrm{Y}$ & $2.0 \square 10^{2}$ & $1.0 \square 10^{-7}$ & Y-90 & $64 \mathrm{~h}$ & Y & $6.0 \square 10^{2}$ & $3.0 \square 10^{-7}$ \\
\hline Am-244 & $10.1 \mathrm{~h}$ & $\mathrm{~W}$ & $2.0 \square 10^{2}$ & $8.0 \square 10^{-8}$ & $\mathrm{Cm}-244$ & $18.11 \mathrm{y}$ & W & $1.0 \square 10^{-2}$ & $5.0 \square 10-12$ \\
\hline $\mathrm{Au}-195$ & $183 \mathrm{~d}$ & Y & $4.0 \square 10^{2}$ & $2.0 \square 10^{-7}$ & Вa-133 & $10.74 \mathrm{y}$ & $\mathrm{D}$ & $7.0 \square 10^{2}$ & $3.0 \square 10-7$ \\
\hline Co-56 & $78.76 \mathrm{~d}$ & Y & $2.0 \square 10^{2}$ & $8.0 \square 10^{-8}$ & Co-60 & $5.271 \mathrm{y}$ & Y & $3.0 \square 101$ & $1.0 \square 10^{-8}$ \\
\hline Gd-146 & $48.3 \mathrm{~d}$ & W & $3.0 \square 10^{2}$ & $1.0 \square 10^{-7}$ & \multicolumn{2}{|c|}{ Sm-147 1.06ロ1011 y } & W & $4.0 \square 10^{-2}$ & $2.0 \square 10-11$ \\
\hline Kr-85 & $10.72 \mathrm{y}$ & Gas & See Note & $1.0 \square 10^{-4}$ & & & & & \\
\hline Rh-102 & $2.9 \mathrm{y}$ & Y & $6.0 \square 10^{1}$ & $2.0 \square 10^{-8}$ & Rh-106m & $29.9 \mathrm{~s}$ & Y & $4.0 \square 10^{4}$ & $1.0 \square 10^{-5}$ \\
\hline U-239 & $23.54 \mathrm{~min}$ & $Y$ & $2.0 \square 10^{5}$ & $6.0 \square 10^{-5}$ & U-240 & $14.1 \mathrm{~h}$ & Y & $2.0 \square 10^{3}$ & $1.0 \square 10^{-6}$ \\
\hline $\mathrm{Zr}-90$ & $809 \mathrm{~ms}$ & $\mathrm{~W}$ & $\mathrm{~N} / \mathrm{A}$ & $\mathrm{N} / \mathrm{A}$ & Y-90 & $64 \mathrm{~h}$ & Y & $6.0 \square 10^{2}$ & $3.0 \square 10^{-7}$ \\
\hline Po-209b & $102 y$ & $\mathrm{~N} / \mathrm{A}$ & $\mathrm{N} / \mathrm{A}$ & $\mathrm{N} / \mathrm{A}$ & Pu-239 & $24065 \mathrm{y}$ & Y & $2.0 \square 10^{-2}$ & $7.0 \square 10-12$ \\
\hline
\end{tabular}

Note: The DAC for $\mathrm{Kr}-85$ also has been relaxed considerably since its beta emission only irradiates the skin. The DAC is based on limitation of non-stochastic effects in the skin; the MPC was derived assuming that the beta particles of energy greater than $0.1 \mathrm{MeV}$ contributed to the whole body dose.

a $\quad \mathrm{D}=$ days, $\mathrm{W}=$ weeks, $\mathrm{Y}=$ years.

b No ALI or DAC information available. Pu-239 used to provide a conservative alpha-emitter dose.

Source: Limiting Values of Radionuclide Intake and Air Concentration and Dose Conversion Factors for Inhalation, Submersion and Ingestion, Federal Guidance Report No. 11, EPA-520/1-88020, U.S. Đnvironmental Protection Agency, 1988. 
LLNL NESHAPs Report 2002

\title{
ATTACHMENT 3. Content and Outcome of Proposal to EPA for Use of Air Monitoring in Demonstrating NESHAPs Compliance for Minor Sources
}

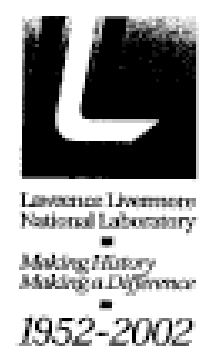

\author{
Environmental Protection Department \\ Operations and Regulatory Affairs Division
}

March 5, 2003

Jack Broadbent, Director

Air Division

U.S. Environmental Protection Agency, Region LX

75 Hawthome St.

San Francisco, CA 94105

Subject: Request for Authorization to Use Surveillance Monitoring to Demonstrate Radionuclide NESHAPs Compliance for Minor Emissions Points

Dear Mr. Broadbent:

Lawrence Livermore National Laboratory (LLNL) is a Department of Energy (DOE) research facility operated by University of California that is subject to requirements of the National Emission Standards for Hazardous Air Pollutants (NESHAPs) of the Clean Air Act, 40 Code of Federal Regulations (CFR) Part 61, Subpart H. LLNL currently demonstrates compliance for various categories of emission sources. These sources include major (continuously monitored) and minor point sources, (i.e, stacks), releases from explosives experiments conducted on open air firing tables, and diffuse area sources, such as contaminated sotls. LLNL currently complies with NESHAPs annual dose calculation and reporting requirements through dose estimates based on

(1) stack monitoring data for major (continuously monitored) point sources,

(2) inventory data/engineering calculations for minor emission point sources,

(3) inventory data and empirical scaling laws defining the size and height of explosive tests, and (4) ambient air monitoring or inventory data/engineering calculations for diffuse sources. By this letter, we are requesting authorization to use ambient air surveillance monitoring to demonstrate compliance with the dose assessment requirements of NESHAPs for the source estimates based on inventory data/engineering calculations, i.e., minor emission point sources, and diffuse sources not currently estimated from ambient air.

Several factors justify using air sampler measurements as an alternative method to demonstrate radionuclide NESHAPs compliance.

First, the NESHAPs regulation expressly grants EPA authority to permit compliance demonstration by environmental monitoring. 40 CFR 61.93(b)(5) allows the use of air samplers to obtain "environmental measurements of radionuclide air concentrations at critical receptor locations as an alternative to air dispersion calculations in demonstrating compliance" when the six criteria are established. The program we are proposing will meet the six criteria, which, along with LLNL's plan for meeting them, are submitted as an attachment to this letter. Moreover, the 1995 Memorandum of 
Understanding between the U.S. EPA and the US. DOE' conceming NESHAPs expressly states that the use of environmental measurements of radionuclides at critical receptor locations is "particularly appropriate ... for facilities with minor emission points (of the periodic confirmatory type) and/or diffuse sources as primary contributors to dose."

EPA has, in fact, granted facilities permission to demonstrate compliance with NESHAPs when the conditions in 40 CFR 61.93(b)(5) are met. The opinion allowing certain operations at the Oak Ridge National Laboratory has been documented on the EPA's web page on the Internet. ${ }^{2}$ The Fernald Environmental Management Program and the Mound Plant, with EPA concurrence, have also implemented a NESHAPs compliance demonstration program based on ambient air monitoring.

Secondly, monitoring data provide a better starting point for dose estimates. Air samplers can be placed at or near the location where an individual can be exposed, and air samplers provide measurements of the real concentrations at that location. In contrast, modeling results are estimates of the concentration averaged over an area specified by the model. Moreover, it is important to keep in mind that models are validated, ie, their accuracy determined, by comparison of modeled results with monitoring data. CAP88-PC, the EPA-approved model currently used to demonstrate NESHAPs compliance, was verified by comparing the environmental monitoring data at five sites with the model predictions. In net effect, the doses calculated for NESHAPs compliance provide a retrospective look at the actual effects of a facility. Monitoring data from continuous ambient air monitors are an excellent source of information about the actual concentrations of radionuclides in air. In fact, LLNL regularly includes in its annual NESHAPs reports a comparison of modeling and monitoring results for the principal emitted radionuclide, tritium, and the comparison shows that model results generally over predict air concentrations at the site perimeter.

Finally, LLNL has collected and measured very low levels of specific nuclides in the ambient air since 1971. Air samplers are currently in use to evaluate diffuse radionuclide emission sources at LLNL for which inventory data is unavailable. It is worthy of note that, for the years 2000 and 2001, diffuse sources (rather than continuously monitored major point sources) have been major contributors to dose at the LLNL Livermore site, accounting for more than one-half of the total dose calculated for the site, and that $40 \%$ or more of the total dose calculated for the Livermore site for those two years was based on ambient air measurements.

\footnotetext{
'Memorandum of Understhnding Between the U.S. Environmental Protection Agency and the U.5. Department of Energy concerning the Clean Air Act Fmission Standards for Radionuclides 40 CFR Part 61 including subparts H. ., Q \& T. Signed by the Environmental Protection Agency. September 29, 1994, and by the Department of Energy, April 5, 1995.

${ }^{2}$ Memoeandum, Frank Marcinowski Division Directoe, Radiation Protection Divisjon, Office of Radiation and Indoor Air, Envirunmental Protection Agency to Regional Radionuclide NESHAP8 Coordinaturs, Regions 1-X, "Criteria to Determine Whether a Leased Facility At DXE is Subject to Subpart $\mathrm{H}_{\text {, }}$ Jknuary 26, 2001 (Found at Applicability Determination Lndex, Determization Detai Control Number 2010004, htip://esdev sdc-moses.com/ocea/oc/adi/html/2010004.htm). TAMMU3-021
} 
40 CFR 61.93(b)(5) allows the use of air samplers to obtain "environmental measurements of radionuclide air concentrations at critical receptor locations as an alternative to air dispersion calculations in demonstrating compliance" when criteria are established. These criteria, a summary of how they will be met by LLNL, supporting LLNL procedures, as paper copy of the air surveillance monitoring chapter of the LLNL Environmental Report 2001, and a compact disk of the entire LLNL Environmental Report 2001 are submitted with this letter.

LLNL has demonstrated compliance with radionuclide NESHAPs since 1990. At all times, the doses from LLNL operations have been well below the 10 mrem standard. For the Livermore site, the doses have ranged from a high of $0.240 \mathrm{mrem}$ in 1990 to a low of 0.017 mrem reported for calendar year 2001. For Site 300 , the doses have ranged from a high of 0.081 mrem in 1994 to a low of $0.019 \mathrm{mrem}$ in 2000 . Approval of this application will allow LLNL to make stack monitoring of sources with a potential to emit greater than $10 \%$ of the standard the primary focus of its NESHAPS compliance efforts, rather than the current focus on collecting inventory data and modeling nearly 200 sources that account for less than $1 \%$ of the total dose consequences from LLNL operations.

We look forward to discussing with you in more detail how our existing monitoring program meets the requirements of 40 CFR 61.93(b)(5) for demonstrating compliance with NESHAPs for minor point sources. Please contact Art Biermann, $925422-8017$ for further information.

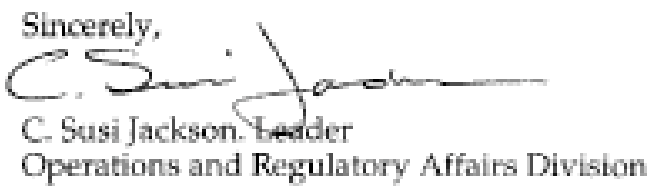

Attachments:

Six Criteria for Use of Environmental Measurements

Air Tritium Sampling Procedure

Air Particulate Sampling Procedure

Air Particulate Sampler Calibration Procedure

Air Surveillance Monitoring Chapter (SAER 2001)

Ambient Air Monitoring Chapter (SAER 2001)

SAER 2001 CD

$\mathrm{CC}:$

Biermann, A. L-629

Gallegos, G. L-629

Harrach, B. L-629

Lessler, $\mathbb{R}$. EPA IX

Mishra, V, DOE

Raber, E. L-626

Rauhut, K. L-701

Tripodes, J. L-626

DCC

TAMMOO-0Q1 


\section{Six Criteria for the Use of Environmental Measurements}

40 CFR 61.93(b)(5) allows the use of high-volume air samplers to obtain "environmental measurements of radionuclide air concentrations at critical receptor locations as an alternative to air dispersion calculations in demonstrating compliance" when the following six criteria are established:

(1) The air at the point of measurement [i.e., the location of the critical receptor| shall be continuously sampled for collection of radionuclides.

(2) Those radionuclides released from the facility that are the major contributors to the effective dose equivalent must be collected and measured as part of the envirormental measurement program.

(3) Radionuclide concentrations that would cause an effective dose equivalent of $10 \%$ of the standard shall be readily detectable and distinguishable from background.

(4) Net measured radionuclide concentrations shall be compared to the concentration levels in Table 2 appendix $\mathrm{E}$ of this part to determine compliance with the standard. In the case of multiple radionuclides being released from a facility, compliance shall be demonstrated if the value for all radionuclides is less than the concentration level in Table 2 of appendix $\mathrm{E}$ of this part, and the sum of the fractions that result when each measured concentration value is divided by the value in Table 2 of appendix E of this part for each radionuclide is less than 1.

(5) A quality assurance program shall be conducted that meets the performance requirements described in appendix B, Method 114 of this part.

(6) Use of environmental measurements to demonstrate compliance with the standard is subject to prior approval of EPA. Applications for approval shall include a detailed description of the sampling and analytical methodology and show how the above criteria will be met.

\section{Summary of LLNL's ability to meet the six criteria}

(1) Continuous sampling

LLNL currently maintains continuous samplers at perimeter and more distant locations, including the location of the site-wide maximally exposed individuals. If the location of the site-wide maximally exposed individual changes, due to a change in operations, or the addition of houses or businesses, samplers can be placed at or near the location, or at a fence line location that reasonably (yet conservatively) measures the concentrations at that location of potential exposure.

(2) Major contributors to dose

LLNL collects samples for tritium and plutonium at the Livermore site, and for tritium and uranium at Site 300 . The primary radionuclide emitted from point and diffuse sources at the Livermore site is tritium. Plutonium samples are collected to measure the contribution of the resuspension of contaminated soil in the southeast quadrant of the site. Uranium isotopes are not major contributors to dose at the Livermore site; however, they are the isotopes responsible for more than $90 \%$ of the calculated dose for Site 300 . Therefore, LCNL maintains a number of high-volume air-particulate samplers at Site 300.

TAMM03-021 
(3) Radionuclide detection

LLNL maintains a very sensitive air monitoring capability. No single nuclide contributes a dose that is more than $10 \%$ of the dose standard. Currently, doses from all nuclides combined are less than $1 \%$ of the standard. Detection limits for the analytical methods currently in place for tritium, plutonium and uranium are sufficiently sensitive to provide defections at this level. (Although uranium isotopes are not necessarily distinguishable from background, depending on the filter media, and analytical method, LLNL has recently reinstituted the collection of samples for uranium on cellulose filters, with analysis by mass spectrometry.)

(4) Radionuclide concentrattons

Radionuclide concentrations are far below the concentration levels of Table 2 appendix E, and, therefore, well below the NESHAPs standard. According to the "Background Information Document: Procedures for Demonstrating Compliance with 40 CFR Part 61, Subpart I, the values in the table are "the maximum ground-level air concentration that would not result in a dose exceeding the standard." (EPA 520/1-89-001, page 4-28.) In other words, concentrations below the levels of Table 2 would be proportionally lower than the NESHAPs standard. The measured concentrations in calendar year 2001 at the location of the sitewide maximally exposed individual at the Livermore site compared to the Table 2 appendix $E$ concentration levels are provided in Table 1. Note that for Site 300, the maximum monthly concentration of uranium-238 does not take into account the contribution of naturally occurring uranium in resuspended soil, also LLNL is implementing in 2002, a more sensitive method of determining the concentrations of uranium in air based on mass spectrometry rather than alpha spectrometry.

Table 1. Concentrations of nuclides of concem at the location of the maximally exposed individual (MEI) in calendar year 2001.

\begin{tabular}{|c|c|c|c|c|c|}
\hline Location & Nucitise & $\begin{array}{l}\text { Table } \\
\text { poncentration } \\
\text { standand }\end{array}$ & $\begin{array}{l}\text { Mosasured } \\
\text { concemtratian }\end{array}$ & $\begin{array}{l}\text { Messured } \\
\text { concantration } \\
\text { as a traction } \\
\text { of the } \\
\text { standard }\end{array}$ & $\begin{array}{l}\text { Delection Imit } \\
\text { (approximato) }\end{array}$ \\
\hline $\begin{array}{l}\text { Livermore site } \\
\text { MEI }\end{array}$ & TrĔLm & $1.5 \times 10^{9} \mathrm{Cum}^{3}$ & $2.6 \times 10^{-12} \mathrm{cim}^{3}$ & $2 \times 10^{3}$ & $1 \times 10^{-12} \operatorname{csm}^{3}$ \\
\hline $\begin{array}{l}\text { Livermere site } \\
\text { MEI }\end{array}$ & $\begin{array}{l}\text { Pliborium - } \\
23 \theta\end{array}$ & $2.0 \times 10^{-15} \mathrm{Cvm}^{3}$ & $1.2 \times 10^{18} \mathrm{csm}^{3}$ & $6 \times 10^{-4}$ & $3 \times 10^{-18} \mathrm{Cim}^{3}$ \\
\hline She $300 \mathrm{MEI}$ & Urarium -236 & $8.3 \times 1 \sigma^{-15} \mathrm{Cvm}^{3}$ & $24 \times 10^{-16} \mathrm{Cum}^{3}$ & $3 \times 10^{-2}$ & $2 \times 10^{-17} \mathrm{cim}^{3}$ \\
\hline
\end{tabular}

(5) QA Program

LLNL maintains an extensive QA program. The written procedures, instructions, and the site annual report chapters for calendar year 2001 that address environmental surveillance monitoring are provided as an attachment, and demonstrate compliance with this requirement.

(6) Prior Approval

This letter and attachments provide a detailed description of the sampling and analytical methodology and show how the preceding five criteria have been, and will be met. 


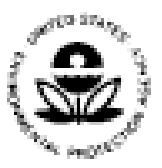

\section{UNITED STATES ENVIRONMENTAL PROTECTION AGENCY \\ AEGION IX \\ 75 Hawthome Streat \\ San Francisco, CA 94105-3901}

April 22, 2003

Ms. C. Susi Jackson, Leader

Operations and Regulatory Affairs Division

Lawrence Livermore National Laboratory

Environmental Protection Department, University of California

P.O. Box 808, Livermore, CA 94551-9900

Subject: Request for Authorization to Use Surveillance Monitoring to Demonstrate Radionuclide NESHAPs Compliance for Minor Emissions Points

Dear Ms. Jackson:

We have reviewed your letter and attachments of March 5, 2003 requesting approval to use surveillance monitoring for minor emission points. In accordance with the provisions of the Clean Air Act and 40 CFR Part 61, Subpart $\mathrm{H}$, your request has been approved.

We request that emissions be closely monitored, identified, and quantified during the use of the approved altemative method, and that the monitoring procedure and related data be kept on file for review by EPA.

This alternative method may be used immediately after this approval is received by the Lawrence Livermore National Laboratory.

If you have any questions, please contact Dick Lessler, at (415) 947-4197

Sincerely,

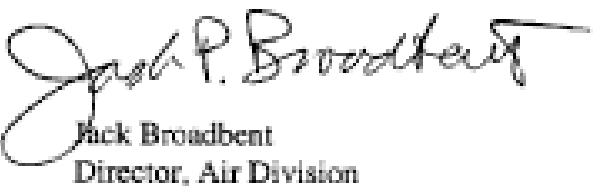

